Latvijas Valsts mežzinātnes institūts "Silava"

Latvijas Lauksaimniecības universitāte

Meža fakultāte

Mežkopības katedra

Mg. silv. Jānis Liepiṇš

promocijas darbs

\title{
KOKAUDŽU BIOMASAS NOTEIKŠANAS METODIKAS IZSTRĀDE UN OGLEKL,A UZKRĀJUMA APRĒĶINI LATVIJĀ \\ METHODOLOGY DEVELOPMENT FOR FOREST STAND BIOMASS AND CARBON STOCK ESTIMATES IN LATVIA
}

mežzinātņu doktora (Dr.silv.) zinātniskā grāda iegūšanai

Mežzinātnes nozares meža ekologiijas un mežkopības apakšnozarē

Promocijas darba vadītājs

amats Dr. silv. Kaspars Liepiņš

Promocijas darba vadītājs

amats Dr. silv. Andis Lazdiñ̌s

Promocijas darba autors

Salaspils 


\section{ANOTĀCIJA}

Kokaudžu biomasas noteikšanas metodikas izstrāde un oglekḷa uzkrājuma aprēķini Latvijā. LVMI "Silava” un LLU, 2019. Liepiṇš J., zinātniskie vadītāji: Dr. silv. Kaspars Liepiņš un Dr. silv. Andis Lazdiņš. Promocijas darba apjoms: 105 lpp., 14 tabulas, 31 attēls un 268 literatūras avoti. Promocijas darbs izstrādāts Latvijas Valsts mežzinātnes institūtā "Silava", doktorantūras studijas Latvijas Lauksaimniecības universitātes Meža fakultātē laika periodā no 2014. līdz 2019. gadam.

Pētījuma aktualitāti nosaka starptautiskās saistības, ko Latvija apṇēmusies pildīt, ratificējot Apvienoto Nāciju Organizācijas Vispārējo konvencija par klimata pārmaiņām (UNFCCC), tās Kioto protokolu un Parīzes vienošanos. Atbilstoši UNFCCC prasībām, Latvijai katru gadu ir jāsagatavo pārskats par siltumnīcefekta gāzu (SEG) emisijām un oglekḷa dioksīda $\left(\mathrm{CO}_{2}\right)$ piesaisti, kā arī reizi divos gados jāsagatavo SEG emisiju un $\mathrm{CO}_{2}$ piesaistes prognožu ziņojums un regulāri jāziņo par darbībām, kas veiktas, lai samazinātu SEG emisijas zemes izmantošanas, zemes izmantošanas maiņas un mežsaimniecības sektorā. Precīzas metodes nepieciešamas, lai aprēķinātu $\mathrm{CO}_{2}$ piesaisti kokaugu virszemes un sakṇu biomasā un raksturotu uzkrātā oglekḷa izmaiņas Latvijas mežos. Nozīmīgāko SEG emisiju un $\mathrm{CO}_{2}$ piesaistes avotu uzskaite jāveic ar metodēm, kas raksturo vietējos apstākḷus un ir zinātniski pārbaudītas. Līdzšinējie pētījumi Latvijā par saimnieciski nozīmīgāko koku sugu biomasas un oglekļa apjoma novērtēšanas metodēm veikti fragmentāri, tikai atsevišķu koku sugu un biomasas frakciju līmenī. Starpvalstu klimata pārmaiņu padomes (IPCC) 2006. gada SEG inventarizācijas vadlīniju aprakstîtā biomasas aprēķina metodika piedāvā vidējās blīvuma un biomasas pārrēķina koeficientu vērtības, kuru lietošana Latvijas apstākḷos nav zinātniski pamatota. Pētnieciskais darbs izstrādāts, lai nodrošinātu kokaudžu biomasas un oglekḷa uzkrājuma aprēķinu atbilstību nacionālo ziņojumu sastādīšanas vadlīnijām.

Empīriskais materiāls, Latvijas saimnieciski nozīmīgāko koku sugu virszemes un celma/sakṇu biomasas aprēḳiniem, ievākts 124 meža nogabalos, katrā nozāgéjot trīs dažādu dimensiju paraugkokus. Koku virszemes biomasas vienādojumu izstrādei dati ievākti no 372 kokiem (102 priedēm, 81 eglēm, 105 bērziem un 84 apsēm), bet celma/sakṇu biomasas vienādojumu izstrādei no 141 koka (37 priedēm, 29 eglēm, 42 bērziem un 33 apsēm). Aprēksinot stumbra biomasu, ir nepieciešami precīzi stumbra reducētā blīvuma mērījumi, jo dažādām sugām reducētais blīvums stumbra garenvirzienā un šķērsgriezumā izmainās atšķirīgi. Vidējā stumbra reducētā blīvuma noteikšanai un izmaiņu raksturošanai izmērīti 14366 koksnes un 4652 mizas paraugi.

Pētījumā apstiprinājās, ka priedei, eglei, bērzam un apsei stumbra vidējais mizas blīvums statistiski būtiski $(p<0.001)$ atšķiras no vidējā koksnes blīvuma, tāpēc pētījumā stumbra biomasas aprēķiniem izmantots vidējais svērtais visa stumbra blīvums, kurš aprēķināts visiem paraugkokiem ņemot vērā mizas īpatsvaru stumbrā. Vidējā koksnes blīvuma lietošana stumbra biomasas aprēķinos veido vidēji 1.5-4.5\% kḷūudu, atkarībā no koku sugas. Koka sakṇu, kuru caurmērs pārsniedz $2 \mathrm{~mm}$, biomasas izpēte, tādā apjomā un detalizācijas pakāpē kā mūsu pētījumā, nav veikta nevienā citā pētījumā. Promocijas darba ietvaros izstrādāti jauni Latvijas teritorijai piemēroti stumbra, zaru, kopējās virszemes un celma/sakṇu biomasas aprēķina vienādojumi, kuri lietojami plašā koku dimensiju amplitūdā. Biomasas vienādojumi attiecināmi uz koku sugām kas reprezentē 85.5\% Latvijas kokaudžu krāju. Pētījumā noskaidrots, ka citu Fenoskandijā izstrādāto vienādojumu izmantošana oglekḷa uzkrājumu raksturošanai Latvijas kokaudzēs, veido 4.7-61.7\% kḷūdu atkarībā no koku sugas un virszemes vai celma/sakṇu biomasas frakcijas. SEG inventarizācijas vadlīniju noklusētie mērenās joslas mežu biomasas pārrēķina koeficienti Latvijas kokaudžu oglekļa uzkrājumus palielina par $36.9 \%$, bet boreālo mežu biomasas pārrēķina koeficientu lietošana par 5.2\% samazina oglekḷa uzkrājuma aprēķinus, salīdzinot ar pētījumā izstrādātajiem vienādojumiem. Atbilstoši Latvijas nacionālajā SEG inventarizācijā izmantotajai meža definīcijai, oglekḷa uzkrājums Latvijas kokaudžu biomasā 2016. gadā bija $238.1 \pm 3.5$ milj.t. 


\section{SUMMARY}

Methodology development for forest stand biomass and carbon stock estimates in Latvia. LSFRI "Silava" and Latvia University of Life Sciences and Technologies, 2019. Liepiņš J., supervisors: Dr. silv. Kaspars Liepiņš and Dr. silv. Andis Lazdiņš. The volume of work: 105 pages, 14 charts, 31 figures and 268 references. The doctoral thesis has been elaborated at the Latvian State Forest Research Institute "Silava" and Latvia University of Life Sciences and Technologies, Forest Faculty, Department of forestry from 2014 to 2019.

The significance of the study is determined by the international obligations Latvia has undertaken by ratification of United Nations Framework Convention on Climate Change (UNFCCC), Kyoto Protocol and Paris Agreement. In accordance to UNFCCC requirements, Latvia has to submit a national report on emissions of greenhouse gasses $(\mathrm{GHG})$ and $\mathrm{CO}_{2}$ sequestration annually and every second year - a report on projections of $\mathrm{GHG}$ and $\mathrm{CO}_{2}$ emissions and measures implemented to reduce the GHG emissions in Land Use, Land-Use Change and Forestry (LULUCF) sector. In order to estimate $\mathrm{CO}_{2}$ sequestration in aboveground and belowground woody biomass, accurate methods are required. Accounting of the most significant $\mathrm{GHG}$ emissions and $\mathrm{CO}_{2}$ removals has to be implemented using internationally approved methods that are adapted for local conditions. Previous studies in Latvia on biomass and carbon assessment for economically most important tree species are fragmented and limited to separate biomass fractions and several tree species. Methodology for biomass estimation included in the 2006 Intergovernmental Panel on Climate Change (IPCC) guidelines recommend the use of the default values for wood density, root to shoot ratio and biomass conversion and expansion factors that have not been previously evaluated in Latvian conditions. Our study is aimed to develop the methods for forest biomass and carbon stock assessment that are based on recommendations for national reporting.

The empirical material for study of aboveground and belowground tree biomass is collected in 124 forest stands. Three sample trees per stand have been harvested - 372 trees in total for aboveground biomass studies (102 Scots pines, 81 Norway spruces, 105 birches (Betula sp.) and 84 European aspen), while 141 stumps and roots are lifted for belowground biomass studies (37 Scots pines, 29 Norway spruces, 42 birches (Betula spp.) and 33 European aspens). 14366 stem wood and 4652 stem bark samples have been analysed to study the variation of within-the-stem basic density and to calculate the mean density of the stems.

Our study approved that the basic density of stem bark significantly $(p<0.001)$ differs from stem wood density. Because of this in order to estimate biomass we used average weighted basic density values for whole stem (wood and bark). The use of mean stem wood density values instead of whole stem density values leads to biased estimation of stem biomass (1.5-4.5\% error depending on tree species). Examination of small root (diameter over $2 \mathrm{~mm}$ ) biomass performed in our study to such an extent has not been done before. Within our study new equations for estimation of stem, branch, total aboveground and belowground biomass were developed for application in Latvian conditions for a wide range of tree dimensions. The tree species included in the study for elaboration of biomass equations represent $85.5 \%$ of forest growing stock in our country. We found that the use of biomass equations applied for biomass estimation in Fennoscandia in our conditions are creating an 4.7-61.7\% error depending on tree species and biomass component. Application of default values of biomass expansion factors and root to shoot ratios for temperate and boreal forests defined in IPCC guidelines creates an overestimation of $36.9 \%$ and an underestimation of $5.2 \%$, respectively in comparison to methodology elaborated and recommended in our study. In accordance to the forest definition used in national IPCC reports, the total carbon stock in Latvia in year 2016 was $238.1 \pm 3.5$ million tonnes. 


\section{SATURS}

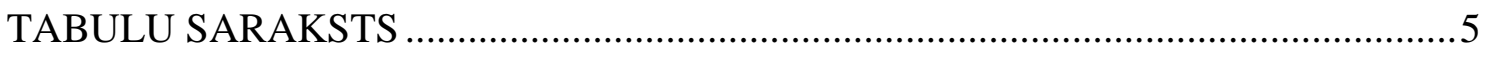

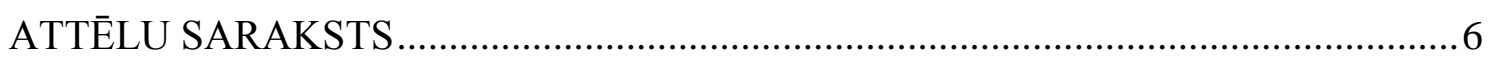

PUBLIKĀCIJAS PAR PROMOCIJAS DARBA TĒMU …...................................... 7

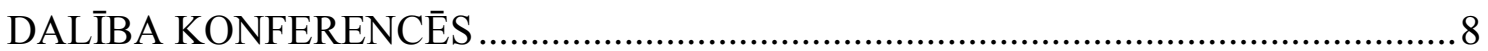

PROMOCIJAS DARBĀ LIETOTIE SAĪSINĀJUMI .............................................

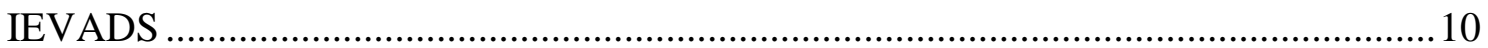

1. OGLEKL_A PIESAISTES UN KOKAUDŽU BIOMASAS

NOTEIKŠANAS PROBLEMĀTIKAS ANALİZE ............................................... 13

1.1. Oglekḷa globālās aprites dinamika un piesaiste............................................ 13

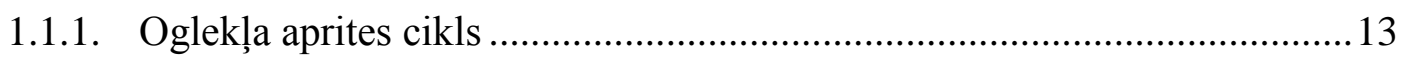

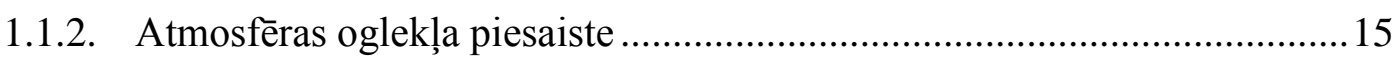

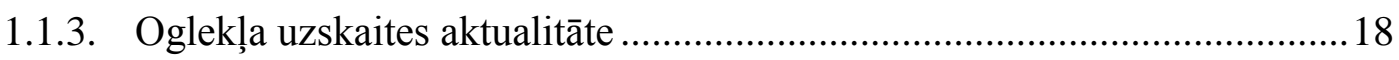

1.2. Kokaudžu biomasas novērtēšanas metodes ................................................2 21

1.2.1. Virszemes biomasas novēertēšana .........................................................2 21

1.2.2. Sakņu un celma biomasas novērtēšana..................................................23

1.2.3. Alometrisko sakarību izmantošanas iespējas ...........................................22

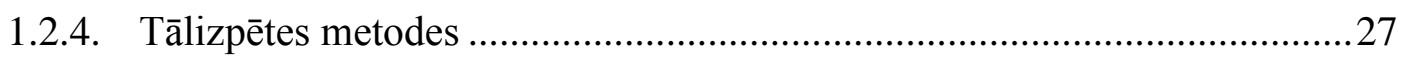

1.3. Reducētā blīvuma nozīme biomasas un oglekḷa uzkrājumu novērtēšanā.......29

1.4. Oglekḷa novērtēšanas metožu salīizinājums Eiropas mežos..........................32

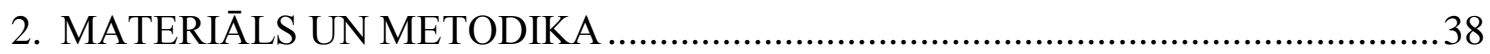

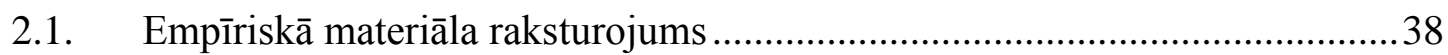

2.2. Koku virszemes biomasas empīiriskā materiāla ievākšana un apstrāde..........40

2.3. Koku celma/sakṇu biomasas empīriskā materiāla ievākšana un apstrāde......43

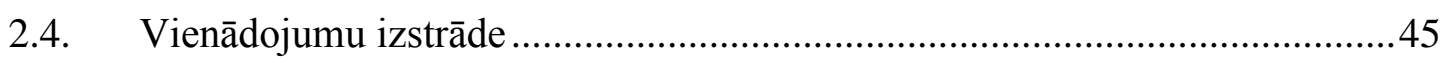

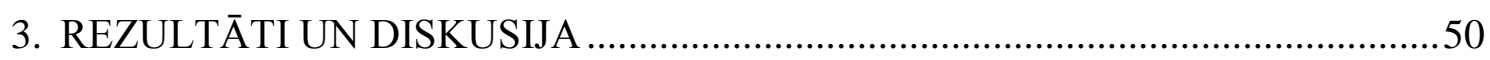

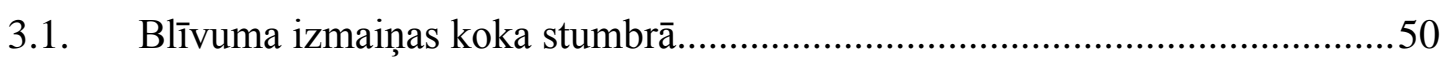

3.2. Koku biomasas aprēḳini un vienādojumu izstrāde .....................................59

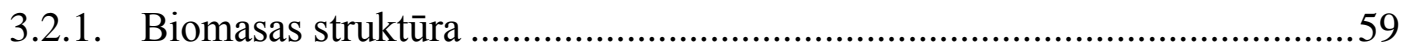

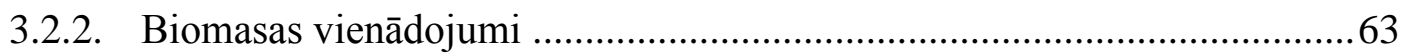

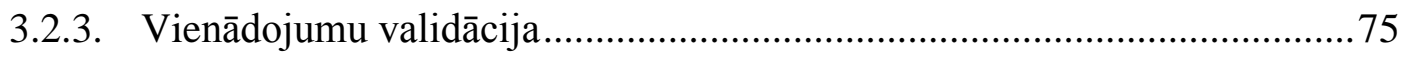

3.3. Latvijas kokaudzēs uzkrātais ogleklis atbilstoši Latvijas

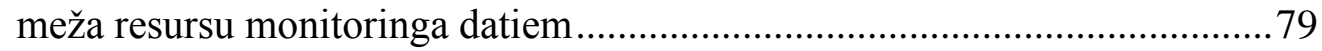

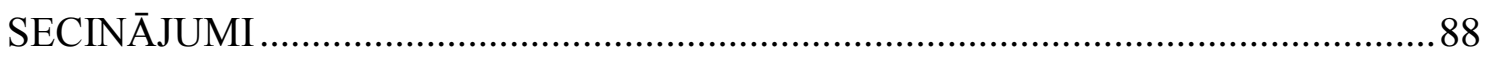

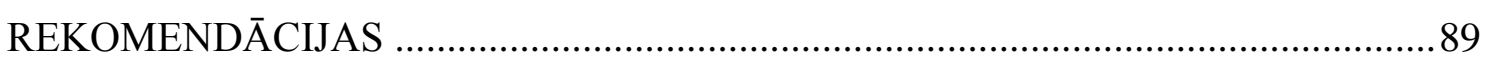

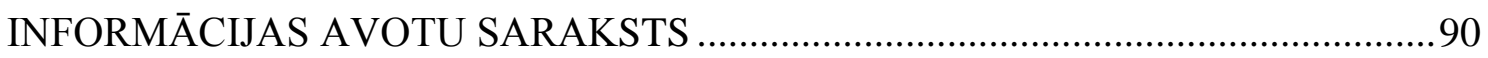




\section{TABULU SARAKSTS}

1.1. tabula. Celma/sakṇu biomasas novērtēšanas metodes (Addo-Danso et al., 2016) 23

1.2. tabula. Reducētā blīvuma vērtības Latvijai raksturīgām koku sugām (Eggleston et al., 2006)

1.3. tabula. Kokaudžu biomasas aprēķina metožu salīdzinājums dažādās Eiropas valstīs

1.4. tabula. Dažādās Eiropas valstīs lietotais oglekḷa saturs biomasā

2.1. tabula. Atlasīto meža nogabalu vidējo rādītāju raksturojums atkarībā no valdošās koku sugas..... 38

2.2. tabula. Paraugkoku raksturojums virszemes biomasas aprēkiniem....................................39

2.3. tabula. Paraugkoku raksturojums celma/sakṇu biomasas aprēķiniem............................. 43

3.1. tabula. Vidējās mizas īpatsvara vērtības no kopējā stumbra tilpuma \pm standartkḷūda atkarībā no koka krūšaugstuma caurmēra. 49

3.2. tabula. Koku sugu svērtās vidējās reducētā blīvuma vērtības \pm standartnovirze ...............51

3.3. tabula. Paraugkoku biomasas frakciju raksturojums, $\mathrm{kg}$............................................58

3.4. tabula. Regresijas vienādojumu koeficientu vērtības un to statistiskie rādītāji .................64

3.5. tabula. Promocijas darbā un citos pētījumos izstrādāto vienādojumu biomasas aprēķinu relatīvā starpība atkarībā no vidējā krūšaugstuma caurmēra ..................75

3.6. tabula. Sauso zaru īpatsvara kopējā zaru biomasā (BB) korelācija ar koku krūšaugstuma diametru (D) un augstumu $(\mathrm{H})$.................................................... 78

3.7. tabula. Mežu resursu monitoringa (MRM) datubāzē koku sugām piemērotie biomasas vienādojumi Latvijas kokaudžu oglekḷa aprēķiniem 


\section{ATTĒLU SARAKSTS}

1.1. att. Oglekḷa plūsma starp galvenajām oglekḷa krātuvēm (Lal, 2008) ................................13

1.2. att. Potenciālās oglekḷa piesaistes iespējas, balstoties uz literatūrā pieejamo informāciju.

1.3. att. Latvijas atrašanās vieta hemiboreālo mežu joslā pēc

Ahti, Hämet-Ahti, \& Jalas, (1968) un EEA (2007)

1.4. att. Veicamās darbības novērtējot kokaugu virszemes biomasu pēc

Breu, Guggenbichler, \& Wollmann (2012)

1.5. att. GlobAllomeTree datubāzē ievietotie biomasas alometriskie vienādojumi

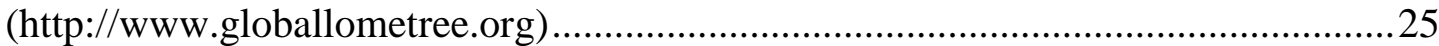

1.6. att. Koksnes blīvums atkarībā no koksnes mitruma (Kops, 1997) ...................................29

2.1. att. Pētìjumu objektu izvietojums Latvijas teritorijā. ..................................................... 37

2.2. att. Koku klasifikācija pēc ārējā izskata un vainaga īpašīiām (FAO, 2014).....................38

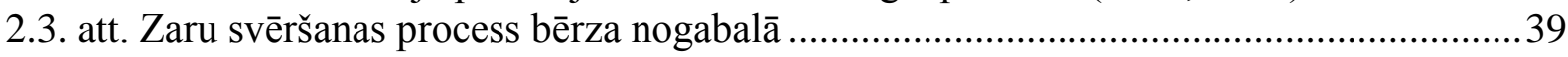

2.4. att. Blīvuma paraugu novietojums stumbra šķērsgriezuma ripās ..................................... 40

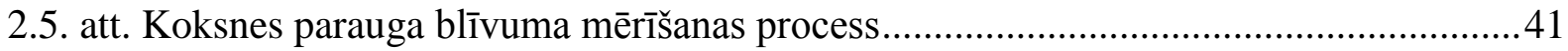

2.6. att. Atrakta un nomazgāta parastās priedes sakṇu sistēma ...............................................44

3.1. att. Mizas īpatsvars stumbra šķērsgriezumā atkarībā no relatīvā augstuma ....................50

3.2. att. Vidējā stumbra koksnes (punktētā līnija) un stumbra mizas (nepārtrauktā līnija) reducētā blīvuma izmaiņas stumbra garenvirzienā ................................................52

3.3. att. Stumbra koksnes reducētā blīivuma izmainas atkarīibā no koka krūšaugstuma caurmēra.

3.4. att. Koksnes reducētais blīvums (a) priedes, (b) egles un (c) bērza stumbru garenvirzienā pēc Repola (2006) vienādojumiem (pelēkā līnija)

un mūsu mērījumiem (melnā, pārtrauktā līnija) ......................................................55

3.5. att. Koksnes reducētā blīvuma izmaiņas priedes un bērza stumbros................................56

3.6. att. Koksnes reducētā blīvuma izmaiņas egles un apses stumbros ...................................57

3.7. att. Kopējās biomasas sadalījums sauso zaru, dzīvo zaru, stumbra mizas, stumbra koksnes, celma, balstsakṇu $(>2 \mathrm{~cm})$, un sīko sakṇu $(<2 \mathrm{~cm})$ frakcijās .....................6 60

3.8. att. Virszemes uz sakņu biomasas pārrēķina attiecības izmaiņas atkarībā no koku krūšaugstuma caurmēra

3.9. att. Vienādojumu ticamības novērtējums pēc divu AICc vērtību starpības .....................66

3.10. att. Aprēķināto un prognozēto biomasas vērtību izkliedes diagramma

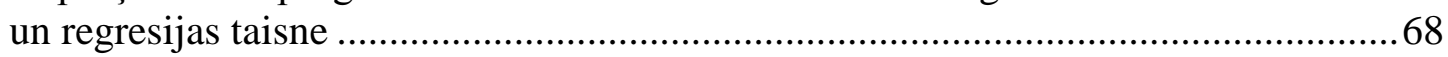

3.11. att. Vienādojuma 2.7 atlikumu sadalījuma struktūra. Pārtrauktā līnija

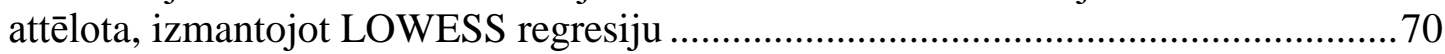

3.12. att. Vienādojuma 2.6 atlikumu sadalījuma struktūra. Pārtrauktā līnija attēlota, izmantojot LOWESS regresiju

3.13. att. Vienādojuma 2.5 atlikumu sadalījuma struktūra. Pārtrauktā līnija attēlota, izmantojot LOWESS regresiju

3.14. att. Sagaidāmā virszemes (AGB) un celma/sakṇu (BGB) biomasa atkarībā no pielietotā vienādojuma.

3.15. att. Uzkrātais ogleklis kokaudžu virszemes biomasā (AGB) un celma/sakņu biomasā (BGB) pielietojot dažādas aprēķinu metodes...

3.16. att. Uzkrātais ogleklis pēc valdošās koku sugas aizṇemtās platības pielietojot dažādas aprēķinu metodes.

3.17. att. Koku stumbrā, zaros un celmos/saknēs uzkrātais ogleklis atkarībā no sugas ...........83

3.18. att. Dažāda vecuma audzēs uzkrātais ogleklis pēc valdošās koku sugas.........................84

3.19. att. Oglekḷa uzkrājuma vidējo slīdošo vērtību dinamika Latvijā atkarībā no aprēķinu perioda. 


\section{PUBLIKĀCIJAS PAR PROMOCIJAS DARBA TĒMU}

1. Liepiņš, J., Lazdiņš, A., Liepiņš, K. (2018). Equations for estimating above- and belowground biomass of Norway spruce, Scots pine, birch spp. and European aspen in Latvia. Scandinavian Journal of Forest Research. 33(1), 58-70. DOI: 10.1080/02827581.2017.1337923 (IF $2017=1.600$ )

2. Liepiņš, J., Ivanovs, J., Lazdiņš, A., Jansons, J., Liepiņš, K. (2017). Mapping of basic density within European aspen stems in Latvia. Silva Fennica. 51(5), 9p DOI: $10.14214 /$ sf. 7798 (IF $2017=1.683$ )

3. Liepiņš, J., Liepiņš, K. (2017). Mean basic density and its axial variation in Scots pine, Norway spruce and birch stems. In Research for Rural Development 23rd Annual International Scientific Conference Proceedings. (Vol. 1, pp. 21-27). DOI: 10.22616/rrd.23.2017.003

4. Liepiṇš, J., Liepiņš, K. (2015). Evaluation of bark volume of four tree species in Latvia. In Research for Rural Development. 21rd Annual International Scientific Conference Proceedings. (Vol. 2, pp. 22-28). ISSN: 16914031 


\section{DALĪBA KONFERENCĒS}

1. The Annual 24rd International Scientific Conference "Research for Rural Development 2018", 16.05. - 18.05.2018. Jelgava, Latvia. Prezentācija - Liepiṇš, J., Ivanovs, J., Lazdinšs, A., Jansons, J., Liepinšs, K. Variation of basic density in stems of European aspen wood and bark.

2. Linking belowground biodiversity and ecosystem function in European forests (BioLink) during yr. 2015 - 2018, 14.05. - 16.05.2018. Granada, Spain. Stenda referāts Daugaviete, M., Lazdiña, D., Celma, S., Bārdule, A., Bārdulis, A., Liepin̦š, J., Liepiņšs, K., Lazdinšs, A., Jansons, Ā., Ķēniņa, L., Zeps, M. Realized and ongoing research projects in frame of COST Action FP 1305 in Latvian Forest Research Institute Silava.

3. Starptautiski zinātniski praktiskā konference "Zinātne un prakse nozares attīstībai", 15.03 - 17.03.2017. Jelgava, Latvija. Prezentācija - Liepiņš, J., Liepiņš, K. Koksnes blīvuma izmaiņas priedes, egles un bērzu stumbru garenvirzienā.

4. 11th International Scientific Conference „Students on their way to science”, 22.04.2016. Jelgava, Latvia. Prezentācija - Liepiņš̌, J., Liepiņš, K. Estimation of the biomass stock from growing stock volume.

5. International Scientific Conference of the forest sector „Knowledge based forest sector”, 4.11 - 6.11. 2015. Rīga, Latvija. Prezentācija - Liepiņš, J., Lazdiņš, A., Liepiņš, K. Above - and belowground biomass functions for four most common tree species in Latvia.

6. International Scientific Conference of the forest sector „Knowledge based forest sector”, 4.11 - 6.11. 2015. Rīga, Latvija. Prezentācija - Lazdiṇš, A., Liepiṇš, J., Liepiņš, K., Bārdule, A., Butlers, A. Results of research program on evaluation of impact of forest management measures on greenhouse gas emissions and $\mathrm{CO}_{2}$ removals.

7. 10th International Scientific Conference „Students on their way to science”, 24.04.2015, Jelgava, Latvia. Prezentācija - Muižnieks, E., Liepiņš, J., Lazdiņš, A. Carbon content in biomass of the most common tree species in Latvia.

8. The Annual 21st International Scientific Conference „Research for Rural Development 2015”, 13.05 - 15.05.2015. Jelgava, Latvia. Prezentācija - Liepin̄š, J., Liepiņš, K. Evaluation of bark volume of four tree species in Latvia.

9. Conference „Adaptation and mitigation: strategies for management of forest ecosystems”, 23.04 - 24.04.2015. Riga, Latvia. Prezentācija - Liepiṇš, J., Liepiņš, K., Lazdiṇš, A. Biomass equations for the most common tree species in Latvia.

10. Zinātniski praktiskā konference ,Zinātne un prakse nozares attīstībai”, 16.04 19.04.2015. Jelgava, Latvija. Prezentācija - Liepiņš̌, J. Mizas apjoma modelēšana Latvijas saimnieciski nozīmīgajām koku sugām.

11. 9th Baltic Theriological Conference „Forest ecosystem and its management: towards understanding the complexity", 15.10.2014. Daugavpils, Latvia. Prezentācija Liepiņšs, J., Liepiņš, K., Lazdiņš, A. Biomass studies for most common tree species in Latvia.

12. 9th Baltic Theriological Conference „Forest ecosystem and its management: towards understanding the complexity”, 15.10.2014. Daugavpils, Latvia. Prezentācija - Mūrniece, S., Lazdiņš, A., Liepiņš, J. Decomposition of below-ground biomass in coniferous forest stands in Latvia. 


\section{PROMOCIJAS DARBĀ LIETOTIE SAĪSINĀJUMI}

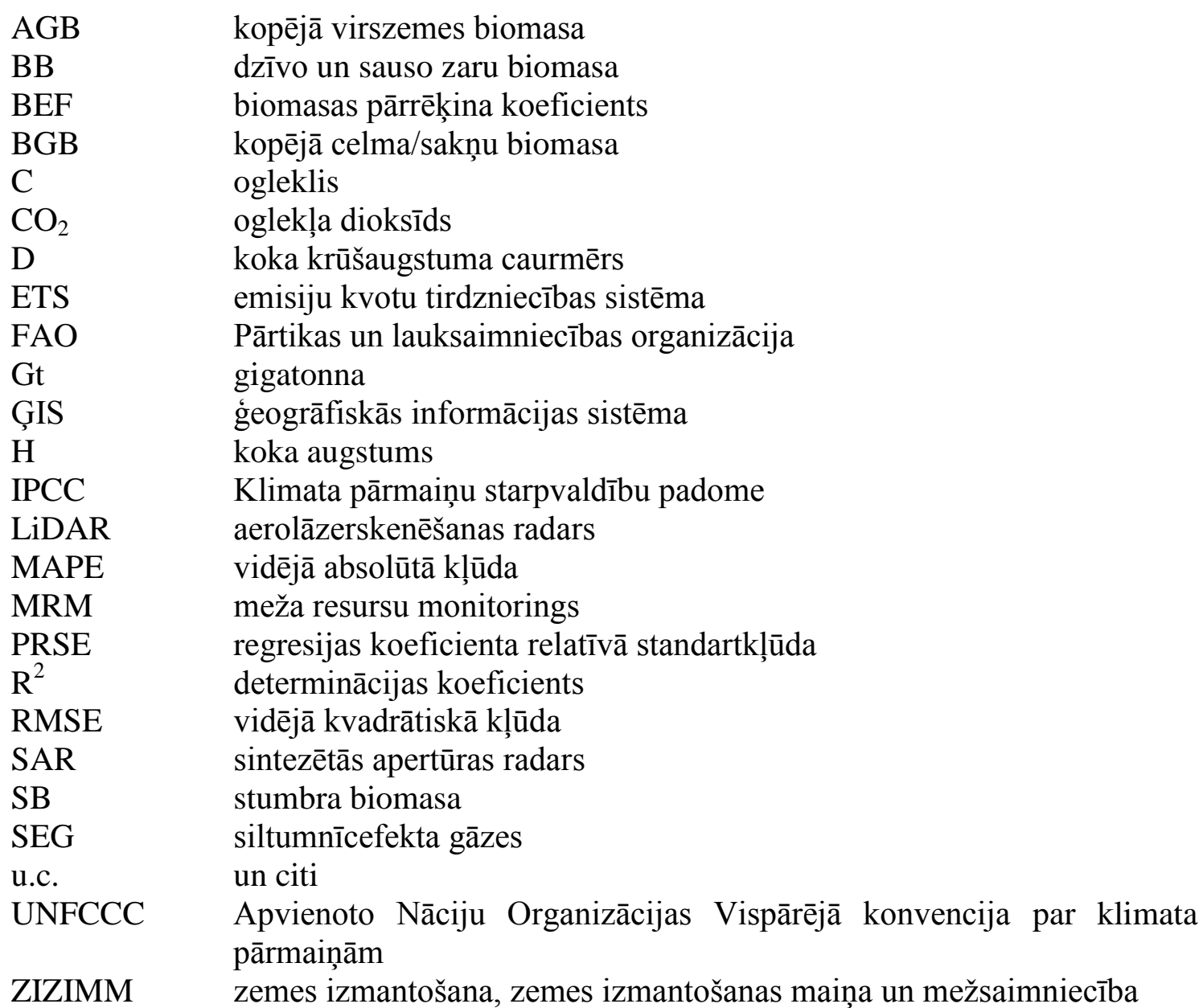




\section{IEVADS}

Nepieciešamība stabilizēt oglekḷa dioksīda $\left(\mathrm{CO}_{2}\right)$ un citu siltumnīcefekta gāzu (SEG) koncentrāciju atmosfērā, lai mazinātu antropogēno ietekmi uz klimata izmaiņām, ir aktualizēta vairākos starptautiskos nolīgumos, tajā skaitā Kioto protokolā un Parīzes nolīgumā, kuri realizēti Eiropas Savienības klimata politikā. Oglekḷa daudzumu atmosfērā iespējams normalizēt, ne tikai samazinot $\mathrm{CO}_{2}$ emisijas un sekmējot fosilā kurināmā aizstāšanu ar biomasu, bet arī veicinot atmosfērā esošā $\mathrm{CO}_{2}$ piesaisti un saistīto oglekli uzglabājot dažādās krātuvēs. Liela $\mathrm{CO}_{2}$ noplūžu riska un augsto uzglabāšanas izmaksu dēl abiotiskās oglekḷa piesaistes tehnoloǵijas varētu būt plašāk izmantojamas pēc 2025. gada (Lal, 2008), tāpēc šobrīd pasaule lielāks uzsvars tiek likts tieši uz dabiskām $\mathrm{CO}_{2}$ piesaistes metodēm okeānos un sauszemes ekosistēmās. N̦emot vērā pašreizējo zināšanu līmeni, joprojām nav skaidrs, kā papildus oglekḷa uzglabāšana okeānos var mainīt to ekologiju ilgtermiņā (Chisholm, 2001; Williamson et al., 2012), kamēr atmosfērā esošā $\mathrm{CO}_{2}$ piesaiste ar fotosintēzi jau no klimata pārmaiņu problēmas pirmsākumiem ir atzīta par piemērotu metodi gāzes samazināšanai atmosfērā , kas nerada negatīvu ietekmi uz vidi (Lal, 2008).

Meža ekosistēmā $\mathrm{CO}_{2}$ piesaiste notiek pamatā kokaugu virszemes un sakṇu biomasā un tad humifikācijas procesā dạ̧a no oglekḷa tiek uzkrāts augsnē (Gren \& Zeleke, 2016). Kokaugi un lakstaugi fotosintēzes procesā izmanto saules gaismu, lai $\mathrm{CO}_{2}$, ūdeni un barības vielas sintezētu par cukuriem un og̣̣hidrātiem, kas uzkrājas koka frakcijās, piemēram, lapās, zaros, stumbrā, saknēs (Gorte, 2009). Beidzoties dzīves ciklam, lielākā daḷa no augos uzkrātā oglekḷa sadalīšanās procesā nonāk atpakal atmosfērā, bet atlikušais papildina augsnes oglekḷa krājumus. Visas koku dạ̧as satur oglekli, bet tā saturs dažādu koku sugu frakcijās (zari, stumbrs, saknes) nedaudz atšķiras. Koku biomasā uzkrātā oglekḷa daudzumu aprēķina, reizinot dažādu koka frakciju biomasu ar oglekl̦a saturu un summējot iegūtos rezultātus.

Lai gan SEG koncentrācijas pieaugums atmosfērā galvenokārt ir antropogēnu darbību rezultātā, galvenais uzsvars oglekļa bilances uzlabošanā pasaulē, paralēli fosilo resursu izmantošanas ierobežošanai, kas ir arī lielākais antropogēno emisiju avots, tiek likts uz $\mathrm{CO}_{2}$ biologiiskās piesaistes veicināšanu. Zemes izmantošanas, zemes izmantošanas maiņas un mežsaimniecības (ZIZIMM) sektors rada vislielāko ietekmi uz SEG emisijām un $\mathrm{CO}_{2}$ piesaisti Latvijā. Mūsu valsts $\mathrm{CO}_{2}$ piesaiste augošu koku biomasā būtiski pārsniedz visu pārējo tautsaimniecības sektoru kopējās SEG emisijas. Par cik Latvija ir Eiropas Savienības un starptautisko nolīgumu dalībvalsts, ir svarīgi, lai mēs prastu ar maksimālu precizitāti novērtēt mežaudžu $\mathrm{CO}_{2}$ piesaisti, tādējādi mazinot saistību pārvērtēšanas riskus. Neskatoties uz ZIZIMM sektora nozīmīgumu, metodiskā bāze $\mathrm{CO}_{2}$ piesaistes analīzei šajā sektorā ir nepilnīga. Viens no lielākajiem trūkumiem ir nepilnīgas zināšanas par Latvijas mežaudzēs uzkrāto oglekḷa apjomu un metodiski korektu biomasas aprēķina vienādojumu neesamība tā aprēķināšanai. Dažādu koku sugu biomasas frakcionālais sadalījums būtiski atšķ̌iras, tāpēc atsevišķi biomasas vienādojumi nepieciešami visām izplatītākajām koku sugām.

Precīzas metodes nepieciešamas ne tikai, lai aprēķinātu $\mathrm{CO}_{2}$ piesaisti augošu kokaugu biomasā, bet arī, lai raksturotu koksnes produktos, biokurināmajā, nobirās nedzīvajā koksnē un augsnē saistītā oglekḷa daudzumu. Pētîjuma aktualitāti nosaka starptautiskās saistības, ko Latvija apņēmusies pildīt, ratificējot Apvienoto Nāciju Organizācijas Vispārējo konvencija par klimata pārmaiņām (UNFCCC) 1995. gadā, tās Kioto protokolu 2002. gadā un Parīzes vienošanos 2016. gadā. Saskaņā ar Kioto protokolu, Latvijai SEG emisijas laika posmā no 2008.-2012. gadam bija jāsamazina par 8\%, salīdzinot ar 1990. gadu. Tomēr, atbilstoši Kankunas konferencei, kura notika Meksikā 2010. gadā, līdz 2020. gadam SEG emisijas plānots samazināt vēl par 20-30\%. $\mathrm{CO}_{2}$ piesaiste kokaugu biomasā iekḷauta Kioto protokolā kā viens no mehānismiem SEG emisiju radīto klimata izmaiņu mazināšanai globālā mērogā.

Zinātniskajā literatūrā ir plaši diskutēts par koku virszemes un celma/sakṇu biomasas mainību pat vienas sugas ietvaros, secinot, ka sagaidāmo biomasu ietekmē, piemēram, veǵetācijas zonas, platuma grādi, ūdens deficîts, gada vidējā temperatūra un citi faktori 
(Berninger et al., 1995; Stegen et al., 2011; Wirth, Schumacher, \& Schulze, 2004 u.c.). Visa Latvijas teritorija atrodas Eiropas hemiboreālajā mežu joslā (Ahti, Hämet-Ahti, \& Jalas, 1968; EEA, 2007) kura izvietota starp mēreno un boreālo mežu joslu. Šì pārejas zona kartēs ir attēlota kā šaura josla, pēc augšanas apstākļiem līdzīgāka boreālajiem mežiem, tomēr ar lielāku koku sugu daudzveidību, kā arī mitru un mēreni vēsu klimatu. Hemiboreālais reǵions ir salīdzinoši neliels un tajā līdz šim nav veikti plašāki pētîjumi par oglekḷa piesaisti izplatītāko koku sugu mežaudzēs.

Ziemel̦eiropā (Fenoskandija un Baltijas valstis) priedei, eglei un bērzam biomasas vienādojumi, kas balstīti uz plašu un reprezentatīvu empīrisko materiālu, ir izstrādāti Zviedrijā (Marklund, 1987, 1988; Petersson \& Stahl, 2006) un Somijā (Repola, 2008, 2009). Piemēram, Norvēgijas kokaudžu oglekḷa uzkrājuma aprēķinu metodika izmanto Zviedrijā izstrādātus biomasas vienādojumus (Neumann et al., 2016). Tomēr apstiprinājies, ka bērza biomasas vienādojumu ǵeogrāfiska ekstrapolācija pat vienas veǵetācijas zonas ietvaros būtiski palielina kḷūdu biomasas, līdz ar to oglekl̦a uzkrājuma aprēķinos Norvēgéijas apstākḷlos, pamatojot nepieciešamību pēc vietējiem biomasas vienādojumiem (Smith et al., 2014; Smith, Granhus, \& Astrup, 2016). Arī Somijā oglekḷa apjoma aprēķina metodika rekomendē lietot lokāli izstrādātos vienādojumus, pamatojoties uz atšksirīgajiem rezultātiem, kuri iegūti, Somijas apstākl̦os lietojot Zviedrijā izstrādātos biomasas vienādojumus (Repola, 2008, 2009).

Latvijā līdzšinējie pētījumi par koku biomasas un oglekḷa satura novērtēšanas metodēm saimnieciski nozīmīgākajām koku sugām veikti fragmentāri - atsevišķu koku sugu un biomasas frakciju līmenī. Liepa un Blija (2008) ir aprakstījuši Latvijas egl̦u mežu koku biomasas struktūru balstoties uz 21 paraugkoku datiem no Zemgales. Ar dažādām vienādojumu izteiksmēm ir mēgeināts aprakstìt 40-gadīgu egl̦u virszemes biomasu (Lībiete et al., 2017) un secināts, ka lokāli izstrādātie vienādojumi demonstrēja ievērojami augstāku precizitāti nekā Somijā izstrādātie. Promocijas darbā Bārdulis (2013) ir raksturojis priežu jaunaudžu sakṇu biomasas izmaiņas sausieņu meža tipos. Ir veikti daži pētījumi par oglekḷa akumulāciju virszemes un sakņu biomasā priedes, egles un bērza stādījumos lauksaimniecības zemēs (Andis Bārdulis et al., 2017; Daugaviete et al., 2008). Ir pieejamas dažādu autoru (Bārdulis et al., 2015; Daugaviete, 2010; Miezīte, Liepa, \& Lazdiņ̌̌, 2011) publikācijas par baltalkšņu audžu virszemes un sakņu biomasas aprēķiniem un noteikšanas metodēm. Iepriekš veikto pētījumu metodikas ne vienmēr ir saskaņotas, tāpēc oglekḷa satura, kā arī koku biomasas dati nav salīdzināmi un nav izmantojami Latvijas SEG inventarizācijas ziņojumiem.

SEG aprēķina vadlīnijās rekomendētie noklusējuma koeficienti biomasas noteikšanai Latvijas mežaudzēs nav zinātniski pamatoti un tāpēc to izmantošana nebūtu pieļaujama atbilstoši vadlīnijās ietvertajiem nosacījumiem par zinātniski verificētu metožu pielietošanu nozīmīgu $\mathrm{CO}_{2}$ piesaistes avotu aprēķiniem. Turpretī, nekorektu un nepārbaudītu citu valstu vienādojumu izmantošana SEG emisiju un $\mathrm{CO}_{2}$ piesaistes aprēķinos var būtiski ietekmēt aprēķinu rezultātus gan oglekḷa uzkrājumu palielinājuma, gan samazinājuma virzienā, kā arī radīt nepareizu priekšstatu par klimata izmaiņu mazināšanas darbību ietekmes kvantitatīvajiem rādītājiem. Tāpēc, lai nodrošinātu biomasas aprēķinu atbilstību nacionālo ziņojumu sagatavošanas vadlīnijām, tiek izstrādāts pētnieciskais darbs, kura mērķis ir izveidot alometriskos vienādojumus saimnieciski nozīmīgāko koku sugu biomasas raksturošanai un noteikt Latvijas kokaudzēs uzkrāto oglekli.

Pētîjumā izvirzītas šādas tēzes.

1. Koksnes vidējo blīvuma vērtību izmantošana visa koka stumbra biomasas aprēķināšanai veido sistemātisku kḷūdu, kuras lielums ir atšķirīgs dažādām koku sugām.

2. Starpvalstu klimata pārmainu padomes 2006. gada SEG inventarizācijas vadlīniju piedāvāto biomasas pārrēķina koeficientu un Fenoskandijā izstrādāto biomasas vienādojumu izmantošana rada kḷūdu novērtējot Latvijas kokaudzēs uzkrāto oglekli.

Lai sasniegtu pētnieciskā darba mērķi, izvirzīti sekojoši pētnieciskie uzdevumi.

1. Raksturot vidējo stumbra reducēto blīvumu, tā telpiskās izmaiņas stumbra garenvirzienā un šksērsgriezumā. 
2. Izstrādāt parastās priedes (Pinus sylvestris L.), parastās egles (Picea abies (L.) H. Karst.), bērzu (Betula sp.) un parastās apses (Populus tremula L.) atsevišķu koku virszemes, celma/sakṇu, stumbra un zaru biomasas vienādojumus.

3. Novērtēt kokaudžu biomasā uzkrātā oglekḷa daudzumu, izmantojot Latvijas meža resursu monitoringa datus.

Promocijas darbs izstrādāts analizējot Meža nozares kompetences centra (MNKC) pētījumu programmas "Metodes un tehnoloǵijas meža kapitālvērtības palielināšanai" ietvaros pētniecības projektā "Siltumnīcefekta gāzu emisiju un $\mathrm{CO}_{2}$ piesaistes pêtījumu programma" ietvaros iegūtos datus. Pētījuma īstenošanas termiņš 2011.-2015.gads. 


\section{OGLEKL̦A PIESAISTES UN KOKAUDŽU BIOMASAS NOTEIKŠANAS PROBLEMĀTIKAS ANALİZE}

\subsection{Oglekḷa globālās aprites dinamika un piesaiste}

\subsubsection{Oglekḷa aprites cikls}

Par klimata pārmaiņām pēdējā laikā tiek diskutēts aizvien vairāk - par tām runā gan zinātnieki, gan politiķi. Klimata pārmaiņas var rasties dabiskā ceḷā un tās izraisa, piemēram, zemes plātņu tektonika, vulkāniskā aktivitāte, saules, zemes, okeānu un atmosfēras savstarpēja mijiedarbība, arī saules aktivitātes maiņa, tomēr parasti šādas klimata pārmaiņas notiek ļoti lēni - vairāku tūkstošu gadu laikā. Patlaban klimats mainās l̦oti strauji. Zemeslodes virsmas vidējā temperatūra kopš industriālā perioda sākuma ir palielinājusies par $0.55-0.8^{\circ} \mathrm{C}$, salīdzinot ar 1986.-2005. gadu, bet 2015. gadā vidējā temperatūra pirmo reizi paaugstinājās vairāk nekā par $1{ }^{\circ} \mathrm{C}$ (Hawkins et al., 2017). Strauji paaugstinoties zemeslodes virsmas temperatūrai, notiek ievērojamas pārmaiņas ekosistēmās (Greene \& Pershing, 2007), paaugstinās ūdens līmenis okeānos, palielinās savvaļas ugunsgrēku biežums un intensitāte (Westerling, 2006). Minēto un arī citu klimata pārmaiṇu cēlonis pēc daudzu zinātnieku domām ir antropogēnās darbības (zemes lietojuma maiņa, atmežošana, biomasas dedzināšana, mitrāju nosusināšana, augsnes apstrāde, fosilo resursu lietošana u.c) kuru rezultātā atmosfērā palielinās SEG emisijas. Līdz ar to, palielinoties cilvēku populācijai, pakāpeniski palielinājusies arī SEG koncentrācija atmosfērā, jo īpaši tā palielinājusies kopš industriālā perioda sākuma, kas tiek datēts ap 1780.-1800. gadu (Hawkins et al., 2017).

Galvenā cilvēku sabiedrības radītā SEG ir $\mathrm{CO}_{2}$. Minētā gāze veido apmēram 74\% no visām cilvēka radītajām SEG un tā galvenokārt izdalās, sadegot fosilajiem kurināmajiem kā akmeņoglēm, naftai un dabasgāzei (WRI, 2012). Oglekḷa daudzumu un tā plūsmu var izteikt oglekḷa vienībās vai arī $\mathrm{CO}_{2}$ vienībās (1 kg oglekḷa ir ekvivalents ar $3.67 \mathrm{~kg} \mathrm{CO}$ ) (IPCC, 2003). Pasaules sabiedrība ir izpratusi nepieciešamību stabilizēt $\mathrm{CO}_{2}$ un citu SEG koncentrāciju atmosfērā, lai mazinātu globālās sasilšanas procesu. Pamatā ir izdalītas trīs stratēgijas $\mathrm{CO}_{2}$ koncentrācijas atmosfērā samazināšanai (Schrag, 2007): samazināt globālo enerǵijas patērinu, attīstīt enerǵijas veidus ar zemām $\mathrm{CO}_{2}$ emisijām un piesaistīt $\mathrm{CO}_{2}$ no atmosfēras ar dabiskiem un inženiertehniskiem paṇēmieniem.

Oglekḷa apmaiņa starp dažādiem tā avotiem un piesaistītājiem notiek nepārtraukti un šo procesu sauc par oglekḷa aprites ciklu. Aprites cikls aptver vairākas oglekḷa krātuves, starp kurām notiek dinamiskas oglekḷa plūsmas vienā vai dažādos virzienos. Tā kā lielākā daļa no oglekḷa apmaiņas reakcijām attiecas uz $\mathrm{CO}_{2}$, tad cikla elementi, ko mēs pazīstam kā oglekḷa piesaistītājus, patiesībā ir $\mathrm{CO}_{2}$ piesaistītāji (Beijere et al., 2006).

Globālā oglekḷa aprites cikla izpratne ir svarīga, izstrādājot potenciālās stratēgijas klimata pārmaiṇu mazināšanā. Uz zemeslodes ir piecas galvenās oglekḷa krātuves (1.1. attēls) - fosilie resursi, atmosfēra, okeāns, biotiskā vide (dzīvie organismi) un pedosfēra, jeb augsne virs pamatieža (Lal, 2008). No minētajām oglekḷla krātuvēm lielākā ir okeāns, tajā akumulēts apmēram $38400 \mathrm{Gt}$ oglekḷa un tā apjomi krātuvē palielinās vidēji ar ātrumu $2.3 \mathrm{Gt}$ oglekḷa gadā. Ģeologiiskā oglekḷa krātuve, ietverot visus fosilos resursus, ir otra lielākā. Fosilo resursu oglekḷa krājumi tiek lēsti apmēram $4130 \mathrm{Gt}$, no tiem lielākais oglekḷa apjoms akumulēts akmeņoglēs $(85 \%)$, naftā $(5.5 \%)$ un dabasgāzē (3.3\%). Akmeņogles un nafta veido apmēram $40 \%$ no pasaules $\mathrm{CO}_{2}$ emisijām (Schrag, 2007), bet nākotnē akmeņogḷu patēriņš varētu arī pieaugt. Sadedzinot fosilos resursus, oglekḷa apjomi krātuvē samazinās vidēji par 7 Gt gadā tam nonākot atmosfērā, bet, pieaugot akmeņoģ̣u patēriņam $\mathrm{CO}_{2}$ plūsma uz atmosfēru turpinās palielināties. Trešā lielākā oglekḷa krātuve ir augsne līdz $1 \mathrm{~m}$ dziḷumam jeb pedosfēra. Pedosfēra ietver augsnes organisko oglekli apmēram 1462-1548 Gt un augsnes neorganisko oglekli 695-748 Gt (Batjes, 2014). Ceturtā lielākā oglekḷa krātuve ir atmosfēra $760 \mathrm{Gt}$ kurā tas sastopams $\mathrm{CO}_{2}$ veidā, savukārt vismazākā ir biotiskā vide - 560 Gt. 


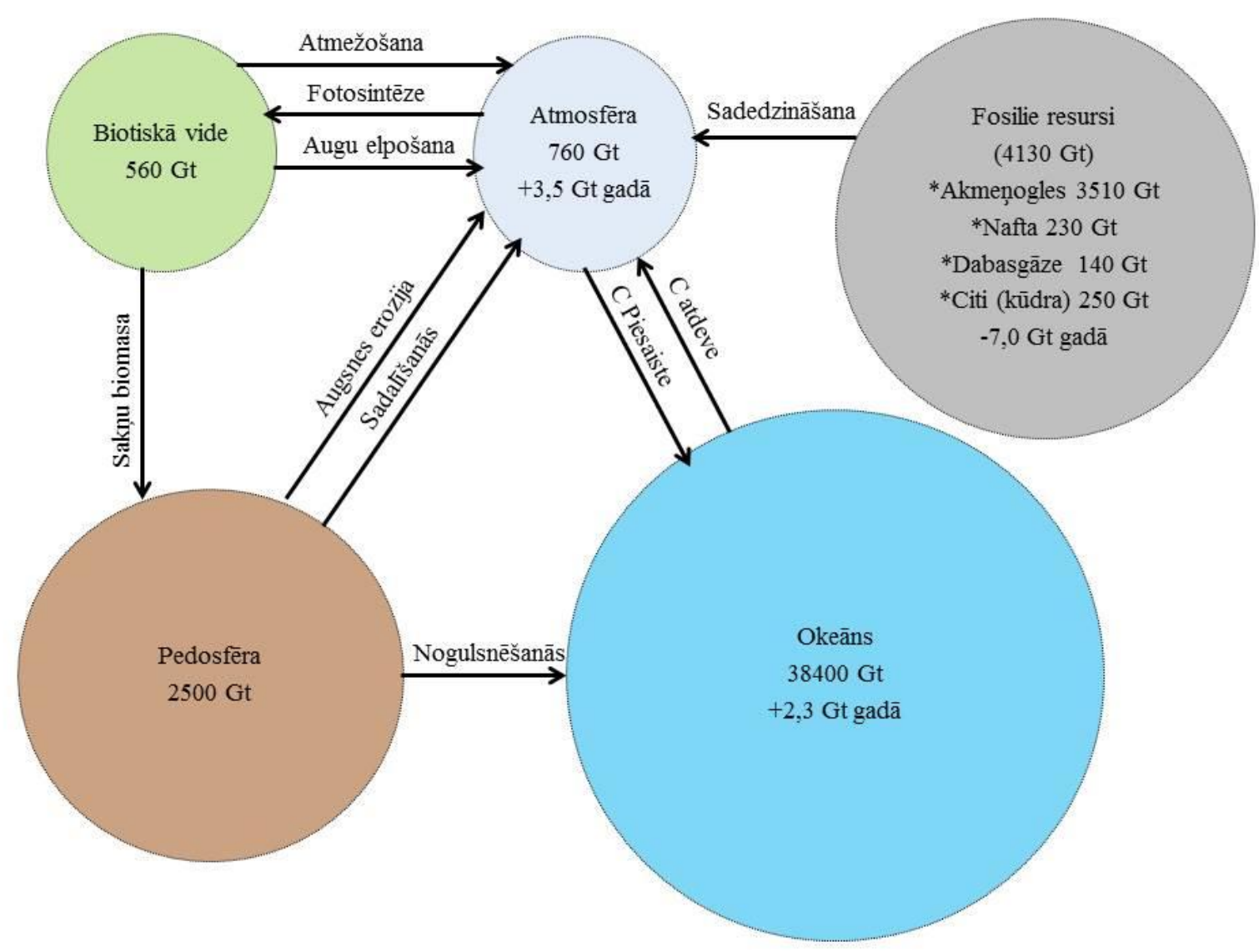

1.1. att. Oglekḷa plūsma starp galvenajām oglekḷa krātuvēm (Lal, 2008)

Starp atmosfēru un biotisko vidi ir lielas grūti aprēķināmas divvirzienu oglekḷa plūsmas, bet no fosilajiem resursiem uz atmosfēru oglekḷa plūsma ir vienvirziena un viegli aprēķināma (Berndes, Bird, \& Cowie, 2011). Oglekḷa daudzuma pieauguma temps atmosfērā lielā mērā ir atkarīgs no antropogēnām darbībām, kā arī no bioǵeoķīmisko un klimatisko procesu mijiedarbības oglekḷa krātuvēs. Daḷa no atmosfērā nonākušā oglekḷa absorbējas okeānos un dzīvajā biomasā, tomēr tā apjomi atmosfērā turpina palielināties, vidēji ar tempu $3.5 \mathrm{Gt}$ oglekḷa gadā. Prognozējams, ka fosilo resursu patēriņš kulmināciju sasniegs 2025. gadā, līdz ar to oglekḷa plūsma uz atmosfēru turpinās palielināties, bet pēc tam būs vairāk vai mazāk konstanta līdz samazināsies fosilo resursu ieguve (Lal, 2008). Sauszemes oglekḷa krātuves (biotiskā vide un pedosfēra) kopā absorbē oglekli apmēram 2-4 Gt gadā un līdz 2050. gadam to piesaistes potenciāls varētu palielināties līdz 5 Gt gadā (Scholes \& Noble, 2001). Oglekḷa piesaistes kapacitāte sauszemes ekosistēmās varētu palielināties caur tā saucamo $\mathrm{CO}_{2}$ mēslošanas efektu (angḷu val. $\mathrm{CO}_{2}$ fertilization effect) (Matthews, 2007) un izmain̄ām zemes lietojuma veidā un apsaimniekošanā. $\mathrm{CO}_{2}$ mēslošanas efekta princips ir vienkāršs: lielāks $\mathrm{CO}_{2}$ daudzums atmosfērā, veicina augu augšanu, nodrošinot arvien lielāku $\mathrm{CO}_{2}$ piesaisti to biomasā.

Sauszemes oglekḷa plūsmas aprēķini uz citām krātuvēm ir mazāk precīzi nekā okeānos, atmosfērā un izlietojot fosilos resursus (Houghton, Hall, \& Goetz, 2009). $\mathrm{CO}_{2}$ emisijas zemes izmantošanas maiņas rezultātā ir neskaidras, jo joprojām nav precīzi zināms, piemēram, tropisko mežu atmežošanas apmērs, kā arī to biomasa (Xue et al., 2017). Arī Eiropas valstu mežu biomasas aprēķinos ir liela nenoteiktība, novērtējot uzkrātā oglekļa apjomus mežaudzēs pat vienas koku sugas ietvaros, kas norāda uz nepieciešamību uzlabot aprēķinu kvalitāti (Neumann et al., 2016). Šobrīd sauszemes oglekḷa uzkrājumu raksturošanas metožu izvēle un tās pilnveidošana ir katras valsts atbildība, tomēr metodikas izstrādāšanas pamatprincipus un noklusētos emisiju faktorus nosaka vadlīnijas, kuru uzdevums ir harmonizēt aprēķinu metodes 
un padarìt rezultātus salīdzināmus. Zinātniski pamatotu aprēķina metožu izstrādāšanai ir būtiska ietekme uz globālās oglekḷa plūsmas aprēķinu ticamību un klimata pārmaiņu mazināšanas politikas mērķu sasniegšanu. Katras valsts lokālo apstākḷu iekḷaušana aprēķinos ļauj būtiski samazināt nenoteiktību un identificēt efektīvākos klimata izmaiņu mazināšanas pasākumus.

\subsubsection{Atmosfēras oglekḷa piesaiste}

Atmosfērā esošā $\mathrm{CO}_{2}$ uztveršanu un uzglabāšanu citās oglekḷa krātuvēs, kas citādi tiktu emitēts atpakal atmosfērā, sauc par oglekḷa piesaisti. Šajā kontekstā, visus oglekḷa piesaistes veidus var iedalīt divās lielās kategorijās - abiotiskie un biotiskie oglekḷa piesaistes paņēmieni (1.2. attēls). Abiotiskie piesaistes paņēmieni balstās uz fizikālām un ķīmiskām reakcijām, kāa arī inženiertehniskām metodēm bez dzīvo organismu (piemēram, augu vai mikroorganismu) iejaukšanās (Lal, 2008). Savukārt, biotisko paņēmienu pamatā ir oglekḷa piesaiste no atmosfēras caur fotosintēzes procesu un turpmāku tā noglabāšanu augsnē un okeānos. Fotosintēzes blakusprodukts ir skābeklis, attiecīgi, mazinoties $\mathrm{CO}_{2}$ piesaistei no atmosfēras, samazinās arī skābekḷa saturs atmosfērā.

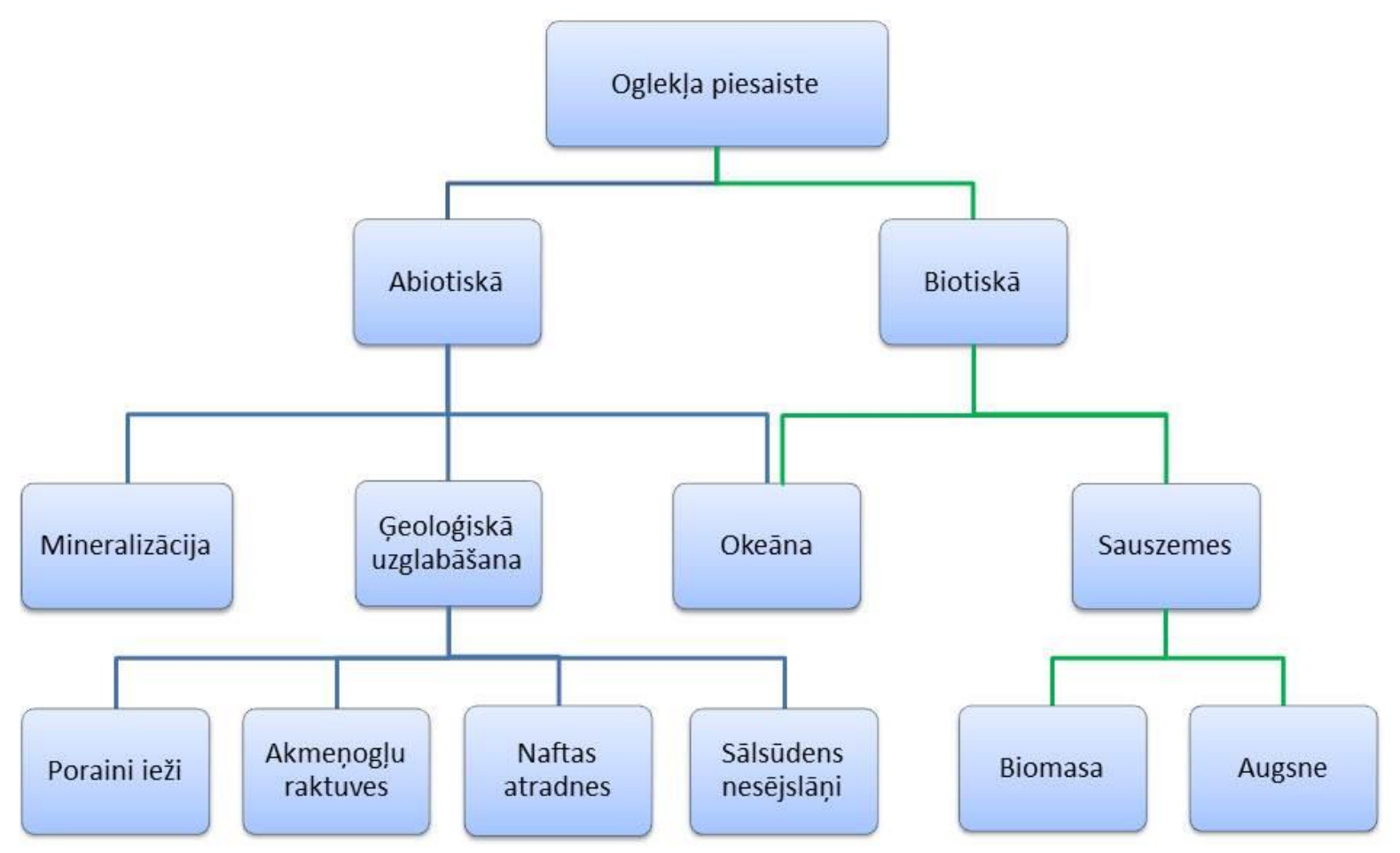

\section{2. att. Potenciālās oglekḷa piesaistes iespējas, balstoties uz literatūrā pieejamo informāciju}

Viena no reālākajām abiotiskajām piesaistes iespējām $\mathrm{CO}_{2}$ koncentrācijas samazināšanai atmosfērā ir tā uztveršana un uzglabāšana zemes dzīlēs vai okeānos. Tas ir process kurā antropogēnas izcelsmes $\mathrm{CO}_{2}$ tiek savākts, tādā veidā nodrošinot gāzes izolāciju no atmosfēras (Boot-Handford et al., 2014; Pires et al., 2011). Uztverto $\mathrm{CO}_{2}$ var iesūknēt izstrādātās akmeņogḷu raktuvēs, naftas urbumos, stabilos iežu slāṇos vai sālsūdens nesējslāṇos (Klara, Srivastava, \& McIlvried, 2003). $\mathrm{CO}_{2}$ iesūknēšana okeānos lielā dziļumā ir alternatīva, kas plaši apspriesta jau apmēram 40 gadus (Lal, 2008). Lielā dzilumā (dzilāk par $1000 \mathrm{~m}$ ) $\mathrm{CO}_{2}$ ir blīvāks nekā ūdens, līdz ar to tas grimst un var tikt uzglabāts okeānu dzīlēs. $\mathrm{CO}_{2}$ piesaistes potenciāls okeānos lēsts $\operatorname{li} \mathrm{dz} 10000 \mathrm{Gt}$, pārsniedzot aprēķinātos fosilo kurināmo 
krājumus (IPCC, 2005) No idejas rašanās septiņdesmito gadu beigās, ir panākts ievērojams progress izmaksu samazināšanas ziņā $\mathrm{CO}_{2}$ uzglabāšanai okeānos, bet joprojām metode vērtējama kā dārga. Rūpnieciskā $\mathrm{CO}_{2}$ uzglabāšana prasa lielu enerǵiju un dārgas iekārtas, kā arī uztvertā gāze ir jātransportē un jāuzglabā stabilos ǵeoloǵiskos veidojumos (Rubin, 2012). Uzglabāšanas izmaksas ir novērtētas apmēram 40-70 eiro par tonnu $\mathrm{CO}_{2}$, atkarībā no pielietotās tehnologijas (Narbel, Hansen, \& Lien, 2014), tāpēc joprojām turpinās darbs pie citu risinājumu meklēšanas. $\mathrm{CO}_{2}$ iesūknēšana ekspluatējamās naftas vai gāzes atradnēs, vienlaikus izspiežot no iežiem fosilos resursus, varētu būt ekonomiski izdevīgāka stratēgija kas vēl jāpilnveido (Lackner, 2003). Citas potenciālās oglekḷa piesaistes iespējas, kuras prezentējuši zinātnieki ir mākslīgās fotosintēzes izvēršana (Meyer, 1989), $\mathrm{CO}_{2}$ pārveidošana geoloǵiski stabilos minerālkarbonātos (Huijgen \& Comans, 2003), kā arī oglekḷa piesaiste okeānos ar aktīvo absorbētāju palīdzību. Tomēr arī iepriekšminētajām metodēm ir augstas izmaksas vai liels risks negatīvi ietekmēt apkārtējo vidi (Royal Society, 2009).

Kopumā abiotiskajai oglekḷa piesaistei okeānos un zemes dzīlēs prognozē lielu potenciālu, jo teorētiski šiem avotiem ir lielāka oglekḷa ietilpība nekā biotiskajai piesaistei (Freund \& Ormerod, 1997). Tomēr tehnologijas mākslīgai oglekḷa noglabāšanai varētu būt plašāk izmantojamas vien pēc 2025. gada, jo šobrīd pieejamās tehnologijas ir dārgas, energoietilpīgas un saistās ar augstu $\mathrm{CO}_{2}$ noplūžu risku. (Lal, 2008). Šì iemesla dēḷ šobrīd pasaulē lielāks uzsvars tiek likts tieši uz biotiskajām oglekḷa piesaistes metodēm, kas vienlaicīgi l̦auj samazināt arī energoresursu patēriṇu un nodrošināt mazāku fosilā kurināmā izmantošanu.

Literatūrā minēta arī cita iespēja, kā dabiskā veidā piesaistît okeānos oglekli ar fotosintēzes palīdzību. Fitoplanktona fotosintēze ir viens no bioloǵiskajiem mehānismiem, kurš gadā piesaista apmēram $45 \mathrm{Gt}$ oglekḷa (Falkowski, 2000). Daļa no fitoplanktona organiskā materiāla nogulsnējas okeāna dzelmē, tādējādi akumulējot oglekli. Dzelzs $(\mathrm{Fe})$ pieejamība ir viens no faktoriem, kas ietekmē fitoplanktona izplatību okeānu ekosistēmās. Tāpēc tiek veikti pētījumi par Fe mēslošanas nozīmi biotiskajā $\mathrm{CO}_{2}$ piesaistē okeānos (Boyd et al., 2004; Martin et al., 1994). N̦emot vērā pašreizējo zināšanu līmeni, joprojām nav skaidrs kā okeānu mēslošana var ietekmēt okeānu ekologiju ilgtermiņā, līdzīgi kā $\mathrm{CO}_{2}$ iesūknēšana (Chisholm, 2001; Williamson et al., 2012).

Mitrāji un to augsnes ir ievērojama krātuve, kas uzglabā apmēram $450 \mathrm{Gt}$ oglekḷa (Warner, Clymo, \& Tolonen, 1993). Kūdras augsnes var saturēt vairāk nekā 200 reizes lielāku oglekḷa daudzumu nekā uz tām augošā veǵetācija (Garnett et al., 2001). Tomēr šādu augšnu nosusināšana un to turpmāka izmantošana vairumā gadījumos padara tās par $\mathrm{CO}_{2}$ emisiju avotu. Lielas mitrāju platības daudzu gadu garumā visā pasaulē ir nosusinātas lauksaimniecības vai mežsaimniecības vajadzībām. Nosusinātās kūdras augsnes sadalās un kūdras biezums samazinās ar ātrumu 1-2 cm gadā, galvenokārt, oksidācijas procesu rezultātā (Leifeld, Müller, \& Fuhrer, 2011; Wosten, Ismail, \& Wijk, 1997). Mitrāju atjaunošana varētu novest pie atgriezeniska procesa un būt oglekḷa piesaistes nevis emisiju avots. Tomēr pēc to atjaunošanas paietu pārāk ilgs laiks, līdz dabisko procesu rezultātā atjaunotās mitrzemes kḷūtu līdzīgas dabiskajām. Zinātnieku pētījumi liecina par to, ka boreālajā un hemiboreālajā mežu joslā, arī pēc nosusināšanas, augsne var darboties kā oglekḷa piesaistītājs nevis emisiju avots (Lohila et al., 2011; Lupikis et al., 2017; Ojanen et al., 2010). Tas nozīmē, ka meža audzēšana šādās platībās nodrošina lielāku oglekḷa ienesi augsnē pārsniedzot oglekḷa emisijas kūdras sadalīšanās rezultātā.

Oglekḷa piesaiste dabisku procesu rezultātā notiek ne tikai mitrāju augsnēs, bet arī citās minerālaugsnēs, papildinot augsnes organiskā un neorganiskā oglekḷa krājumus. Pretstatā geolog̣iskajai piesaistei, kur $\mathrm{CO}_{2}$ mākslīgi iesūknē $1-2 \mathrm{~km}$ dziļumā, augsnes organiskā oglekḷa piesaiste norisinās $0-40 \mathrm{~cm}$ dziļumā dabisku humifikācijas procesu rezultātā. Apstrādātas augsnes parasti satur mazākus oglekl̦a krājumus nekā līdzvērtīgas neapstrādātas augsnes, jo augsnes apstrādes rezultātā notiek augsnē esošā oglekļa emitēšana. Uzsākot iepriekš neapgūtas augsnes apstrādi, visstraujāk organiskais ogleklis, tiek atbrīvots pirmajos 
20-50 gados mērenajos reǵionos un pirmo 5-10 gadu laikā tropiskajos reǵionos (Lal, 2001). Apstrādāta augsne satur apmēram $50-75 \%$ no sākotnējā organiskā oglekḷa apjoma un tā emisiju izraisa oksidēšanās, mineralizācijas, izskalošanās un erozijas procesi (Kumar et al., 2013). Noplicinātu augšņu atjaunošana ir viena no stratēǵijām, lai samazinātu $\mathrm{CO}_{2}$ daudzumu atmosfērā. Organiskā oglekḷa piesaistes potenciāls augsnēs ir novērtēts aptuveni $0.4-1.2 \mathrm{Gt}$ jeb 5-15\% no pasaules fosilo kurināmo emisijām (Lal, 2004). Kūtsmēslu, notekūdeņu dūņu un citu minerālmēslojumu izmantošana lauksaimniecībā ir veids, kā paātrināt un palielināt augsnes oglekḷa piesaisti (Smith et al., 1997), jo augsnes oglekḷa piesaistes apjoms ir cieši saistīts ar augu virszemes dal̦ā un saknēs esošā oglekl̦a izmantošanu humifikācijas procesā. Atšksirībā no augsnes organiskā oglekḷa, neorganiskā oglekḷa piesaistes ātrums ir ievērojami lēnāks un tas notiek sarežǵītu ķīmisku reakciju rezultātā.

Oglekļa uzkrāšana mežos dzīvajā un nedzīvajā biomasā, zemsegā un augsnē, kā arī koksnes produktos jau no klimata pārmainu problēmas pirmsākumiem ir atzîta par efektīvu metodi $\mathrm{CO}_{2}$ samazināšanai atmosfērā neradot negatīvu ietekmi uz vidi (Lal, 2008). Meža ekosistēmās ogleklis uzkrāts ne tikai kokaugu biomasā, bet arī nobirās, augos un augsnē. $\mathrm{CO}_{2}$ mēslošanas efekta rezultātā prognozējams, ka potenciālā oglekḷa piesaiste meža ekosistēmas varētu nākotnē palielināties pie nosacījuma, ja augsnes nodrošinājums ar barības vielām nesamazināsies.

Diskusijas par meža platību un koku ciršanas vecuma palielināšanu joprojām ir aktuālas globālā mērogā. Tiek meklēti jauni starptautiski instrumenti globālai SEG samazināšanai atmosfērā, mēgeinot samazināt mežizstrādes apjomus un kombinējot dažādas zemju apmežošanas un neproduktīvu mežaudžu nomaiņas programmas. Saskaņā ar atsevišksu zinātnieku domām, zemes lietojuma veida maiņa, ieskaitot meža zemes transformāciju, ir viens no galvenajiem iemesliem, kas 21. gadsimtā veicina cilvēces radītas vides problēmas (Petrokofsky et al., 2012). Tikai atmežošana vien izraisa apmēram $12 \%$ no visām SEG emisijām, savukārt vēl $6 \%$ rada kūdras oksidēšanās nosusināšanas rezultātā un ugunsgrēki kūdras atradnēs (Werf et al., 2009). Daļēji zemes lietojuma maiņas rezultātā izraisīto meža platību samazināšanos tropiskajos reǵionos kompensē meža platību palielināšanās mērenajā un boreālajā joslā (Ni et al., 2016). Apmežošanas pretinieki gan apgalvo, ka liela mēroga atklātu vietu apmežošanai var būt arī negatīva kopējā ietekme uz klimatu, jo tiks samazināts zemes albedo (Unger, 2014) vai arī būtiski tiks ietekmēta ūdens plūsma, kā arī palielināsies augsnes sasāļošanās un paskābināšanās (Jackson, 2005). Albedo ir saules radiācijas daļa, ko atstaro zemes virma atpakaļ atmosfērā. Tādējādi, apsverot plaša mēroga apmežošanas pasākumus, būtu jāṇem vērā arī procesa negatīvā ietekme uz ūdens pieejamību un albedo izmaiņām. Risinājums varētu būt izaudzētās koksnes novākšana un ilglaicīga uzglabāšana zem zemes, tādējādi noglabājot koksnē saistîto oglekli. Šāda stratēgija, pamatojoties uz minēto ideju, tika ieteikta vairākus gadus iepriekš (Köhl \& Frühwald, 2009; Zeng, 2008).

Sausa koksne satur apmēram 50\% oglekḷa un koksne varētu tikt noglabāta uz ilgu laiku, piemēram, izstrādātās ogḷ raktuvēs vai speciālās uzglabāšanas vietās netālu no mežiem (Ni et al., 2016). Analizējot ieteiktās metodes, oglekḷa noglabāšana ēkās un mēbelēs tomēr ir lētāks un saprātīgāks paṇēmiens. İpaši pēdējos gados pieaug uzsvars par $\mathrm{CO}_{2}$ emisiju samazināšanu ēku būvniecībā un atrodot koksnei arvien jaunus pielietojumus, kā arī pilnveidojot tās apstrādes tehnoloğijas (Cabeza et al., 2013; Gustavsson, Pingoud, \& Sathre, 2006). Novērtēts, ka oglekļa uzglabāšanas teorētiskais potenciāls koksnes produktos vai koksnes krātuvēs globālā mērogā varētu būt 5-15 Gt oglekḷa gadā (Zeng, 2008). Reālais potenciāls gan varētu būt ievērojami mazāks, jo pasaulē pastāv daudz un dažādi mežsaimnieciskās darbības ierobežojumi kuri limitē pieejamos koksnes resursus. Klimata pārmaiņu starpvaldību padome (IPCC) deviņdesmitajos gados novērtējusi neto oglekḷa piesaisti sauszemes ekosistēmās apmēram 1-2.6 Gt oglekḷa gadā. Jaunākos pētījumos, izmantojot meža inventarizāciju datus un jaunākos secinājumus par oglekḷa apriti ekosistēmās, oglekḷa piesaiste novērtēta vidēji 2.4 $\pm 0.4 \mathrm{Gt}$ gadā, bet piesaistes lielums katru gadu ir mainīgs (Pan et al., 2011). Dēl nenoteiktības un oglekḷa piesaistes izmaiņām laika gaitā, ārkārt̄̄gi svarīgi ir veikt precīzus 
oglekḷa piesaistes aprēķinus, lai pieņemtu nepieciešamos lēmumus klimata pārmaiņu mazināšanas pasākumos.

\subsubsection{Oglekḷa uzskaites aktualitāte}

SEG uzskaites nozīme pasaules attīstītajās valstīs ir aktualizējusies, kopš starptautiskā mērogā ir uzsākta cīṇa pret straujām klimata pārmaiņām. 1997. gada 11. decembrī piennemts Kioto protokols, kas pievienots UNFCCC un ir viens no svarīgākajiem starptautiskajiem juridiskajiem instrumentiem, kas šobrīd nosaka mērķus un metodes cinnai pret klimata izmaiņām. Lai protokols kḷūtu izpildāms, tas bija jāratificē pietiekamam skaitam pasaules valstu, kuru radītās emisijas pārsniedz $55 \%$ no pasaules $\mathrm{CO}_{2}$ emisijām (Breidenich et al., 1998). Amerikas Savienoto Valstu radīto emisiju īpatsvars ir 36.1\% no kopējām pasaules emisijām, tomēr šì valsts atteicās parakstīt Kioto protokolu un vēlāk izstājās no līguma. Tikai tad, kad Krievijas Federācija, kuras emisiju īpatsvars bija 17.4\%, parakstot protokolu kḷuva par dalībvalsti, tas 2005. gada 16. februārī varēja stāties spēkā (Beijere et al., 2006).

Kioto protokola un UNFCCC uzdevumi ir ierobežot un samazināt sešu galveno SEG (oglekļa dioksīds $\mathrm{CO}_{2}$, metāns $\mathrm{CH}_{4}$, dislāpekḷa oksīds $\mathrm{N}_{2} \mathrm{O}$, fluoroglūūdeņraži $\mathrm{HFC}$, perfluorogḷūdeņraži $\mathrm{PFC}$, sēra heksafluorīds $\mathrm{SF}_{6}$ ) plūsmu uz atmosfēru, kā arī palielināt $\mathrm{CO}_{2}$ piesaisti oglekḷa krātuvēs. Gadu gaitā daudzu dalībvalstu politiskā griba Kioto protokola ietvaros ir būtiski vājinājusies. To veicināja arī grūtības globālā mērogā izstrādāt vienotu emisiju samazināšanas politiku, jo dalībvalstu viedoķ̣i bija ļoti atšķirīgi (Gren \& Zeleke, 2016). Likumprojekti, kas vienas dalībvalsts tautsaimniecībai neradīja būtisku ietekmi, citām dalībvalstīm radīja lielu ietekmi uz to ekonomiku. IPCC secināja, ka ar SEG emisiju samazināšanu attīstītajās valstīs būs par maz, lai sasniegtu sākotnēji izvirzìtos mērksus, turklāt strauji augošās ekonomikas kā K̦īna un Indija radīja arvien lielākas SEG emisijas. Pēc pirmā Kioto protokola saistību perioda beigām 2012. gadā izrādījās neiespējami izvirzīt un apspriest jaunus emisiju samazināšanas plānus ar tādām lielām valstīm kā Japānu, Jaunzēlandi un Krievijas Federāciju, kamēr Kanāda un Amerikas Savienotās valstis Kioto protokolu nemaz nebija ratificējušas (Savaresi, 2016).

Kopš cīnas uzsākšanas pret klimata pārmaiṇām, SEG emisijas pasaulē ir tikai augušas un sasniegušas līdz šim augstāko līmeni (Grassi et al., 2017). Iepriekšminētā situācija ir atstājusi Eiropas Savienību un citas valstis, kā piemēram, Austrāliju, Norvēg̣iju un Šveici neizdevīgā pozīcijāa, kā vien̄̄gās protokola līgumslēdzējas puses ar reāliem emisiju samazināšanās mērksiem (Savaresi, 2016). Eiropas Savienība ir apñēmusies līdz 2020. gadam samazināt kopējo SEG emisiju apjomu vismaz par 20\%, salīdzinot ar 1990. gada līmeni un uzņemties saistības par samazinājumu pat par 30\%, ja citas rūpnieciskās valstis piekritīs rīkoties līdzīgi. Lai panāktu šāda līmeņa emisiju samazinājumu, tika nosprausti mērķi līdz 2020. gadam uzlabot energoefektivitāti par $20 \%$, palielināt atjaunojamās enerğijas īpatsvaru par $20 \%$ un panākt, lai 10\% transportlīdzekḷlos izmantotās degvielas būtu biodegviela. Kḷuva skaidrs, ka, lai turpmāk novērstu klimata pārmaiņas, veicinātu pāreju uz oglekḷa mazietilpīgu un pret klimata pārmaiņām noturīgu attīstību, ir nepieciešama jauna vienošanās, aizstājot Kioto protokolu.

Pēc ilgām diskusijām 2015. gada 12. decembrī 195 pasaules valstu vienbalsīgi apstiprinātais Parīzes nolīgums ir līdz šim nozīmīgākā starptautiskā vienošanās, kuras mērķis ir izvairīties no sekām, ko rada klimata izmainas (Grassi et al., 2017). Parīzes nolīgums 2020. gadā aizstās Kioto protokolu un tā galvenais mērķis būs noturēt globālās temperatūras pieaugumu zem $2{ }^{\circ} \mathrm{C}$ salīdzinot ar pirms rūpniecības laikmeta vidējo temperatūru (Rogelj et al., 2016) un censties ierobežot temperatūras pieaugumu $1.5^{\circ} \mathrm{C}$ robežās (Hulme, 2016). Nolīgumā īpaši tiek uzsvērta negatīvā atmežošanas un noplicinošas meža apsaimniekošanas ietekme kopējā $\mathrm{CO}_{2}$ emisiju samazināšanā. Latvija Parīzes nolīguma ratifikāciju apstiprināja 2017. gada 9. februārī un tā nosacījumus - samazināt Eiropas Savienības SEG emisijas par 
vismaz 40\% līdz 2030. gadam, īstenos kopīgi ar pārējām dalībvalstīm. Parīzes nolīguma izvirzītie mērķi ir l̦oti ambiciozi; lai noturētu globālās temperatūras pieaugumu zem $2{ }^{\circ} \mathrm{C}$, ikgadējās $\mathrm{CO}_{2}$ emisijas jāsamazina no pašreizējā līmeņa $10 \mathrm{Gt}$ oglekḷa gadā līdz 5-6 Gt oglekḷa 2050. gadā (Ni et al., 2016). Kaut gan sauszemes un okeāna oglekḷa krātuvēs tiek absorbēts apmēram $60 \%$ no kopējo $\mathrm{CO}_{2}$ emisiju apjoma, tomēr piesaistes àtrums un kapacitāte nav pietiekama, lai asimilētu visus plānotos antropogēnos $\mathrm{CO}_{2}$ izmešus 21 . gadsimtā ja turpmāk netiks krasi ierobežota fosilo resursu izmantošana (Lal, 2008).

Lai būtu iespējams izvērtēt mežsaimniecības sektora ieguldījumu, katrai valstij 2011. gadā aprēķināts SEG emisiju samazināšanas un piesaistes palielināšanas mērķis jeb tā saucamais meža apsaimniekošanas references līmenis (anglu val. forest management reference level vai forest reference emission level). UNFCCC noteiktais references lìmenis ir oglekḷa emisiju robežvērtība, pret kuru iespējams novērtēt valsts mežsaimniecības sektora ieguldījumu emisiju samazināšanā. Latvijai, kā arī vairākām citām dalībvalstīm, kurām nebija pieejama nacionālā aprēķinu metodika, meža apsaimniekošanas references līmeni aprēķināja komisijas pētniecības centrs. Mūsu valstij sākotnēji tika apstiprināts ļoti ambiciozs references līmenis (-16 302 mlj.t $\mathrm{CO}_{2}$ ekvivalenti gadā) un bija augsts risks, ka šo mērķi nebūs iespējams sasniegt, ņemot vērā ka mežam jāapmierina arī sabiedrības sociālās un ekonomiskās funkcijas. Dalībvalstīm bija tiesības nepaļauties uz komisijas aprēķiniem un izstrādāt arī savas nacionālās metodikas references līmeņa precizēšanai. Metodikas pilnveidošanas rezultātā, izmantojot daudz korektākus nacionālā meža resursu monitoringa (MRM) datus, promocijas darbā izstrādātos biomasas vienādojumus (Liepiņš, Lazdiņš, \& Liepiṇšs, 2017) un citus uzlabojumus, Latvijas meža apsaimniekošanas saistību apmērs no 2014.-2020. gadam samazināsies zem 4000 mlj.t. $\mathrm{CO}_{2}$ gadā. Četrkārtīgā atšķirība starp Eiropas Komisijas ekspertu izstrādāto meža apsaimniekošanas references līmeni un aprēķinu rezultātiem, kas balstīti uz Latvijā pārbaudītiem pieņēmumiem, norāda uz ārkārtīgi būtisku nacionālo metožu un aprēksinu lomu SEG emisiju uzskaitē un prognozēšanā.

Parīzes nolīgums nosaka, ka dalībvalstīm arī pēc 2020. gada būs jānosaka meža apsaimniekošanas references līmenis, kurš noteiks mežsaimniecības radīto SEG emisiju un $\mathrm{CO}_{2}$ piesaistes robežvērtības no 2021.-2025. un 2026.-2030. gadiem (Sasaki et al., 2016). Eiropas Komisijā turpinās darbs pie dalībvalstu nacionālā mežsaimniecības uzskaites plāna izstrādes (angḷu val. national forestry accounting plan) kurā tām būs jāpamato noteiktais meža apsaimniekošanas references līmenis. Lai Latvija spētu aizstāvēt savas pozīcijas, ir nepieciešami ne vien zinātniski pētījumi par risinājumiem emisiju mazināšanai un to uzskaites metožu pilnveidošanai, bet arī diplomātiski jāspēj pamatot Latvijas intereses Eiropas līmenī.

Viens no mehānismiem $\mathrm{CO}_{2}$ emisijas samazināšanai atmosfērā ir emisiju kvotu tirdzniecības sistēma (ETS). Viena emisijas kvota ir aţ̦auja emitēt 1 tonnu $\mathrm{CO}_{2}$ izmešu. Eiropas Savienības iekšējā ETS ir lielākais oglekḷa tirgus pasaulē (Fan et al., 2017) un līdz šim organizēta trijos pārskata periodos (Cretí \& Joëts, 2017). Pirmajā pārskata periodā, kas norisinājās no 2005.-2007. gadam, visas emisiju kvotas tika piešķirtas bez maksas, radot iespaidīgu emisijas kvotu pārpalikumu, ko vēlāk nācās anulēt. Arī nākamajā pārskata periodā no 2008.-2012. gadam kvotas piešksīra bez maksas, tomēr ar nelielu rezervi, ko Eiropas Komisija vēlāk pārdeva izsolē tām valstīm kuras saistības nevarēja izpildīt. No 2013. gada sācies nākamais ETS periods, kas noslēgsies 2020. gadā. Arī trešajā periodā tika nolemts, ka daļu kvotu dalībvalstīm jāpiešksir bez maksas, bet pārējām jānonāk izsolēs. Vairāk nekā 40\% no tirgū pieejamajām emisiju kvotām tiek izsolītas elektroenerǵijas nozarē un š̄ daļa katru gadu pieaug (European Comission, 2017). Kopumā Eiropas Savienības ETS sistēma nav devusi sākotnēji gaidīto rezultātu (Cretí \& Joëts, 2017). Zemās emisijas kvotu cenas nav motivējušas samazināt kaitīgo $\mathrm{CO}_{2}$ emisiju nonākšanu atmosfērā. Nepieciešamība mainīt esošo situāciju ETS novedusi pie reformām, kas stāsies spēkā nākamajos gados. Reformu rezultātā pieaugs $\mathrm{CO}_{2}$ emisiju cena, kas ietekmēs visus iedzīvotājus un uzṇēmumus Eiropas Savienībā. Paredzams, ka pieaugot emisiju vienību cenai, notiks neizbēgams elektroenerğijas cenu kāpums, jo tieši š̄i nozare ir galvenais emisiju kvotu pircējs. 
Atbilstoši UNFCCC prasībām, dalībvalstīm, t.sk. Latvijai, katru gadu ir jāsniedz pārskats par SEG emisijām un $\mathrm{CO}_{2}$ piesaisti, kā arī noteiktajos termiņos jāsagatavo nacionālie ziņojumi atbilstoši IPCC definētajām vadlīnijām (Gasparini \& Cosmo, 2015; Grassi et al., 2017). Ziņojumos jāsniedz informācija ne tikai par SEG emisijām un $\mathrm{CO}_{2}$ piesaisti, bet arī par UNFCCC saistību īstenošanai veiktajiem un iecerētajiem politiskajiem risinājumiem (Eggleston et al., 2006; IPCC, 2003). Pēc veiksmīgas Eiropas Savienības emisiju samazināšanas mērķu sasniegšanas otrajā pārskata periodā (2008.-2012 gads), turpmākie Eiropas Savienības izvirzītie mērksi ir daudz ambiciozāki, tajā skaitā arī attiecībā uz meža apsaimniekošanu.

Kamēr atmežošana ir galvenais SEG emisiju avots tropu mežos, lielākais piesaistītā oglekl̦a apjoms notiek mērenajos un boreālajos mežos (Pan et al., 2011). Latvija un Igaunija, lielākā daļa Lietuvas, Baltkrievijas ziemel̦u daļa un Zviedrijas dienvidu reǵioni pēc teritoriālā novietojuma atrodas Eiropas hemiboreālajā mežu joslā (Ahti et al., 1968), kas izvietota starp mēreno un boreālo joslu (1.3. attēls). Vadlīnijās (Eggleston et al., 2006) Latvijai tiek piedāvāti mērenās mežu joslas biomasas un līdz ar to oglekḷa aprēķinu un pārrēķinu koeficienti, kurus ieteikts pielietot arī tādām Eiropas valstīm kā Horvātija, Bulgārija un Serbija. Šo pārrēķina koeficientu lietošana Latvijas mežos var radīt ievērojamu uzkrātā oglekḷa pārvērtěšanas risku. Vairāki zinātnieki ir pētījuši koku virszemes biomasas variēšanu atkarībā no ǵeogrāfiskā novietojuma, veǵetācijas zonām, ūdens deficīta, vidējās temperatūras un citiem faktoriem (Berninger et al., 1995; Stegen et al., 2011; Wirth et al., 2004). Dažādu klimatisko faktoru kompleksās iedarbības rezultātā mežaudžu krājai, līdz ar to arī kokos uzkrātā oglekḷa apjomam, Eiropā ir tendence palielināties virzienā no ziemeļu platuma grādiem uz dienvidiem.

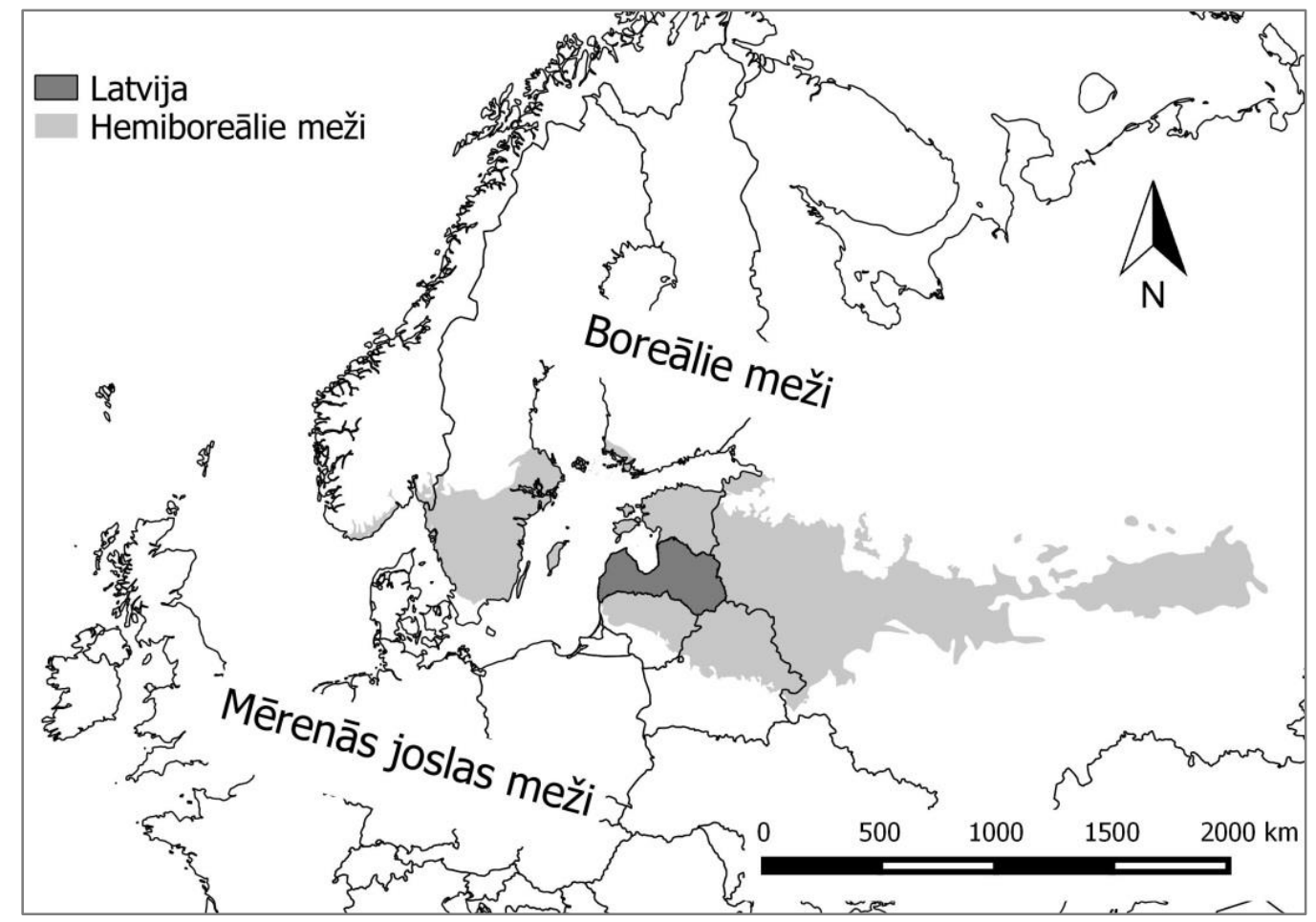

\section{3. att. Latvijas atrašanās vieta hemiboreālo mežu joslā pēc Ahti, Hämet-Ahti, \& Jalas, (1968) un EEA (2007)}

Pirmos Kioto protokola saistību gadus $\mathrm{CO}_{2}$ piesaiste tika rēķināta vienkāršoti, izmantojot IPCC izstrādātos noklusētos pārrēksinu koeficientus. 2011. gadā Latvijas Valsts mežzinātnes institūts "Silava" uzsāka AS "LVM" un SIA "MKPC" finansētu projektu par mežsaimniecisko darbību ietekmi uz SEG emisijām un oglekḷa piesaisti. Projekts noslēdzās 2015. gadā un tā ietvaros izstrādātie matemātiskie instrumenti l̦āva būtiski uzlabot kokaudžu 
$\mathrm{CO}_{2}$ piesaistes aprēķinu metodiku piemērojot Latvijas teritorijai atbilstošākus pārrēķinu koeficientus, nevis vadlīnijās minētos, izvairoties no būtiska oglekḷa apjoma koksnes biomasā pārvērtēšanas riska.

Koksnes biomasa mežaudzēs Latvijā ir viens no $\mathrm{CO}_{2}$ piesaistes pamatavotiem, tāpēc, atbilstoši starptautiskajām SEG inventarizācijas ziņojuma sastādīšanas vadlīnijām, Latvijā vairs nedrīkst izmantot vadlīnijās iekļautos biomasas pārrēķinu koeficientus, bet ir jāizstrādā zinātniski pamatota un aprobēta metodika oglekḷa apjoma koksnes biomasā novērtēšanai, tajā skaitā, vienādojumi koku biomasas noteikšanai. Latvijā mežs ir vien̄̄gā ZIZIMM sektora kategorija, kur oglekļa piesaiste pārsniedz SEG emisijas. Saskaņā ar nacionālo SEG inventarizācijas ziņojuma datiem ik gadu koku biomasā tiek piesaistîts apmēram 32 milj.t $\mathrm{CO}_{2}$, protams, daļa no tā nonāk atpakal̦ atmosfērā mežizstrādes un citu procesu rezultātā. Rēķinot uz platības vienību, ikgadējā Latvijas mežu oglekḷa piesaiste ir ievērojama pat visas Eiropas mērogā, tāpēc ir svarīgi, lai mēs to spētu novērtēt maksimāli precīzi.

\subsection{Kokaudžu biomasas novērtēšanas metodes}

Vadoties pēc Eggleston et al. (2006) klasifikācijas, meža ekosistēmā piecas galvenās oglekḷa krātuves ir stumbra un zaru biomasa, sakņu biomasa, nobiras, kritalas un organiskās vielas augsnē. Fotosintēzes procesā augos uzṇemtais ogleklis nepārtraukti pārvietojas starp šīm oglekļa krātuvēm. Vislielākais piesaistītā oglekḷa apjoms ir akumulēts kokaugu virszemes biomasā, kas ir vissvarīgākā un redzamākā no minētajām sauszemes oglekḷa krātuvēm (Ravindranath \& Ostwald, 2008b). Sakņu biomasas, jeb visu dzīvo sakṇu galvenā funkcija globālajā oglekḷa aprites ciklā ir tā nogādāšana un uzglabāšana augsnē (Eggleston et al., 2006). Nobiru un kritalu kopējā masa sastāda vien nelielu īpatsvaru no kopējā, mežaudzēs akumulētā oglekḷa apjoma, tāpēc tai ir neliels īpatsvars kopējā oglekḷa bilancē (Ravindranath \& Ostwald, 2008b). Arī organiskā augsne ir nozīmīga oglekḷa krātuve mežā, bet oglekḷa piesaiste augsnē, tāpat kā nobirās un kritalās akumulētais ogleklis ir tiešā mērā atkarīgs no augu virszemes un sakņu daļas biomasas (Kumar, Pandey, \& Pandey, 2006; Lal, 2005). Tāpēc koku biomasas novērtěšana ir priekšnoteikums, lai varētu apzināt nobirās, kritalās un augsnē akumulēto oglekḷa apjomus.

\subsubsection{Virszemes biomasas novērtēšana}

Koku virszemes biomasa ietver vairākas biomasas frakcijas, kuras nepieciešams noteikt atsevišķi: stumbra koksne, stumbra miza, sausie zari, dzīvie zari, lapas vai skujas (Eggleston et al., 2006; Ravindranath \& Ostwald, 2008b). Novērtējot kokaudzēs saistītā oglekḷa apjomus, vairumā gadījumos zinātnieki biomasas frakciju skaitu samazina, piemēram, stumbra koksnes masa tiek noteikta kopā ar mizu, iegūstot uzreiz visa stumbra biomasu. Arī skujkoku dzīvajiem zariem ļoti bieži pieskaita klāt skuju un čiekuru masu. Nedaudz savādāk ir ar lapkokiem, jo, mērot zaru biomasu koku bezlapu periodā, lapu masa netiek iekḷauta aprēķinos.

Ir pieejamas divas empīrisko datu ievākšanas metodes koku virszemes biomasas novērtēšanai. Pirmā metode, saukta arī par destruktīvo metodi (anglu val. destructive method vai harvest method) ir izvēlēto paraugkoku vai visu koku nozāgēěana noteiktā platībā. No visām koku biomasas aprēķina metodēm destruktīvā metode ir visprecīzākā, tomēr arī dārgākā un darbietilpīgākā (Gibbs et al., 2007). Metodes pamatā ir atsevišķu koku frakciju stumbra un zaru atdalīšana, svēršana vai tilpuma aprēķināšana un reprezentatīvu paraugu ievākšana absolūti sausas biomasas aprēķināšanai. Metodes ierobežojumi ir tādi, ka tā ir piemērojama tikai nelielām platībām, vai atsevišksu koku biomasas noteikšanai. Minēto metodi galvenokārt pielieto izstrādājot alometriskos vienādojumus, kurus, savukārt piemēro biomasas novērtēšanai plašākā mērogā (Blujdea et al., 2012; Bronisz et al., 2016; Jerome 
Chave et al., 2014; Cienciala et al., 2006; Jenkins et al., 2003; Johansson, 2007; Marklund, 1988; Mugasha et al., 2013; Repola, 2008, 2009; Smith et al., 2014; Zianis et al., 2005).

Pretēji iepriekšējai, otra biomasas novērtěšanas metode , paredz biomasas aprēķināšanu bez koku neiznīcināšanas jeb nozāǵēěsanas (anglu val. non-destructive method). Metode piemērojama meža ekosistēmām, kurās aug retas vai aizsargājamas koku sugas un šādu koku nozāgeěšana nav iespējama vai piel̦aujama, vai arī, novērtējot biomasu plašākā mērogā. Piemēram, Montès et al. (2000) izstrādāja metodi Juniperus thurifera L. biomasas novērtēšanai Marokas dienvidos. Pētījumā individuālu koku biomasu novērtēja, datorizēti rekonstruējot koka formu un vainagu (pēc divām uzņemtām fotogrāfijām noteiktos leņ̧̧̧os), tad, izmantojot katra koka frakciju (stumbrs, zari, lapas) tilpuma un blīvuma datus, aprēķināja koka biomasu. Cits veids kā nedestruktīvi novērtēt virszemes biomasu, ir kāpt kokos un mērīt zaru vai stumbra diametrus noteiktās vietās un augstumos (Aboal, Arévalo, \& Fernández, 2005), vai arī vienkārši nomērīt krūšaugstuma caurmēru, koka augstumu, koka tilpumu, blīvumu un, pielietojot alometriskos vienādojumus, aprēķināt biomasu (Ravindranath \& Ostwald, 2008b). Lai gan šīs metodes raksturojamas kā saudzīgākas, tomēr atsevišķ ku koku nozāgeēšana un nosvēršana pēc destruktīvās metodes ir nepieciešama, lai pārbaudītu izstrādātās metodes precizitāti. No visām koku biomasas novērtēšanas metodēm, alometrisko vienādojumu pielietošana, ir visizplatītākā metode.

Pēc Breu, Guggenbichler, \& Wollmann (2012) ieteikumiem, koku virszemes biomasas novērtēšanai pēc destruktīvās metodes vajadzētu būt organizētai secīgi izpildot septiņas darbības (1.4. attēls).

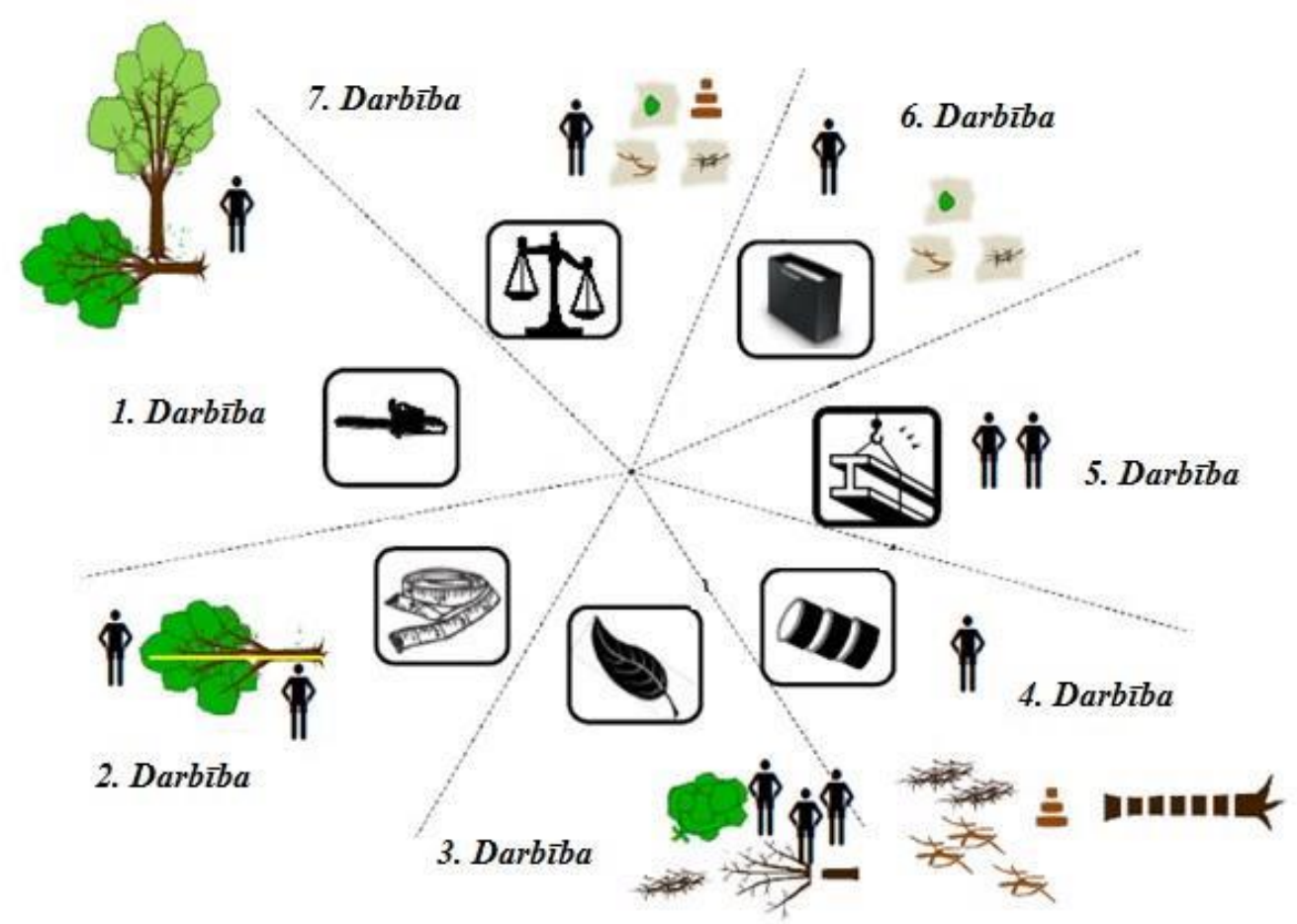

\section{4. att. Veicamās darbības novērtējot kokaugu virszemes biomasu pēc Breu, Guggenbichler, \& Wollmann (2012)}

1. darbība ir darba vietas sagatavošana un koka nozāgeěšana. Pirms koka nozāgeěšanas noteikti uz augoša koka ir jāatzīmē krūšaugstums, lai būtu atskaites punkts stumbra garuma mērījumiem. 2. darbība sevī ietver iepriekš plānoto koka parametru uzmērīšanu un stumbra šķērsgriezuma vietu atzīmēšanu. 3. darbība ir stumbra atzarošana, sauso un dzīvo zaru sašķirošana un, ja paredzēta, tad arī zaru atlapošana. 4. darbībā koka stumbrs optimālākajā variantā tiek sazāgeêts $1 \mathrm{~m}$ vai $2 \mathrm{~m}$ garos nogriežnos jeb sekcijās, kā arī tiek izzāgeêtas koka šķērsgriezuma ripas. 5. darbībā tiek nosvērtas koka stumbra sekcijas (kopā ar attiecīgajām 
šķērsgriezuma ripām), kā arī atsevišķi dzīvo un sauso zaru masa. Visvienkāršāk svēršanu veikt ar iekaramajiem svariem un uz vietas konstruētu atbalsta statīivu svaru iekāršanai, vai arī uzliekot svarus uz traktora strēles, bet tad ir jānodrošina laba piebraukšana objektam. 6. darbība ir attiecināma uz paredzēto stumbra un zaru paraugu (piemēram mitruma, blīvuma) ievākšanu, sagatavošanu un marķēšanu. 7. darbībā, lai samazinātu kḷūdu rašanos, rekomendē turpat lauka apstākļos visus mitruma paraugus nosvērt un tikai tad iepakot līdzņemšanai. Gadījumos, kad to nav uzreiz iespējams izdarīt, mitruma paraugi ir jānosver uzreiz pēc to nogādāšanas laboratorijā.

\subsubsection{Sakṇu un celma biomasas novērtēšana}

Liels oglekļa īpatsvars, ko kokaugi asimilē fotosintēzes laikā, tiek novadīts uz koka daļu kas atrodas augsnē jeb koka saknēs (Litton, Raich, \& Ryan, 2007). Noteiktos augšanas apstākḷos, sakņu biomasā piesaistītā oglekḷa apjoms, var pat pārsniegt koka virszemes biomasā akumulētā oglekḷa apjomu (Mosera et al., 2010). Visbiežāk tomēr sakṇu biomasas īpatsvars kokiem sastāda apmēram 20-26\% no kopējās biomasas (Ravindranath \& Ostwald, 2008a). Boreālās un mērenās joslas mežos koka saknes visvairāk ir izvietotas augsnes virskārtā; pirmajos $30 \mathrm{~cm}$ no augsnes virskārtas ir izvietots $80-90 \%$ no visām saknēm (Jackson et al., 1996). Neskatoties uz to, ka koku sakṇu biomasai ir būtiska ietekme uz augsnes veidošanās procesiem un mežaudžu oglekḷa bilanci, tā joprojām ir ļoti maz pētīta, salīdzinot ar koku virszemes daļu. Lielākā daļa publicēto biomasas vienādojumu izstrādāti, lai noteiktu virszemes biomasu, jo reprezentatīvu sakṇu biomasas datu iegūšana ir daudz dārgāka un laikietilpīgāka (Varik et al., 2013; Weiskittel et al., 2015).

Līdzịgi kā koku virszemes biomasa, arī sakṇu biomasa sastāv no vairākām biomasas frakcijām. Koku rupjās saknes (ang̣̦u val. coarse roots) un uzsūcošās saknes (angḷu val. fine roots) veido galveno sakṇu biomasas dal̦u un tām ir svarīga nozīme kopējā oglekḷa un barības vielu aprites ciklā (Clark et al., 2001; Malhi et al., 2009; Smyth et al., 2013). Uzsūcošās saknes (saknes ar diametru mazāku par $2 \mathrm{~mm}$ ) bieži tiek izslēgtas no sakṇu biomasas aprēķiniem, jo tās praktiski nevar empīriski atdalīt no organiskās augsnes (Ravindranath \& Ostwald, 2008a). Koka celms, kurš sastāv no virszemes un augsnē esošās monolītās, atsevišksās saknēs nediferencētās dal̦as (Liepa \& Blija, 2008) parasti tiek pieskaitīts pie sakņu biomasas, tomēr celma daļa dažādos pētījumos var tikt definēta atšķirīigi. Diskutabls ir jautājums par vietu, kur beidzas koka virszemes un sākas sakṇu biomasa. Teorētiķi uzskata, ka koka virszemes biomasa sākas līdz ar augsnes virsmu, bet praktiski šādā augstumā koka stumbru biomasas mērījumiem sagatavot ir ļoti grūti, īpaši, ja koks sasniedzis lielas dimensijas. Tāpēc praksē kā vietu, kur sadalās virszemes un celma/sakņu biomasas, visbiežāk izmanto noteiktu celma augstumu, kuru vai nu nosaka zināmā attālumā no zemes virsmas (Albert et al., 2014; Johansson, 2002; Mugasha et al., 2013) vai proporcionāli koka augstumam (Marklund, 1988; Repola, 2008, 2009; Smith et al., 2014).

Celma/sakṇu biomasas novērtēšanas paṇēmienus var grupēt tiešās un netiešās metodēs. Pielietojot tiešās novērtēšanas metodes, tiek traucēta turpmāka koka augšana, turpretim netiešās metodes kokam ir nekaitīgas. Zinātniskajā literatūrā joprojām nav vienprātības par to, kā vislabāk novērtēt sakṇu biomasu (Levillain et al., 2011; Milchunas, 2012; Vogt, Vogt, \& Bloomfield, 1998; Yuan \& Chen, 2012). Piemēram, pētījumā, kurā salīdzinātas uzsūcošo sakṇu novērtēšanas metodes, Yuan \& Chen (2012) pielietojot netiešās metodes konstatēja ievērojami lielāku sakņu apjomu salīdzinot ar tiešo metožu pielietošanu, kas ir pretrunā ar citiem pētījumiem, kuros apgalvots, ka rezultāti neatšksiras atkarībā no šo divu metožu pielietojuma (Finér et al., 2011; Vogt et al., 1998). Vienprātības trūkums starp pētniekiem apliecina, ka nepieciešams kritiski izvērtēt katras metodes stiprās un vājās puses, un, vadoties pēc pieejamajiem resursiem (darbaspēka pieejamība, pieejamais finansējums, vietas īpatnības, 
kā arī citi ierobežojumi), jāizvēlas sākotnēji izvirzītajiem pētījuma mērḳiem vispiemērotākā metode.

Addo-Danso et al. (2016) ir apkopojuši un vērtējuši visbiežāk izmantotās celma/sakṇu biomasas novērtēšanas metodes balstoties uz iepriekš definētiem kritērijiem (1.1. tabula).

1.1. tabula

Celma/sakṇu biomasas novērtēšanas metodes (Addo-Danso et al., 2016)

\begin{tabular}{|c|c|c|c|c|c|}
\hline \multicolumn{2}{|l|}{ Metode } & Darbības princips & \begin{tabular}{|l} 
Precizitātes \\
prasības
\end{tabular} & Izmaksas & Precizitāte \\
\hline \multicolumn{6}{|c|}{ Rupjo sakn̦u biomasa } \\
\hline $\begin{array}{l}\text { Sakṇu } \\
\text { sistēmas } \\
\text { izrakšana } \\
\end{array}$ & Tiešāà & $\begin{array}{l}\text { Attiecina saknu biomasu } \\
\text { pret noteiktiem koka } \\
\text { parametriem }\end{array}$ & $\begin{array}{l}\text { Zaudēto un } \\
\text { norauto sakṇu } \\
\text { korekcija } \\
\end{array}$ & Lielas & Augsta \\
\hline \begin{tabular}{|l|} 
Augsnes \\
tilpumparauga \\
metode
\end{tabular} & Tiešāà & $\begin{array}{l}\text { Pieņem, ka koka saknes } \\
\text { augsnes paraugā ir } \\
\text { izvietotas vienmērīgi }\end{array}$ & $\begin{array}{l}\text { Augsnes bedrei ir } \\
\text { jābūt pietiekami } \\
\text { dziḷai }\end{array}$ & Lielas & Augsta \\
\hline $\begin{array}{l}\text { Augsnes } \\
\text { profila } \\
\text { metode }\end{array}$ & Tiešā & $\begin{array}{l}\text { Pieņem, ka pastāv } \\
\text { pozitīva korelācija starp } \\
\text { uzmērītajām saknēm } \\
\text { profilā un to kopējo } \\
\text { apjomu }\end{array}$ & $\begin{array}{l}\text { Sakņu biomasas } \\
\text { korekcija }\end{array}$ & Zemas & Zema \\
\hline $\begin{array}{l}\text { Augsnes } \\
\text { urbuma } \\
\text { metode }\end{array}$ & Tiešāà & $\begin{array}{l}\text { Kopējo saknu biomasu } \\
\text { pielīdzina sakņu } \\
\text { apjomam urbuma } \\
\text { paraugā }\end{array}$ & $\begin{array}{l}\text { Urbuma } \\
\text { diametram jābūt } \\
\text { lielākam par } 10 \mathrm{~cm}\end{array}$ & Lielas & Zema \\
\hline $\begin{array}{l}\text { Alometriskie } \\
\text { vienādojumi }\end{array}$ & Netiešā & $\begin{array}{l}\text { Sakñu apjoms ir saistīts } \\
\text { ar koka izmēriem un } \\
\text { vecumu }\end{array}$ & $\begin{array}{l}\text { Vienādojuma } \\
\text { precizitātes } \\
\text { novērtējums } \\
\text { atbilstoši } \\
\text { konkrētajiem } \\
\text { apstākḷiem } \\
\end{array}$ & Zemas & Zema \\
\hline $\begin{array}{l}\text { Virszemes un } \\
\text { sakņu masas } \\
\text { attiecíba }\end{array}$ & Netiešāā & $\begin{array}{l}\text { Pieñem, ka pastāv } \\
\text { būtiska sakarība starp } \\
\text { koka virszemes un } \\
\text { celma/sakṇu biomasu }\end{array}$ & $\begin{array}{l}\text { Attiecības } \\
\text { koriḡěšana pēc } \\
\text { vecuma vai } \\
\text { augšanas } \\
\text { apstākliem } \\
\end{array}$ & Zemas & Zema \\
\hline $\begin{array}{l}\text { Augsnes } \\
\text { skenēšana ar } \\
\text { radaru }\end{array}$ & Netiešā & $\begin{array}{l}\text { Izmantojot attālās } \\
\text { izpētes metodes }\end{array}$ & \begin{tabular}{|l|} 
Drenētas smilts \\
augsnes ar zemu \\
organisko vienu un \\
dzelzs saturu
\end{tabular} & Lielas & Zema \\
\hline \multicolumn{6}{|c|}{ Uzsūcošo sakņu biomasa } \\
\hline $\begin{array}{l}\text { Augsnes } \\
\text { urbuma } \\
\text { metode }\end{array}$ & Tiešāà & $\begin{array}{l}\text { Sakņu biomasu aprēksina } \\
\text { pēc sakņu apjoma } \\
\text { urbuma paraugā }\end{array}$ & $\begin{array}{l}\text { Urbuma } \\
\text { diametram jābūt } \\
\text { lielākam par } 10 \mathrm{~cm}\end{array}$ & Lielas & Augsta \\
\hline \begin{tabular}{|l|} 
Augsnes \\
tilpumparauga \\
metode
\end{tabular} & Tiešāà & $\begin{array}{l}\text { Pieņem, ka sakṇu masa } \\
\text { paraugā ir proporcionāla } \\
\text { kopējai masai }\end{array}$ & \begin{tabular}{|l|} 
Balanss starp \\
paraugu izmēru un \\
daudzumu
\end{tabular} & Lielas & Augsta \\
\hline $\begin{array}{l}\text { Alometriskie } \\
\text { vienādojumi }\end{array}$ & Netiešā & $\begin{array}{l}\text { Sakṇu apjoms ir atkarīgs } \\
\text { no koka izmēriem un } \\
\text { vecuma }\end{array}$ & $\begin{array}{l}\text { Vienādojumu } \\
\text { precizitātes } \\
\text { novērtējums }\end{array}$ & Zemas & Zema \\
\hline
\end{tabular}


Addo-Danso et al. (2016) secinājis, ka kritēriji kurus izmanto, lai identificētu uzsūcošās un rupjās saknes ne vienmēr zinātniskajā literatūrā ir vienoti, visbiežāk sakṇu iedalījums izveidots balstoties uz subjektīvi noteiktām diametra klasēm. Uzsūcošās saknes atšķirīgos literatūras avotos definētas kā saknes ar diametru mazāku par $0.5 \mathrm{~mm}, 1 \mathrm{~mm}, 2 \mathrm{~mm}$ vai $5 \mathrm{~mm}$. Arī rupjo sakņu minimālais caurmērs var variēt no $2-50 \mathrm{~mm}$. Tomēr lielākajā daļa pētījumu uzsūcošās saknes definētas kā saknes ar diametru $\leq 2 \mathrm{~mm}$, pārējās saknes klasificētas $k \bar{a}$ rupjās saknes. Analizējot biomasas novērtěšanas metodes (1.1. tabula), secināms, ka visa koka sakņu izrakšana ir precīzākā, tomēr arī darbietilpīgākā un dārgākā metode celma/sakṇu apjoma novērtēšanai, bet tā ne vienmēr ir piemērojama, jo ne visās augsnēs to iespējams veiksmīgi izpildīt. Augsnes tilpumparauga metode savukārt varētu būt kompromiss starp izmaksām un precizitāti. Analizējot dažādu Eiropas valstu nacionālos SEG inventarizācijas ziņojumus, secināms, ka alometriskie vienādojumi un virszemes un sakņu masas attiecību raksturojoši koeficienti ir visbiežāk izmantotās metodes celmu/sakņu biomasas novērtēšanā. Jāatzīst, ka ne vienmēr minēto metožu precizitāte ir pārbaudīta apstākḷıs, kuros tās tiek pielietotas.

\subsubsection{Alometrisko sakarību izmantošanas iespējas}

Biomasas aprēķinos alometriskās sakarības starp koku raksturojošajiem parametriem visbiežāk tiek aprakstītas ar zemāk esošo pakāpes funkciju $Y=a \mathrm{X}^{\mathrm{b}}(1.1)$ vai tās linearizēto izteiksmi $\quad \lg Y=\lg \mathrm{a}+\mathrm{b} \lg \mathrm{X} \quad$ (1.2) (Picard et al., 2015; Zianis \& Mencuccini, 2004).

$$
\begin{gathered}
Y=a X^{b} \\
\text { vai } \\
\lg Y=\lg a+b \lg X
\end{gathered}
$$

kur:

Y - aprēķināmā vērtība;

$\mathrm{X}$ - faktoriālā pazìme;

$a, b$ - regresijas koeficienti.

Alometriskie vienādojumi tiek pielietoti, lai, izmantojot viegli izmērāmas pazīmes, aprēķinātu grūtāk izmērāmas pazīmes, kā, piemēram, - koka biomasu. Mežsaimniecībā šim mērķim visbiežāk pielietotā pazīme ir koka krūšaugstuma caurmērs (D). Koka biomasa ir atkarīga ne vien no $\mathrm{D}$, bet arī koka augstuma $(\mathrm{H})$, koksnes blīvuma un vairākiem citām faktoriem, tāpēc vienādojumos bieži ietver vairākas faktoriālās pazīmes, kas l̦auj uzlabot prognozēšanas precizitāti (Chave et al., 2005; Zianis et al., 2005). Valsts mēroga biomasas aplēsēm, pielietotajos vienādojumos visbiežāk kā faktoriālās pazīmes izmanto audžu parametrus, kuri iegūti meža resursu monitoringos.

Salīdzinājumā ar D, H izmērīšana ir laikietilpīgāka un mazāk precīza, tāpēc raksturojot biomasu noteiktā platībā vai parauglaukumā, parasti visiem kokiem tiek mērīts $\mathrm{D}$, bet $\mathrm{H}$ tikai atsevišķiem kokiem (Feldpausch et al., 2011; Peng, Zhang, \& Liu, 2001). Iepriekšminētajā gadījumā vispirms tiek sastādīts augstuma-diametra vienādojums, ar kuru aprēķina izlīdzinātos augstumus visiem kokiem kuriem mērìts D un tikai tad pielieto alometriskos biomasas vienādojumus. 
Kvalitatīvi izveidoti un lokāli izstrādāti biomasas alometriskie vienādojumi ir galvenais nosacījums, lai būtu iespējams veikt korektus oglekļa uzkrājuma aprēķinus valsts mērogā (Chave et al., 2014; Temesgen et al., 2015; Weiskittel et al., 2015). Alometrisko vienādojumu pielietošana tiek uzskatīta par precīzāku metodi nekā biomasas pārrēķina koeficientu (BEF) (Petersson et al., 2012) vai plašu teritoriju raksturojošu biomasas vienādojumu izmantošana (Cifuentes-Jara et al., 2015). Ir konstatēts, ka šādu vienādojumu piemērošana konkrētas mežaudzes līmenī var radīt sistemātiskas kḷūdas līdz pat 400\% robežās (Alvarez et al., 2012; Ngomanda et al., 2014).

Biomasas vienādojumus var izstrādāt gan atsevišķu koku, gan visas kokaudzes līmen̄̄ (Somogyi et al., 2007). Atsevišķu koku biomasas vienādojumus sastāda, ietverot viegli uzmērāmas pazīmes (kā $\mathrm{D}$ un $\mathrm{H}$ ). Savukārt kokaudzes līmeņa vienādojumos biomasu aprēķina parasti no kokaudzes krājas platības vienībā (Brown \& Lugo, 1984; Cosmo, Gasparini, \& Tabacchi, 2016). Kokaudzes līmeņa vienādojumi parasti ir ļoti vienkārši un praktiski pielietojami, jo koksnes krāja ir viens no visbiežāk novērtētajiem kokaudzes raksturojošajiem rādītājiem. Pan et al. (2004) minēto metodi ir uzlabojis kokaudzes krāju iedalot klasēs, ņemot vēra augšanas apstākḷus un vecumgrupas.

Globāli aktualizējoties nepieciešamībai novērtēt oglekḷa piesaisti meža ekosistēmās, strauji pieaug izstrādāto biomasas alometrisko vienādojumu skaits visā pasaulē. Orientēties plašajā vienādojumu klāstā nereti ir ļoti grūti un radās nepieciešamība apzināt un apkopot visus jau izstrādātos biomasas aprēķina vienādojumus. GlobAllomeTree tīmekḷa vietne (http://www.globallometree.org) ir pirmā datubāze, kas izstrādāta 2013. gadā un radīta ar mērksi apkopot izstrādātos koku alometriskos vienādojumus visā pasaulē (Henry et al., 2013). Uz 2018. gada sākumu datubāzē reǵistrēti vairāk nekā 9200 dažādās valstīs publicēti dažādām koku sugām un frakcijām veidoti biomasas alometriskie vienādojumi (1.5. attēls). Šajā datu bāzē nav reǵistrēts neviens Baltijas valstīs (Latvijā, Lietuvā un Igaunijā) izveidots biomasas vienādojums.

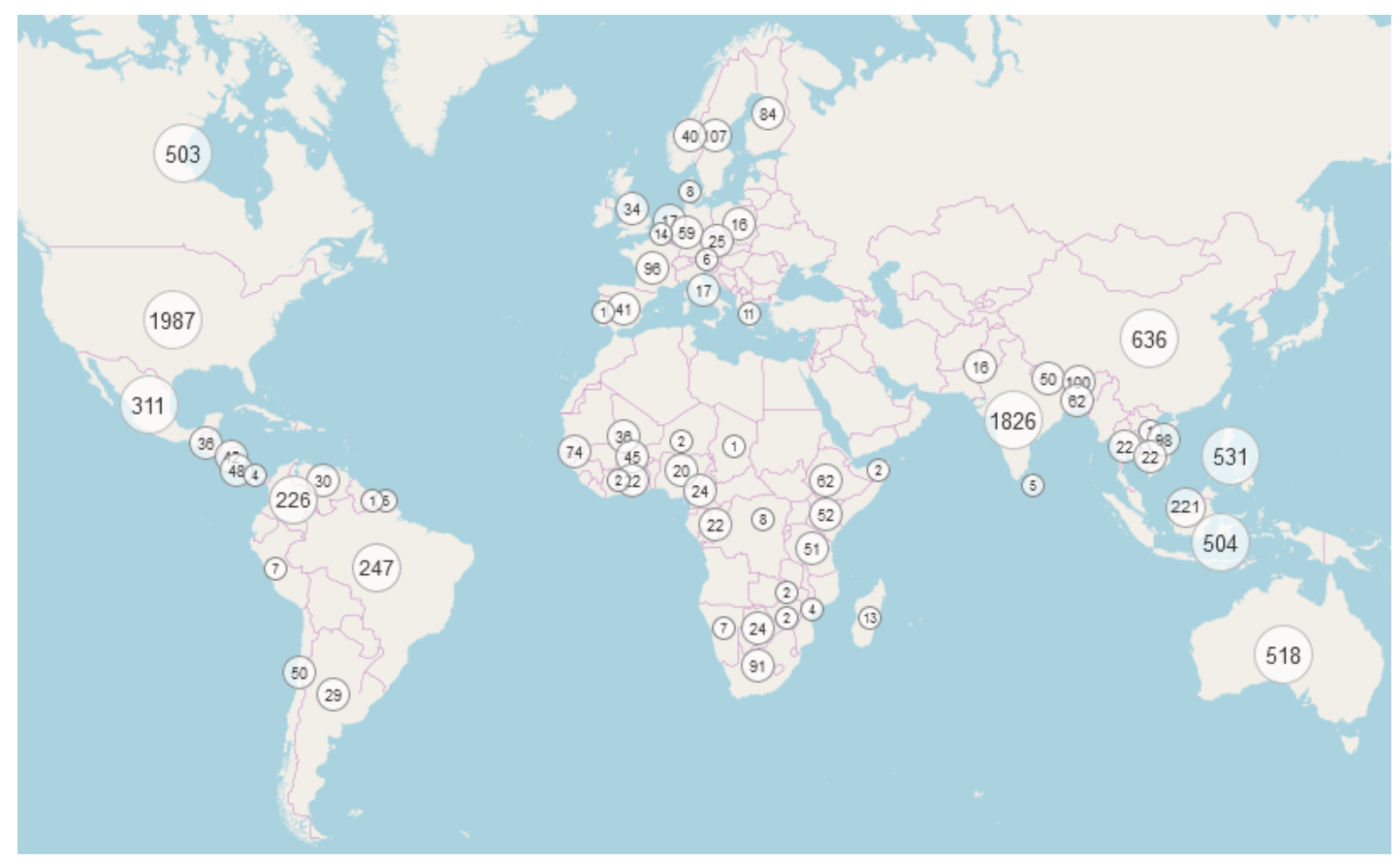

1.5. att. GlobAllomeTree datubāzē ievietotie biomasas alometriskie vienādojumi

(http://www.globallometree.org) 
Nepieciešams atzīmēt, ka daudzi no vietnē GlobAllomeTree publicētajiem vienādojumiem neatbilst IPCC (2003) "labas prakses" vadlīnijām attiecībā uz vienādojumu validāciju, matemātisko apstrādi, rezultātu atkārtojamību, ko nodrošina laba procesa dokumentācija (Cifuentes-Jara et al., 2015), līdz ar to šādu vienādojumu izmantošana nacionālajos SEG inventarizācijas ziņojumos nebūtu pieļaujama. Lai gan vairākos zinātniskos avotos ir minētas vispārīgas vadlīnijas alometrisko vienādojumu aprakstīšanai un novērtēšanai (Baldasso, Birigazzi, \& Henry, 2012; Eggleston et al., 2006; IPCC, 2003; Jenkins et al., 2004; Picard, Saint André, \& Henry, 2012; Pretzsch et al., 2002; Sileshi, 2014), tomēr nevienā dokumentā nav praktisku ieteikumu par obligāti nepieciešamo un vēlamo informāciju, kas būtu jāsniedz publicējot alometriskos vienādojumus. Šì iemesla dēl ekspertu komanda no visas pasaules (Cifuentes-Jara et al., 2015) ir izstrādājusi praktiskas rekomendācijas pēc kurām vadīties, izstrādājot alometriskos vienādojumus visā pasaulē.

\subsubsection{Tālizpētes metodes}

Kokaudžu biomasas novērtēšanai ar tālizpētes tehnoloǵijām pēdējo trīsdesmit gadu laikā ir veltīta pastiprināta uzmanība un ir izdarīts apjomīgs darbs, attīstot un pilnveidojot vairākas metodes (Sharma \& Chaudhry, 2015). Sākotnēji tālizpēte bija kā alternatīva tradicionālām biomasas novērtēšanas metodēm, turpretī šobrīd tā ir kḷuvusi par vadošo metodi plaša mēroga mežaudžu biomasas un oglekḷa krājumu novērtēšanā (Lei \& Shirong, 2017; Thurner et al., 2014). Tālizpētes galvenā priekšrocība ir îsā laikā un ar salīdzinoši zemām izmaksām iegūstama kokaudžu biomasas informācija par plašām teritorijām, arī par grūti pieejamām platībām. Paralēli biomasas novērtēšanai, tālizpētes tehnologijas izmantojamas arī, piemēram, meža tipu kartēšanai vai kokaudžu parametru noteikšanai (Toan et al., 1992; McRoberts, Liknes, \& Domke, 2014).

Nepieciešamā informācija kokaudžu biomasas novērtēšanai ar tālizpētes metodēm tiek iegūta, izmantojot pasīvos un aktīvos sensorus. Pasīvie sensori uztver virsmas atstaroto vai izstaroto elektromagnētisko starojumu. Pie pasīvajiem sensoriem pieder optiskie tālizpētes sensori, no kuriem iegūst satelītattēlus, kā arī uz lidaparātiem stiprināmas kameras aerofoto attēlu uzṇemšanai. Turpretī aktīvie tālizpētes sensori, kā piemēram, sintezētās apertūras radari (SAR) vai lāzeru staru impulsu kā aerolāzerskenēšanas radari (LIDAR) izstaro elektromagnētisko starojumu kas parasti ir mikrovilı̧nu.

Biomasas novērtēšana izmantojot pasīvos optiskos tāldarbības sensorus (IKONOS, Quickbird, Landsat TM un ETM+, SPOT 5, ASTER, NOAA AVHRR un MODIS) ir ar main̄̄gu precizitāti, kas atkarīga no sensora telpiskās un spektrālās izšķirtspējas un meža tipa (Sarker, 2010). Vairākos pētījumos, kuros izmantotas no IKONOS un Quickbird sensoriem iegūtas augstas izšķirtspējas satelītainas, ir iegūti daudzsološi rezultāti (Hyde et al., 2006; Thenkabail et al., 2004). Tomēr, izmantojot iepriekšminētos augtas izšķirtspējas attēlus, ir jārēķinās ar neprecizitātēm, kuras izraisa koku vainagu ēnas un topogrāfijas lielā spektrālā variācija. Īsviḷnu infrasarkanās joslas diapazons, ko izmanto iepriekšminētie pasīvie sensori, nav tik plašs, lai atsevišksos apstākḷlos analizētu visas spektrālās izmaiņas attēlā kas tieši ietekmē tālizpētes metodes precizitāti (Lu, 2006). Līdzīga situācija ir ar zemākas izšķirtspējas satelītainām, kuras nedod pietiekoši detalizētu informāciju par biomasas izmaiņām mazākā platības vienībā, kā rezultātā metode šobrīd izmantojama tikai plaša mēroga un aptuvenām biomasas aplēsēm.

Biomasas novērtēšanai izmanto ne tikai satelītattēlus, bet arī pārlidojumos iegūtus augstas izšķirtspējas telpiskus aerofoto attēlus. Šādi iespējams iegūt gan koku augstumu, gan diametru un vainagu mērījumus (Sharma \& Chaudhry, 2015). Lai novērtētu mežaudzes biomasu ar augstu precizitāti, ar aerofoto metodi iegūtos koku mērījumus salīdzina ar lauka mērījumu datiem un izveido model̦us biomasas aprēķināšanai. Ir apstiprināts, ka ar minēto metodi var arī samazināt meža inventarizācijas izmaksas, jo īpaši grūti pieejamās vietās un 
mežaudzēs ar lielu koku skaitu (Sharma \& Chaudhry, 2015). Pretēji satelìtattēlu analīzes iespējām, aerofoto attēlu iegūšana ir ievērojami dārgāka, tāpēc metode piemērojama samērā nelielām platībām.

Pasīvo tālizpētes tehnoloğiju izmantošanas trūkums ir arī to nespēja iegūt datus zem koku vainagiem vai caur mākoņiem, jo metode spēj analizēt tikai redzamos spektrālos datus (Le Toan et al., 1992). Jāṇem vērā, ka kopējā virszemes biomasa sastāv gan no vainaga (lapas un skujas), gan koksnes (stumbrs un zari) biomasas frakcijām. Lapu un skuju biomasa parasti sastāda līdz 10\% no visa koka biomasas (Chave et al., 2014; Dobson et al., 1992). Tāpēc optiskās un infrasarkanā starojuma atpazīšanas metodes ir efektīvākas un precīzākas lapu un skuju, nevis koksnes biomasas novērtěšanā. Spektrālie dati, kas iegūti ar iepriekšminētajām metodēm, ir atkarīgi no lapotnes ķīmiskajām un strukturālajām izmaiņām un vairāk piemēroti veǵetācijas indeksa mērǐšanai (Dong et al., 2003). Veǵetācijas indekss ir vienkāršots skaitlisks indikators, kuru pielieto zal̦ās veǵetācijas novērtēšanai un salīdzināšanai. Zinot veǵetācijas indeksa un biomasas attiecību, iespējams aprēķināt aptuvenu virszemes biomasu.

No aktīvajiem tālizpētes sensoriem, SAR izmantošana ir perspektīvs risinājums kokaudžu biomasas izpētē, jo radars līdz noteiktam dziļumam ir spējīgs nolasīt datus arī zem koku vainagiem un datu ievākšanu neietekmē meteorologiskie apstākḷi (Le Toan et al., 2011). Salīdzinājumā ar pasīvajiem tāldarbības sensoriem, kuri uztver tikai redzamo informāciju, SAR priekšrocība ir, ka tā raidītais signāls atstarojas gan no koka vainagiem un zariem, gan no zemes virsmas, l̦aujot šos datus izmantot kokaudžu biomasas aprēķiniem (Gibbs et al., 2007). Īsākos viļ̣nu garumus parasti atstaro sīkie zari un koku vainags, bet garākos - koku stumbri un resnie zari. Izmantojot SAR datus, ir grūtības atšķirt koku sugas un veǵetācijas tipus, jo radara dati atspogulo virsmu reljefu, nenosakot vai tas, piemēram, ir augsnes vai zālaugu reljefs, tādējādi atsevišş̧os gadījumos radot grūtības precīzi novērtēt biomasu (Lu et al., 2016) SAR lietošana ir piemērota homogēnām un jaunām mežaudzēm līdzenās vietās, jo metodes precizitāte samazinās, palielinoties virsmas reljefam (Le Toan et al., 2011).

Cita aktīvo sensoru sistēma ir LIDAR, kas ar lāzera stara palīdzību iegūst trīsdimensiju punktu kūli (Patenaude et al., 2004). LIDAR izmantošana ir relatīvi jauna un pašreiz visdaudzsološākā tālizpētes biomasas novērtēšanas metode, kas nodrošina tādu pat vai pat labāku precizitāti, salīdzinot ar citām iepriekš apskatītajām metodēm. LIDAR tehnologijiju plaši izmanto arī arhitektūrā un būvniecībā (Lu et al., 2016; Sharma \& Chaudhry, 2015). Ar lāzera gaismas impulsu iespējams novērtēt biomasu arī biezās mežaudzēs, kas ievērojami pārsniedz SAR iespējas (Sarker, 2010). Jaunākajos pētījumos demonstrēts, ka ar LIDAR ir iespējams iegūt mazāku biomasas aprēķinu nenoteiktību, salīdzinot ar alometriskajiem vienādojumiem (Stovall et al., 2018), tomēr šī metode raksturojama kā ļoti dārga, lai to varētu izmantot lielās platībās (Sharma \& Chaudhry, 2015). Ar LIDAR tehnoloǵijām tiek aprīkotas lidmašīnas, helikopteri vai pat droni un iegūtos trīsdimensiju punktu mākoņus apstrādā un vizualizē īpaši šim mērķim paredzētās programmās. LIDAR iegūtie dati l̦auj iegūto informāciju sadalīt slāņos, kas savukārt nodrošina to, ka iespējams atšķirt teritorijas reljefu no veǵetācijas un veikt mežaudzes parametru analīzi (Lu et al., 2016). Biomasas modelēšanai ļoti noderīga ir no LIDAR datiem iegūstamā trīsdimensionālā audzes struktūra.

Katrai no tālizpētes metodēm ir trūkumi un priekšrocības, tāpēc to apvienošana varētu būt visoptimālākais risinājums attālinātais biomasas noteikšanai (Kellndorfer et al., 2010). Optisko sensoru dati galvenokārt atspoguḷo virsmas īpašības, bet radaru dati nodrošina vertikālu datu struktūru, tāpēc abu datu sapludināšana kopā varētu sniegt jaunu informāciju par kokaudzi. Lai gan satelītattēlu un LIDAR datu apvienošana tiek vērtèta kā visdaudzsološākais risinājums liela mēroga biomasas novērtēšanai (Lu et al., 2016), tomēr atsevišķos pêtījumos šì pieeja ir apšaubīta un atspoguḷota ar mainīgām sekmēm. Vairākos pētījumos demonstrēts, ka optisko datu pievienošana ar LIDAR iegūto informāciju neuzlaboja vai vien nedaudz ietekmēja biomasas prognozēšanas precizitāti (Clark et al., 2011; Latifi, Fassnacht, \& Koch, 2012). Savukārt Anderson et al. (2008) un Laurin et al. (2014) 
konstatējuši, ka LIDAR un hiperspektrālo radaru iegūtās informācijas sapludināšana būtiski uzlaboja biomasas aplēses mērenās un tropiskās joslas mežos.

Lielākā dal̦a prognožu par biomasu un oglekḷa uzkrājumiem mežaudzēs visā pasaulē ir loti aptuvenas, tāpēc tālizpētes metožu attīstība ir vienīgais reālais risinājums kā šo biomasas aprēķinu nenoteiktību samazināt. Šajā kontekstā LIDAR izmantošana ir kḷuvusi par dzīvotspējīgāko tālizpētes metodi (Stovall et al., 2018), jo biomasas datu ievākšana pēc destruktīvās metodes, lai raksturotu liela mēroga biomasas izmaiņas, nav iespējama.

\subsection{Reducētā blīvuma nozīme biomasas un oglekḷa uzkrājumu novērtēšanā}

Koksnes blīvums ir viens no galvenajiem koksnes kvalitātes rādītājiem, jo tas netieši raksturo arī citas fizikālās, gan arī mehāniskās koksnes īpašības, kā arī nosaka koksnes izmantojamības iespējas. Piemēram, konstrukciju zāğmateriāliem nepieciešams liels koksnes blīvums un izturība, bet zema blīvuma koksne ir vairāk piemērota celulozes un papīra rūpniecībā (Saranpää, 2003). Visā pasaulē arvien lielāka uzmanība tiek pievērsta oglekḷa emisiju samazināšanai būvniecībā un produktu ražošanā. Lai samazinātu $\mathrm{CO}_{2}$ daudzumu atmosfērā un attīstoties jaunām tehnolog̣ijām, arvien vairāk tiek projektētas un būvētas augstas izturības èku konstrukcijas un ražoti produkti, kuros izmanto koksni (Cabeza et al., 2013; Gustavsson et al., 2006). Koksnes izmantošana būtībā ir $\mathrm{CO}_{2}$ neitrāls process; koki augot piesaista $\mathrm{CO}_{2}$, un tos sadedzinot vai tiem sadaloties, tieši tāds pats daudzums $\mathrm{CO}_{2}$ izdalās atpakal atmosfērā. Ilgtermiņa efekts $\mathrm{CO}_{2}$ līdzsvarošanai tiek panākts, kad koksne vispirms tiek izmantota būvniecībā vai interjerā, un pēc tam kā enerǵijas avots. Koksnes blīvums norāda uz to, cik daudz oglekḷa koksnē ir akumulēts (Chave, 2005). Oglekḷa saturs koksnē ir apmēram 50\% no tā sausas masas un, koksni izmantojot produktu ražošanā, tas tiek noglabāts šajā produktā.

Viens no svarīgākajiem faktoriem kas ietekmē koksnes brīvumu ir ūdens îpatsvars koksnē (1.6. attēls). Svaigi cirstā stāvoklī koksne ir smagāka, bet to žāvējot tā pakāpeniski zaudē ūdeni un kḷūst vieglāka. Tā kā blīvums ir masas attiecība pret tilpumu, atspogulojot koksnes blīvuma datus svarīgi ir norādīt, pie kāda koksnes mitruma tas ticis mērīts, jo koksnei mitruma ietekmē ir tendence palielināt gan tilpumu, gan masu (Saranpää, 2003). Blīvuma definīcijas var atšksirties atkarībā no mērīto koksnes paraugu relatīvā mitruma. Kokrūpnieki visbiežāk nosaka svaigi cirstas koksnes blīvumu (angḷu val. green wood density) vai gaissausas koksnes blīvumu (angḷu val. air-dry wood density) ko nosaka pie standartmitruma, tomēr jāṇem vērā, ka daudzās valstīs koksnes standartmitrumu definēe atšksirīgi; koksnē atlikušais ūdens saturs var būt robežās no $12 \%$ līdz 15\% (Chave, 2005). Absolūti sausas koksnes blīvums (anglu val. oven dry wood density) tiek noteikts pie $0 \%$ relatīvā mitruma un ir plaši lietots zinātniskajā literatūrā, jo izslēdz jebkāda veida ūdens satura ietekmi uz blīvuma mērījumiem. Biomasas un oglekḷa uzkrājumu aprēķināšanai izmanto reducēto jeb bāzes blīvumu (angḷu val. basic density), kas raksturo sausas koksnes masu piebriedušas koksnes tilpuma vienībā. 


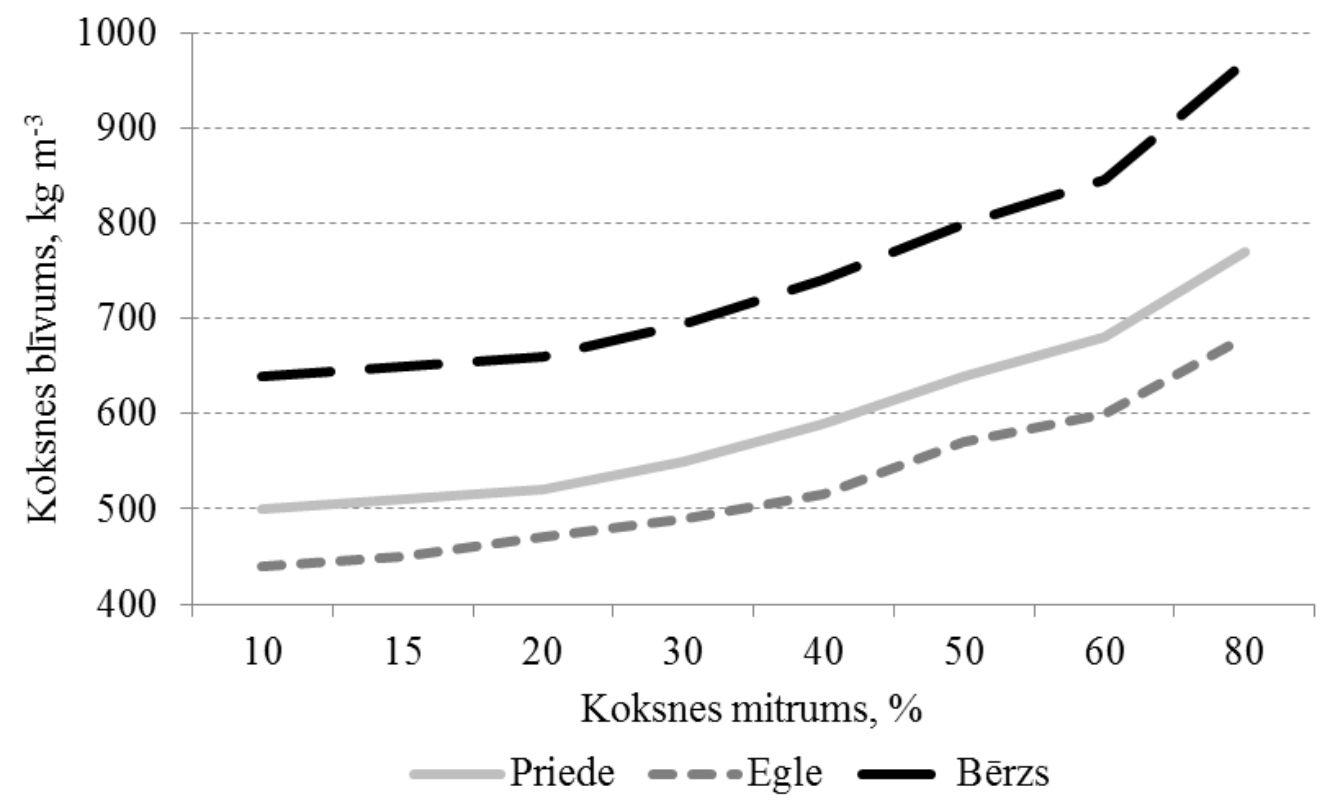

1.6. att. Koksnes blīvums atkarībā no koksnes mitruma

(Kops, 1997)

Koksnes blīvumu salīdzināšana un nepareiza interpretēšana, ignorējot to atškiirīgās nozīmes, joprojām rada pārpratumus. Tādēḷ, atspogulojot koksnes blīvuma vērtības, vienmēr jānorāda mitruma saturs, pie kāda noteikts koksnes tilpums un masa, kā arī žāvēšanas temperatūra, jo arī tai ir ietekme uz absolūti sausas koksnes masas noteikšanu (Petersson \& Stahl, 2006). Absolūti sausas masas noteikšanai, koksni žāvējot zem $100{ }^{\circ} \mathrm{C}$ temperatūras, paraugi netiek pilnībā izžāvēti, turpretī, ja žūšanas temperatūra pārsniedz $105^{\circ} \mathrm{C}$ - paraugi var apdegt (Ilic et al., 2000).

Koksnes mitrums vai blīvums ir galvenie mainīgie koksnes masas novērtēšanā (Henry et al., 2010). Aprēķinot stumbra biomasu no blīvuma datiem, ir nepieciešami precīzi stumbra tilpuma mērījumi (Bergstedt \& Olesen, 2000; Repola, 2008, 2009; Henry et al., 2010; Skovsgaard, Bald, \& Nord-Larsen, 2011). Stumbra biomasas aprēķinu ticamība lielā mērā ir atkarīga no tā, cik precīzi tiek aprēķināts stumbra tilpums un vidējais stumbra reducētais blīvums. Vidējā blīvuma aprēksināšanai zinātniskajā literatūrā tradicionāli tiek pielietotas dažādas metodes. Ir pierādîts, ka priedes, egles un bērza stumbra blīvums $25 \%$ augstumā aptuveni ir tāds pats kā vidējais blīvums visā stumbrā (Hakkila, 1979). Metodes trūkums ir tas, ka šādi nav iespējams noteikt blīvumu lieliem kokiem, jo ir apgrūtinoši augošam kokam blīvuma paraugu ievākt šādā augstumā. Tāpēc Hakkila (1979) ir izveidojis regresijas vienādojumus, aprēķinot priedes, egles un bērza vidējo stumbra blīvumu no koka vecuma, caurmēra un krūšaugstuma blīvuma datiem. Metode raksturojama kā saudzīga pret kokiem, jo piẹ̦auj koksnes paraugus iegūt ar pieauguma svārpstu. Pati vienkāršākā metode, pārrēksinot stumbra tilpumu biomasā, ir lietot konstantas blīivuma vērtības katrai koku sugai (Bartelink, 1996).

Stumbra biomasas noteikšanai pēc destruktīvās metodes ir nepieciešami precīzi blīvuma dati par katru koku, tāpēc vidējo stumbra blīvumu ir jānosaka nevis pēc viena, bet vairākiem paraugiem. Iegūtie paraugi var būt stumbra šķērsgriezuma ripas (Repola, 2008, 2009), koksnes tilpumparaugi, kas iegūti ar $12 \mathrm{~mm}$ platu pieauguma svārpstu (Chave, 2005; Liepins \& Rieksts-Riekstins, 2013), kā arī izzāgeēti dažādu dimensiju šksērsgriezuma ripu sektori (Herajarvi, 2004; Heräjärvi \& Junkkonen, 2006; Millers \& Magaznieks, 2012). Iegūstamo paraugu skaitam vajadzētu būt proporcionālam stumbra garumam, optimālajā variantā ik pa 1 vai 2 metriem (Breu et al., 2012).

Vidējo stumbra blīivumu ir grūti noteikt vairāku iemeslu dēḷ. To ietekmē daudzi faktori, piemēram, koku augšanas ġeogrāfiskais reǵions, koka augšanas apstākḷi un tā sociālais 
statuss, koka vecums un augstums, augšanas temps, kā arī dažādi genētiskie faktori (Dibdiakova \& Vadla, 2012; Hakkila, 1979; Saranpää, 2003; Singh, 1984). Piemēram, parastās egles stumbra vidējais blīvums vienas kokaudzes ietvaros mainās no 5-10\% (Skovsgaard et al., 2011). Tāpēc konstantu blīvuma vērtību izmantošana biomasas novērtēšanā var radīt ievērojamas sistemātiskas kḷūdas.

Stumbra blīvums var mainīties ne tikai starp vienas sugas kokiem, bet arī viena indivīda ietvaros. Literatūrā ir analizētas blīvuma izmaiņas gan virzienā no serdes uz mizu, gan arī no saknēm uz galotni (Heräjärvi \& Junkkonen, 2006; Jyske, Mäkinen, \& Saranpää, 2008; Repola, 2006). Izteikta blīvuma samazināšanās virzienā uz galotni ir novērojama priedei, bet mazāk izteikta bērzam (Hakkila, 1979; Repola, 2006). Savukārt, eglei un apsei blīvums stumbra garenvirzienā ir vairāk vai mazāk konstants; līdz stumbra vidusdaļai tas nedaudz samazinās, bet tad virzienā uz galotni atkal palielinās (Heräjärvi \& Junkkonen, 2006; Karki, 2001; Repola, 2006). Pretēji iepriekšminētajām koku sugām, baltalkšņa koksnes blīvums galotnes virzienā pakāpeniski palielinās (Saranpää, 2003).

Koksnes blīvuma izmaiņas stumbra garenvirzienā ir jāṇem vērā, lai izvairītos no sistemātiskām kḷūdām, nosakot vidējo stumbra blīvumu, kā arī, plānojot ievākto paraugu skaitu. Īpaši svarīgi tas ir koku sugām ar izteiktu blīvuma mainību garenvirzienā kā priedei. Piemēram, priedes, egles un bērza blīvuma vērtības $1.3 \mathrm{~m}$ augstumā ir lielākas nekā vidējās blīvuma vērtỉbas visam stumbram (Hakkila, 1979). Ja blīvums netiek noteikts visai šḳērsgriezuma ripai vienlaicīgi, tad jāņem vērā arī blīvuma radiālās izmaiņas katrā šksērsgriezuma ripā.

Radiālās blīvuma izmaiņas koka stumbrā matemātiski ir grūti aprakstīt, jo tās atšķiras katrai koku sugai atkarībā no augšanas apstākḷiem un no vietas stumbrā. Vairumam koku sugu, izņemot tās, kuru koksne ir ar izkliedētiem traukiem kā, piemēram, bērzam un papelei, pastāv cieša sakarība starp koku gadskārtu platumu un koksnes blīvumu (Saranpää, 2003). Koksnes gadskārtu agrīnā dạ̧a veidojas pavasarī un vasarā nekā vēlīnā koksnes daļa, kura veidojas vasaras otrajā pusē. Ir pieņemts uzskatīt, ka ātraudzīgāko koku koksne ar platākām koksnes gadskārtām (lielāku agrīnās koksnes īpatsvaru) ir mazāk blīva nekā lēnāk augušiem kokiem (Alteyrac et al., 2005; Gardiner et al., 2011). Vēlīnās koksnes īpatsvars koksnes gadskārtās kuras atrodas tuvu serdei parasti ir mazāks, bet virzienā uz mizu îpatsvars palielinās (Saranpää, 2003). Pieaugušām eglēm vēlīnās koksnes īpatsvars pieaug no 20\% 20 . gadskārtā līdz 35\% 110. gadskārtā (Hakkila \& Uusvaara, 1968), ietekmējot arī blīvuma izmaiņas. Egles stumbrā koksnes blīvums tāpat kā vēlīnās koksnes īpatsvars palielinās virzienā no serdes uz mizu (Hakkila, 1979). Wilhelmsson et al. (2002) atklāja, ka stumbra krūšaugstuma caurmērs, gadskārtu skaits un klimatiskie rādītāji eglei un priedei ietekmē attiecīgi 50\% un 59\% no blīvuma izmaiñām.

Blīvuma izmainas stumbra šķērsgriezuma ripās ir jāṇem vērā gadījumos, kad nav iespējams izmērīt blīvumu visai ripai vienlaicīgi, kā tas parasti ir paraugiem, iegūtiem no lieliem kokiem. Tā kā tradicionāli blīvuma parauga tilpums tiek mērīts ar iegremdēšanas metodi ūdeni (Ilic et al., 2000), tad ir laikietilpīgi un neracionāli izmantot liela izmēra paraugus. Praksē visbiežāk stumbra šķērsgriezuma ripas, ievērojot noteiktas shēmas sadala mazāka izmēra blīvuma paraugos, lai tie ietilptu mērtraukā (Herajarvi, 2004; Heräjärvi \& Junkkonen, 2006; Karki, 2001; Millers \& Magaznieks, 2012). Shēmu ievērošana, sagatavojot paraugus, ir priekšnosacījums, lai pēc tam varētu aprēķināt vidējo svērto blīvumu visai šķērsgriezuma ripai un tālāk jau visam koka stumbram.

SEG nacionālo inventarizācijas ziṇojumu sastādīšanas vadlīniju (Eggleston et al., 2006) aprakstītā biomasas aprēķina metodika piedāvā vidējās reducētā blīvuma vērtības (1.2. tabula) kuras pielietojamas, ja nav zinātniski pamatotu blīvuma datu par raksturīgākajām koku sugām. Diemžēl vadlīniju piedāvātās, tāpat kā citviet literatūrā lietotās blīvuma vērtības stumbra biomasas aprēķinos ir definētas kā koksnes nevis visa stumbra vidējās blīvuma vērtības. 
Reducētā blīvuma vērtības Latvijai raksturīgām koku sugām (Eggleston et al., 2006)

\begin{tabular}{cc}
\hline Koku suga & Blīvums kg m${ }^{-3}$ \\
\hline Priede & 420 \\
Egle & 400 \\
Bērzs & 510 \\
Apse & 350 \\
Baltalksnis & 450 \\
Melnalksnis & 450 \\
Osis & 570 \\
Kḷava & 520 \\
Liepa & 430 \\
Ozols & 580 \\
\hline
\end{tabular}

Somijā veiktajos pētîjumos ir pierādīts, ka mizas blīvums priedei ir relatīvi mazāks, bērzam tas ir nedaudz lielāks, bet eglei praktiski identisks vidējam koksnes blīvumam (Hakkila, 1979). Arī citām koku sugām, tajā skaitā apsei ir novērotas lielas (līizz $136 \mathrm{~kg} \mathrm{~m}^{-3}$ ) reducētā blīvuma atšksirības starp stumbra koksni un mizu (Erickson, 1972). Tā kā mizas masas īpatsvars koka stumbrā ir robežās no 9.5-16.3\% skujkokiem un 10.6-24.1\% lapkokiem (Uusvaara \& Pekkala, 1979), tad vidējā koksnes blīvuma piemērošana stumbra biomasas aprēķinos rada sistemātiskas kḷūdas. Analizējot zinātniskajā literatūrā pieejamo informāciju, secināms, ka vidējās stumbra reducētā blīvuma vērtības, kurās ņemts vērā arī mizas îpatsvars un blīvums, vairumam koku sugu nemaz nav pieejamas, tāpēc aprēķinos tiek izmantotas koksnes blīvuma vērtības.

Alternatīva metode stumbra biomasas noteikšanai, neizmantojot blīvumu, ir aprēķināt svaigi cirsta stumbra masas attiecību pret absolūti sausu tā masu, jeb citiem vārdiem sakot, noteikt ūdens daudzumu koka stumbrā (Afif-Khouri, 2013; Ebuy et al., 2011; Elfving, Ulvcrona, \& Egnell, 2017; Marklund, 1988; Mugasha et al., 2013; Smith et al., 2014). Metodi visbiežāk pielieto gadījumos, kad ir neliels paraugkoku skaits, kā arī zaru un sakņu biomasas aprēķināšanai, jo šīm koka frakcijām, pretēji stumbram, ir ļoti darbietilpīgi noteikt tilpumu. Izstrādājot Zviedrijas nacionālos biomasas vienādojumus, Marklund (1987) aprakstījis ieteikumus, kuri jāṇem vērā, lai neveidotos sistemātiskas kḷūdas, pielietojot iepriekšminēto metodi. Pirmkārt, koksnes mitruma paraugi ir pēc iespējas ātrāk jānosver vai jāsapako uzglabāšanai, īpaši vējainās, siltās, nokrišņiem bagātās dienās, kad tie ļoti strauji iztvaiko vai uzņem ūdeni. Otrkārt, ja paraugus nav iespējams uzreiz nosvērt, tie obligāti jāuzglabā telpā ar zemu temperatūru, lai uzglabāšanas procesā koksne nezaudē daļu oglekļa, ietekmējot absolūti sausas masas mērījumus. Marklund (1987) arī secinājis, ka pie liela paraugkoku skaita un pie lieliem paraugu transportēšanas attālumiem, precīzi ievērot abus iepriekšminētos nosacījumus ir praktiski neiespējami.

\subsection{Oglekḷa novērtēšanas metožu salīdzinājums Eiropas mežos}

Klimata pārmaiņu kontekstā, mežaudžu spēja piesaistīt atmosfērā esošo oglekli un ražot atjaunojamos energoresursus (biomasu) ir kḷuvusi par vienu no nozīmīgākajiem vadmotīviem, plānojot dabas resursu apsaimniekošanas stratēǵijas visā Eiropā. Vidēji visās Eiropas Savienības dalībvalstīs $16.7 \%$ no patērētās enerğijas tiek iegūta no atjaunojamajiem resursiem, no kuriem lielāko īpatsvaru - 64.4\% sastāda biomasa (EUROSTAT, 2017). Pieaugošă interese par Eiropas mežu pareizu apsaimniekošanu klimata pārmaiņu mazināšanas kontekstā, pamato nepieciešamību nepārtraukti aktualizēt informāciju par mežaudžu stāvokli un to augšanas gaitu. Informāciju par Eiropas meža platības izmaiņām, meža koksnes resursu 
struktūru un dinamiku, mežaudžu bojājumiem, atmirušo koksni un uzkrātu hronoloǵisku informāciju par mežaudžu augšanas gaitu pamatā veido nacionālie MRM, kuru datu vākšanas metodikas var atšķirties atkarībā no valstu konceptuālās pieejas (Tomppo et al., 2010). Neskatoties uz atšķirīibām datu ievākšanas metodikās, Eiropā tieši MRM dati visbiežāk lietoti, sastādot nacionālos ziṇojumus UNFCCC vajadzībām par ZIZIMM sektoru (Tomppo et al., 2010).

MRM pamatā uzkrāj koku mērījumu datus un tos izmanto, lai iegūtu precīzu informāciju par meža resursiem valsts un starptautisko statistikas pārskatu vajadzībām. Tā kā kokaudžu biomasa ir aprēķināma no krājas vai koku caurmēra, augstuma mērījumiem, un ogleklis veido apmēram pusi no š̄is masas, tad tie paši MRM koku mērījumu dati ir izmantojami, lai novērtētu kokaudzēs piesaistītā oglekḷa apjomus. Tā kā mežu platības Eiropā nav viendabīgas, aptverot dažādas koku sugas un to augšanas apstākḷus, katra konvenciju parakstījusī dalībvalsts oglekḷa uzkrājumus savos mežos novērtē pēc individuālas aprēķina metodikas (Neumann et al., 2016). Novērtējot oglekḷa piesaistes potenciālu Eiropas mežos, aprēķina metožu atšķkirību dēl ir grūti apzināt kopējo aprēķinu nenoteiktību.

Analizējot UNFCCC un Kioto protokolu parakstījušo dalībvalstu nacionālos SEG inventarizācijas ziṇojumus (UNFCCC, 2018) secināms, ka pielietotās dalībvalstu kokaudžu biomasas aprēķināšanas metodes ir diezgan atškirīgas. Daudzas konvenciju parakstījušās dalībvalstis, no Baltijas valstīm tajā skaitā arī Igaunija, kokaudžu biomasu aprēķina izmantojot SEG nacionālo inventarizācijas ziņojumu sastādīšanas vadlīniju (Eggleston et al., 2006) ieteiktos BEF vai koksnes blīvuma vērtības. Turpretī Lietuva kombinē vadlīniju ieteiktos pārrēķina koeficientus ar Krievijā izstrādātajiem un paredzētiem Eirāzijas ziemeļu daļai. Gan Lietuva, gan Igaunija kokaudžu biomasu pārrēķina no MRM aprēksinātajiem kokaudžu krājas datiem.

Salīdzinot citu Eiropas valstu biomasas aprēķina metodes (1.3. tabula) secināms, ka individuālu koku krūšaugstuma caurmēra un koku augstumu datu izmantošana ir tikpat izplatīta prakse aprēķinot biomasu kā izmantot informāciju par kokaudžu krāju.

1.3. tabula

Kokaudžu biomasas aprēḳina metožu salīdzinājums dažādās Eiropas valstīs

\begin{tabular}{|c|c|c|c|}
\hline Reǵions & Valsts & Metode* & Ievades parametri* \\
\hline \multirow{3}{*}{ Ziemel̦eiropa } & Somija & $\mathrm{AV}$ & $\mathrm{D}, \mathrm{H},(\mathrm{CR})$ \\
\hline & Norvēgiija & $\mathrm{AV}$ & $\mathrm{D},(\mathrm{H})$ \\
\hline & Zviedrija & $\mathrm{AV}$ & $\mathrm{D},(\mathrm{H})$ \\
\hline \multirow{5}{*}{ Centrālā-Rietumeiropa } & Austrija & $\mathrm{AV}+\mathrm{BEF}$ & $\mathrm{D},(\mathrm{H}, \mathrm{CR}, \mathrm{A})$ \\
\hline & Bel̦gija & $\mathrm{AV}+\mathrm{BEF}$ & $\mathrm{D},(\mathrm{H})$ \\
\hline & Francija & $\mathrm{BEF}$ & $\mathrm{D},(\mathrm{H})$ \\
\hline & Vācija & AV & $\mathrm{D},(\mathrm{H})$ \\
\hline & Nīderlande & $\mathrm{AV}+\mathrm{BEF}$ & $\mathrm{D},(\mathrm{H})$ \\
\hline \multirow{3}{*}{ Centrālā-Austrumeiropa } & Čehija & $\mathrm{AV}+\mathrm{BEF}$ & $\mathrm{D},(\mathrm{H}, \mathrm{A})$ \\
\hline & Polija & $\mathrm{BEF}$ & M \\
\hline & Rumānija & BEF & M \\
\hline \multirow{2}{*}{ Dienvideiropa } & Itālija & $\mathrm{BEF}$ & $\mathrm{M}$ \\
\hline & Spānija & $\mathrm{BEF}$ & M \\
\hline
\end{tabular}

*AV - alometriskie vienādojumi, BEF - biomasas pārrēķina koeficienti, D - krūšaugstuma caurmērs, $\mathrm{H}$ - augstums, CR - vainaga parametri, V - tilpums, A - vecums, M - krāja. Vērtības iekavās norāda, ka parametri lietoti ne visām biomasas frakcijām. 
Trīs no apskatītajām Eiropas valstīm (Somija, Austrija, Čehija) savos SEG inventarizācijas ziņojumos, papildus koka $\mathrm{D}$ un $\mathrm{H}$, lieto arī citas kokus raksturojošas vērtības, kā piemēram - dažādus vainaga parametrus, stumbra tilpumu un koka vecumu. No apskatītajām biomasas aprēķina metodēm (1.3. tabula) četrās valstīs (Somija, Norvēgija, Zviedrija un Vācija) tiek lietoti alometriskie vienādojumi, piecas valstis (Francija, Polija, Rumānija, Itālija un Spānija) izmanto nacionālas BEF vērtības, bet atsevišķām koku sugām vai frakcijām trūkstošās BEF vērtības lielākoties tiek aizgūtas no vadlīnijām vai kaimiņvalstīm. Četru valstu (Austrija, Beḷgija, Nīderlande, Čehija) kokaudžu biomasas aprēķina metodes izmanto kombināciju starp BEF un alometriskajiem vienādojumiem dažādu koka frakciju (stumbrs, zari, saknes) biomasas aprēķiniem.

Somijā nacionālajiem alometriskajiem biomasas vienādojumiem (Repola, 2008, 2009) kā mainīgās vērtības pamatā lieto $\mathrm{D}$ un $\mathrm{H}$, bet skuju, lapu un zaru biomasas aprēķināšanai papildus lietoti arī dažādi vainaga parametri. Norvēgijas mežu oglekḷa uzkrājumu aprēķina metodika izmanto Zviedrijā izstrādātos alometriskos biomasas vienādojumus (Marklund, 1988; Petersson \& Stahl, 2006). Līdz ar to abu valstu metodikās, aprēķinot virszemes (stumbrs, zari, skujas, lapas) biomasu, lieto H un D. Turpretī sakṇu biomasa tiek aprēķināta tikai no koku D mērījumiem.

Piecas no apskatītajām valstīm (1.3. tabula) - Austrija, Beḷgija, Francija, Vācija un Nīderlande pēc Pārtikas un lauksaimniecības organizācijas (FAO) klasifikācijas (FAO, 2011) pieder Centrāl-Rietumeiropai. Austrijas biomasas aprēķinu metodika izmanto gan BEF, gan alometriskos biomasas vienādojumus, atkarībā no tā, kurai koka frakcijai aprēķini tiek veikti. Zaru, skuju un sakņu biomasas aprēķināšanai tiek izmantoti alometriskie biomasas vienādojumi (Ledermann \& Neumann, 2006), kuriem main̄̄gās vērtības ir D un vainaga parametri, bet sakṇu biomasas vienādojumiem arī koka vecums (Offenthaler \& Hochbichler, 2006). Stumbra biomasa tiek aprēksināta pēc īpaši Austrijai izstrādātiem pārrēķina koeficientiem, kuros tiek ņemts vērā stumbra tilpums, koksnes blīvums un stumbra forma. Kokaudžu biomasas aprēķinu metodika Beḷgijā vispirms izmanto alometriskos vienādojumus, lai aprēķinātu stumbru tilpumus. Tilpums tiek reizināts ar vidējām reducētā blīvuma vērtībām katrai koku sugai, iegūstot stumbra biomasu. Lai aprēķinātu kopējo koka biomasu no stumbra datiem, tiek lietoti FAO rekomendētie BEF. Līdzīgi kā Beḷgijā pielietotajā metodikā, arī Francijas metodika, vispirms paredz aprēķināt koka tilpumu, bet, atšksirībā no Beļgíjas, tilpums tiek aprēķināts ne tikai stumbram, bet visai koku virszemes daļai pēc speciālām formulām (Vallet et al., 2006). Pēc tam koka tilpums tiek pārrēķināts biomasā, izmantojot Francijai izstrādātas BEF un blīvuma vērtības. Vācijā kokaudžu biomasu novērtē tikai ar alometriskajiem biomasas vienādojumiem. Dažādi virszemes biomasas vienādojumi tiek piemēroti atkarībā no koku vidējā D (koki, kuru D lielāks par $10 \mathrm{~cm}$; koki ar D mazāku par $10 \mathrm{~cm}$; koki, kuri nav sasnieguši $1.3 \mathrm{~m}$ augstumu) un tā katrai koku sugai, kā mainīgās vērtības izmantojot $\mathrm{D}, \mathrm{H}$ vai abus šos parametrus. Sakṇu biomasas vienādojumos kā mainīgo vērtību izmanto tikai D un, atsevišşāam koku sugām, vienādojumi ir aizgūti no Francijas un Zviedrijas. Nīderlandē visām koku sugām biomasu aprēķina piemērojot BEF. Savukārt valsti raksturojošās BEF vērtības ir aprēḳinātas pēc biomasas alometriskajiem vienādojumiem (Nabuurs et al., 2005), kuri izplatîtākajām koku sugām izstrādāti Krievijā, bet atsevišksām koku sugām arī Zviedrijāa, Francijā, Austrijā un arī pašā Nīderlandē.

Trīs no apskatītajām valstīm (1.3. tabula), Čehija, Polija un Rumānija pēc FAO klasifikācijas (FAO, 2011) pieder Centrāl-Austrumeiropas valstu grupai. Čehijas biomasas aprēķinu metodika ir līdzīga Nīderlandes metodikai. Vispirms pēc nacionālajiem vai Eiropas vispārīgajiem biomasas vienādojumiem dažādām koku frakcijām tiek aprēḳinātas no valdošās koku sugas un vecumgrupas atkarīgas BEF vērtības (Lehtonen et al., 2004), kuras pielieto biomasas aprēķināšanai no krājas, kas aprēķināta pēc stumbra tilpuma vienādojumiem. Polija, tāpat kā Rumānija, virszemes un sakṇu biomasas aprēķinos lieto IPCC vadlīniju ieteikto metodi un BEF vērtības. Aprēķiniem nepieciešamās koku sugu vidējās blīvuma vērtības 
tomēr ir balstîtas uz Polijā un attiecīgi Rumānijā ievāktiem datiem. Atšķirībā no Rumānijas, kurā izmanto nacionālās blīvuma vērtības, Polijā reducētā blīvuma aprēķinu pamatā ir gaissausas koksnes blīivuma (pie 15\% relatīvā mitruma) un koksnes rukuma reizinājums.

Itālija un Spānija 2017. gada SEG inventarizācijas ziņojumā oglekḷa apjoma novērtēšanai mežaudzēs izmanto BEF vērtības. Itālija lieto nacionālās BEF vērtības un koksnes blīvumu datus gan koku virszemes, gan sakṇu biomasas aprēḳināšanai (Federici et al., 2008). Spānija izmanto nacionālās BEF vērtības tikai kokaudžu virszemes biomasas aprēķināšanai, bet informāciju par sakṇu BEF un blīvuma vērtībām iegūst no IPCC vadlīnijām (Eggleston et al., 2006). Turpmākajos ziņojumos Spānija plāno izmantot Spānijā izstrādātus alometriskos biomasas vienādojumus izplatîtākajām koku sugām un aprēķināt biomasu bez pārrēķinu koeficientiem (Neumann et al., 2016).

Zviedrijā veiktajā pētījumā ir pierādīts, ka konstantu BEF vērtību pielietošana biomasas aprēķinos var radīt ievērojamu kḷūdu (Petersson et al., 2012), jo BEF vērtības mainās atkarībā no audzes vecuma, sastāva, struktūras, augšanas apstākḷiem un krājas (Lehtonen et al., 2004; Wirth et al., 2004; Magalhães \& Seifert, 2015). Zviedru pētījums apstiprināja, ka vislielāko precizitāti biomasas novērtēšanā iespējams sasniegt, izmantojot katrai koku sugai izstrādātus biomasas alometriskos vienādojumus, kuri tiek piemēroti koku individuālajā līmenī. Tām valstīm, kurām nav izstrādātu reprezentatīvu biomasas alometrisko vienādojumu, piemērotākais risinājums varētu būt vecuma atkarīgas BEF vērtības (Lehtonen et al., 2004; Petersson et al., 2012).

Mūsdienās BEF vērtības joprojām tiek bieži izmantotas dažādu valstu nacionālajos SEG inventarizācijas ziņojumos, jo nacionālie MRM sniedz informāciju par stumbra tilpumiem nevis biomasu koka saknēs, zaros, skujās, lapās un stumbrā, balstoties uz atsevišḳu koku alometriskajiem biomasas vienādojumiem. Tomēr vien daži pētījumi ir novērtējuši iespējamās kḷūdas lielumu, kas varētu rasties, lietojot nepiemērotas BEF vērtības (Albaugh et al., 2009; Lehtonen et al., 2007). Biomasas tieša aprēķināšana no koku uzmērījumu datiem nacionālajos SEG inventarizācijas ziņojumos ir salīdzinoši jauna tendence un joprojām nav plaši lietota reprezentatīvu biomasas vienādojumu trūkuma dẹl (Cosmo et al., 2016). Kā pagaidu risinājums minētajai situācijai varētu būt vispārīgie biomasas vienādojumi, kuri ir pieejami daudzām koku sugām un ğeogrāfiskajiem reǵioniem (Chojnacky, Heath, \& Jenkins, 2014; Forrester et al., 2017; Muukkonen, 2007; Wirth et al., 2004).

Tāpat kā biomasas aprēķinu metodes, arī oglekļa saturs koksnes sausnā katrai valstij nacionālajos SEG inventarizācijas ziņojumos (UNFCCC, 2018) ir definēts atšķiirīgi. Vadlīniju (Eggleston et al., 2006) piedāvātās vidējās oglekļa satura īpatsvara noklusētās vērtības boreālās un mērenās joslas mežiem 48\% - lapkokiem, 51\% - skujkokiem vai 47\% - visiem kokiem, tiek lietotas vairākās valstīs, tostarp Lietuvā un Igaunijā. Igaunijā lieto visu koku sugu vidējo oglekḷa satura vērtību, bet Lietuva skujkokiem un lapkokiem lieto atsevišksas vērtības. Salīdzinot citu Eiropas valstu lietotās oglekḷa īpatsvara vērtības secināms, ka tās visos gadījumos ir robežās no $47-51 \%$ (1.4. tabula).

1.4. tabula

\section{Dažādās Eiropas valstīs lietotais oglekḷa saturs biomasā}

\begin{tabular}{ccc}
\hline Valsts & Skujkoki & Lapkoki \\
\hline Somija & $50 \%$ & $50 \%$ \\
Norvēǵija & $50 \%$ & $50 \%$ \\
Zviedrija & $49 \%$ & $49 \%$ \\
Austrija & Stumbrs (50\%), zari, skujas, saknes $(48 \%)$ & $48 \%$ \\
Belǵgija & $50 \%$ & $50 \%$ \\
Francija & $47.5 \%$ & $47.5 \%$ \\
\hline
\end{tabular}


1.4. tabulas nobeigums

\begin{tabular}{ccc}
\hline Valsts & Skujkoki & Lapkoki \\
\hline Vācija & $50 \%$ & $50 \%$ \\
Nīderlande & $51 \%$ & $48 \%$ \\
Čehija & $49 \%$ & $48 \%$ \\
Polija & $47 \%$ & $47 \%$ \\
Rumānija & $47 \%$ & $47 \%$ \\
Itālija & $47 \%$ & $47 \%$ \\
Spānija & $50.7 \%$ & $48.5 \%$ \\
Igaunija & $47 \%$ & $47 \%$ \\
Lietuva & $51 \%$ & $48 \%$ \\
\hline
\end{tabular}

Novērtējot kokaudžu oglekḷa krājumus, zinātniskajā literatūrā daudzos gadījumos vienkāršoti tiek pieņemts, ka oglekḷa saturs koka biomasā ir 50\%. Tomēr nesenākie pētîjumi apliecina, ka šis pien̦ēmums nav gluži precīzs, un oglekḷa saturs būtiski atšķiras starp koku sugām, kā arī starp dažādām koku frakcijām (Thomas \& Martin, 2012). Piemēram, koku celma/sakṇu biomasas vidējais oglekḷa saturs ir $48.1 \%$, kas ir zemāks nekā virszemes biomasas frakciju vidējais oglekḷa saturs, kas ir 50\% (Ritson \& Sochacki, 2003). Dažos pētījumos ir pierādīts, ka vispārīgi pieņemtais oglekḷa satura pieņēmums var radīt vidēji 5\% kḷūdu kokaudžu oglekļa uzkrājuma aprēķinos. Piemēram, tropu mežos kopējais oglekḷa apjoms tiek pārvērtēta par apmēram 3.3 - 5.3\% (Martin \& Thomas, 2011), bet mērenās joslas mežos akumulētā oglekḷa apjoma kḷūda varētu būt robežās no 4-6\%, atkarībā no dominējošās koku sugas (Jones \& O’Hara, 2012; Thomas \& Malczewski, 2007).

Arī Latvijā ir veikti pētījumi par dažādu biomasas frakciju oglekḷa saturu, bet tie veikti tikai atsevišķu koku sugu jaunaudzēs. Piemēram, baltalkšņa jaunaudzēs oglekḷa saturs absolūti sausas koksnes dažādās virszemes frakcijās (stumbrs, zari, lapas, miza) svārstās no 47.2\% stumbra koksnē līdz 52.6\% koku lapās, bet vidējais oglekḷa saturs absolūti sausas koksnes sakṇu biomasā ir konstatēts mazāks nekā koka virszemes frakcijās, attiecīgi 47.0\%. (Bārdulis et al., 2011). Citā pētījumā, kurš veikts līdz 40 gadus vecās citu koku sugu audzēs, vidējais oglekḷa saturs parastās priedes sakṇu biomasā meža zemē novērtēts vidēji 48.9\%, bet apmežotā lauksaimniecības zemē - 49.5\%; turpretī bērza sakṇu biomasas oglekḷa saturs apmežotā lauksaimniecības zemē ir 47.3\% (Andis Bārdulis et al., 2017). Jansons et al. (2017) konstatēja priedes oglekḷa satura būtisku ( $\mathrm{p}<0.001$ ) palielināšanos no 48.2\% līdz 51.7\% sakṇu biomasā, pieaugot koka vecumam. Priedes, egles un bērza 10-12 gadus vecos stādījumos lauksaimniecības zemēs apkopoti dati par oglekḷa saturu virszemes un sakņu biomasas frakcijās (stumbra koksne, stumbra miza, zari, saknes, lapas un skujas), kur tas priedei svārstās robežās no 50.99-51.9\%, eglei $49.81-50.51 \%$, bet bērzam $49.7-52.21 \%$ (Daugaviete et al., 2008). IPCC vadlīniju SEG uzskaites metodika (Eggleston et al., 2006) rekomendē pielietot koksnes oglekḷa īpatsvara vērtības, piemērojot tās atkarībā no klimatiskajiem reǵioniem. Arī skujkokiem un lapkokiem mērenās un boreālās joslas mežos vadlīnijas iesaka lietot atšķirīgas oglekḷa noklusētās vērtības. Tomēr, kopš pēdējo vadlīniju izstrādes, ir pagājis ilgs laiks un šobrīd ir pieejamas precizētas, dažādām koku sugu grupām piemērojamas oglekḷa īpatsvara vērtības, kuras aprēķinātas no daudz plašākiem koku augšanas apstākḷiem un reǵioniem. Apkopojot dažādu pētījumu rezultātus secināts, ka oglekḷa saturs dažādu koku sugu dzīvajā biomasā mērenās joslas mežos un boreālajos mežos var būt robežās no 43.4-55.6\% (Thomas \& Martin, 2012). N̦emot vērā jaunākās atziņas par koksnes oglekḷa saturu secināts, ka IPCC vadlīniju ieteiktās oglekḷa satura vērtības, tropiskajos mežos pārvērtē oglekḷa uzkrājumus par apmēram 3.3\% jeb vidēji 4.1 t oglekḷa ha ${ }^{-1}$ (Martin \& Thomas, 2011). Salīdzinot ar citiem kḷūdu rašanās avotiem, oglekḷa satura precizēšanas ietekme uz kopējiem oglekḷa uzkrājumiem ir viegli izmērāma, tomēr veicot zinātniskās literatūras analīzi nav atrodama informācija, ka Eiropas mežos tas būtu darīts. Nacionālajos 
SEG inventarizācijas ziņojumos (UNFCCC, 2018) piln̄ibā vai dal̦ēji IPCC vadlīniju ieteiktās vērtības mērenās un boreālās joslas mežiem lieto 8 no apskatītajām 15 valstīm (1.4. tabula). Somija, Norvēǵija, Beḷgija un Vācija lieto vispārpien̦emto oglekl̦a īpatsvara vērtību $50 \%$, bet Zviedrija, Francija un Spānija lieto savas oglekḷa satura vērtības.

Nacionālajos SEG inventarizācijas ziņojumos (UNFCCC, 2018) 10 no apskatītajām 15 valstīm skujkokiem un lapkokiem lieto vienādas oglekḷa īpatsvara vērtības (1.4. tabula). Apjomīgā literatūras analīzē, izvērtējot 31 dažāda pētījuma rezultātus no visas pasaules, par oglekḷa satura izmaiṇām starp dažādiem reǵioniem, skujkoku un lapkoku grupām secināts, ka neatkarīgi no klimatiskā reǵiona oglekḷa saturs skujkoku $(50.8 \% \pm 0.7 \%)$ koksnē ir būtiski lielāks nekā lapkokiem $(47.7 \% \pm 0.3 \%)$ (Thomas \& Martin, 2012). Tāpēc vienāda oglekḷa satura vērtību lietošana skujkokiem un lapkokiem nav zinātniski pamatota.

Tā kā līdz mūsdienām joprojām nav pētījumu par koksnes oglekḷa saturu kāds būtu jālieto hemiboreālajā mežu joslā, mūsu pētījumā pieņemts lietot skujkoku un lapkoku vidējās oglekḷa satura vērtības, attiecīgi 50.8\% $\pm 0.6 \%$ un $48.8 \% \pm 0.6 \%$ kuras Thomas un Martin (2012) iesaka lietot mērenās un boreālās mežos. 


\section{MATERIĀLS UN METODIKA}

\subsection{Empīriskā materiāla raksturojums}

Empīriskais materiāls, Latvijas saimnieciski nozīmīgāko koku sugu parastās priedes (Pinus sylvestris L.), parastās egles (Picea abies (L.) H. Karst., bērzu (Betula pendula Roth un Betula pubescens Ehrh.) un parastās apses (Populus tremula L.) virszemes un sakņu biomasas vienādojumu izstrādei un oglekḷa uzkrājumu koka biomasā aprēķiniem, ievākts 124 meža nogabalos laikposmā no 2010.-2014. gadam. Mežaudžu atrašanās vietas izvēlētas dažādās Latvijas vietās, pārstāvot daudzveidīgus augšanas apstākḷus un atšksirīgas koku populācijas (2.1. attēls). Visas izvēlētās mežaudzes izvietotas akciju sabiedrības 'Latvijas valsts meži" Ziemel̦latgales, Vidusdaugavas, Zemgales un Ziemel̦kurzemes plānošanas reǵionos. Atlasītie nogabali (35 kārpainā un purva bērza, 34 parastās priedes, 28 parastās apses, 27 parastās egles) galvenokārt izvietoti sausās un susinātās minerālaugsnēs, tādējādi reprezentējot lielāko daļu Latvijas meža augšanas apstākļu. Tikai 6\% gadījumos meža nogabali atlasīti slapjās minerālaugsnēs un susinātās kūdras augsnēs. Mežaudzes slapjās kūdras augsnēs (kūdras slānis lielāks par $30 \mathrm{~cm}$ ) no pētījuma tika izslēgtas, jo šādās vietās augsta ūdens līmeņa rezultātā bija apgrūtināta kvalitatīva empīriskā materiāla ievākšana.

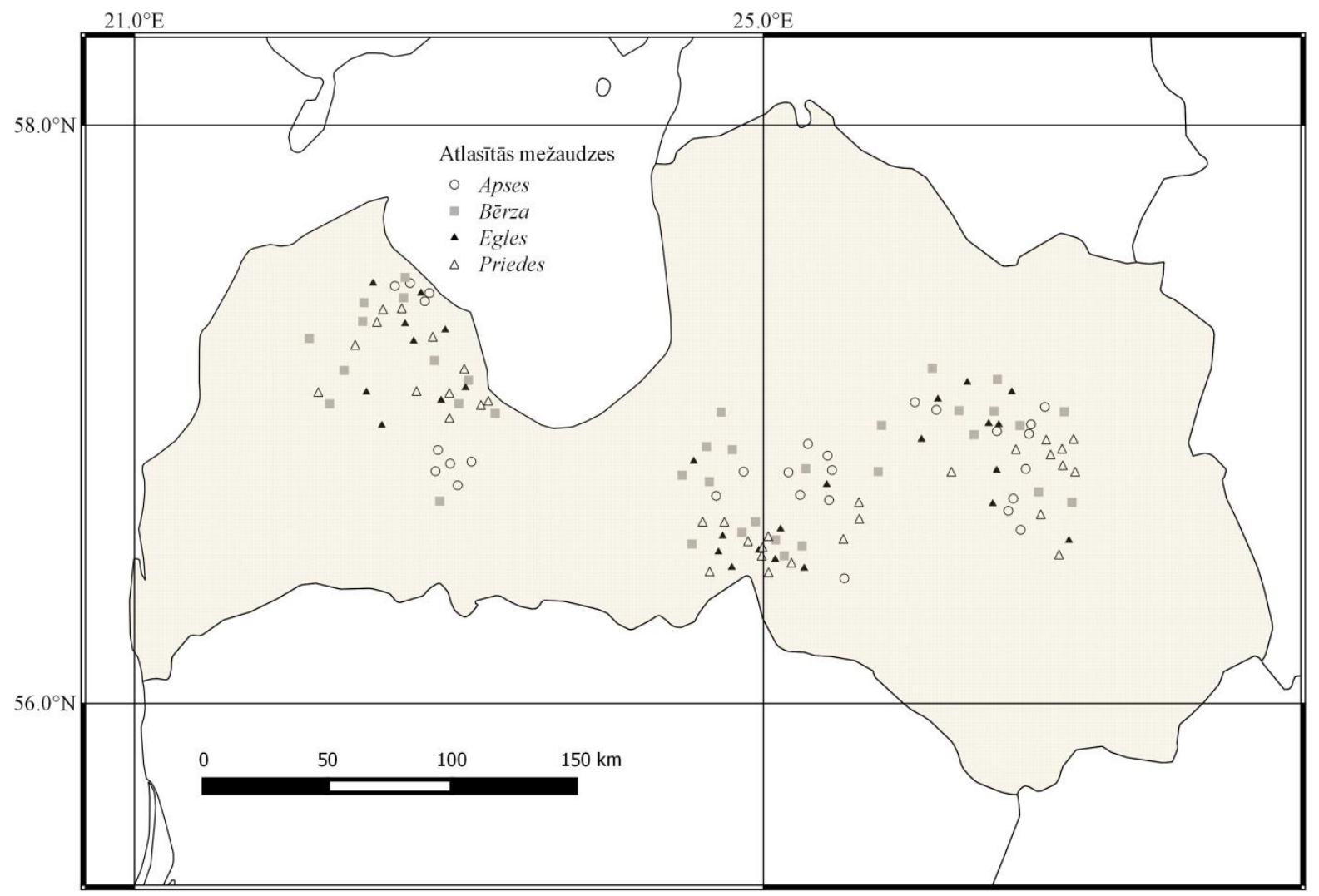

\section{1. att. Pētījumu objektu izvietojums Latvijas teritorijā.}

Katrai pêtījumā iekļautajai koku sugai meža nogabali atlasīti, pārstāvot vienādā skaitā jaunaudzes, vidēja vecuma audzes, briestaudzes un pieaugušas audzes, kā arī koku sugai tipiskākos meža tipus. Visos atlasītajos nogabalos valdošās koku sugas īpatsvars bija lielāks par $70 \%$. Lai raksturotu atlasītās mežaudzes, katrā nogabalā izvietots apḷlveida parauglaukums ar platību $500 \mathrm{~m}^{2}$; parauglaukumi subjektîvi izvietoti audzes vietās, kas visprecīzāk raksturo visu nogabalu un to centrs atradās tālāk par 50 m no nogabala ārējās robežas (2.1. tabula). 


\begin{tabular}{ccccccc}
\hline Valdošā suga & $\begin{array}{c}\text { Nogabalu } \\
\text { skaits, } \\
\text { gab }\end{array}$ & $\begin{array}{c}\text { Sugas } \\
\text { ipatsvars, } \%\end{array}$ & $\begin{array}{c}\text { Caurmērs, } \\
\text { cm }\end{array}$ & $\begin{array}{c}\text { Augstums, } \\
\mathrm{m}\end{array}$ & $\begin{array}{c}\text { Šķērslaukums, } \\
\mathrm{m}^{2} \mathrm{ha}^{-1}\end{array}$ & $\begin{array}{c}\text { Vecums, } \\
\text { gadi }\end{array}$ \\
\hline Priede & 34 & $70-100$ & $1.3-40.3$ & $1.4-30.7$ & $0.4-49.7$ & $6-141$ \\
Egle & 27 & $70-100$ & $1.6-34.1$ & $1.8-27.7$ & $0.6-44.9$ & $8-97$ \\
Bērzs & 35 & $70-100$ & $2.8-32.3$ & $5.2-29.6$ & $0.9-44.4$ & $8-92$ \\
Apse & 28 & $80-100$ & $2.1-30.6$ & $3.4-30.4$ & $0.5-45.2$ & $5-76$ \\
\hline
\end{tabular}

Ierīkotajos parauglaukumos katram kokam uzmērīts krūšaugstuma caurmērs un 15 dažādu dimensiju kokiem no katras sugas - arī augstums. Ja koku skaits parauglaukumā ir mazāk, tad augstums mērīts visiem kokiem. Pēc augstuma mērījumiem katrai sugai atsevišķi konstruēta augstumlīkne, pēc kuras aprēķināts augstums visiem pārējiem parauglaukumā uzmērītajiem šīs sugas kokiem.

Pēc uzmērīšanas katrā parauglaukumā nozāg̣ēšanai atzīmēti 3 dažādu dimensiju I, II un III Krafta klases paraugkoki (2.2. attēls). Bojātie un trupējušie koki, kā arī koki ar dubultgalotnēm netika izvēlēti kā paraugkoki.

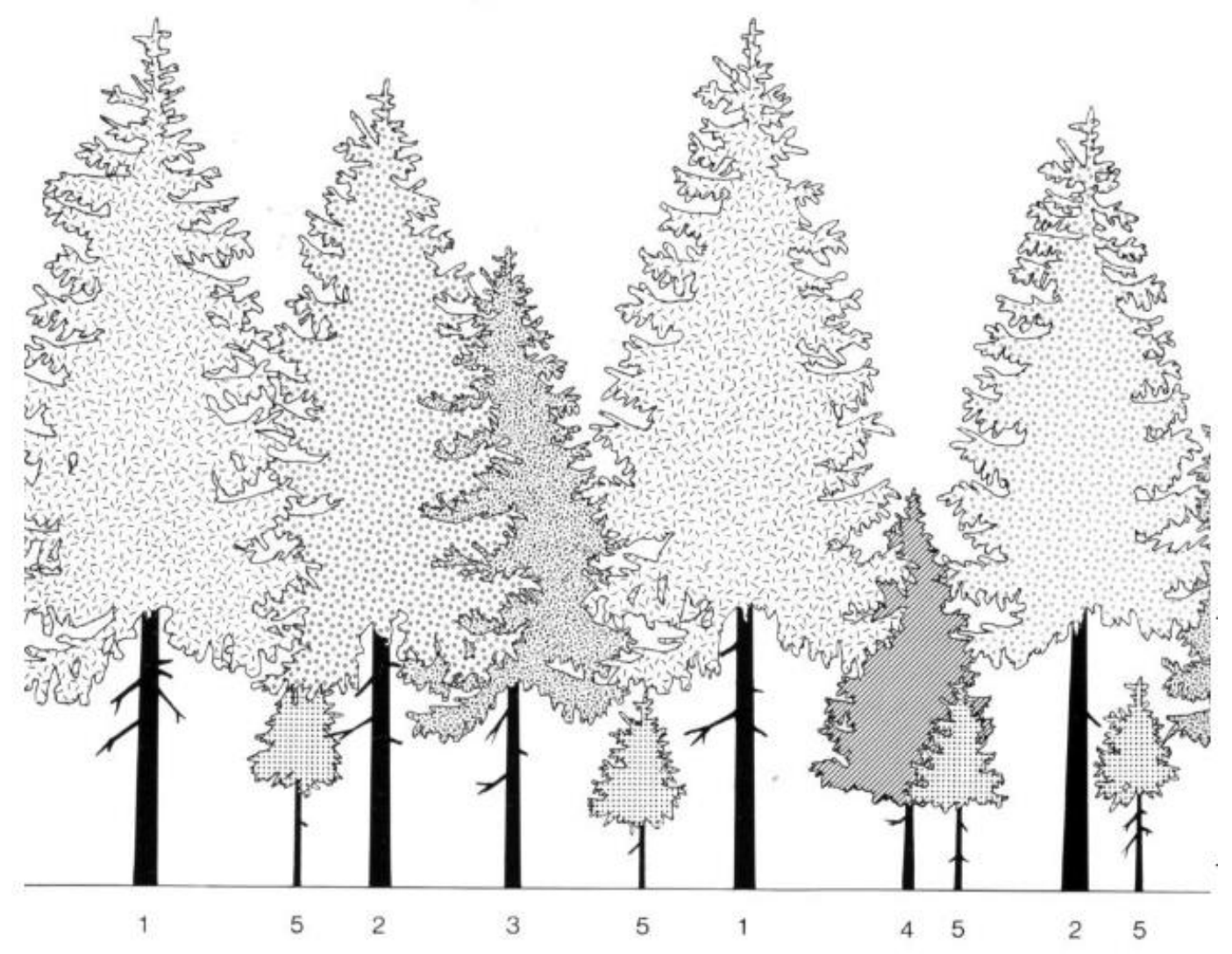

2.2. att. Koku klasifikācija pēc ārējā izskata un vainaga īpašībām (FAO, 2014)

1 - virsvaldu koki, 2 - valdošie koki, 3 - līdzvaldu koki, 4 - nomāktie koki, 5 - atmirušie un atmirstošie koki 


\subsection{Koku virszemes biomasas empīriskā materiāla ievākšana un apstrāde}

Virszemes biomasas aprēķiniem empīriskais materiāls ievākts no vēla rudens līdz agram pavasarim, periodā, kad lapu koki ir bezlapu stāvoklī, koku jaunie dzinumi ir nobrieduši un vairs nenotiek aktīva koka augšana. Kopā virszemes biomasas vienādojumu izstrādei ievākts empīriskais materiāls no 372 kokiem (2.2. tabula).

2.2. tabula

\section{Paraugkoku raksturojums virszemes biomasas aprēḳiniem}

\begin{tabular}{cccccccccc}
\hline \multirow{2}{*}{ Koku suga } & \multirow{2}{*}{ Koku skaits } & $\mathrm{D}, \mathrm{cm}$ & \multicolumn{9}{c}{$\mathrm{H}, \mathrm{m}$} \\
& & Vidēji & Std. & Min. & Maks. & Vidēji & Std. & Min. & Maks. \\
\hline Priede & 102 & 19 & 9.4 & 1.5 & 45.2 & 17.3 & 9.2 & 1.9 & 34.5 \\
Egle & 81 & 17.5 & 9 & 2.3 & 36.3 & 16.6 & 8.9 & 2.8 & 30.8 \\
Bērzs & 105 & 14.7 & 7.5 & 2.7 & 37.1 & 18.1 & 8.1 & 4.8 & 32.3 \\
Apse & 84 & 13.8 & 8.3 & 2.7 & 34 & 16.6 & 8.5 & 3.7 & 29.9 \\
\hline
\end{tabular}

Pirms paraugkoka nozāgeěšanas katram kokam uzmērīts krūšaugstuma caurmērs un celma augstums, tos atzīmējot ar krāsu uz stumbra virsmas. Celma augstums visiem kokiem mērīts no zemes virsmas. Tas definēts kā 1\% no koka augstuma, kas nomērīts pirms koka nozāǵēšanas. Celma augstums ir ar̄̄ vieta, kur koks sadalās virszemes un celma/sakṇu biomasas frakcijās.

Pēc koka nozāgeēšanas tā zaļais vainags stumbra garenvirzienā sadalīts trijās vienādās daḷās. No katras daļas vidus marķêts viens vidēja izmēra zars, kuri kopā izmantoti tālākām analīzēm, lai noteiktu vidējo ūdens īpatsvaru koka vainagā. No sauso zaru daļas vidus izvēlēts tikai viens paraugzars, kurš marḳēts identiski. Pēc tam stumbrs rūpīgi atzarots un visi dzīvie un sausie zari atsevišksi nosvērti ar svariem, iekarinātiem pārvietojamā trijkājī (2.3. attēls). Lielākajiem kokiem zari svērti ar Kern HCB 99K50, $99 \mathrm{~kg} \pm 0.05$ svariem, bet mazākajiem Kern HDB 10K10N, $10 \mathrm{~kg} \pm 0.01$. Pēc svēršanas zaru paraugi iepakoti plastmasas maisos un nogādāti laboratorijā sausas masas noteikšanai.

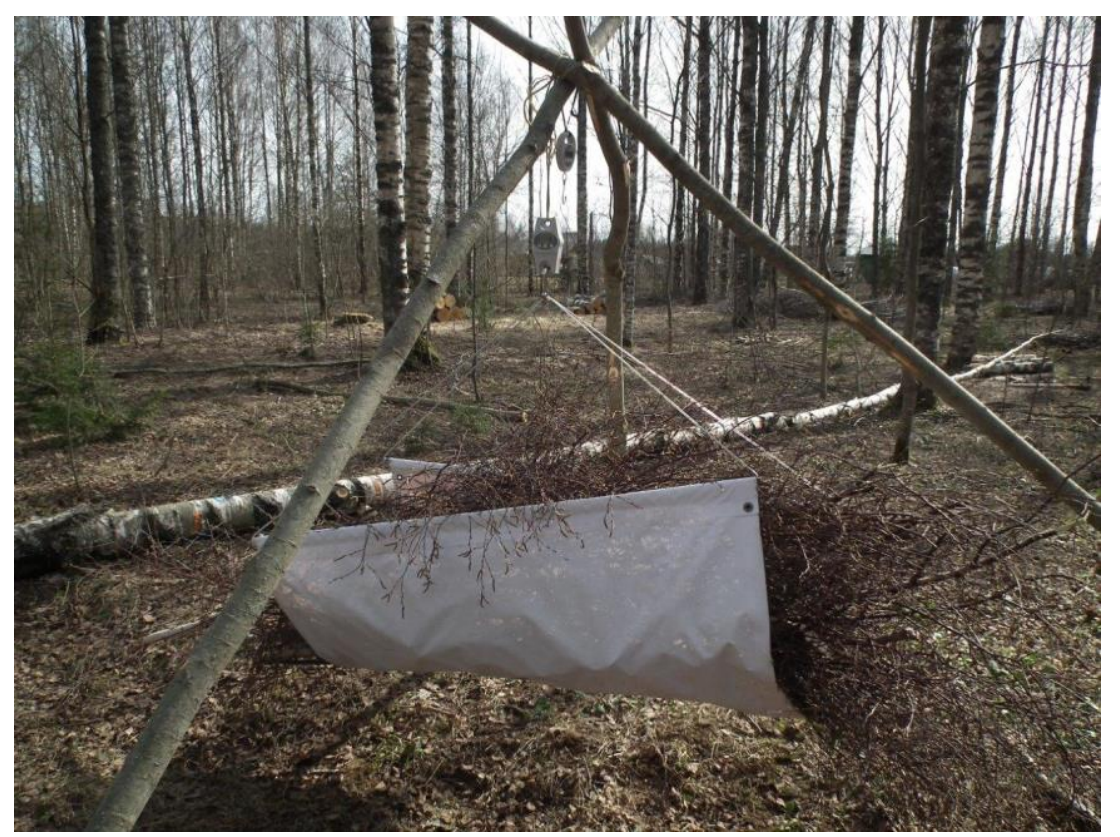

2.3. att. Zaru svēršanas process bērza nogabalā 
Laboratorijā zaru paraugi nosvērti un likti žāvēties $103{ }^{\circ} \mathrm{C}$ grādu temperatūrā līdz nemainīgai to masai. Ja kādu iemeslu dēḷ paraugus uzreiz pēc nogādāšanas laboratorijā nebija iespējams nosvērt tie uzglabāti aukstumkamerā. Paraugu relatīvais mitrums noteikts pēc formulas (2.1). Visa koka dzīvo un sauso zaru biomasa aprēķināta pēc raksturojošo zaru paraugu dabiski mitras masas un absolūti sausas masas attiecības.

$$
W=\left(m_{1}-m_{2}\right) / m_{1} \times 100
$$

kur:

$W$ - parauga relatīvais mitrums, \%;

$m_{1}$ - parauga masa mitrā stāvoklī, g;

$m_{2}-$ parauga masa absolūti sausā stāvoklī, g.

Uz nogāztā koka virsmas ar krāsu izveidotas atzīmes ik pa $1 \mathrm{~m}$ (kokiem, kuru stumbru garums ir līdz $20 \mathrm{~m}$ ) vai ik pa $2 \mathrm{~m}$, (ja stumbra garums ir $20 \mathrm{~m}$ un vairāk) un precīzi nomērīts stumbra kopējais garums. Koka stumbrs iezīmētajās vietās sadalīts nogriežņos jeb sekcijās. Katrā stumbra griezuma vietā, papildus arī pirmās sekcijas vidū un $1.3 \mathrm{~m}$ augstumā, izzāĝêtas apmēram $2-2.5 \mathrm{~cm}$ biezas koksnes ripas. Šksērsgriezuma laukuma aprēķiniem katrai koksnes ripai izmērīts caurmērs ar un bez mizas divos savstarpēji perpendikulāros virzienos. Lai aprēksinātu stumbra vidējo reducēto blīvumu, no katra stumbra šķērsgriezuma ripas sagatavoti paraugi jeb ripas segmenti blīvuma mērīšanai. Blīvuma segmentu sagatavošana veikta pēc attēlotās shēmas (2.4. attēls).

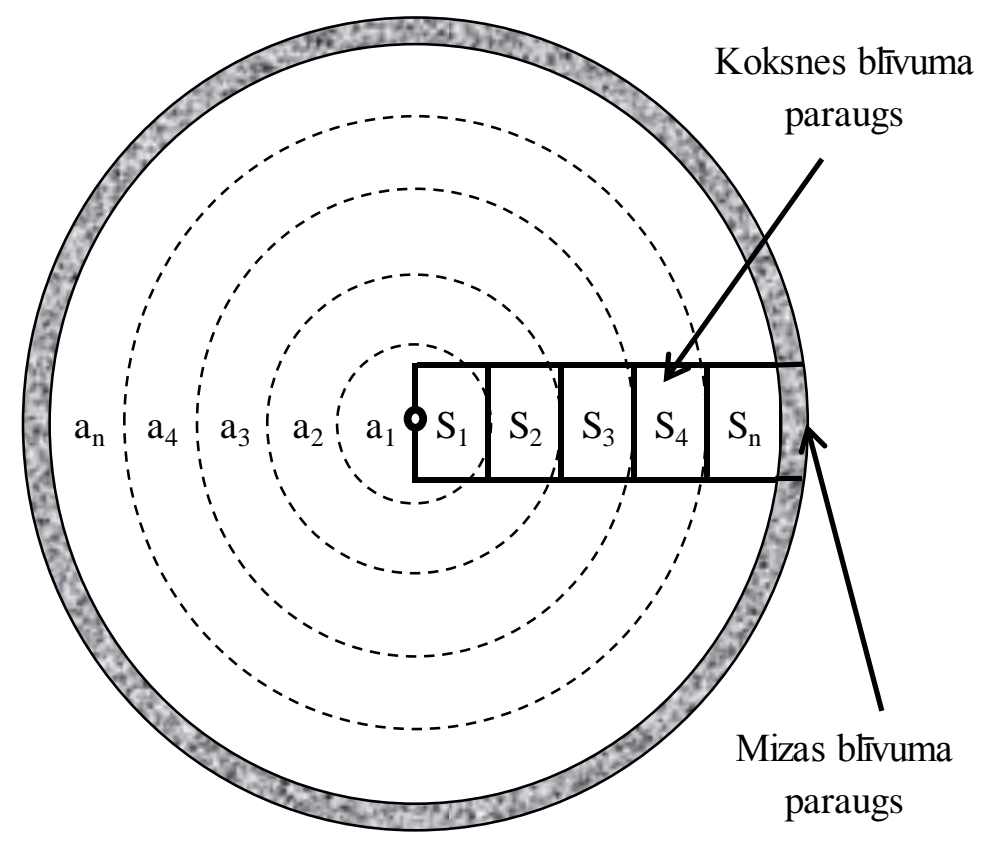

\section{4. att. Blīvuma paraugu novietojums stumbra šksērsgriezuma ripās}

S - apzīmē blīvuma paraugu, bet a - apzīmē paraugam atbilstošo ripas platību

Blīvuma segmenta platums virzienā no ripas centra uz mizu bija stingri noteikts $20 \mathrm{~mm}$. To skaits un pēdējā segmenta platums bija atkarīgs no šķērsgriezuma ripas rādiusa. Segmenta biezums bija vienāds ar ripas biezumu, bet tā garums nepārsniedza $30 \mathrm{~mm}$. Pēdējais segments (vistuvāk mizai) tika nomizots un, gadījumos ja tā platums bija mazāks par $5 \mathrm{~mm}$, netika atdalīts no iepriekšējā segmenta. Stumbra šķērsgriezuma ripas, kuru caurmērs mazāks par $20 \mathrm{~mm}$, tika nomizotas, bet netika dalītas sīkākos segmentos. Šķērsgriezuma ripām ar 
diametru mazāku par $5 \mathrm{~mm}$, blīvums tika mērīts tās nemizojot, jo mizu nebija iespējams precīzi atdalīt no koksnes.

Pirms koksnes un mizas segmentu blīvuma mērǐšanas tie uz 24 stundām iemērkti ūdeni, lai to neuzsūktu mērīšanas procesā (Ilic et al., 2000). Paraugu blīvums mērīts ar Precisa XB 220A laboratorijas svariem, kas aprīkoti ar Precisa blīvuma mērīšanas komplektu (partijas numurs: 350-8556) divos atkārtojumos (2.5. attēls). Pirms katra atkārtojuma paraugs nosusināts ar mīkstu papīru. Ja starp mērījumu atkārtojumiem konstatēta liela starpība, tad veikts vēl trešais mērījums, tādējādi samazinot sistemātisko un gadījuma kḷūdu rašanos. Koksnes un mizas segmentu reducētā blīvuma aprēķiniem visi paraugi žāvēti $103{ }^{\circ} \mathrm{C}$ temperatūrā līdz tika sasniegta nemainīga to masa. Paraugu sausa masa noteikta uzreiz pēc to izṇemšanas no žāvēšanas kameras, kamēr tie nav piesaistījuši gaisā esošo mitrumu. Reducētais blīvums aprēķināts pēc formulas (2.2).

$$
\rho_{r}=\frac{\rho \times m_{2}}{m_{1}}
$$

kur:

$\rho_{r}$ - parauga reducētais blīvums, $\mathrm{g} \mathrm{cm}^{-3}$;

$\rho$ - parauga blīvums mitrā stāvoklī, $\mathrm{g} \mathrm{cm}^{-3}$;

$m_{1}$ - parauga masa mitrā stāvoklī, g;

$m_{2}$ - parauga masa absolūti sausā stāvoklī, g.

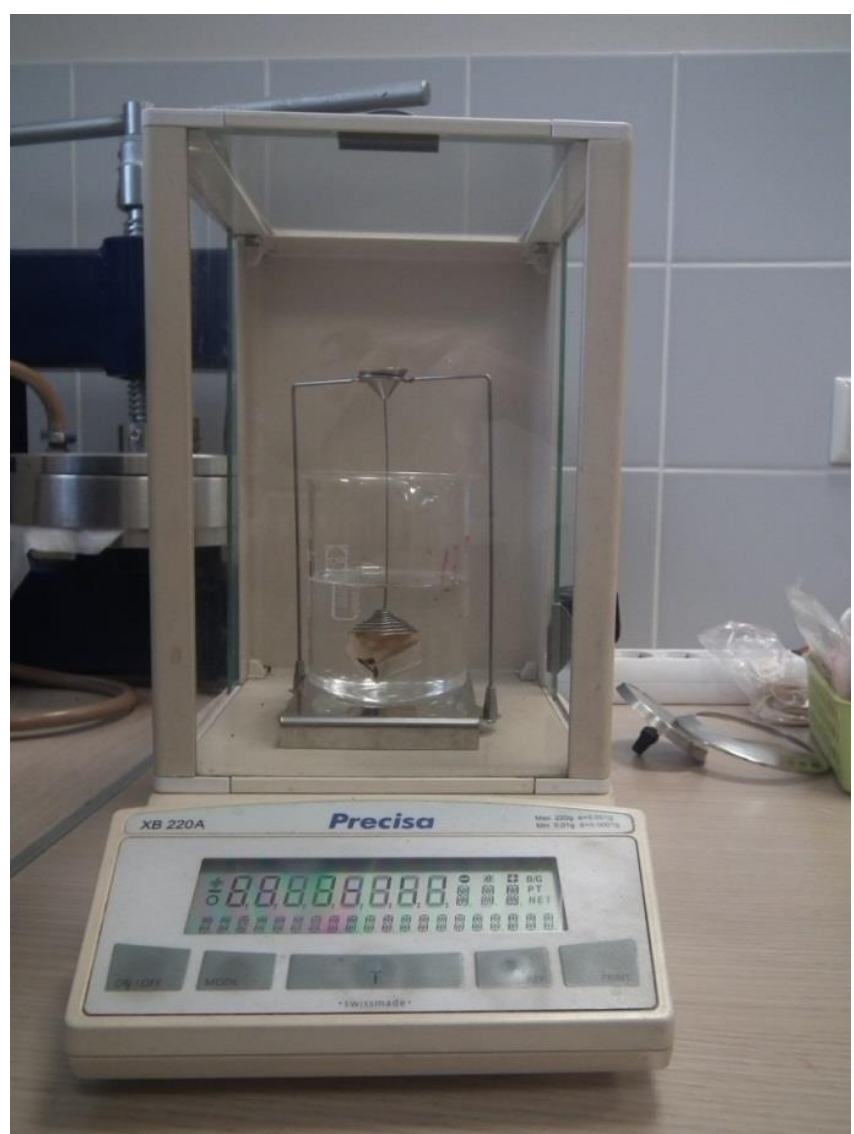

2.5. att. Koksnes parauga blīvuma mērīšanas process 
Stumbra sekciju tilpuma aprēķiniem izmantotas katras šķērsgriezuma vietas diametra mērījumu rezultāti divos savstarpēji perpendikulāros virzienos. Katras stumbra sekcijas tilpums aprēķināts pēc formulas (2.3), līdzīgi kā to darīja Smith et al., (2014) aprēķinot bērza stumbra biomasu.

$$
\mathrm{V}_{\mathrm{s}}=\frac{\mathrm{l}_{\mathrm{s}}\left(\mathrm{g}_{1}+\mathrm{g}_{2}\right)}{2}
$$

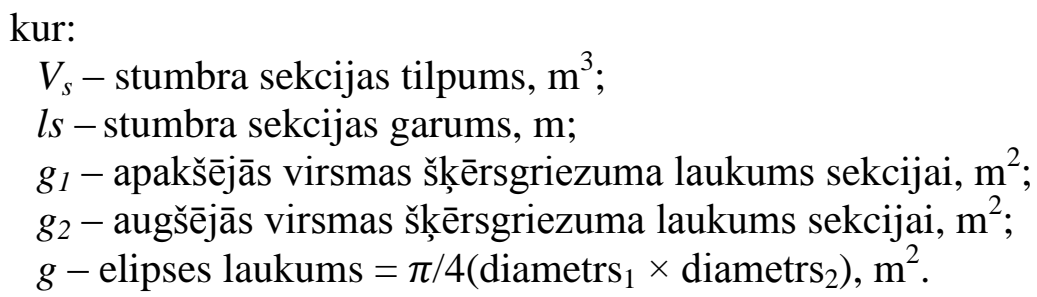

Katras stumbra sekcijas biomasa aprēķināta, reizinot tās tilpumu ar vidējo reducēto blīvumu, kurš aprēķināts kā vidējais aritmētiskais no abos galos esošo šķērsgriezuma ripu vidējiem reducētajiem blīvumiem. Galotnes sekcijai blīvums aprēķināts tikai pēc vienas apakšejās šķērsgriezuma ripas vidējā reducētā blīvuma. Vidējā svērtā aprēķina formula (2.4) lietota, aprēķinot katras šķērsgriezuma ripas vidējo blīvumu no koksnes un mizas segmentiem un tiem atbilstošajām platībām uz stumbra šķērsgriezuma ripas (2.4. attēls). Visa stumbra kopējā biomasa aprēķināta summējot individuālu sekciju biomasu.

$$
\rho_{\text {ripa }}=\frac{S_{1} \times a_{1}+S_{2} \times a_{2}+S_{n} \times a_{n}+S_{m} \times a_{m}}{a_{1}+a_{2}+a_{n}+a_{m}}
$$

kur:

$\rho_{\text {ripa }}$ - stumbra šķērsgriezuma ripas vidējais reducētais blīvums, $\mathrm{g} \mathrm{cm}^{-3}$;

$\mathrm{S}_{1}, \mathrm{~S}_{2}, \mathrm{~S}_{\mathrm{n}}-$ koksnes paraugu reducētais blīvums, $\mathrm{g} \mathrm{cm}^{-3}$;

$\mathrm{S}_{\mathrm{m}}-$ mizas parauga reducētais blīvums, $\mathrm{g} \mathrm{cm}^{-3}$;

$a_{1}, a_{2}, a_{n}-$ koksnes parauga aizņemtais laukums stumbra šksērsgriezumā, $\mathrm{cm}^{2}$;

$\mathrm{a}_{\mathrm{m}}-$ mizas parauga aiznemtais laukums stumbra šksērsgriezumā, $\mathrm{cm}^{2}$.

\subsection{Koku celma/sakṇu biomasas empīiskā materiāla ievākšana un apstrāde}

Koku celms un saknes atrakti nākamajā vasarā pēc koka nozāğêšanas. Datu paraugkopu kopā veido 141 atlasīti paraugkoki (37 parastās priedes, 29 parastās egles, 42 bērza un 33 parastās apses), pārstāvot dažādas krūšaugstuma caurmēra pakāpes, koku augstumu un vecumu grupas katrai pētîjumā ietvertajai koku sugai (2.3. tabula). Koku saknu biomasa atrakta tiem pašiem kokiem kuriem iepriekš novērtēta virszemes biomasa. Lai samazinātu smalko sakņu zudumu, visa sakṇu sistēma katram kokam rakta tikai manuāli ar rokas darbarīkiem. Saknes, kuru caurmērs ir mazāks par $2 \mathrm{~mm}$ tiek dēvētas par koka uzsūcošajām saknēm un ar parastajām metodēm ir ļoti grūti atdalāmas no augsnes (Eggleston et al., 2006). Tāpēc darba procesā mēǵināts izrakt tik daudz uzsūcošo sakṇu cik iespējams, bet pilnībā izraktas tikai tās saknes, kuru caurmērs pārsniedza $2 \mathrm{~mm}$. 
Paraugkoku raksturojums celma/sakṇu biomasas aprēḳiniem

\begin{tabular}{|c|c|c|c|c|c|c|}
\hline Koku suga & Koku skaits & Parametrs & Vidēji & Std. & Min. & Maks. \\
\hline \multirow{3}{*}{ Priede } & \multirow{3}{*}{37} & $\mathrm{D}, \mathrm{cm}$ & 15.1 & 9.7 & 1.5 & 45.3 \\
\hline & & $\mathrm{H}, \mathrm{m}$ & 13.0 & 9.4 & 1.9 & 34.5 \\
\hline & & vecums, gadi & 35.3 & 30.6 & 6.0 & 119.0 \\
\hline \multirow{3}{*}{ Egle } & \multirow{3}{*}{29} & $\mathrm{D}, \mathrm{cm}$ & 13.7 & 8.1 & 4.0 & 30.5 \\
\hline & & $\mathrm{H}, \mathrm{m}$ & 13.1 & 8.3 & 4.0 & 27.7 \\
\hline & & vecums, gadi & 30.3 & 22.2 & 11.0 & 72.0 \\
\hline \multirow{3}{*}{ Bērzs } & \multirow{3}{*}{42} & $\mathrm{D}, \mathrm{cm}$ & 12.0 & 7.0 & 2.7 & 31.7 \\
\hline & & $\mathrm{H}, \mathrm{m}$ & 15.9 & 8.8 & 4.9 & 30.9 \\
\hline & & vecums, gadi & 26.7 & 21.2 & 8.0 & 72.0 \\
\hline \multirow{3}{*}{ Apse } & \multirow{3}{*}{33} & $\mathrm{D}, \mathrm{cm}$ & 10.9 & 8.1 & 2.8 & 34.1 \\
\hline & & $\mathrm{H}, \mathrm{m}$ & 13.1 & 7.6 & 3.7 & 29.7 \\
\hline & & vecums, gadi & 16.2 & 13.2 & 6.0 & 46.0 \\
\hline
\end{tabular}

Pēc izrakšanas un transportēšanas uz tālāko apstrādes vietu, koka sakṇu sistēma rūpīgi mazgāta, izmantojot augstspiediena ūdens sūkni, lai atbrīvotos no palikušās augsnes dalininām (2.6. attēls). Absolūti sausas celma/sakṇu biomasas aprēķināšanai sakṇu sistēma sadalīta trijās frakcijās:

- celma daļa - virszemē un augsnē esošā monolītā, atsevišşāàs saknēs nediferencētā daḷa (Liepa \& Blija, 2008);

- balstsaknes - visas koka saknes, kuru caurmērs pārsniedz 20 mm;

- sīkās saknes - visas atraktās koka saknes, kuru caurmērs ir mazāks par 20 mm.

Kopējā celma un sakņu masa noteikta, nosverot katru frakciju atsevišķi ar tiem pašiem iekarināmajiem lauka svariem, kuri izmantoti koku zaru svēršanai. Absolūti sausas masas aprēķiniem no celma un saknēm ievākti paraugi relatīvā mitruma noteikšanai. No celma daļas vidus izzāgèts viens paraugs, no balstsaknēm izzāgeèti trīs atšķirīga diametra sakṇu paraugi, bet trīs pilna garuma saknes mazākas par $20 \mathrm{~mm}$ izvēlētas kā sīkās saknes reprezentējošs paraugs. Visi ievāktie paraugi uzreiz nosvērti un tad žāvēti $103{ }^{\circ} \mathrm{C}$ temperatūrā līdz nemain̄̄gai to masai. Paraugu relatîvais mitrums aprēksināts pēc (2.1) izteiksmes. Koka celma/sakṇu biomasa aprēķināta, saskaitot celma, balstsakṇu un sīko sakṇu kopējo biomasu, kas katrai frakcijai noteikta pēc raksturojošo paraugu dabiski mitras - absolūti sausas masas attiecības. 


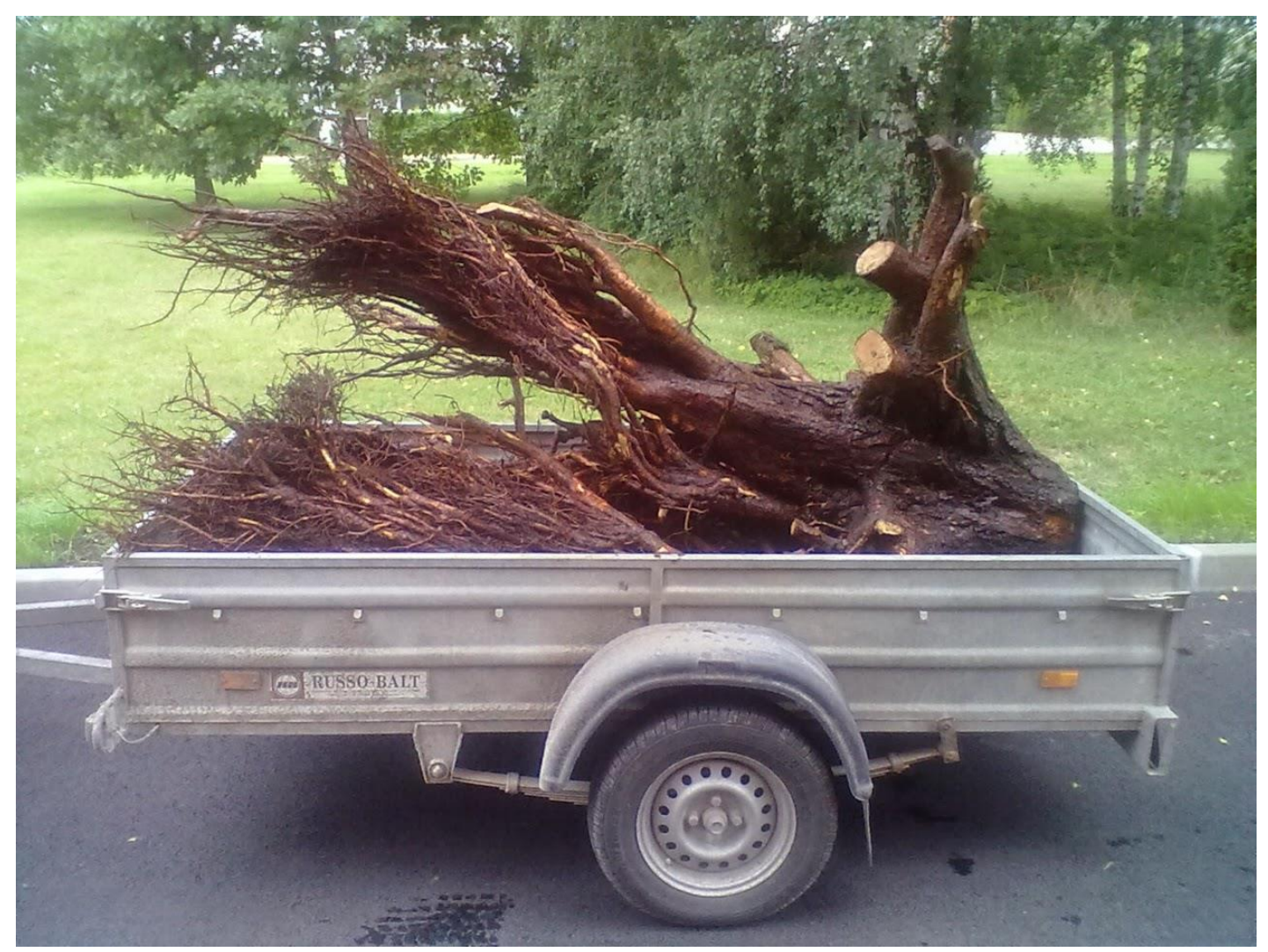

2.6. att. Atrakta un nomazgāta parastās priedes sakņu sistēma

\subsection{Vienādojumu izstrāde}

Latvijas MRM uzkrāj datus par individuālu koku D un H, tāpēc šīs viegli izmērāmās koka pazīmes pêtījumā izvēlētas kā mainīgās vērtības, lai radītu ērti pielietojamus un praktiskus vienādojumus. Dažkārt kā mainīgās vērtības vienādojumos papildus D un H tiek lietots arī koka vecums vai dažādi vainaga parametri, bet mūsu MRM pagaidām šādu informāciju neievāc individuālu koku līmenī. Pēc apjomīgas literatūras analīzes, galarezultātā izvēlētas trīs matemātiskās izteiksmes $(2.5,2.6$ un 2.7), aprēķinot koka stumbra biomasu (SB), dzīvo un sauso zaru biomasu (BB), kopējo virszemes biomasu (AGB) un kopējo celma daḷas un sakṇu biomasu (BGB). AGB aprēķināta saskaitot SB un BB (skujas un čiekuri ir iekļauti skujkokiem, bet lapas nav iekḷautas lapkokiem), kamēr kopējā BGB ir aprēķināta, saskaitot celma, balstsakṇu un sīko sakņu biomasu.

$$
\begin{gathered}
\ln \hat{Y}_{k i}=\ln (a)+b \times \ln (D)+u_{k}+\varepsilon_{k i} \\
\ln \hat{Y}_{k i}=\ln (a)+b \times \ln (D)+c \times \ln (H)+u_{k}+\varepsilon_{k i} \\
\ln \hat{Y}_{k i}=\ln (a)+b \times\left(\frac{D}{D+m}\right)+c \times H+d \times \ln (H)+u_{k}+\varepsilon_{k i}
\end{gathered}
$$

kur:

$\widehat{Y}_{k i}$ - koka $i$ biomasa nogabalā $k, \mathrm{~kg}$;

$D$ - koka krūšaugstuma caurmērs, cm; 
$H$ - koka augstums, m;

$a, b, c$, un $d$-regresijas koeficienti;

$m$ - konstante;

$u$ - randomizētais faktors (anglu val. random effect) nogabalam $k$;

$\varepsilon$ - randomizētais faktors kokam $i$ nogabalā $k$.

Vienādojums (2.5) ir linearizēta pakāpes funkcija, kurā kā vienīgais arguments norādīts D, tikmēr vienādojums (2.6) ir linearizēta pakāpes funkcija ar diviem argumentiem D un $\mathrm{H}$. Abi iepriekšminētie vienādojumi ir visplašāk lietotie zinātniskajā literatūrā, lai modelētu koku biomasu Eiropas mežos (Zianis et al., 2005). Nedaudz savādāks paņēmiens biomasas prognozēšanā ir aprakstīts Zviedrijā veiktajos pētîjumos (Marklund, 1987, 1988), kur, mainot argumentu skaitu vienādojumā (2.7), meklēta piemērotākā mainīgo vērtību kombinācija, kas dotu mazāko iespējamo prognozēšanas kḷūdu. Minētā metode tika pārbaudīta izmantojot plašu un reprezentatīvu empīrisko materiālu no Zviedrijas nacionālā MRM un izstrādātie virszemes biomasas vienādojumi tiek plaši lietoti visās Skandināvijas valstīs (Repola, 2008, 2009).

Datu sākotnējā analīze parādīja, ka palielinoties argumentu D un H vērtībām, palielinās arī atkarīgās pazīmes standartnovirze. Tāpēc, lai nodrošinātu atkarīgo pazīmju dispersiju homogenitāti vienādojumos $(2.5,2.6,2.7)$, ir veikta logaritmiskā transformācija, kas šādos gadījumos ir ieteicama (Claesson, Sahlen, \& Lundmark, 2001; Repola, 2009; Weiskittel et al., 2015; Zianis \& Mencuccini, 2004). Pielietojot transformāciju, tiek panākts, ka atkarīgā pazīme, kas šajā pētījumā ir biomasa, pie mazām un lielām argumentu vērtībām tiek aprēķināta precīzāk.

Tā kā biomasa tika izmērīta un aprēķināta trijiem paraugkokiem katrā no 124 meža nogabaliem jeb parauglaukumiem, tad savāktajam empīriskajam materiālam ir hierarhiska struktūra (Claesson et al., 2001; Repola, 2008, 2009; Temesgen et al., 2015). Tas nozīmē, ka biomasa dažādās koka frakcijās, parasti variē ne vien starp dažādām kokaudzēm, bet arī katras kokaudzes līmenī, piemēram, atkarībā no Krafta klases. Lai gan eksistē arī citas koeficientu novērtēšanas metodes, regresijas koeficientu novērtēšanā visbiežāk izmanto tā saucamo vismazāko kvadrātu metodi. Biomasas vienādojumu izstrādē, pielietojot vismazāko kvadrātu metodi, parasti tiek ignorēta datu hierarhiskā struktūra un vienādojumu koeficientu standartkḷūda tiek atspogulota mazāka nekā tā ir patiesībā (Repola, 2008, 2009). Pētīto argumentu ietekmi hierarhiski strukturētiem datiem precīzāk var novērtēt ar lineāriem jaukta tipa modeļiem (angḷu val. linear mixed models), kuri dod iespēju analizēt koku biomasas datus ne vien atkarībā no pētītajiem argumentiem, bet arī starp dažādiem parauglaukumiem kā arī katras kokaudzes ietvaros (Claesson et al., 2001).

Mūsu pētījumā vienādojumu $(2.5,2.6,2.7)$ koeficienti aprēķināti, izmantojot lineāros jaukta tipa model̦us datorprogrammā R ar pakotni "lme4" (Bates et al., 2015). Atlasītajiem vienādojumiem kā fiksētie faktori (anglu val. fixed factor) norādīit $\mathrm{D}$ un $\mathrm{H}$, bet kā randomizētais faktors (angl̦u val. random factor) izvēlēts parauglaukums jeb meža nogabals. Lai pēc iespējas korektāk aprēķinātu biomasu ļoti maziem un lieliem $(\mathrm{D}>60 \mathrm{~cm})$ kokiem, Marklund $(1987,1988)$ secināja, ka ar D logaritmisko transformāciju vien nepietiek, tā vietā vienādojumā (2.7) ieliekot izteiksmi $\mathrm{D} /(\mathrm{D}+m)$, kur $m$ ir konstante. Konstante katrai koku sugai un koka frakcijai tiek aprēḳināta atsevišķi un tā atspogul̦o labāko korelāciju starp $\ln \widehat{Y}$ un diametra izteiksmi $\mathrm{D} /(\mathrm{D}+m)$ pie dažādām $m$ vērtībām (Marklund, 1987). Šāda pati D izteiksme ir izmantota, izstrādājot Zviedrijas nacionālos celma/sakṇu biomasas vienādojumus (Petersson \& Stahl, 2006), jaunu un pārbiezinātu parastās priedes kokaudžu virszemes biomasas vienādojumus (Repola \& Ulvcrona, 2014), kā arī biomasas vienādojumus Somijas izplatîtākajām koku sugām (Repola, 2008, 2009). Papildus tam Repola $(2008,2009)$ savos pētījumos secināja, ka arī augstuma transformācijas lietošana $\mathrm{H} /(\mathrm{H}+m)$ atsevišķłos gadījumos uzlabo vienādojuma precizitāti, aprēķinot biomasu noteiktām koka frakcijām.

Veicot vienādojumu logaritmisko transformāciju, jārēksinās ar papildus novirzi jeb kḷūdu, kura rodas, transformējot iegūtos rezultātus atpakal aritmētiskajās vienībās (Hunziker 
et al., 2014; Jenkins et al., 2003; Snowdon, 1991; Zianis et al., 2005). Kḷūda, kura radusies inversās transformācijas rezultātā, visbiežāk tiek koriḡèta ar dažādiem korekcijas koeficientiem, kurus pievieno linearizētajam vienādojumam pirms atpakal̦ transformēšanas. Literatūrā ir minēti dažādi pieņēmumi, aprēksinot šos korekcijas koeficientus. Ja atkarīgās pazīmes vidējās vērtības dispersija vai standartnovirze ir liela, tad tiek ieteikta izteiksme (2.8) (Marklund, 1987; Repola, 2008, 2009; Snowdon, 1991).

$$
k=\frac{\sum_{i=1}^{n} Y_{i}}{\sum_{i=1}^{n} e^{\ln \widehat{Y}_{i}}}
$$

kur:

$k$ - korekcijas koeficients;

$n$ - novērojumu skaits;

$Y_{i}$ - novērotās vērtības;

$\hat{Y}_{i}$ - aprēksinātās vērtības.

Tā kā logaritmiski transformētie vienādojumi prasa atkārtotu to pārveidošanu, reālo biomasas vērtību iegūšanai izmanto izteiksmi (2.9).

$$
\hat{Y}_{i}=k \times \exp \left(\ln \hat{Y}_{i}\right)
$$

kur:

$k$ - korekcijas koeficients;

$\hat{Y}$ - aprēķinātā biomasa kokam $i$.

Izstrādāto regresijas vienādojumu novērtēšana veikta ar determinācijas koeficientu $\left(\mathrm{R}^{2}\right)$, vidējās vērtības vidējo kvadrātisko kḷūdu (RMSE) un vidējo absolūto kḷūdu (MAPE) palīdzību, kuras aprēķinātas pēc izteiksmēm (2.10), (2.11) un (2.12).

$$
\begin{gathered}
R^{2}=1-\frac{\sum_{i=1}^{n}\left(Y_{i}-\hat{Y}_{i}\right)^{2}}{\sum_{i=1}^{n}\left(Y_{i}-\bar{Y}\right)^{2}} \\
R M S E=\sqrt{\frac{\sum_{i=1}^{n}\left(Y_{i}-\hat{Y}_{i}\right)^{2}}{n}} \\
M A P E=\frac{100}{n} \sum_{i=1}^{n} \frac{\left|Y_{i}-\hat{Y}_{i}\right|}{Y_{i}}
\end{gathered}
$$

kur:

$R^{2}$ - determinācijas koeficients;

$R M S E$ - vidējā kvadrātiskā kḷūda, kg;

MAPE - vidējā absolūtā kḷūda, \%;

$Y_{i}$ - novērotā biomasa kokam $i, \mathrm{~kg}$;

$\hat{Y}_{i}$ - aprēksinātā biomasa kokam $i, \mathrm{~kg}$;

$\bar{Y}$ - paraugkopas vidējā novērotā biomasa, kg;

$n$ - novērojumu skaits. 
MAPE vienādojumos raksturo kḷūdas procentuālo novirzi no vidējās vērtības. $R^{2}$ norāda, kāda atkarīgās pazīmes variācijas dạ̧a tieši atkarīga no faktoriālo pazīmju (argumentu) variācijas, bet RMSE atspoguḷo regresijas vienādojuma atlikumu vidējo izkliedi ap vidējo vērtību. Palielinoties $\mathrm{R}^{2}$, RMSE samazinās. Abu iepriekšminēto statistisko rādītāju izmantošana, salīdzinot regresijas vienādojumu prognozēšanas precizitāti, nav nepieciešama, jo abi rādītāji būtībā atspoguḷo vienu un to pašu, tikai pretējos virzienos (Sileshi, 2014). Tāpēc mūsu pētījumā, no abiem iepriekšminētajiem rādītājiem, vienādojumi savā starpā salīdzināti tikai pēc $\mathrm{R}^{2}$, bet RMSE lietots novērtējot vienādojumus.

Lai aprēķinātu varbūtību, ar kādu izvēlētais regresijas vienādojums ir pareizs un izvērtētu, kurš no vienādojumiem ir labāks, izmantots korig̣ētais Akaike informācijas kritērijs (AICc), kas aprēķināts pēc izteiksmes (2.13). Informācijas kritēriji ir noderīgi līdzekḷi modeļu salīdzināšanai un klasificēšanai no vislabākā uz sliktāko (Burnham \& Anderson, 2002) un tiek plaši izmantoti biologiijā un citās zinātnēs (Akaike, 1974). Sastādot vienādojumu, ir svarīgi atrast līdzsvaru starp aproksimācijas līknes precizitāti un prognozēšanas izteiksmes sarežğîtîbu. Šo problēmu risina ar informācijas kritēriju palīdzību, kur statistika iekḷauj "sodu" par nepietiekamu pielāgošanu un pārmērīgi lielu regresijas koeficientu skaitu. AICc ir tas pats AIC, bet ar augstāku jutīgumu pret papildus parametriem. AICc kritērijs tiek izmantots gadījumos, kad novērojumu skaits ir mazs, kā tas šajā pētījumā ir atsevišksu koku calma/sakṇu biomasas datiem. Motulsky \& Arthur (2003) rekomendē vienmēr lietot AICc, jo tas konvergèe uz AIC, kad novērojumu skaits kḷūst pietiekoši liels. Sileshi (2014) apgalvo, ka AICc vērtības ir labāk interpretēt, ja tās ir attiecinātas viena pret otru, norādot uz varbūtību (anglu val. Akaike's weights), ar kādu konkrētais vienādojums ir labāks.

$$
A I C c=A I C+\frac{2 p(p+1)}{n-p-1}
$$

kur:

$A I C c$ - koriḡètais Akaike informācijas kritērijs;

$A I C$ - nosacītais Akaike informācijas kritērijs ("cAIC4" pakotne datorprogrammā R);

$p$ - parametru skaits statistiskajā modelī;

$n$ - novērojumu skaits.

Katra regresijas vienādojuma koeficientu ticamība novērtēta ar relatīivo standartkḷūdu (PRSE) kas aprēķināta pēc (2.14) izteiksmes (Picard et al., 2015; Sileshi, 2014). Balstoties uz pieejamo informāciju literatūrā, pieṇemts, ka izstrādātais vienādojums tiks noraidīts, ja viena vai vairāku regresijas koeficientu PRSE vērtības būs lielākas par 30\%. Ja argumentu $(\mathrm{H}, \ln \mathrm{H})$ izslēgšana no (2.7) izteiksmes, pozitīvi ietekmēja AICc (vērtība samazinājās), vai kādam no regresijas koeficientiem PRSE bija lielāka par 30\%, minētie vienādojuma mainīgie no izteiksmes tika izslēgti un palikušo koeficientu vērtības tika pārrēķinātas.

$$
P R S E=100 \frac{\text { regresijas koeficienta standart } k l \underline{\mathrm{u}} \mathrm{da}}{\text { regresijas koeficients }}
$$

Lai izvairītos no sistemātiskām kḷūdām, katrs izstrādātais vienādojums analizēts arī ar atlikumu izkliedes diagrammu palīdzību. Relatīvā starpība starp izmērīto un aprēķināto biomasu tika attiecināta pret logaritmiski transformētām prognozētajām biomasas vērtībām. Lai atklātu sistemātiskas kḷūdas atlikumu izkliedes diagrammā, izmantota Cleveland (1979) aprakstītā slīdošā vidējā procedūra (anglu val. locally weighted scatterplot smoothing jeb LOWESS), kas iebūvēta datorprogrammā CurveExpert Professional 2.2. Lai izstrādātais vienādojums būtu izmantojams prognozēšanā, tā atlikumu izkliedes diagrammās izvilktajai 
līnijai nedrīkst parādīties būtiskas novirzes no vidējās vērtības, kā arī punktiem ir jābūt nejauši izkārtotiem. Prognozētās biomasas vērtības atlikumu izkliedes diagrammās tiek transformētas, lai vienlīdz labi varētu atklāt sistemātisku novirzi gan lieliem, gan arī maziem kokiem. 


\section{REZULTĀTI UN DISKUSIJA}

\subsection{Blīvuma izmaiņas koku stumbros}

Reducētais blīvums ir svarīgs, lai aprēķinātu biomasas daudzumu koka stumbrā un atspogulotu tā izmaiņas. Stumbra blīvuma izmaiņas garenvirzienā (no celma uz galotni) un šķērsgriezumā (no serdes uz mizu) sniedz priekšstatu par to, kā dažādas blīvuma paraugu ievākšanas metodes var ietekmēt stumbra biomasas un līdz ar to - kopējos oglekḷa uzkrājuma aprēķinus. Pētījumā lietotā stumbra koksnes reducētā blīvuma noteikšanas metodika ļauj salīdzināt mūsu datus ar līdzīgos pētījumos iegūtajiem. Starp dažādiem pētījumiem salīdzinot un analizējot koksnes blīvuma izmainas un vidējos rādītājus, iespējams gūt apstiprinājumu korekti ievāktiem datiem. Analizējot literatūrā pieejamo informāciju secināts, ka visa stumbra vidējās blīvuma vērtības vairumam koku sugu nemaz nav pieejamas. Turpretī informācija par stumbra koksnes reducētā blīvuma izmaiņām un vidējām vērtībām ir pieejama visām mūsu pētījumā iekļautajām koku sugām. Aprēķinot visa stumbra vidējo blīvumu, atšķirīibā no stumbra koksnes blīvuma, būtu jāņem vērā arī mizas īpatsvars un tās blīvums. Daudzos pētījumos stumbra biomasas aprēķinos tiek izmantoti vidējie koksnes blīvuma rādīiāji, kas ir konceptuāli nepareizi. Iepriekšminētā situācija varētu būt izveidojusies tāpēc, ka zinātniskajā literatūrā detalizēta informācija par vidējo mizas reducēto blīvumu un blīvuma izmain̄ām stumbra garenvirzienā praktiski nav atspoguḷota.

Pētījumā stumbra mizas īpatsvars uzrādīja ievērojamas atšķirības ne tikai starp pētītajām koku sugām bet arī katras sugas ietvaros. Mizas īpatsvars no kopējā stumbra tilpuma priedei ir robežās no 5.5-34.5\%, eglei 6.6-28.3\%, bērzam 7.9-21.5\% un apsei 7.023.6\%. Visām pētītajām koku sugām mazu dimensiju kokiem mizas īpatsvars stumbrā ir ievērojami lielāks nekā pieaugušiem kokiem (3.1. tabula). Pie vidējā krūšaugstuma caurmēra $5 \mathrm{~cm}$, mizas īpatsvars starp sugām variē robežās no $16.7-26.9 \%$, bet, vidējam caurmēram pieaugot līdz $30 \mathrm{~cm}$, mizas īpatsvars samazinās vairāk kā divas reizes un ir robežās no $8.2-$ 10.4\%. Tas liecina par to, ka būtisku koksnes un mizas blīvuma atšķirību gadījumā, lielāka sistemātiska kḷūda veidosies jaunaudžu stumbra biomasas aprēķinos. Latvijā mizas biezumu un tās īpatsvaru dažādu koku sugu apaļos kokmateriālos atspogul̦ojis Līpiņš un Liepa (2007). Autoru aprēķinātie vidējais mizas īpatsvara rādītāji priedei (6-15\%), bērzam (12-15\%), eglei (10\%) un apsei (10\%) ir līdzvērtīgi šajā pētījumā iegūtajiem rādītājiem un izmantojami koku ar krūšaugstuma diametru virs $10 \mathrm{~cm}$ aprakstīšanai, kas arī atbilst autoru ievāktajam empīriskajam materiālam.

3.1. tabula

Vidējās mizas īpatsvara vērtības no kopējā stumbra tilpuma \pm standartkḷūda atkarībā no koka krūšaugstuma caurmēra

\begin{tabular}{ccccc}
\hline $\mathrm{D}, \mathrm{cm}$ & Priede & Egle & Bērzs & Apse \\
\hline 5 & $26.9 \pm 1.3$ & $20.9 \pm 0.9$ & $16.7 \pm 0.4$ & $17.9 \pm 0.6$ \\
10 & $18.9 \pm 0.7$ & $14.9 \pm 0.9$ & $12.1 \pm 0.6$ & $12.3 \pm 0.4$ \\
15 & $10.9 \pm 0.7$ & $11.2 \pm 0.5$ & $11.1 \pm 0.4$ & $11.0 \pm 0.3$ \\
20 & $9.8 \pm 0.5$ & $9.6 \pm 0.3$ & $10.9 \pm 0.3$ & $10.0 \pm 0.5$ \\
25 & $8.9 \pm 0.5$ & $8.5 \pm 0.3$ & $10.5 \pm 0.6$ & $10.1 \pm 0.6$ \\
30 & $7.7 \pm 0.4$ & $8.2 \pm 0.3$ & $10.4 \pm 0.4$ & $9.1 \pm 0.5$ \\
\hline
\end{tabular}

Mizas īpatsvars koka stumbrā lielāks ir celma, bet jo īpaši galotnes daļā (3.1. attēls). Mizas īpatsvara izmaiņas stumbra garenvirzienā ir atkarīgas no mizas biezuma un stumbra diametra kombinētas ietekmes. Tuvojoties koka galotnei, stumbra šķērsgriezuma caurmērs 
samazinās straujāk. Turpretī miza galotnes dạ̧ā kḷūst tikai nedaudz plānāka salīdzinot ar stumbra vidusdaļu, tāpēc arī mizas īpatsvars strauji palielinās. Piemēram, no egles stumbra tievgal̦a sagatavotiem apal̦ajiem kokmateriāliem, mizas procentuālais daudzums ir par apmēram 7\% lielāks nekā apaļkokiem no stumbra vidusdaļas (Sarmulis et al., 2005). Mazākais mizas īpatsvars katrai koku sugai tiek sasniegts atšķirīgos stumbra relatīvajos augstumos. Priedei mazākais mizas īpatsvars ir stumbra vidusdaļā (50\% relatīvais augstums), kamēr eglei, bērzam un apsei zemākais mizas īpatsvars ir stumbra lejasdaļā (apmēram 20$30 \%$ relatīvais augstums). Līdzīgi rezultāti ir konstatēti arī Somijā, kur eglei vismazākais mizas īpatsvars norādīts pie 20\% relatīvā augstuma (Laasasenaho, Melkas, \& Aldén, 2005). Analizējot priedes un egles mizas biezuma izmaiņas vienāda diametra kokiem, novērots, ka virs 20\% relatīvā augstuma priedes miza kḷūst plānāka nekā egles miza (Drēksa, Līpiṇš, \& Sarmulis, 2003). Turpretī stumbra lejasdalāā, priedei miza ir biezāka nekā eglei.
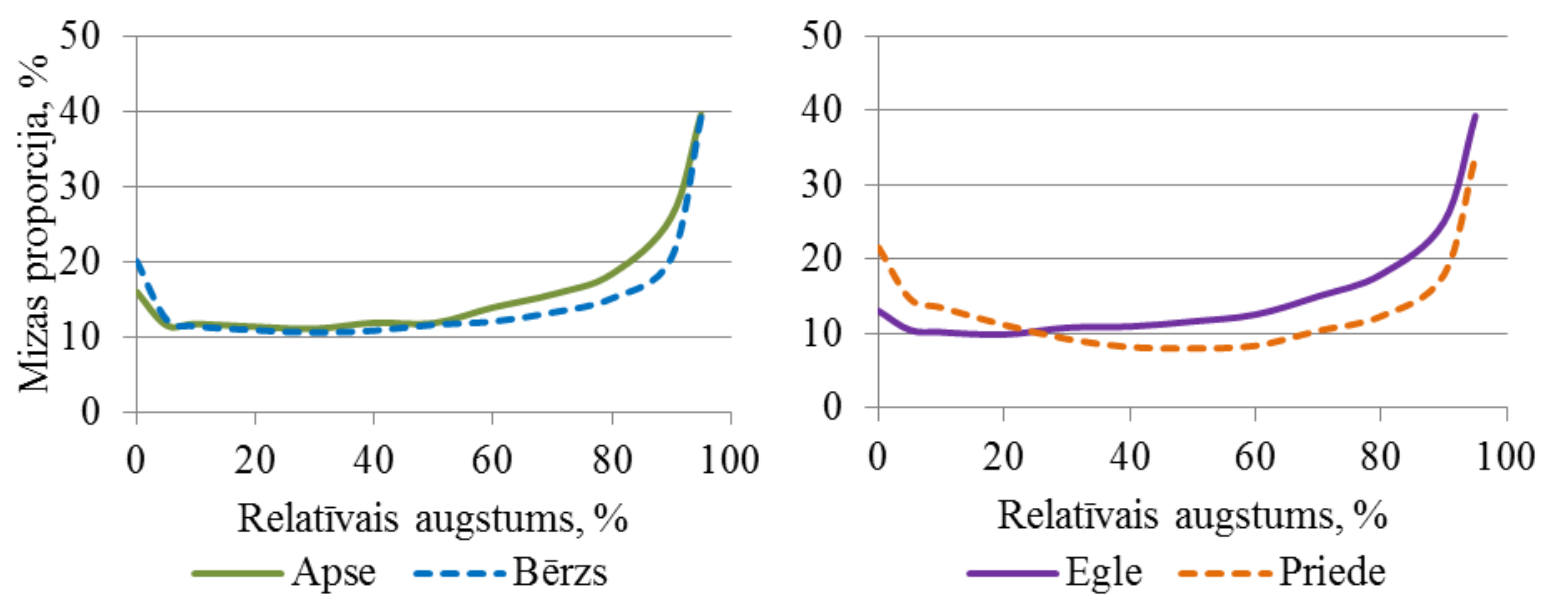

\section{1. att. Mizas īpatsvars stumbra šksēersgriezumā atkarībā no relatīvā augstuma}

Lielu daļu no mizas apjoma izmaiņām izskaidro koka krūšaugstuma caurmēra, augstuma vai stumbra tilpuma variācija (Liepiņš \& Liepiņš, 2015). Tā kā koka krūšaugstuma caurmērs ir visvieglāk un visprecīzāk izmērāmā koka pazīme, tad pētījumā noskaidrots, ka priedes, egles, bērza un apses caurmērs izskaidro, attiecīgi 85\%, 86\%, 51\% un $79 \%$ no mizas īpatsvara izmaiņām un ir vispiemērotākā pazīme tā prognozēšanai. Vislielākā nenoteiktība, prognozējot vidējo mizas daudzumu koka stumbrā, ir bērzam, uz ko norāda arī zemāks determinācijas koeficients. Daudz izteiktāku datu izkliedi, kas ievērojami pārsniedz priedes un egles datu izkliedi, ir konstatējis Liepa (2011), aprēķinot bērza mizas tilpumus koka stumbrā. Autors to skaidro kā divu bērza sugu datu sapludināšanu, ignorējot šo sugu specifiku. Dal̄eji bērza mizas īpatsvara aprēķinu nenoteiktība varētu būt skaidrojama ar kreves mizas veidošanos stumbra lejasdạ̧ā, kuras biezums vienādu diametru kokiem var būt ļoti atšķirīgs dažādām koku populācijām un pat vienas kokaudzes ietvaros. Lai gan kreves miza bērzam parasti nesniedzas augstāk par $3 \mathrm{~m}$ un iekḷaujas pirmajā resgaḷa sortimentā (Līpiņš \& Liepa, 2007), tomēr tā atstāj lielu ietekmi uz aprēķinu nenoteiktību.

Klimatisko zonu un meža tipa ietekme uz eģ̣u mizas īpatsvaru koka stumbrā ir pētīta Somijā (Laasasenaho et al., 2005). Pētījums apstiprināja, ka veǵetācijas perioda garums ir būtisks faktors, kas ietekmē mizas biezumu un līdz ar to arī mizas īpatsvaru koka stumbrā. Somijas ziemel̦u daļā augošajām eglēm miza ir biezāka, bet meža tipa ietekme uz mizas biezumu pētījumā netika apstiprināta. Promocijas darba ietvaros netika konstatêtas būtiskas mizas îpatsvara atšķirības starp meža nogabaliem valsts ziemeļu-dienvidu, kā arī austrumurietumu virzienā, kas skaidrojams ar relatīvi nelielo Latvijas teritoriju un meža nogabalu ǵeogrāfisko izkliedi. Visi atlasītie meža nogabali atradās starp 56.-58. paralēli un 21.-27. meridiānu (2.1. attēls). Koku augšanas reǵiona ietekme uz mizas biezumu priedei, eglei, 
bērzam un apsei nav konstatēta arī iepriekš veiktajos pētījumos Latvijā (Līpiņš \& Liepa, 2007). Tas apliecina, ka pētîjumā aprēķinātie vidējie mizas īpatsvara rādītāji ir attiecināmi uz visu Latvijas teritoriju.

Pētījumā apstiprinājās, ka priedes, egles, bērza un apses stumbra vidējais mizas blīvums statistiski būtiski ( $p<0.001)$ atšķiras no vidējā koksnes blīvuma (3.2. tabula). Minētais fakts apstiprina to, ka koksnes reducēto blīvuma vērtību izmantošana visa koku stumbra biomasas aprēķināšanai rada sistemātisku kḷūuu, vidēji palielinot stumbra biomasu priedei par $4.5 \%$ un eglei par $2.5 \%$, bet bērzam un apsei samazinot kopējo stumbra biomasu attiecīgi par $2.4 \%$ un 1.5\%. Zīmīgi, ka pētītajām skujkoku sugām vidējais koksnes blīvums ir lielāks nekā mizai pretēji lapkoku sugām, kurām miza ir blīvāka par koksni. Priedei koksnes un mizas reducêtā blīvuma starpība $\left(137 \mathrm{~kg} \mathrm{~m}^{-3}\right)$ ir ievērojami lielāka kā pārējām koku sugām (apsei - $52 \mathrm{~kg} \mathrm{~m}^{-3}$, bērzam $-80 \mathrm{~kg} \mathrm{~m}^{-3}$ un eglei $-82 \mathrm{~kg} \mathrm{~m}^{-3}$ ). Tas ir skaidrojams ar krasākām koksnes blīvuma izmaiņām priedes stumbru garenvirzienā, salīdzinājumā ar pārējām koku sugām. Līdzīgi secinājumi par mizas un koksnes blīvuma atšķirību ietekmi uz biomasas aprēķiniem iegūti arī Somijā (Hakkila, 1979), kur, raksturojot vidējo priedes stumbra biomasu ar mizu, tiek rekomendēts koriḡèt jeb samazināt iegūtās biomasas vērtības par $2 \%$, bet bērzam palielināt stumbra biomasu par $0.5 \%$, tādā veidā netieši norādot uz identiskām mizas un koksnes blīvuma atšksirībām. Līdzīgi priedei, arī egles mizas blīvums tiek ziņots mazāks nekā koksnei (Hakkila, 1989), kā arī konstatēts, ka mizas blīvums nepārtraukti samazinās virzienā uz galotni. Erickson (1972) pētījis dažādu Ziemel̦amerikas koku sugu mizas un koksnes reducētā blīvuma atšksirības šķeldas paraugos, secinot, ka apsei miza ir daudz blīvāka par koksni, bet visām pētītajām skujkoku sugām mizas blīvums izrādījās mazāks nekā koksnei.

3.2. tabula

Koku sugu svērtās vidējās reducētā blīvuma vērtības \pm standartnovirze

\begin{tabular}{|c|c|c|c|}
\hline Koku suga & $\begin{array}{l}\text { Visa stumbra blīvums, } \\
\mathrm{kg} \mathrm{m}^{-3}\end{array}$ & $\begin{array}{l}\text { Stumbra koksnes } \\
\text { blīvums, } \mathrm{kg} \mathrm{m}^{-3}\end{array}$ & $\begin{array}{c}\text { Stumbra mizas } \\
\text { blīvums, } \mathrm{kg} \mathrm{m}^{-3}\end{array}$ \\
\hline Priede & $380 \pm 48$ & $397 \pm 49$ & $260 \pm 24$ \\
\hline Egle & $368 \pm 35$ & $378 \pm 36$ & $295 \pm 27$ \\
\hline Bērzs & $481 \pm 38$ & $470 \pm 46$ & $551 \pm 36$ \\
\hline Apse & $399 \pm 30$ & $393 \pm 29$ & $446 \pm 39$ \\
\hline
\end{tabular}

Analizējot mizas un koksnes vidējo blīvuma vērtību starpību stumbra garenvirzienā, noskaidrots, ka, izņemot apsi, pārējām pētītajām koku sugām blīvuma atšķirības saglabājas būtiskas $(p<0.05)$ visa stumbra garumā (3.2. attēls). Tikai apses stumbru galotnes daḷā (70$100 \%$ relatīvais koku augstums) netika konstatētas būtiskas mizas un koksnes blīvuma atšķirības. Tas izskaidrojams ar to, ka mizas un koksnes blīvuma izmaiņas stumbra garenvirzienā neseko vienām un tām pašām tendencēm, kā arī blīvuma izmaiṇu amplitūda apses mizai ir nedaudz lielāka, kā pārējām pētījumā iekḷautajām koku sugām. Apses mizas blīvums stumbra galotnes virzienā samazinās; stumbra lejasgalā strauji, bet galotnes daļā tikai nedaudz. Turpretī koksnes blīvums samazinās tikai līdz $30-40 \%$ relatīvajam koka augstumam, bet pēc tam, virzienā uz galotni, pakāpeniski pieaug. Arī citām lapkoku un skujkoku sugām mizas blīvuma izmaiņas stumbra garenvirzienā nesakrīt ar koksnes blīvuma izmain̄ām. Atseviškām koku sugām mizas blīvuma starpība starp celmu un galotni var sasniegt $100 \mathrm{~kg} \mathrm{~m}^{-3}$ (Hakkila, 1989). Piemēram, priedei mizas blīvums virzienā uz galotni samazinās, bet pēc tam galotnes daļā nedaudz pieaug. Turpretī bērzam mizas blīvums virzienā uz galotni pieaug, bet galotnes daļā nedaudz samazinās. Eglei mizas blīvums stumbra garenvirzienā samazinās; līdz 10\% relatīvajam augstumam samazināšanās notiek ļoti strauji, bet pārējā stumbra dạ̧ā samazinājums ir neliels. 


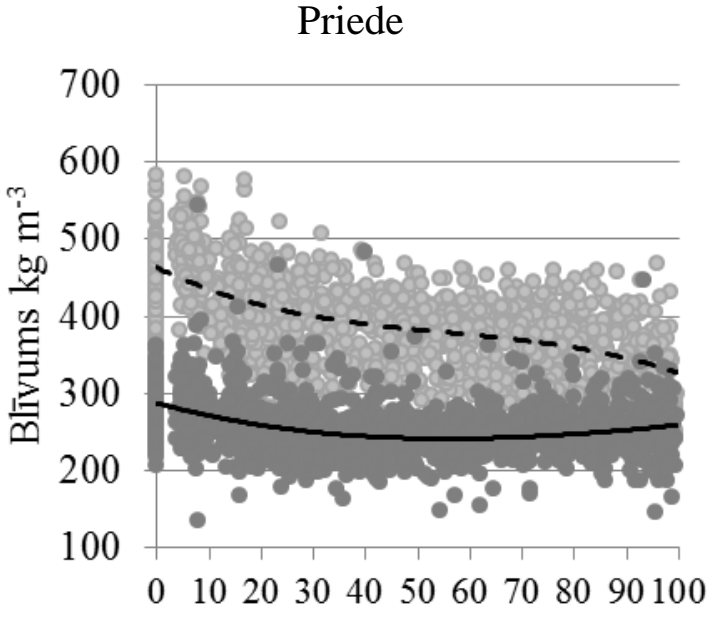

Bērzs

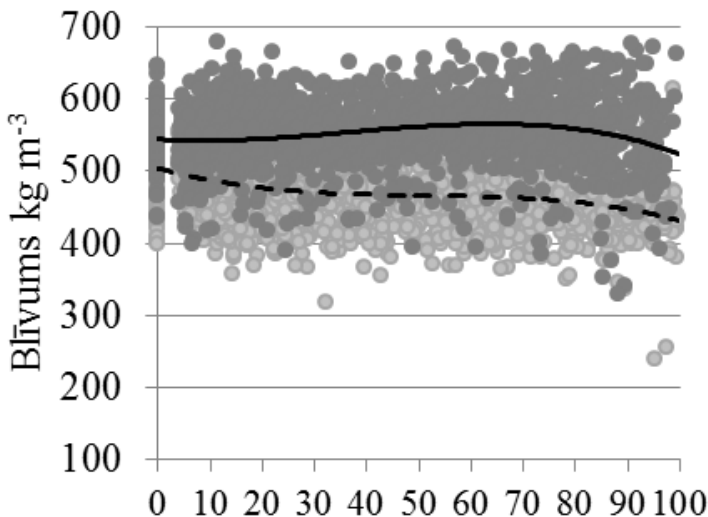

Relatīvais augstums, \%
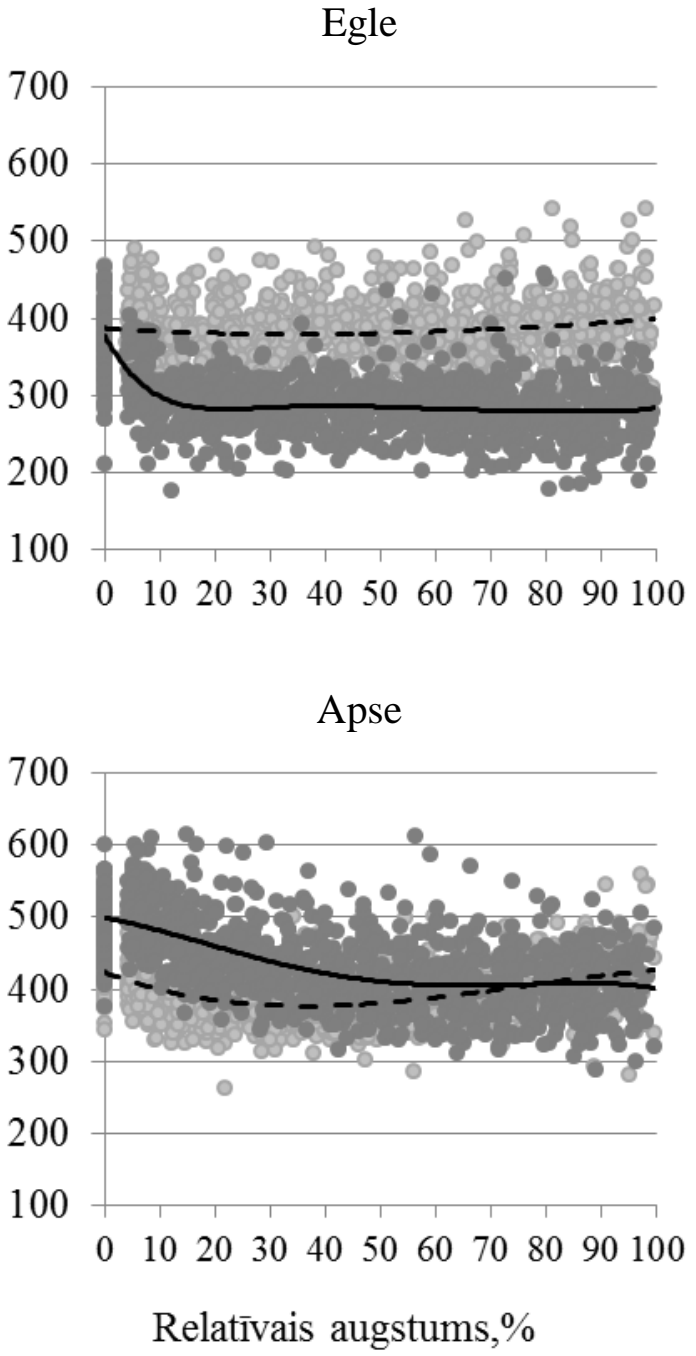

\section{2. att. Vidējā stumbra koksnes (punktētā līnija) un stumbra mizas (nepārtrauktā līnija) reducētā blīvuma izmaiṇas stumbra garenvirzienā}

Dibdiakova un Vadla (2012) konstatējuši būtiskas atšķirības $(p<0.05)$ Sitkas egles mizas blīvuma izmain̄ās stumbra garenvirzienā un novērojuši, ka tikai celma dạ̦ā mizas blīvums pārsniedz koksnes blīvumu. Millers un Magaznieks (2012), analizējot priedes koksnes un mizas blīvuma izmaiņas atkarībā no koka vecuma, konstatējuši būtiskas atškirīības tikai koksnes blīvumā. Iepriekšminētajā pētījumā salīdzinot $37-70$ gadus un $70-146$ gadus vecas priedes, to vidējais mizas blīvums bija praktiski nemainīgs. Analizējot mūsu pētījuma datus ar lineārās regresijas analīzi, konstatēts, ka koka vecums būtiski neietekmē mizas vidējo blīvumu lapkoku sugām, turpretī priedei un eglei vecuma ietekme izrādījās būtiska $(p<0.001)$. Mūsu un iepriekšminētā pētījuma atšksirīgie rezultāti izskaidrojami ar to, ka Millers un Magaznieks (2012) nebija iekḷāvuši salīdzināšanai priedes jaunākas par 37 gadiem. Pētījumā konstatēts, ka pirmo divu vecumklašu skujkokiem vidējais mizas reducētais blīvums ir par 30-50 $\mathrm{kg} \mathrm{m}^{-3}$ mazāks nekā ciršanas vecumu sasniegušiem kokiem.

Vidējais svērtais priedes, egles, bērza un apses stumbra koksnes reducētais blīvums iegūts mūsu pētījumā ir attiecīgi 397, 378, 470 un $393 \mathrm{~kg} \mathrm{~m}^{-3}$ (3.2. tabula). Kā redzams 3.3. attēls, vidējais stumbra koksnes blīvums priedei, eglei un bērzam mainās atkarībā no koka dimensijām. Tāpēc, salīdzinot blīvuma datus ar citos pētījumos iegūtajiem, ir jāṇem vērā arī izmantoto paraugkoku dimensijas. Mūsu rezultāti apliecina, ka IPCC vadlīniju (Eggleston et al., 2006) dotās blīvuma vērtības (1.2. tabula) priedes, egles un bērza biomasas aprēķināšanai noved pie $C$ apjoma pārvērtēšanas jaunaudzēs, jo blīvuma vērtības atbilst tikai kokiem ar 
krūšaugstuma caurmēru lielāku par $20-30 \mathrm{~cm}$, jeb pieaugušiem kokiem. Turpretī apses biomasas aprēḳiniem IPCC vadlīniju rekomendētais blīvums $350 \mathrm{~kg} \mathrm{~m}^{-3}$ ir ievērojami zemāks nekā mūsu pētījumā konstatētais, norādot uz ievērojamu biomasas potenciāla un $\mathrm{C}$ apjoma nenovērtēšanu Latvijas apšu mežaudzēs.
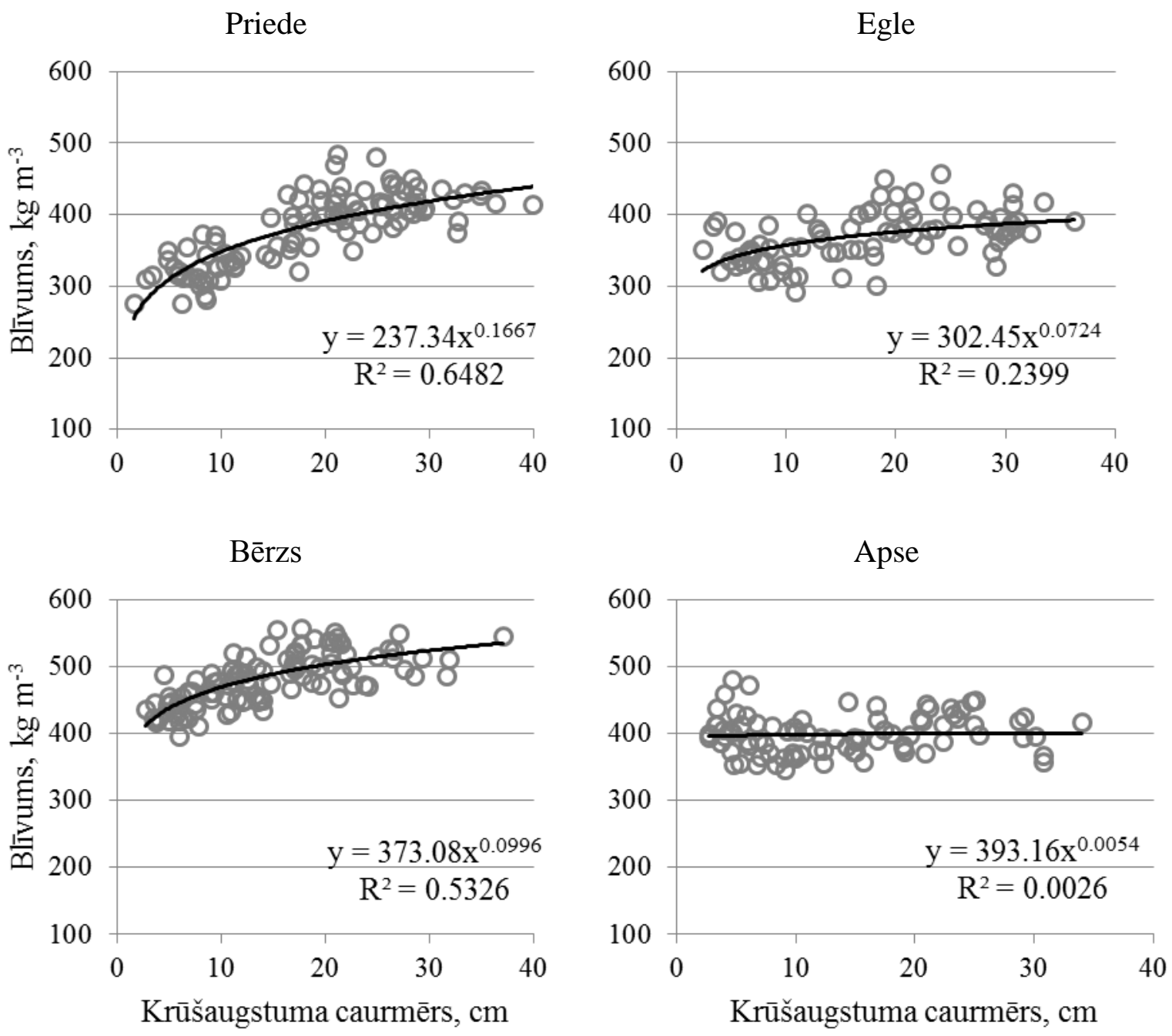

\section{3. att. Stumbra koksnes reducētā blīvuma izmaiṇas atkarībā no koka krūšaugstuma caurmēra}

Literatūrā minētās vidējās koksnes reducētā blīvuma vērtības parastajai apsei ir robežās no $376 \mathrm{~kg} \mathrm{~m}^{-3} \mathrm{li} \mathrm{dz} 403 \mathrm{~kg} \mathrm{~m}^{-3}$ (Heräjärvi \& Junkkonen, 2006; Karki, 2001; Rytter et al., 2016; Smilga, 1988). Mūsu pētījumā konstatētais vidējais apses koksnes blīvums $393 \mathrm{~kg} \mathrm{~m}^{-3}$ atbilst iepriekš norādītajām blīvuma vērtībām.

Līdzīgi kā citām koku sugām, arī apses koksnē ir lielas reducētā blīvuma atšksirības, bet atšķirībā no pārējām apskatītajām koku sugām, blīvuma atšķirīibas apsei izskaidrot ir sarežğìtāk. Iespējams, ka tās nosaka kompleksa vairāku pazīmju ietekme. Pētījumā netika konstatēta statistiski būtiska $(p>0.05)$ apses vidējā stumbra koksnes blīvuma un koka krūšaugstuma caurmēra, koka augstuma, kokaudzes šķērslaukuma, kā arī kokaudzes vecuma korelācija. Tāpat pārbaudot ar dispersijas analīzi koku Krafta klases ietekmi uz vidējo stumbra blīvumu, netika konstatētas statistiski būtiskas $(p>0.05)$ atšķirīibas. No visām pētījuma ietvaros reǵistrētajām koka un kokaudzes pazīmēm, statistiski būtiska $(p=0.01)$ izrādījās koku skaita uz hektāru un apses koksnes vidējā blīvuma korelācija. Lai gan korelācijas koeficients ir neliels (-0.28), tomēr tas norāda uz to, ka mazāks blīvums ir kokiem, 
kuri auguši lielākā biezumā. Vispārzināms ir fakts, ka jaunaudzēs koku skaits ir lielāks un jauniem kokiem strauji augot, to koksnes blīvums vienmēr ir mazāks (Saranpää, 2003). Sasniedzot 15 gadu vecumu, parastajai apsei gadskārtu platums un augšanas temps ievērojami samazinās (Heräjärvi \& Junkkonen, 2006). Kopumā ir izpētīts, ka koku augšanas ātrumam ir neliela ietekme uz Populus spp. koksnes blīvumu (Zhang, 1995; Zobel \& Jett, 1995), kas izskaidro, kādēl konstatētā korelācija starp koku skaitu un apses koksnes vidējo blīvumu ir relatîvi vāja.

Rytter et al. (2013) apkopojuši koksnes reducētā blīvuma vērtības, kas publicētas Ziemel̦eiropas un Baltijas valstīs. Autori secina, ka parastās egles koksne ir salīdzinoši viegla, dažādos pētījumos blīvumam esot robežās no $310-400 \mathrm{~kg} \mathrm{~m}^{-3}$. Savukārt priedes koksne ir smagāka; atsevišksos pētījumos priedes reducētais blīvums konstatēts pat $475 \mathrm{~kg} \mathrm{~m}^{-3}$. Apses blīvums, analizējot dažādus pētījumus, novērots robežās no $350-400 \mathrm{~kg} \mathrm{~m}^{-3}$, bet bērza koksne ir smagāka nekā vairumam Eiropā sastopamo skujkoku sugām, reducētajam blīvumam esot robežās no $430-520 \mathrm{~kg} \mathrm{~m}^{-3}$ (Rytter et al., 2013). Latvijā konstatēts, ka bērzu plantācijās lauksaimniecības augsnēs stumbru koksnes vidējais blīvums ir $455 \mathrm{~kg} \mathrm{~m}^{-3}$ (Liepins \& Rieksts-Riekstins, 2013). N̦emot vērā ātrāku koku augšanu un īsāku koku rotācijas periodu, tas ir nedaudz mazāks nekā mežaudzēs augušai koksnei. Somijā konstatēts, ka āra bērzs un purva bērza koksnes blīvums neatšķiras, ja vien to augšanas temps ir vienāds (Repola, 2006). Praksē gan parasti puva bērza augšanas temps ir mazāks, tāpēc jārēķinās, ka bērza vidējais koksnes blīvums kūdras augsnēs varētu būt lielāks, jo šādās augsnēs vairāk dominē tieši purva bērzs. Aprēķinātais purva bērza vidējais koksnes blīvums Igaunijā ir $532 \mathrm{~kg} \mathrm{~m}^{-3}$ un tas būtiski lielāks ir vecās mežaudzēs (Uri et al., 2017).

Citās valstīs kā Austrijā, Čehijāâ, Beḷgijāâ, Vācijā, Francijā un Rumānijāan, pārrēḳinot stumbra tilpumu biomasas vienībās, priedei lietotās blīvuma vērības ir robežās no 360 līdz $480 \mathrm{~kg} \mathrm{~m}^{-3}$, eglei no 360 līdz $438 \mathrm{~kg} \mathrm{~m}^{-3}$, bet bērzam no 490 līdz $551 \mathrm{~kg} \mathrm{~m}^{-3}$ (Neumann et al., 2016). Eiropā atspoguloto vidējo blīvuma vērtību amplitūda ir ļoti plaša un ne vienmēr ir iespējams pārliecināties par ievākto blīvuma paraugu mērķi, izmantotajām metodēm un kvalitāti, kas ir svarīgi, salīdzinot iegūtos rezultātus. Daudz detalizētāka koksnes blīvumu ietekmējošo faktoru analīze un vidējo vērtību atspogulsojums ir veikts Somijā (Hakkila, 1979), kur aprēķinātās stumbra koksnes reducētā blīvuma vidējās vērtības parastajai priedei ir $403 \mathrm{~kg} \mathrm{~m}^{-3}$, parastajai eglei $-380 \mathrm{~kg} \mathrm{~m}^{-3}$ un bērzam $-483 \mathrm{~kg} \mathrm{~m}^{-3}$.Š̄is vērtības ir tikai nedaudz lielākas par mūsu noteiktajām. Pētījumā konstatēts, ka iepriekšminētajām koku sugām, pieaugušiem kokiem blīvums ir par 11\% lielāks nekā jauniem kokiem, kā arī kūdras augsnēs augušām eglēm un priedēm blīvums ir lielāks, kas izskaidrojams ar zemāku koku augšanas tempu.

Jaunākā Somijā veiktā pētījumā (Repola, 2006) ir iegūti līdzīgi vidējā blīvuma rezultāti. Pētījumā analizēti 585 priedes, 585 egles un 195 bērzu paraugkoki un katrai koku sugai izstrādāti vienādojumi blīvuma prognozēšanai jebkurā koka augstumā, kā arī aprēķinātas vidējās koksnes blīvuma vērtības priedei $-412 \mathrm{~kg} \mathrm{~m}^{-3}$, eglei $-385 \mathrm{~kg} \mathrm{~m}^{-3}$ un bērzam $475 \mathrm{~kg} \mathrm{~m}^{-3}$. Arī šajā pētījumā iegūtās vidējās blīvuma vērtības ir tikai nedaudz lielākas (par 4-15 $\mathrm{kg} \mathrm{m}^{-3}$ atkarībā no koku sugas) nekā konstatēts mūsu pētījumā. Vidējā blīivuma atšķkirība varētu būt izskaidrojama ar to, ka Repola (2006) savā pētījumā pamatā analizējis kokus, kuri vecāki par 20 gadiem ar krūšaugstuma caurmēru, kas lielāks par $8 \mathrm{~cm}$. Turpretī mūsu pētījumā analizēti jaunāki un arī mazāka caurmēra koki.

Verificējot Repola (2006) izstrādātos blīvuma prognožu vienādojumus ar mūsu pētījumā ievāktajiem paraugkoku mērījumu datiem, secināts, ka priedei, eglei un bērzam blīvums tiek aprēķināts diezgan līdzịgi visā stumbra garenvirzienā (3.4. attēls). Vidējais koksnes blīvums priedei un bērzam, aprēķināts pēc vienādojumiem bija attiecīgi par $3.4 \%$ un $2.2 \%$ augstāks nekā mūsu pētījumā iegūtais vidējais blīvums. Turpretī eglei neizskaidrojamu iemeslu dẹl aprēķinātais vidējais koksnes blīvums bija par 4.3\% zemāks nekā mūsu pētījumā konstatētais un rezultējās sistemātiskā blīvuma novirzē visa stumbra garenvirzienā (Liepinš̌ \& Liepiņš, 2017). 

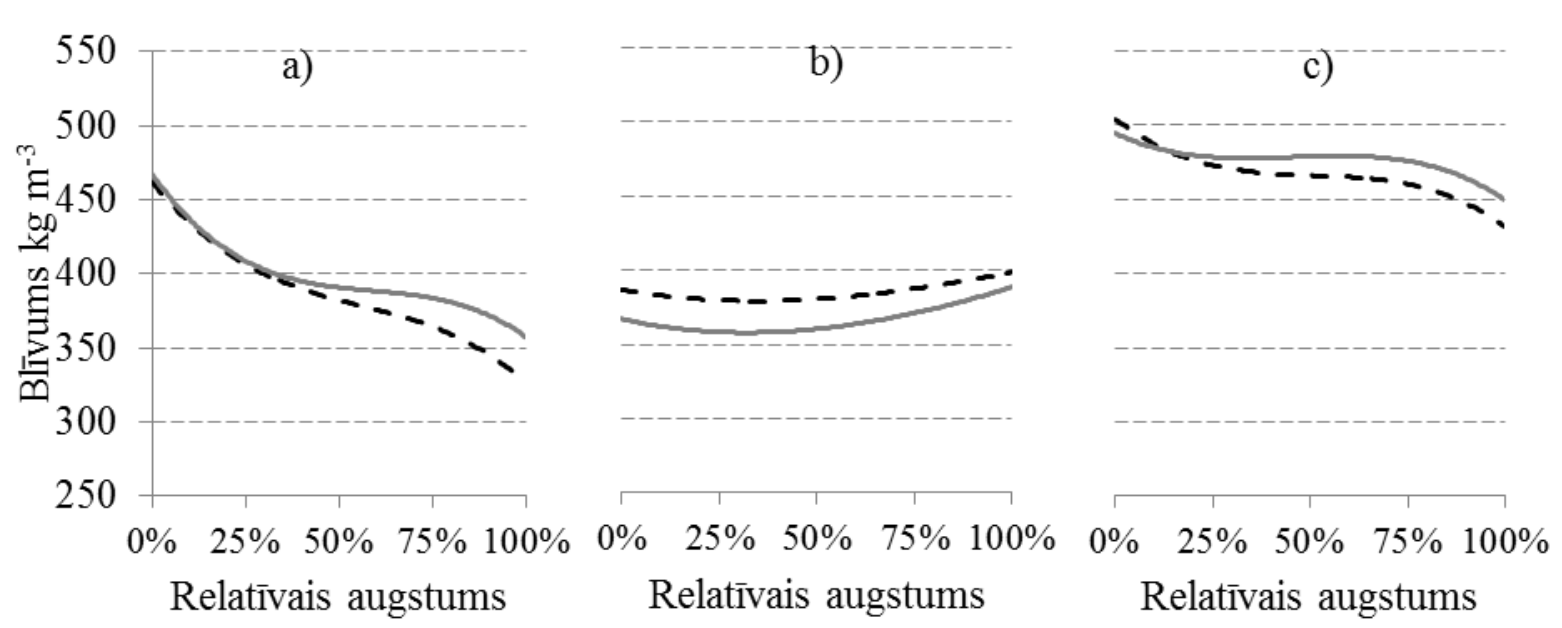

\section{4. att. Koksnes reducētais blīvums (a) priedes, (b) egles un (c) bērza stumbru garenvirzienā pēc Repola (2006) vienādojumiem (pelēkā līnija) un mūsu mērījumiem (melnā, pārtrauktā līnija)}

Blīvuma izmaiņas stumbra garenvirzienā, kā arī virzienā no serdes uz mizu ir jāṇem vērā, nosakot vidējo stumbra blīvumu. Novērots, ka stumbra vidējo blīvumu visprecīzāk raksturo blīvuma paraugs, kurš iegūts 25\% relatīvajā augstumā (Hakkila, 1979). Praksē šādā augstumā iegūt blīvuma paraugus ir dārgi un darbietilpīgi, tāpēc bieži vien augošiem kokiem tos iegūst koku krūšaugstumā. Vairākos pētījumos iegūtā informācija apliecina, ka krūšaugstumā ievāktam blīvuma paraugam vienmēr būs augstāks blīvums nekā vidēji visam stumbram, jo vispārīgi koksnes blīvumam ir tendence samazināties stumbra garenvirzienā, kā arī palielināties radiālajā virzienā no serdes uz mizu (Repola, 2006; Saranpää, 2003).

Priedei un bērzam novērota izteikta stumbra koksnes blīvuma samazināšanās virzienā uz galotni (3.2. attēls), bet radiālajā virzienā blīvumam ir tendence palielināties mizas virzienā (3.5. attēls). Palielinoties koka relatīvajam augstumam, blīvuma izmainu amplitūda stumbra šķērsgriezumā ievērojami samazinās. Piemēram, priedei $10 \%$ un $20 \%$ relatīvajā augstumā ir vislielākā blīvuma variēšana, kas stumbra šḳērsgriezumā var sasniegt pat $126 \mathrm{~kg} \mathrm{~m}^{-3}$, turpretī pie $70 \%$ un $80 \%$ relatīvā augstuma blīvuma variēšana ir gandrīz trīs reizes mazāka, nepārsniedzot $47 \mathrm{~kg} \mathrm{~m}^{-3}$. Bērzam no $0-40 \%$ relatīvajā augstumā blīvums virzienā no serdes uz mizu samazinās vidēji par $105 \mathrm{~kg} \mathrm{~m}^{-3}$, bet pie $80 \%$ relatīvā augstuma blīvums samazinās vairs tikai par $63 \mathrm{~kg} \mathrm{~m}^{-3}$. Zīmīgi, ka bērzam, neatkarīgi no stumbra relatīvā augstuma, blīvumam ir tendence samazināties virzienā no serdes uz mizu, bet priedei blīvums radiālajā virzienā palielinās līdz noteiktam caurmēram, bet pēc tam, tuvojoties mizai, nedaudz samazinās. Līdzīgus novērojumus Somijas dienvidos ir konstatējis arī Hakkila (1979) secinot, ka pēc apmēram 80 gadu sasniegšanas priedes stumbra blīvums aplievas ārējā daḷā nedaudz samazinās. 


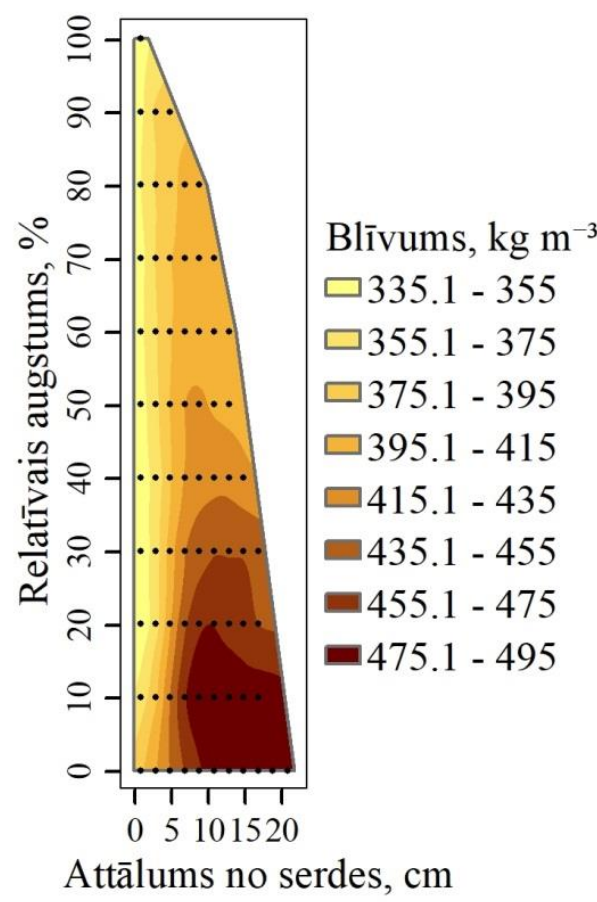

Priede

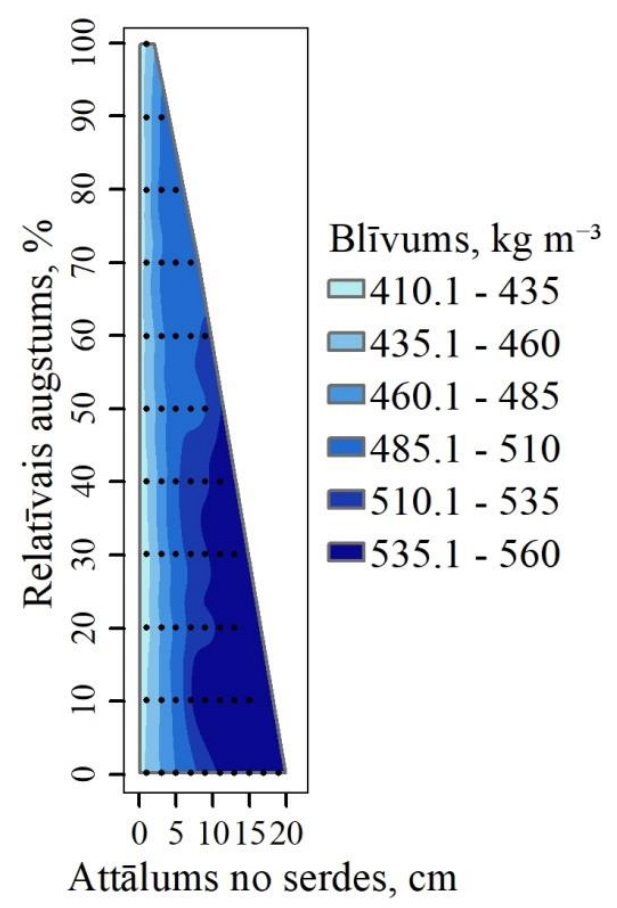

Bērzs

\section{5. att. Koksnes reducētā blīvuma izmaiṇas priedes un bērza stumbros}

Eglei un apsei blīvuma izmaiņas stumbra garenvirzienā nav tik izteiktas kā priedei un bērzam. Pieaugot koka relatīvajam augstumam, vidējais blīvums apmēram līdz stumbra vidusdaļai nedaudz samazinās vai saglabājas konstants, bet pēc tam virzienā uz galotni tas pieaug (3.2. attēls). Viszemākās stumbra šķērsgriezuma vidējās blīvuma vērtības eglei $\left(377 \mathrm{~kg} \mathrm{~m}^{-3}\right)$ un apsei $\left(381 \mathrm{~kg} \mathrm{~m}^{-3}\right)$ ir 3-6 m augstumā vai pie 20-40\% relatīvā koku augstuma, kas novērots arī citos pētījumos (Heräjärvi \& Junkkonen, 2006; Karki, 2001; Repola, 2006; Saranpää, 2003).

No citiem pêtījumiem atšķirīgas blīvuma izmaiņas stumbra garenvirzienā ir atspoguḷotas parastās egles dažādas biezības izmēǵinājumos (Johansson, 1993). Minētajā pētījumā krasās blīvuma svārstības stumbra garenvirzienā, īpaši stumbra augšējā daļā, varētu būt izskaidrojamas ar pētījumu metodoloǵiskām atšķirībām, ievācot blīvuma paraugus. Piemēram, mūsu pētījumā blīvuma paraugi ievākti ik pa $1 \mathrm{~m}$ vai $2 \mathrm{~m}$, atkarībā no koku garuma, bet minētajā pētījumā blīvuma paraugi ievākti tikai $0 \mathrm{~m}, 4 \mathrm{~m}, 7 \mathrm{~m}, 10 \mathrm{~m}, 13 \mathrm{~m}$ augstumā, nenorādot stumbra kopējo garumu, kā arī analizēta tikai viena vecuma koki. Arī citos pētījumos blīvuma paraugripas izzāgeètas vai nu no dažāda garuma koksnes sortimentu sākuma un beigu dal̦ām (Repola, 2006) vai vēl lielākos attālumos (Jyske et al., 2008; Wilhelmsson et al., 2002). Tādējādi iegūtās blīvuma vērtības starp pētîjumiem var nedaudz atšķirties, jo īpaši attiecībā uz priedi un bērzu, kur blīvums stumbra garenvirzienā samazinās l’oti strauji. Katrā ziņā, jo biežākos intervālos ņemti blīvuma paraugi, jo tie precīzāk atspoguḷo blīvuma izmaiņas stumbra garenvirzienā.

Analizējot egles un apses blīvuma izmaiņas virzienā no serdes uz mizu, secināms, ka tāpat kā pārējām pētītajām koku sugām, vismazākais blīvums ir stumbra vidusdaļā pie serdes (juvenīlai koksnei). Tāpat stumbra galotnes dạ̦ā blīvuma izmaiņu amplitūda, salīdzinot ar stumbra lejasdaḷu, ievērojami samazinās (3.6. attēls). Interesanti, ka juvenīlai koksnei nav noteiktas pārejas, kur tā sākas un beidzas, bet tās fizikālās un mehāniskās īpašības, tajā skaitā blīvums, ievērojami atšķiras no pārējās koksnes (Saranpää, 2003). 


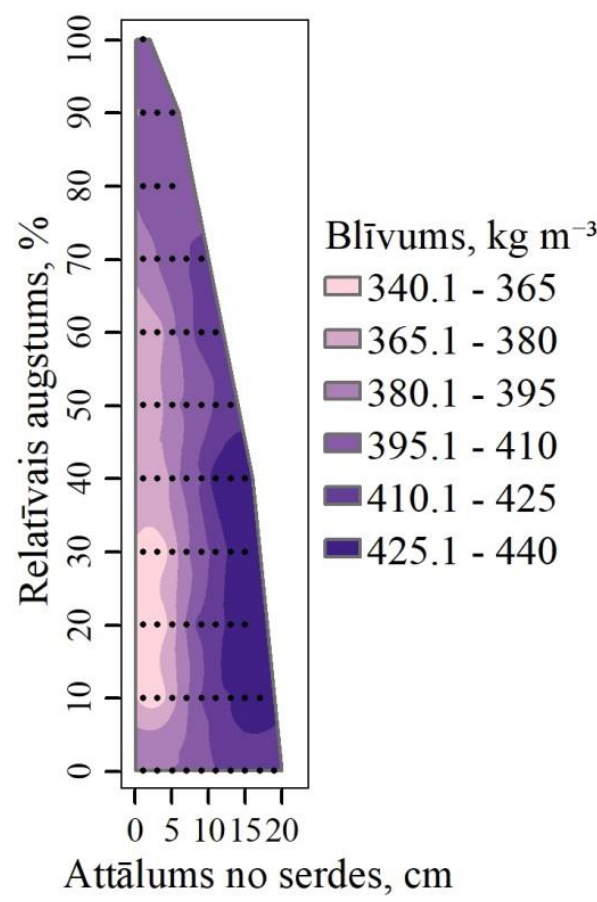

Egle

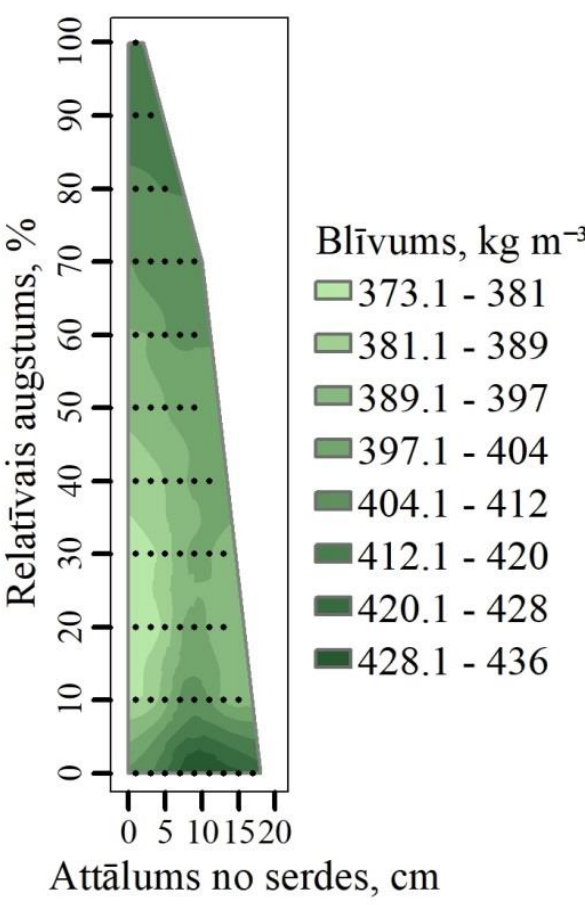

Apse

\section{6. att. Koksnes reducētā blīvuma izmaiņas egles un apses stumbros}

Egles un apses stumbros, apmēram pie $80 \%$ relatīvā augstuma, blīvums ir praktiski konstants, izmaināām radiālajā virzienā nepārsniedzot $8 \mathrm{~kg} \mathrm{~m}^{-3}$. Apsei stumbra lejasdạ̄ā, līdzīgi kā priedei, blīvums palielinās līdz noteiktam caurmēram. Savu maksimumu blīvums sasniedz apmēram $8-10 \mathrm{~cm}$ no serdes, pēc tam nedaudz samazinoties. Tā ir nozīmīga atziņa kas dod iespēju koksnes pārstrādātājiem izvēlēties iespējami stiprāko koksni speciāliem nišas produktiem. No pētītajām koku sugām egles stumbrā blīvuma svārstības ir vismazākās un visblīvākā koksne atrodas aplievas ārējā dal̦ā, pie 10-40\% relatīvā stumbra augstuma. Salīdzinot ar pārējām pētītajām koku sugām, apses koksne attiecībā uz reducēto blīvumu ir viendabīgākā, jo pretēji priedei un eglei, agrīnās un vēlīnās koksnes īpatsvara jeb gadskārtu platuma ietekme uz koksnes blīvumu ir salīdzinoši neliela. Latvijas PSR atkarībā no mizas krāsas izdalīja trīs apses formas: zaļā, gaišpelēkā un tumšpelēkā, secinot, ka zaļās un gaišpelēkās apses koksnes blīvums ir mazāks nekā tumšpelēkām apsēm (Smilga, 1967). Mūsu pētījumā šāds apses dalījums netika praktizēts, līdz ar to nav iespējams pārliecināties par dažādu apšu genotipu, ietekmi uz koksnes blīvumu.

Vairumam koku sugu, bet jo īpaši skujkokiem, vidējo koksnes blīvumu gan tā izmaiņas radiālajā virzienā būtiski ietekmēe gadskārtu platums. Piemēram, duglāzijai (Pseudostuga menziesii) agrīnās koksnes blīvums vidēji ir piecas reizes mazāks nekā vēlīnai koksnei, savukārt dažādu sugu eglēm vēlīnās koksnes blīvums parasti ir apmēram divas reizes lielāks (Saranpää, 2003). Vēlīnās koksnes īpatsvars parasti mazāks ir pirmajās gadskārtās virzienā no serdes un palielinās virzienā uz mizu. Tas izskaidro, kāpēc pētītajām koku sugām juvenīlai koksnei parasti ir vismazākais blīvums.

Daudzām koku sugām, īpaši priedēm, ir izteikta tendence koksnes blīvumam strauji palielināties virzienā no serdes uz mizu, turpretī eglei koksnes blīvuma izmaiņas nav tik izteiktas, lai gan blīvums mainās plašā amplitūdā (Saranpää, 1994). Citā pêtījumā autors analizējis 240 parastās egles augušas 48 dabiskas izcelsmes un stādītās mežaudzēs, konstatējot pārsteidzoši lielas reducētā blīvuma vērtību svārstības radiālajā virzienā dažādos egles stumbros, lai arī koksnes paraugi bija bez acīm redzamiem defektiem (Saranpää, 2003). 
Minētajā pētījumā novērotās egles koksnes blīvuma izmaiņu tendences un svārstību amplitūda dažādos koka augstumos ir identiskas mūsu pētījumā novērotajam (3.6. attēls).

Meklējot nozīmīgākos koksnes blīvuma izmaiṇu cēloṇus, Wilhelmsson et al. (2002) analizējuši 252 egles un 120 priedes paraugkokus no dažādām mežaudzēm, aptverot plašu geogrāfisko reǵionu un dažādus augšanas apstākḷus, koku vecumus un dimensijas. Pētījumā secināts, ka krūšaugstuma caurmērs, gadskārtu skaits un temperatūras summa kopā raksturo $50 \%$ no egles blīvuma izmaiņām un 59\% no priedes blīvuma izmaiņām. Kopumā tikai neliela daļa no blīvuma izmaiņām bija izskaidrojamas ar dažādu kokaudžu atšksirībām un augšanas apstākl̦iem.

Meža mēslošanas ietekme uz egles koksnes blīvumu ir pētīta Zviedrijā (Mäkinen, Saranpää, \& Linder, 2002). Pētījumā noskaidrots, ka parauglaukumos, kuros tika ienestas papildus barības vielas, koku radiālais pieaugums palielinājās vairāk kā trīs reizes, bet vidējais koksnes blīvums samazinājās vairāk nekā par 20\%. Proporcionāli vairāk blīvums samazinājās vēlīnā koksnē. Identiska blīvuma samazināšanās skujkoku koksnes stumbra šķērsgriezumā novērota arī pēc intensīvas kokaudzes retināšanas, bet kopumā retināšanai un mēslošanai ir liela ietekme un blīvuma izmaiņām tikai jaunaudzēs, kamēr koku vainagi vēl nav saslēgušies (Saranpää, 2003).

\subsection{Koku biomasas aprēḳini un vienādojumu izstrāde}

\subsubsection{Biomasas struktūra}

Vajadzība noskaidrot visas kokaudzes vai atsevišķu koka frakciju (piemēram, stumbra, zaru vai sakņu) biomasu ir aktualizējusies pēdējos 20 gados, kopš UNFCCC un Kioto protokola viens no uzdevumiem ir ierobežot un samazināt galveno SEG plūsmu uz atmosfēru, kā arī palielināt piesaistītā oglekḷa apjomus. Informācija par koku biomasas struktūru ir nepieciešama izstrādājot biomasas vienādojumus, gan plānojot racionālu meža apsaimniekošanu un koksnes izmantošanu, kā arī meža uzraudzībā (Schepaschenko et al., 2018).

Kokaudžu biomasas ievērojamu daļu, kura atsevišķiem kokiem var sasniegt pat $70 \%$, veido nestumbru frakciju kā zaru un sakṇu biomasa (3.3. tabula). Pirms Kioto protokola pieņemšanas datu iegūšana par nestumbru biomasu nebija īpaši aktuāla, jo koka zaru un sakņu izmantošanas apjomi bija ḷoti nelieli. Tādēḷ daudzu valstu, tostarp Latvijas, rīcībā esošo informāciju par zaru un sakṇu biomasu var uzskatīt kā fragmentāru un šîs biomasas daļas noteikšanas metodes ir izstrādātas nepilnīgi (Liepa \& Blija, 2008).

3.3. tabula

\section{Paraugkoku biomasas frakciju raksturojums, kg}

\begin{tabular}{clcccc}
\hline Koku suga & Frakcija & Vidēji & Standartnovirze & Min. & Maks. \\
\hline \multirow{5}{*}{ Priede } & 1. Celms & 10.2 & 18.5 & 0.1 & 103.3 \\
& 2. Balstsaknes & 17.4 & 27.8 & 0.1 & 123.9 \\
& 3. Sīkas saknes & 3.3 & 4.2 & 0.1 & 17.3 \\
& 4. Stumbrs & 165.7 & 181.7 & 0.1 & 998.9 \\
& 5. Miza & 9.8 & 10.1 & 0.1 & 59.0 \\
& 6. Dzīvie zari & 24.9 & 21.9 & 0.4 & 107.7 \\
& 7. Sausie zari & 4.4 & 4.8 & 0.0 & 23.1 \\
& 1. $+2 .+3$. & 30.1 & 49.0 & 0.1 & 244.4 \\
& 4. $+5 .+6 .+7$. & 204.8 & 211.8 & 0.6 & 1143.6 \\
\hline
\end{tabular}


3.3. tabulas nobeigums

\begin{tabular}{|c|c|c|c|c|c|}
\hline Koku suga & Frakcija & Vidēji & Standartnovirze & Min. & Maks. \\
\hline \multirow{9}{*}{ Egle } & 1. Celms & 8.7 & 12.8 & 0.2 & 50.9 \\
\hline & 2. Balstsaknes & 19.4 & 27.5 & 0.3 & 100.0 \\
\hline & 3. Sīkas saknes & 4.1 & 4.0 & 0.4 & 16.6 \\
\hline & 4. Stumbrs & 133.1 & 147.1 & 0.4 & 536.9 \\
\hline & 5. Miza & 10.2 & 10.8 & 0.1 & 36.7 \\
\hline & 6. Dzīvie zari & 44.6 & 40.9 & 1.3 & 165.7 \\
\hline & 7. Sausie zari & 4.1 & 4.8 & 0.0 & 17.2 \\
\hline & 1. $+2 .+3$ & 32.2 & 43.4 & 0.9 & 167.4 \\
\hline & 4. $+5 .+6 .+7$ & 192 & 198.6 & 1.8 & 737.1 \\
\hline \multirow{9}{*}{ Bērzs } & 1. Celms & 6.6 & 9.3 & 0.1 & 47.1 \\
\hline & 2. Balstsaknes & 11.3 & 17.6 & 0.1 & 96.9 \\
\hline & 3. Sīkas saknes & 4.6 & 4.4 & 0.2 & 16.5 \\
\hline & 4. Stumbrs & 109.4 & 126.6 & 0.7 & 522.3 \\
\hline & 5. Miza & 15.2 & 18.2 & 0.2 & 99.2 \\
\hline & 6. Dzīvie zari & 15.9 & 23.9 & 0.3 & 150.3 \\
\hline & 7. Sausie zari & 0.6 & 1.0 & 0.0 & 5.9 \\
\hline & 1. $+2 .+3$. & 22.5 & 30.1 & 0.4 & 146.1 \\
\hline & $4 .+5 .+6 .+7$ & 141 & 165.8 & 1.2 & 709.3 \\
\hline \multirow{9}{*}{ Apse } & 1. Celms & 4.5 & 8.2 & 0.1 & 34.0 \\
\hline & 2. Balstsaknes & 9.8 & 20.1 & 0.1 & 89.0 \\
\hline & 3. Sīkas saknes & 2.6 & 3.5 & 0.1 & 13.3 \\
\hline & 4. Stumbrs & 86.7 & 110.5 & 0.5 & 453.1 \\
\hline & 5. Miza & 11.2 & 14.0 & 0.2 & 63.1 \\
\hline & 6. Dzīvie zari & 12.6 & 16.8 & 0.2 & 69.3 \\
\hline & 7. Sausie zari & 3.4 & 5.5 & 0.0 & 27.4 \\
\hline & 1. $+2 .+3$ & 16.9 & 31.4 & 0.3 & 136.3 \\
\hline & 4. $+5 .+6 .+7$ & 113.9 & 143.9 & 0.9 & 612.6 \\
\hline
\end{tabular}

Analizējot pētīto koku sugu dažādu biomasas frakciju īpatsvaru kopējā biomasā, secināts, ka to alometriskās sakarības mainās atkarībā no koku sugas un kokaudzes attīstības pakāpes (3.7. attēls). Vairumā gadījumos pie 3.7. attēlā norādītajiem koku vecumiem stumbrs (koksne un miza) ir lielākā biomasas frakcija, iznemot pirmās vecumklases priedes un egles. Vislielākais stumbra frakcijas īpatsvars galvenās cirtes vecumā novērots bērzam $-78.2 \%$, bet vismazākais eglei - 58\%. Konstatēts, ka tikai jaunaudžu vecuma priedēm un eglēm zaru biomasa ir lielāka par stumbra biomasu. Vislielākais zaru īpatsvars (skaitot kopā sauso un dzīvo zaru masu) kopējā biomasā novērots līdz 20 gadus vecām eglēm; visiem paraugkokiem zaru īpatsvars bija robežās no $45.8-58.3 \%$, bet vidēji $52.8 \%$. Identisku vecumu sasniegušām priedēm kopējais zaru biomasas īpatsvars ir nedaudz mazāks nekā eglēm - vidēji 45.5\%, kas daḹji saistîts ar lielāku sauso zaru īpatsvaru. Tā kā priede ir gaismas prasīga koku suga, tad tās vainaga lejasdaḷā, gaismas trūkuma rezultātā, agri sākas apakšējo zaru atmiršanas process un sauso zaru ipatsvars līdz 20 gadu vecumam var sasniegt pat $4.4 \%$ no visa koka masas. Analizētajiem egles paraugkokiem līdz 20 gadu vecumam sauso zaru īpatsvars nepārsniedza $0.8 \%$ no visa koka masas. Kopumā visām koku sugām novērota tendence, ka zaru biomasas īpatsvars samazinās, pieaugot koka vecumam. Piemēram, ciršanas vecumu sasniegušām eglēm un priedēm vidējais zaru biomasas īpatsvars, attiecīgi $18.3 \%$ un 9.5\%, ir ievērojami mazāks, salīdzinot ar jauniem kokiem. Iepriekšminētā tendence mazāk izteikta lapkoku sugām; bērzam zaru īpatsvars kopējā biomasā samazinās vidēji no $18.4 \%$ uz 4.8\%, bet 
ciršanas vecumu sasniegušām apsēm, palielinoties koku vecumam, zaru īpatsvars samazinās no $15.9 \%$ uz $13.1 \%$.

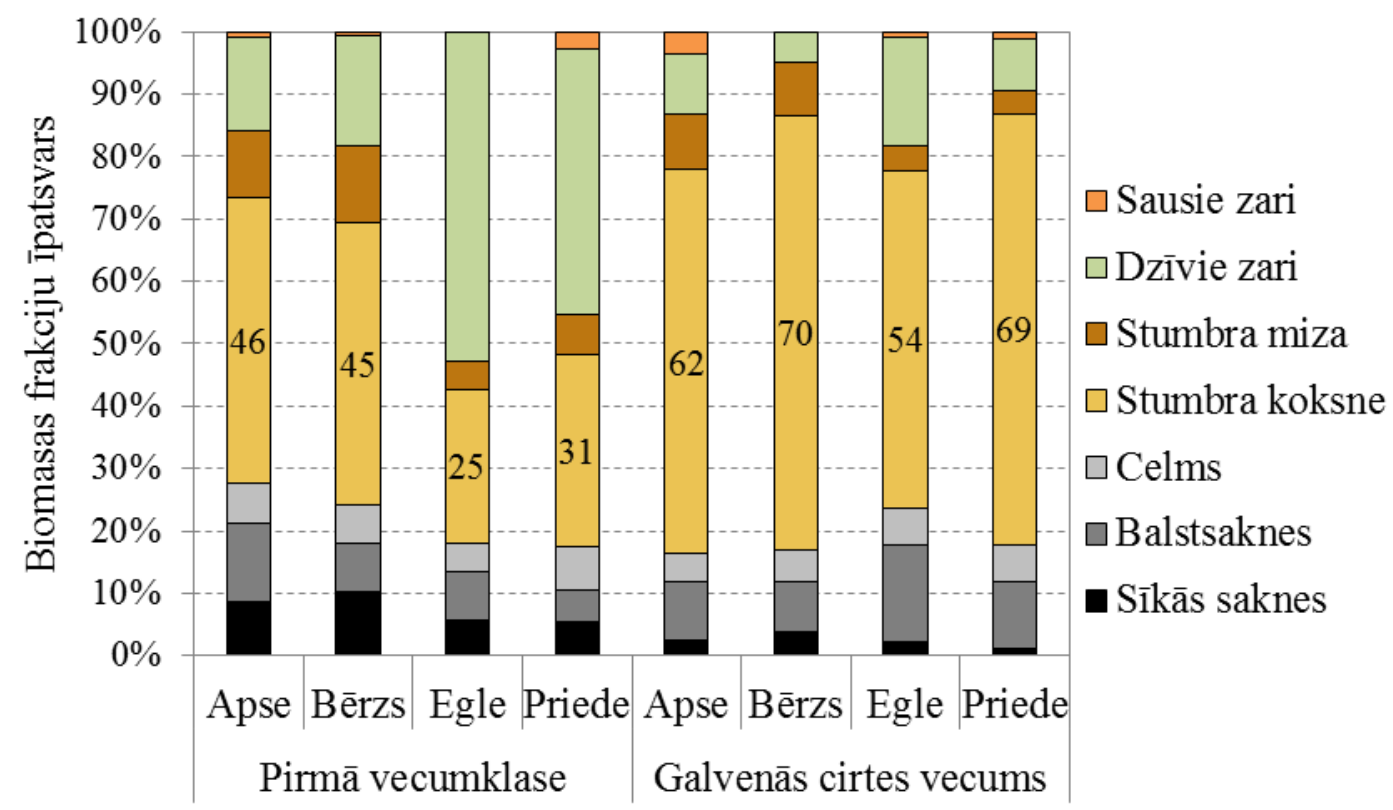

\section{7. att. Kopējās biomasas sadalījums sauso zaru, dzīvo zaru, stumbra mizas, stumbra koksnes, celma, balstsakṇu (> $2 \mathrm{~cm})$, un sīko sakṇu $(<2 \mathrm{~cm})$ frakcijās}

Pirmā vecumklase apsei un bērzam ir 0 - 10 gadi, priedei un eglei 0 - 20 gadi, bet galvenās cirtes vecums apsei pieṇemts 41 , bêrzam 71 , eglei 81 , priedei 101 gads

Promocijas darbā atsevišķi netika nodalīts āra un purva bērzs, bet Zviedrijā, ierīkojot dažādas biezības stādījumus ar abām iepriekšminētajām sugām, konstatēta ne tikai kopējā biomasas atšķirība viena vecuma kokiem, bet arī biomasas īpatsvara atšķirības starp virszemes un celma/sakṇu biomasas frakcijām (Johansson, 2007). Autors secinājis, ka 12 gadu vecumā vienādos apstākḷlos augušu āra bērzu kopējā biomasa un virszemes biomasas īpatsvars ir lielāks nekā purva bērzam, norādot uz proporcionālu lielāku sakṇu masu purva bērzam. Lielāka sakņu masa palīdz purva bērzam papildus nodrošināties pret izgāšanos vēja ietekmēe, jo tas pārsvarā aug kūdras augsnēs kur augsnes noturība nav tik liela kā minerālaugsnēs.

Pētījumā koku celma, balstsakņu un sīko sakṇu īpatsvars no kopējā biomasā visām koku sugām kopā vidēji ir apmēram 20\% un identiski secinājumi iegūti arī Somijā, nosakot kopējo priedes, egles un bērza celma/sakņu biomasu (Repola, 2013). Lapkokiem bērzam un apsei lielāks celma/sakṇu biomasas īpatsvars ir jauniem kokiem, bet mazāks pieaugušiem kokiem. Savukārt skujkoku sugām priedei un eglei ir pretēji (3.7. attēls). Apsei celma/sakṇu biomasas ipatsvars, pieaugot koka vecumam, samazinās visstraujāk, no $27.6 \%$ vidēji pirmajos 10 gados līdz 16.3\% sasniedzot galvenās cirtes vecumu. Bērzam celma/sakṇu biomasas īpatsvars pirmajos 10 gados vidēji ir $24.0 \%$, bet galvenās cirtes vecumā vairs tikai $16.9 \%$. Attiecībā uz priedi vidējais celma/sakņu biomasas īpatsvars, palielinoties koka vecumam, pieaug tikai nedaudz; pirmajos 20 gados tas ir 17.6\%, bet 101 gada vecumā vidēji $17.7 \%$ un var teikt, ka tas ir gandrīz konstants. Galvenās cirtes vecumā egles celma/sakṇu biomasas īpatsvars, salīdzinot ar pārējām koku sugām, ir vislielākais, vidēji 23.7\%, kamēr līdz 20 gadu vecumam tas vidēji ir 18\%. Pieaugot koka vecumam, atšķiras ne tikai kopējais celma/sakṇu biomasas īpatsvars, bet arī sakṇu biomasas sadalījums pa frakcijām. Vislielākās izmaiņas skar tieši sīko sakņu (mazāku par $<2 \mathrm{~cm}$ ) īpatsvaru, kurš pirmās vecumklases kokiem bija robežās no 5.4$10.2 \%$, bet galvenās cirtes vecumā vairs tikai no $1.0-3.9 \%$.

Visā pasaulē sakarības starp dažādu koku sugu virszemes biomasas frakcijām ir salīdzinoši labi izprastas un aprakstītas, bet zināšanas par sakṇu biomasu un tās īpatsvaru 
ietekmējošajiem faktoriem, joprojām ir diezgan ierobežotas. Dažkārt, izpratnes palielināšani par oglekḷa apriti un tā uzkrāšanos dažādās sauszemes ekosistēmās, informācija par kopējo koka biomasu ir l̦oti nozīmīga. Celma/sakņu biomasas precīza uzmērīšana ir saistīta ar lielu darbietilpību un izmaksām, tāpēc daudzos pētījumos tā tiek novērtēta netieši - no aprēķinātiem vai precīzi uzmērītiem koku virszemes biomasas datiem (Cairns et al., 1997). Plaši izplatīta metode, aprēķinot celma/sakņu kopējo biomasu, ir pielietot virszemes un sakṇu masas attiecību (angl̦u val. root to shoot ratio) (Mokany, Raison, \& Prokushkin, 2006). Virszemes un sakņu masas attiecību var piemērot arī atsevišķu koku celma/sakṇu biomasas aprēķināšanai, bet biežāk tā tiek piemērota biomasas aprēķināšanai kokaudzes līmen̄̄, vai daudz plašākā mērogā - atsevišķiem meža tipiem, biomiem, ekologiskajām zonām vai geogrāfiskajiem reg̣ioniem.

Valstīm, kurām nav savas koku celma/sakņu biomasas aprēķina metodikas, IPCC labas prakses vadlīnijas (Eggleston et al., 2006) iesaka izmantot vidējās virszemes un sakṇu masas attiecības, jeb pārrēķina koeficientu noklusējuma vērtības atkarībā no ekologiskajām zonām. Mērenās joslas mežiem vadlīniju piedāvātās vērtības ir robežās no 0.20 pieaugušiem līdz 0.40 jauniem skujkoku mežiem un attiecīgi 0.24-0.46 lapkoku mežiem, bet visiem boreālās joslas mežiem no 0.24-0.39. Mūsu pētījumā iegūtās virszemes un sakṇu masas attiecības vērtības ir robežās no $0.20-0.25$ priedei, $0.21-0.30$ eglei, $0.23-0.34$ bērzam un $0.21-0.39$ apsei (3.8. attēls).

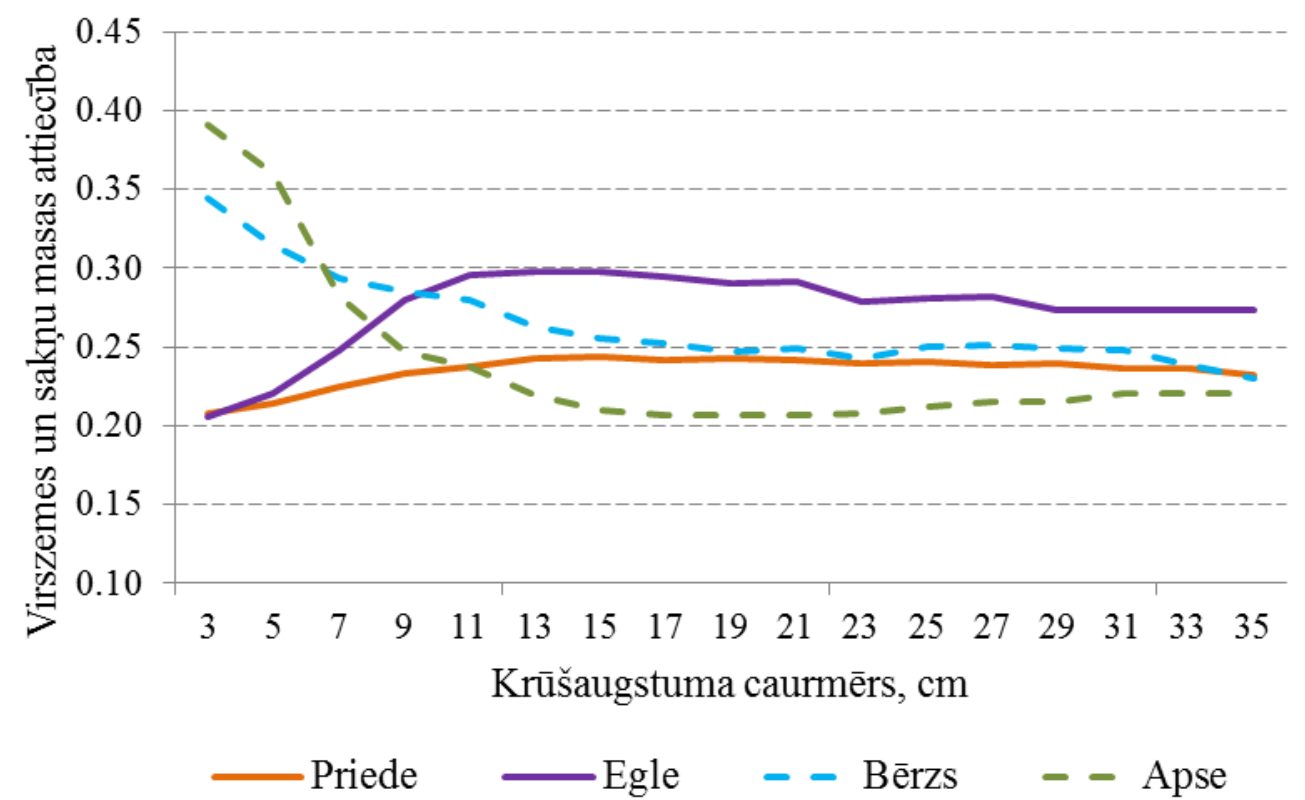

\section{8. att. Virszemes uz sakṇu biomasas pārrēķina attiecības izmaiṇas atkarībā no koku krūšaugstuma caurmēra}

Pētījumā analizētās skujkoku (priede, egle) un lapkoku (bērzs, apse) sugas, atkarībā no koku krūšaugstuma caurmēra, uzrādīja atšķirīgas virszemes un sakņu masas attiecības izmaiņas palielinoties koka dimensijām. Līdzịgi kā analizējot dažādu koku sugu biomasas frakciju īpatsvaru atkarībā no koku vecuma (3.7. attēls), arī analizējot caurmēra ietekmi uz virszemes un sakņu masas attiecību, konstatēts, ka mazu dimensiju lapkokiem raksturīgs lielāks celma/sakṇu biomasas īpatsvars kā lielu dimensiju kokiem, bet skujkoku sugām ir pretēji. Pēc 3.8. attēls redzamajām līkṇu izmaiņu tendencēm secināms, ka celma/sakņu biomasas īpatsvars kokiem ar krūšaugstuma caurmēru virs 10-15 cm ir gandrīz konstants.

Mūsu pētījuma rezultāti liecina par to, ka vidējās IPCC vadlīniju virszemes un sakņu masas attiecības vērtības, kuras rekomendētas biomasas aprēķināšanai gan mērenās, gan arī 
boreālās joslas mežos, Latvijas apstākḷos pārvērtē jaunaudžu celma/sakṇu biomasu. Vislielākā biomasas pārvērtēšana notiek skujkoku jaunaudzēs, kurās virszemes biomasa nepārsniedz 50 $75 \mathrm{t} \mathrm{ha}^{-1}$. Tas ir tāpēc, ka IPCC vadlīniju rekomendētās celma/sakņu biomasas aprēķina koeficientu vērtības priežu un egļu jaunaudzēm ir divas reizes lielākas nekā aprēķināts mūsu pētījumā. Dal̦ēji tas skaidrojams ar to, ka joprojām zinātniekiem nav vienotas izpratnes par vietu, kur dalās koka virszemes un celma/sakṇu biomasas. Lielākoties pētījumos šis biomasas frakciju sadalījums balstās uz subjektīvi noteiktu robežu, līdz ar to celma virszemes daļas masa var tikt pieskaitīta gan stumbram, gan sakṇu biomasai. Nosakot virszemes un sakṇu masas attiecību, būtu jāņem vērā tas, kādam mērķim to paredzēts lietot. No fiziologiskā skatupunkta virszemes un sakņu masas attiecība tiek interpretēta tā, lai tā atspoguḷotu fotosintēzes diferenciālo ieguldījumu starp koka virszemes un celma/sakņu biomasas frakcijām (Titlyanova et al., 1999). Šādā gadījumā zemes virma ir atbilstoša vieta virszemes un celma/sakņu biomasas frakciju nodalīšanai. Turpretī, aprēksinot mežā palikušās koksnes masu pēc mežistrādes vai raksturojot oglekl̦a plūsmu starp dažādām krātuvēm, svarīgi ir ņemt vērā to, ka pēc koka nociršanas augsnē paliek ne tikai koka saknes, bet arī celma virszemes daļa, kuras garums varētu būt apmēram $1 \%$ no koka garuma.

Vidējā virszemes un sakṇu masas attiecība priedei, eglei, bērzam un apsei mūsu pētījumā analizētajiem dažādu dimensiju paraugkokiem ir attiecīgi 0.23, 0.26, 0.26 un 0.24. Pētītajām koku sugām vidējās vērtības lielākoties sakrīt ar literatūrā publicētajām vērtībām, taču bija novērojamas arī dažas atšķirības. Lielbritānijā, nosakot tur sastopamo skujkoku sugu virszemes un sakņu masas attiecības, konstatēts, ka parastajai priedei attiecība vidēji ir 0.30 un eglei 0.25 (Levy, Hale, \& Nicoll, 2004), kas ir diezgan līdzīgas vērtības, kuras iegūtas mūsu pētījumā, īpaši eglei. Bērzam virszemes un sakṇu attiecība visiem paraugkokiem ir robežās no 0.17-0.42 kas ir nedaudz mazāk, kā novērots bērza paraugkokiem Norvēǵijā 0.210.88 (Smith et al., 2016). Likumsakarība, ka, palielinoties koku caurmēram vai vecumam samazinās sakņu biomasas īpatsvars, novērota gan mūsu, gan iepriekšminētajā pētîjumā. Vidējā virszemes un sakņu masas attiecība Norvēgijā augušajiem bērziem aprēķināta 0.42 , kas ir ievērojami vairāk nekā aprēķināts mūsu pētījumā (0.26), kā arī citā pētījumā Igaunijā 0.21 (Varik et al., 2013). Smith et al. (2016) pêtījumu atšḳirīgos rezultātus skaidro ar mazāku koku biezību parauglaukumos, kuros analizēti Norvēgijā augušie bērza paraugkoki. Pie mazākas biezības un koku savstarpējās konkurences tie veido lielāku sakņu sistēmu, salīdzinot ar kokiem, kuri auguši lielā biezībā kā Igaunijas pētījumā, kur koku skaits bērza parauglaukumos bijis robežās no 3200-10 000 gab. ha $^{-1}$.

Pētījumā iegūtā visu koku sugu vidējā virszemes un sakṇu masas attiecība ir 0.25 un tā ir ļoti tuva iepriekš publicētajām vērtībām mērenās joslas mežiem - 0.26 un boreālās joslas mežiem - 0.27 (Cairns et al., 1997). Tomēr mūsu rezultāti apliecina, ka vidējo virszemes un sakņu masas attiecību piemērošana atsevišķu kokaudžu līmenī var rezultēties kḷūdainos biomasas aprēķinos, jo attiecību ietekmē gan kokaudzes vecums, gan vidējais koku caurmērs. Tāpēc, atsevišksu kokaudžu vai koku sakņu biomasas raksturošanai, korektāk un precīzāk ir lietot alometriskos vienādojumus, nevis konstantus pārrēķina koeficientus.

\subsubsection{Biomasas vienādojumi}

Empīrisko datu ievākšana pēc destruktīvās metodes individuālu koku biomasas vienādojumu izveidei ir plaši izmantots paņēmiens, kas praktizēts daudzos pētījumos un pielietots arī mūsu darbā. Šādu vienādojumu piemērošanai valsts mērogā, nepieciešams nodrošināt, lai ievāktais empīriskais materiāls būt reprezentatīvs visai mērķa populācijai (Temesgen et al., 2015). Lai nodrošinātu alometrisko vienādojumu ticamību un precizitāti, izstrādātajiem vienādojumiem jābūt balstītiem uz pietiekoši lielu paraugkoku skaitu, vienlaikus meklējot līdzsvaru starp datu ievākšanas precizitāti un pieejamo finansējumu, jo šādu datu ievākšana ir dārga un laikietilpīga. Dažādu simulāciju rezultāti parāda, ka virszemes 
biomasas raksturošanai ir ieteicama vismaz 40 paraugkoku ar regulāru stumbra formu izpēte katrai koku sugai ar priekšnoteikumu, ka paraugkopas koku dimensijas atbilst visai ǵenerālkopai (Roxburgh et al., 2015). Mūsu pētījumā katrai koku sugai paraugkoku atlase bija plānota tā, lai aptvertu plašu Latvijā sastopamo mežaudžu un koku raksturlielumu amplitūdu. Kopā dati tika iegūti no 372 kokiem, 81-105 paraugkoki katrai koku sugai (2.2. tabula). Pēc nacionālā MRM datiem virsvaldu koki, valdošie koki, un līdzvaldu koki (2.2. attēls) veido 97\% no kopējās mežaudžu krājas Latvijas mežos, pamatojot pētījumā izmantoto paraugkoku atlases metodi. Pārējo (nomākto un atmirstošo) koku īpatsvars kopējā mežaudžu krājā ir relatīvi neliels, tāpēc šādi koki netika izvēlēti un pieņemts, ka tas būtiski neietekmēs vienādojumu piemērojamību nacionālā mērogā.

Mūsu pētījumā veiktā visu koka sakṇu virs $2 \mathrm{~mm}$ diametrā izrakšana ir dārga un darbietilpīga metode un tādā apjomā vēl nav veikta nevienā citā pētījumā. Praksē visbiežāk sīko sakṇu masa visiem paraugkokiem tiek aprēḳināta, izmantojot regresijas vienādojumus, kuru izveidei izrakts ierobežots skaits paraugkoku (Repola, 2008, 2009) vai izraktas tikai atsevišķas koka saknes (Petersson \& Stahl, 2006; Smith et al., 2016).

Pētījumā izstrādāto biomasas vienādojumu statistiskie rādītāji, regresijas koeficientu vêrtības un to standartkḷūdas visiem pētījuma ietvaros pārbaudītajiem vienādojumiem ir aplūkojami 3.4. tabula. 
Regresijas vienādojumu koeficientu vērtības un to statistiskie rādītāji

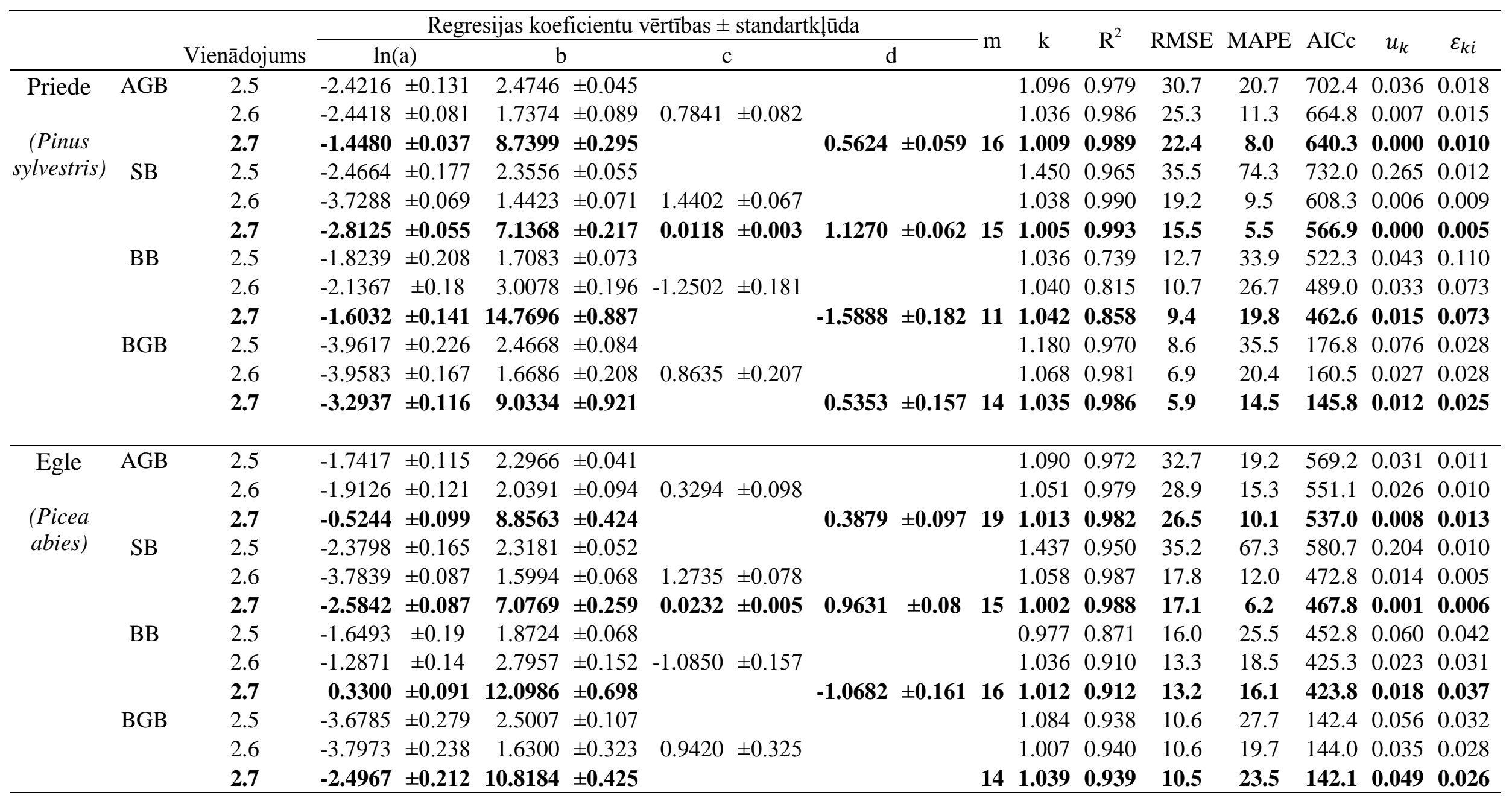


3.4. tabulas nobeigums

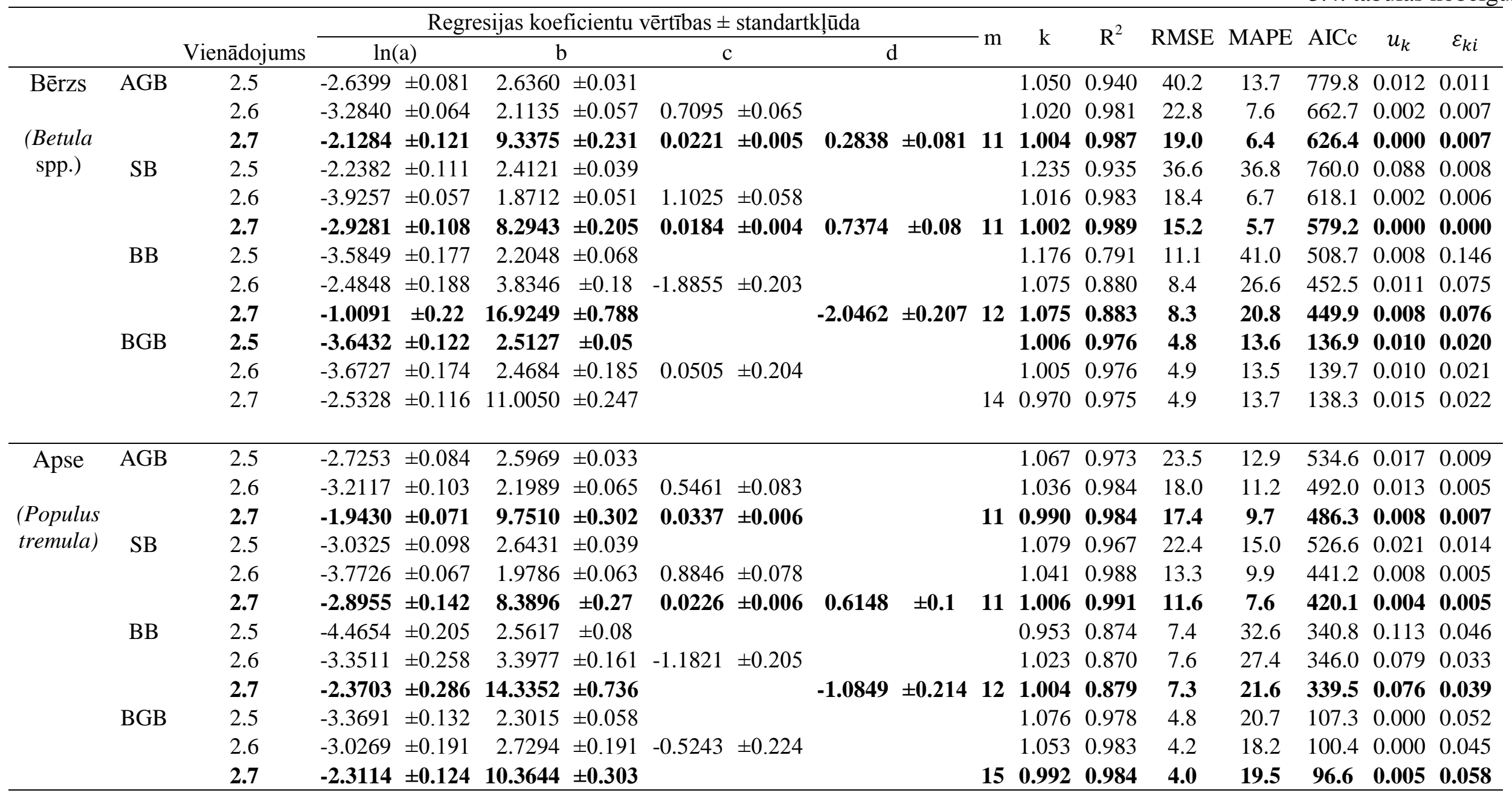

Piezīmes: Rekomendētais vienādojums katrai koka frakcijai iekrāsots treknrakstā. AGB, SB, BB, BGB attiecīgi kopējā virszemes, stumbra, zaru, kopējo celma/sakṇu biomasa.

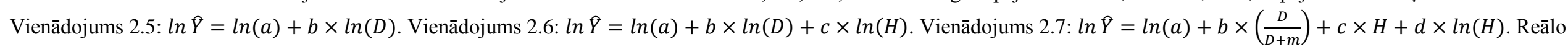

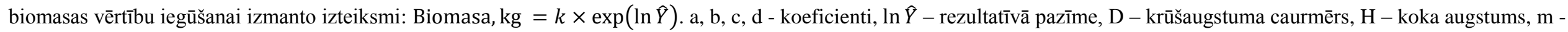
konstante, $\mathrm{k}$ - korekcijas koeficients. $u_{k}-$ ir randomizētais faktors kokaudzei $k, \varepsilon_{k i}$-randomizētais faktors kokam $i$ kokaudzē $k$. 
Katras koku sugas biomasas frakcijai teorētiski labākais vienādojums raksturojas ar zemāko AICc vērtību. Ja starpība starp divām AICc vērtībām ir nulle, tad katram no pārbaudītajiem vienādojumiem ir vienāda (50\%) ticamība būt precīzam un nevar apgalvot, ka kāds no vienādojumiem ir labāks par otru (Motulsky \& Arthur, 2003). Ja starpība starp divām AICc vērtībām ir 2 un, piemēram, vienādojumam A ir zemāka AICc vērtība nekā vienādojumam $\mathrm{B}$, tad ar $73 \%$ ticamību var apgalvot, ka vienādojums $\mathrm{A}$ ir precīzāks par vienādojumu B (3.9. attēls). Vēl viens veids kā interpretēt AICc vērtību starpību ir apgalvot, ka vienādojums A ir 2,7 (73/27=2,7) reizes labāks kā vienādojums B. Ja starpība starp divu vienādojumu AICc vērtībām ir 6, tad jau ar 95\% ticamību un diezgan droši var apgalvot, ka vienādojums A ir labāks (95/5=20 reizes) par vienādojumu B. Bieži vien empīriski ievāktie dati neatbalsta tikai vienu vien vienādojumu, kurš ir piemērots prognozēšanai, tādi var būt arī vairāki. Praksē pieñemts uzskatīt, ka ja divu vienādojumu AICc vērtību starpība ir mazāka par 2 (ticamība $<73 \%$ ) tad nevar īsti droši apgalvot, ka kāds no analizētajiem vienādojumiem ir pārliecinoši labāks par otru (Burnham \& Anderson, 2002) un ir jāveic citas pārbaudes, lai noskaidrotu vai kāds no vienādojumiem, piemēram, neveido sistemātisku novirzi pie noteiktām rezultatīvās pazīmes vērtībām un kā tas ir interpretējams attiecīgajā kontekstā.

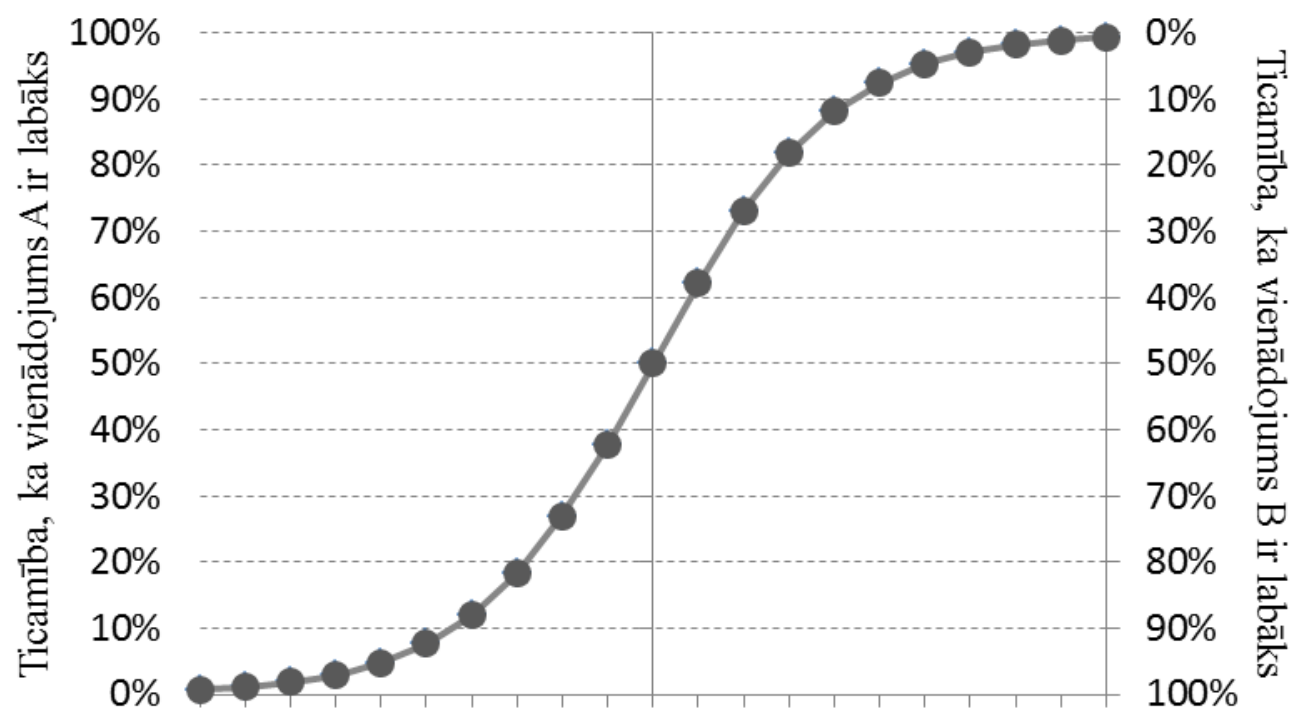

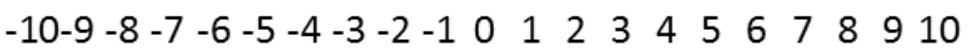

$$
\mathrm{AICC}_{\mathrm{B}}-\mathrm{AICc}_{\mathrm{A}}
$$

\section{9. att. Vienādojumu ticamības novērtējums pēc divu AICc vērtību starpības}

Izņemot bērza BGB, visām pārējām koku sugām un to frakcijām vienādojums 2.7 uzrāda zemākās AICc vērtības, tādējādi minētajā kontekstā pārspējot pārējos pārbaudītos vienādojumus 2.5 un 2.6. Interpretējot iegūtās AICc vērtības, aprēķināta relatīvā varbūtība raksturojot par cik konkrētais vienādojums ir pārāks nekā pārējie (Wagenmakers \& Farrell, 2004). Aprēķinot bērza BGB, 2.5 vienādojumam ir 67\% ticamība būt labākajam, salīdzinot ar 2.7 vienādojumu, bet $80 \%$ ticamība būt labākam nekā 2.6 vienādojums. Savukārt 2.7 vienādojumam ir vismaz 53\%, 66\%, 68\% ticamība būt labākajam salīdzinot ar 2.5 un 2.6 vienādojumiem, aprēķinot attiecīgi egles $\mathrm{BGB}$, apses $\mathrm{BB}$, egles $\mathrm{BB}$, bet vairāk nekā $73 \%$ ticamība (starpība starp 2.7 un pārējo vienādojumu AICc vērtībām bija lielāka par 6) būt labākajam aprēķinot biomasu pērējām biomasas frakcijām.

Pēc AICc vērtību analīzes 2.5 vienādojums teorētiski labāks par 2.6 vienādojumu ir ne tikai prognozējot bērza BGB, bet arī egles BGB un apses BB apjoma prognozēšanā ar ticamību būt pārākam attiecīgi $80 \%$ un 93\%. Pārējām biomasas frakcijām diezgan droši var 
apgalvot, ka par 2.5 vienādojumu labāks ir 2.6 vienādojums, jo visos gadījumos ticamība bija lielāka par $88 \%$.

Izvēloties piemērotāko egles BGB, bērza BGB, egles BB un apses BB vienādojumu, jāvērtē pārējie vienādojumu statistiskie rādītāji un jāpielieto citas vienādojumu novērtěšanas metodes. Iepriekšminēto koku sugu biomasas frakciju labākajam vienādojumam ir tikai attiecīgi 1.1, 2.0, 2.1 un 1.9 reizes lielāka varbūtība būt pareizam attiecībā pret nākamo vienādojumu ar otru zemāko AICc vērtību, kas ir maznozīmīgi, lai noraidītu pārējos vienādojumus.

Regresijas koeficientu nenoteiktību parasti raksturo tā standartkḷūda. Pārāk liela koeficienta standartkḷūda ir pietiekošs iemesls vienādojuma noraidīšanai, ja vien no tā netiek izslēgta kāda faktoriālā pazīme, tādējādi samazinot paliekošo koeficientu standartkḷūdu un līdz ar to palielinot koeficientu ticamību. Mūsu pētījumā katra vienādojuma regresijas koeficientu ticamība pārbaudīta ar PRSE un visiem analizētajiem 2.5 vienādojuma koeficientiem (3.4. tabula) PRSE nepārsniedza 30\%, kura mūsu pētījumā pieñemta kā kritiskā robeža, lai noraidītu vienādojumu. Turpretī egles, bērza un apses BGB 2.6 vienādojumam atsevišksu koeficientu PRSE vērtības ir attiecīgi 35\%, 403\% un 93\%, norādot uz vienādojumu nepiemērotību BGB aprēķiniem. 2.7 vienādojuma statistiskā analīze parādīja, ka tikai priedes, egles, bērza, apses SB un bērza AGB vienādojums visprecīzāk aprēksina biomasu pēc tās sākotnējās izteiksmes. Pārējām biomasas frakcijām $\mathrm{H}, \ln (\mathrm{H})$ vai abu minēto faktoriālo pazīmju izslēgšana no 2.7 izteiksmes samazināja AICc vērtību vai bija saistīta ar nepien,emami lielu regresijas koeficentu PRSE.

Sileshi (2014) norāda, ka vienādojumus, kuriem PRSE vienam vai vairākiem regresijas koeficientam ir lielāka par $25 \%$, vispār nedrīkstētu publicēt, jo tie nav ticami. Autors arī norāda, ka vides zinātņu pētījumos PRSE kritiskajām robežvērtībām vajadzētu būt vēl zemākām, attiecīgi 20\%. Tomēr citā pētījumā, kurā veikta biomasas vienādojumu statistiskā analīze demonstrēts, ka PRSE robežvērtība $25 \%$ ir nepamatoti zema novērtējot koeficientu uzticamību un tā atbilst $10^{-5}-10^{-4}$ būtiskuma līmenim (Picard et al., 2015). Autors norāda, ka minētais būtiskuma līmenis ir vairāk nekā 5\%, kas tiek tradicionāli lietots ekologijāā, tāpēc PRSE robežvērtības varētu būt arī augstākas par $25 \%$.

Visiem vērtētajiem vienādojumiem (3.4. tabula) $R^{2}$ uzrādīja ciešu sakarību starp mērītajām un aprēķinātajām biomasas vērtībām, iekl̦autajiem argumentiem izskaidrojot 73.3$99.3 \%$ no rezultatīvās pazīmes variēšanas. 2.7 vienādojums kopumā uzrādīja visaugstākās $R^{2}$ vērtības, izskaidrojot 85.8-99.3\% no biomasas vērtību variēšanas. Attiecīgi nedaudz mazāka izskaidrotā variācija ir 2.6 vienādojumam $81.5-99.0 \%$, bet vismazākā tā ir 2.5 vienādojumam 73.9-97.9 \%. Kopumā visām koku sugām, aprēķinot BB, jārēķinās ar lielāku prognozēšanas kḷūdu, salīdzinot ar pārējām biomasas frakcijām, to atspoguḷo arī sliktākas $\mathrm{R}^{2}$ un MAPE vērtības. Aprēķinot BB ar rekomendētajiem vienādojumiem (3.4. tabula), konstatētas vidēji par $10.1 \%$ (7.1-12.7\%) mazākas $\mathrm{R}^{2}$ vērtības, salīdzinot ar pārējo biomasas frakciju vidējo $\mathrm{R}^{2}$ vērtīibu.

Regresijas vienādojumu novērtēšanai zinātniskajā literatūrā plaši izplatîta un samērā vienkārši pielietojama metode ir aprēķināto un prognozēto vērtību attiecināšana. Pēc vērtību attiecināšanas veic lineāro regresiju, ar kuru novērtē iegūtās taisnes novirzi no 1:1 iedomātās līnijas (ideālajā gadījumā regresijas koeficienti $a=0$ un $b=1$ ). Ja lineārās regresijas koeficienti $a \neq 0$ un $b \neq 1$, tad tas norāda uz nepietiekamu vienādojuma precizitāti un mūsu pētījuma kontekstā uz sistemātisku biomasas pārvērtēšanu vai pretēji - biomasa tiek novērtēta mazāk. Darba ietvaros katrai koka biomasas frakcijai rekomendēto vienādojumu (3.4. tabula) aprēksināto un prognozēto biomasas vērtību grafisks attēlojums un regresijas koeficientu vērtību analīze neuzrādīja statistiski būtisku regresijas taisnes novirzi no 1:1 iedomātās līnijas (3.10. attēls). 


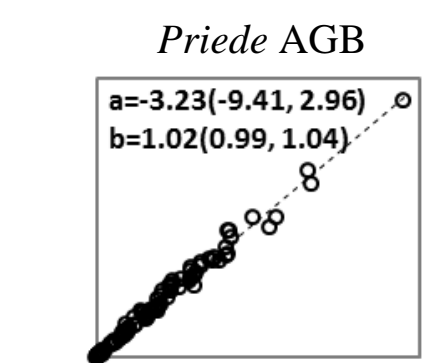

Priede SB

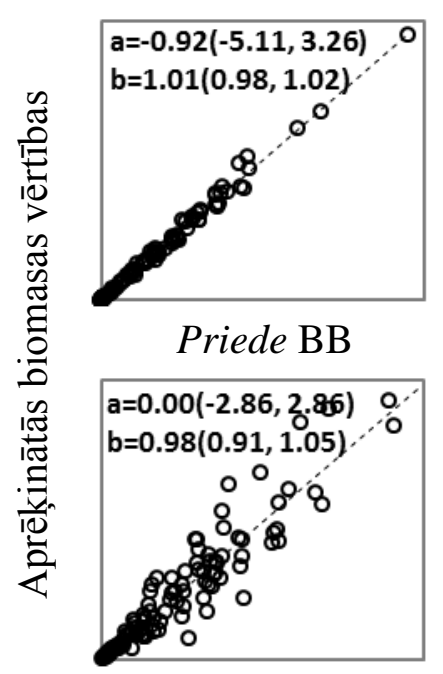

Priede $\mathrm{BGB}$
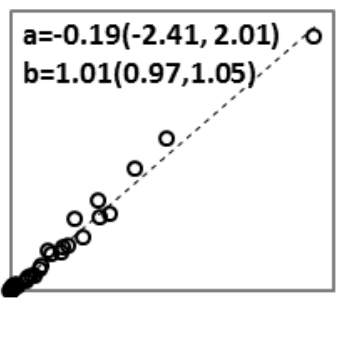

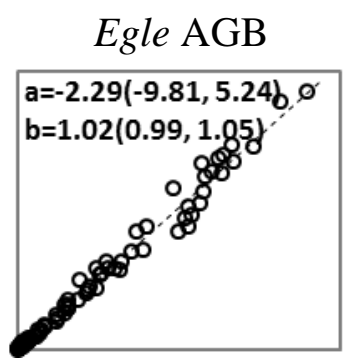

Egle SB

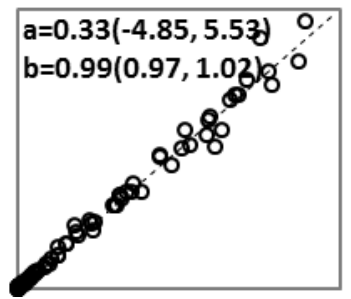

Egle $\mathrm{BB}$

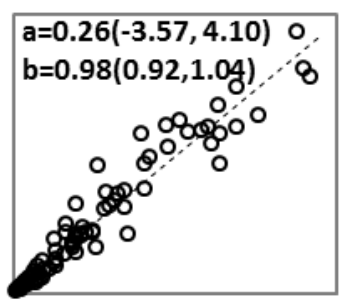

Egle BGB

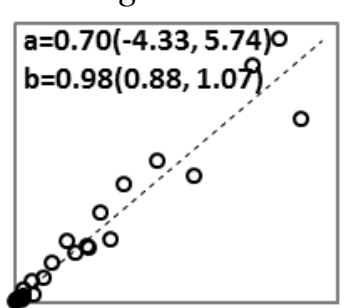

Bērzs AGB

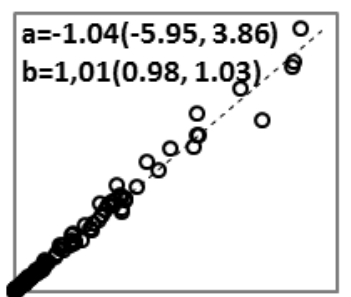

Bērzs SB

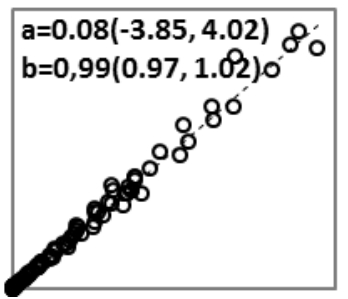

Bērzs BB

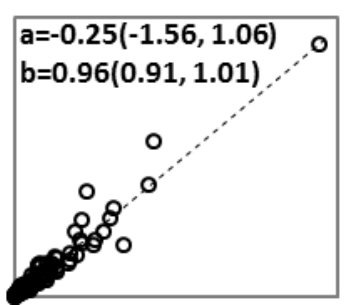

Bērzs BGB

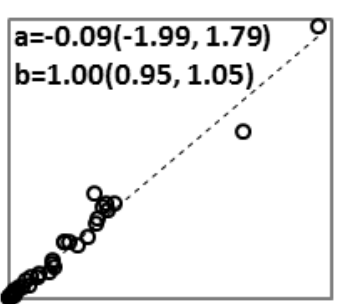

Prognozētās biomasas vērtības
Apse AGB

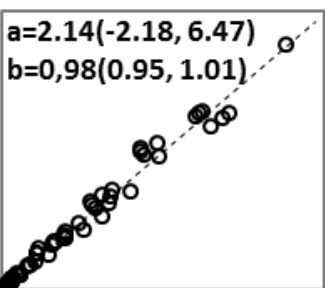

Apse SB

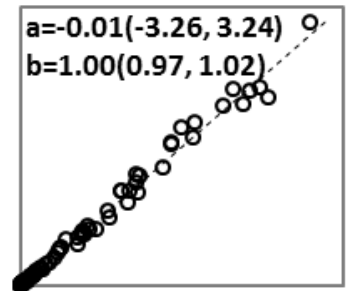

Apse BB

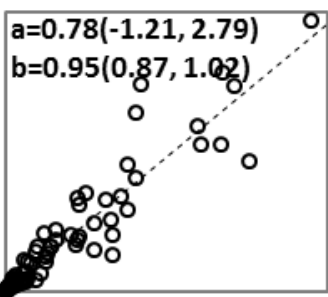

Apse BGB

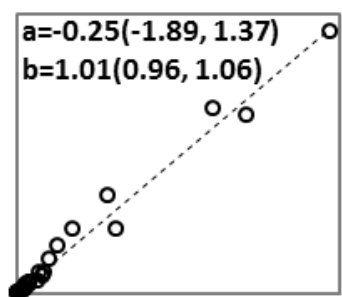

\subsection{0. att. Aprēķināto un prognozēto biomasas vērtību izkliedes diagramma un regresijas taisne.}

Prognozētās vērtības aprēḳinātas izmantojot rekomendētos vienādojumus (3.4. tabula) katras koku sugas biomasas frakcijai. Vērtības uz X un $\mathrm{Y}$ asīm katrai diagrammai ir vienādas. a un b - lineārās regresijas koeficienti un iekavās to $95 \%$ ticamības intervāls. AGB - virszemes biomasa, SB - stumbra biomasa, BB - zaru biomasa, BGB - celma/sakṇu biomasa

Attēlojot un analizējot aprēķināto un prognozēto vērtību izkliedes diagrammas, svarīgi aprēķinātās vērtības likt uz Y ass, bet prognozētās uz X ass, jo pretējā gadījumā iegūtie rezultāti būs kḷūdaini (Piñeiro et al., 2008). Lineārās regresijas a un b koeficientu atbilstîba izvirzītajiem kritērijiem veikta, analizējot koeficientu 95\% ticamības intervālus. Ja koeficientam a 95\% ticamības intervāls ietver 0 vērtību, tad nevar noraidīt hipotēzi, ka a=0. Tāpat, ja koeficienta b 95\% ticamības intervāls ietver vērtību 1, tad nevar noraidīt hipotēzi, ka $\mathrm{b}=1$. Iepriekš aprakstītā aprēķināto un prognozēto biomasas vērtību savstarpējā analīze apstiprināja, ka biomasas frakciju rekomendētie vienādojumi (3.4. tabula) neveido sistemātisku novirzi no empīriski ievāktajiem datiem, līdz ar to vienādojumi ir lietojami biomasas prognozēšanā. Pētījuma kontekstā parasti šāda nevēlama novirze veidojas, lielu dimensiju kokiem pastiprināti ietekmējot regresijas koeficientu vērtības, dēl lielākas to ietekmes, salīdzinot ar mazākiem kokiem. 
Vadoties pēc Piñeiro et al. (2008) novērojumiem, aprēķināto un prognozēto biomasas vērtību izkliedes diagrammas analīze ir visbiežāk lietotā vienādojumu novērtēšanas metode zinātniskajā literatūrā. Neskatoties uz metodes popularitāti, joprojām daudzos gadījumos tā tiek lietota nepareizi vai nepilnīgi (Sileshi, 2014). Visizplatītākā kḷūda ir aprēķinātās vērtības likt uz $\mathrm{X}$ ass, bet prognozētās uz $\mathrm{Y}$ ass. Minētā kḷūda neietekmē $\mathrm{R}^{2}$ vērtības, jo abos gadījumos tās būs identiskas, bet nepareiza vērtību atlikšana uz X un Y asīm dod kḷūdainu regresijas koeficientu 95\% ticamības intervāla novērtējumu. Jo mazākas $\mathrm{R}^{2}$ vērtīibas, jo lielāka būs kḷūda, samainot abas asis vietām (Piñeiro et al., 2008). Pēc autora secinājumiem dažkārt aprēksināto un prognozēto vērtību analīze aprobežojas tikai ar $\mathrm{R}^{2}$ atspogulošanu vai izkliedes diagrammas attēlošanu, kas būtībā sniedz nepilnīgu priekšstatu par vienādojumu precizitāti.

Novērtējot izstrādāto vienādojumu ticamību dažādu mainīgo lielumu diapazonā, pētījumā pārbaudīta vienādojumu atlikumu sadalījuma normalitāte (angḷu val. residual analysis). Relatīvā starpība starp aprēķinātajām un prognozētajām biomasas vērtībām katram apskatītajam izstrādātajam vienādojumam attiecināta pret logaritmiski transformētām prognozētajām biomasas vērtībām (3.11. attēls, 3.12. attēls, 3.13. attēls). Prognozētās biomasas vērtības atlikumu izkliedes diagrammās ir transformētas, lai vienlīdz labi varētu atklāt sistemātisku novirzi pie lielām un mazām biomasas vērtībām. Lai izstrādātais vienādojums būtu izmantojams prognozēšanā, tā atlikumu izkliedes diagrammās izvilktajai līnijai nedrīkst parādīties būtiskas novirzes no vidējās vērtības, kā arī punktiem ir jābūt nejauši izkārtotiem.

2.7 vienādojuma piemērošanas gadījumā nevienai koku sugas biomasas frakcijai nebija nevēlamu tendenču, kas norādītu uz sistemātiskām vienādojuma atlikumu novirzēm no vidējās vērtības (3.11. attēls). Aprēķinot $\mathrm{AGB}$ un $\mathrm{SB}$, lokālas prognozēšanas kḷūuas nebija lielākas par, attiecīgi $\pm 5.1 \%$ un $\pm 4.8 \%$. Savukārt aprēķinot BB vai BGB pēc 2.7 vienādojuma, lokālas prognozēšanas kḷūdas bija nedaudz lielākas, attiecīgi $\pm 6.9 \%$ un $\pm 6.8 \%$.

Aprēķinot biomasu pēc 2.6 un 2.5 vienādojumiem (3.12. attēls, 3.13. attēls), gandrīz visām biomasas frakcijām vienādojumu atlikumos novērojamas sistemātiskas kḷūdas, kuras pārsniedza $10 \%$ robežu no vidējās vērtības. Tas vairumā gadījumos nozīmē nepietiekami precīzu biomasas novērtēšanu jauniem kokiem, īpaši skujkokiem. Ja atlikumu vidējā vērtība ir negatīva, tad pētījuma kontekstā tas norāda, ka konkrētais vienādojums prognozē biomasu vairāk nekā ir aprēķināts pēc empīriski ievāktajiem datiem un pretēji, ja atlikumu vidējā vērtība ir pozitīva. Prognozējot BGB pēc 2.5 vienādojuma, atlikumu novirze no vidējās vērtības bija ievērojami mazāka kā pārējām biomasas komponentēm. Tas norāda, ka raksturojot BGB koka $\mathrm{H}$ ir mazāka ietekme, salīdzinot ar pārējām biomasas komponentēm. Arī prognozējot egles, bērza un apses BGB pēc 2.7 vienādojuma, $\mathrm{H}$ izslēgšana no izteiksmes samazināja lokālas atlikumu novirzes no vidējās vērtības. 

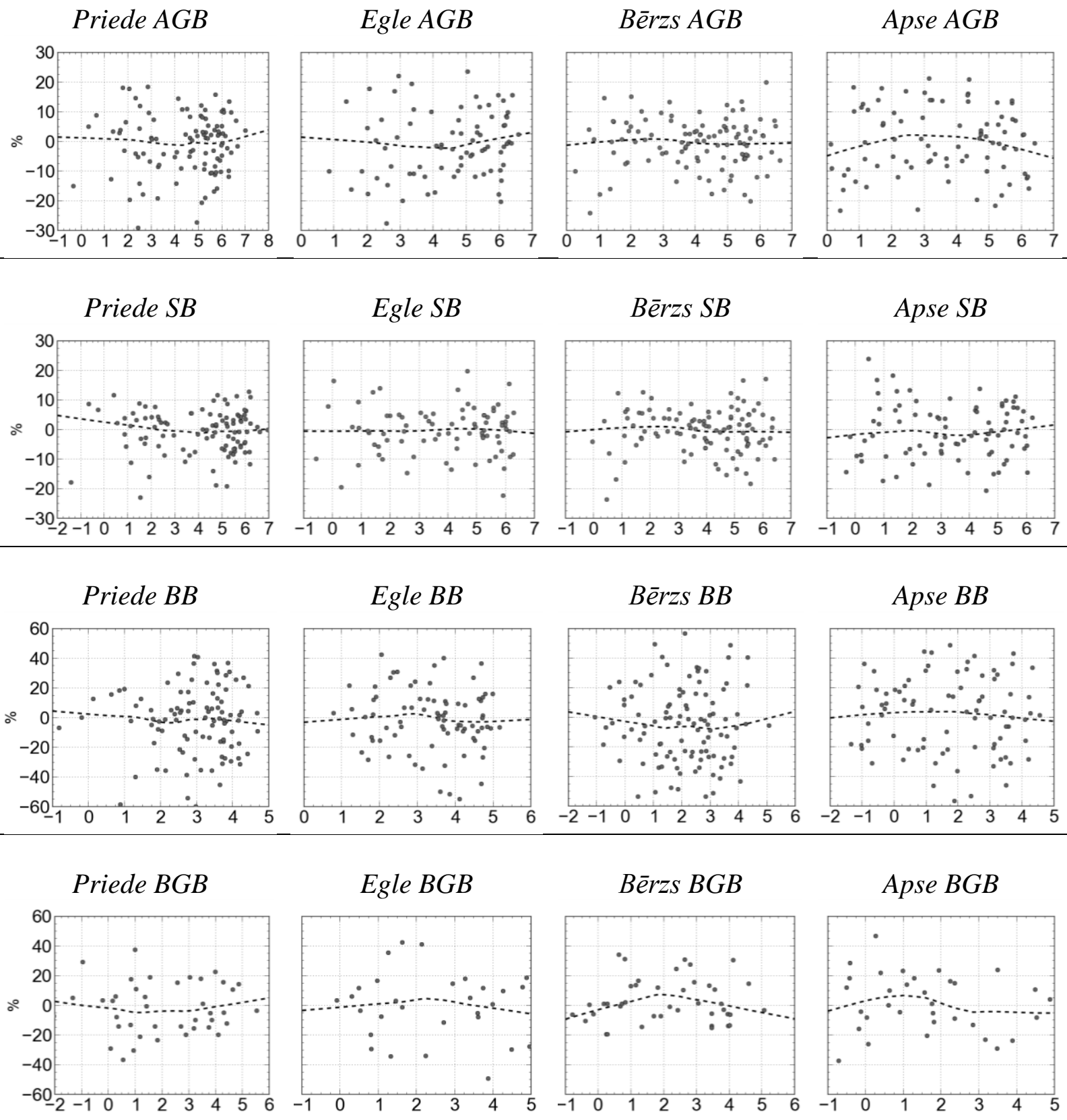

Transformētas biomasas vērtības

\subsection{1. att. Vienādojuma 2.7 atlikumu sadalījuma struktūra}

Pārtrauktā līnija attēlota, izmantojot LOWESS regresiju. AGB - virszemes biomasa, SB stumbra biomasa, BB - zaru biomasa, BGB - celma/sakṇu biomasa 

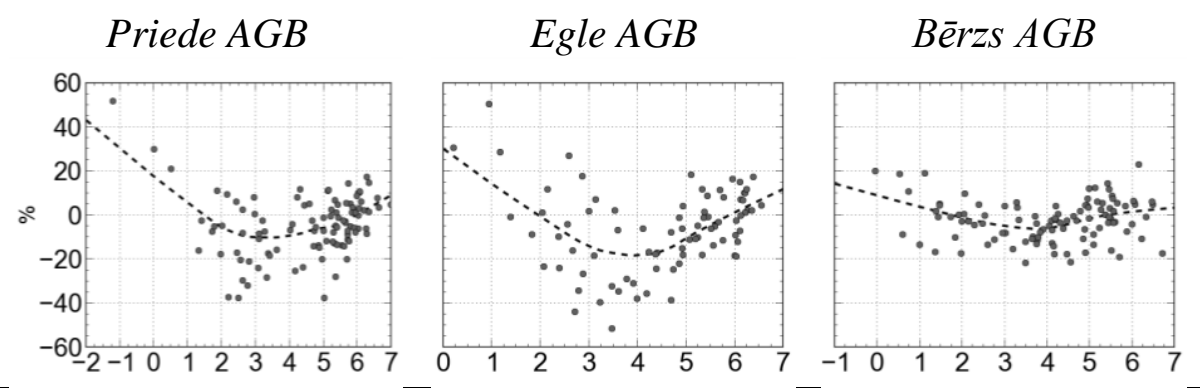

Apse $A G B$
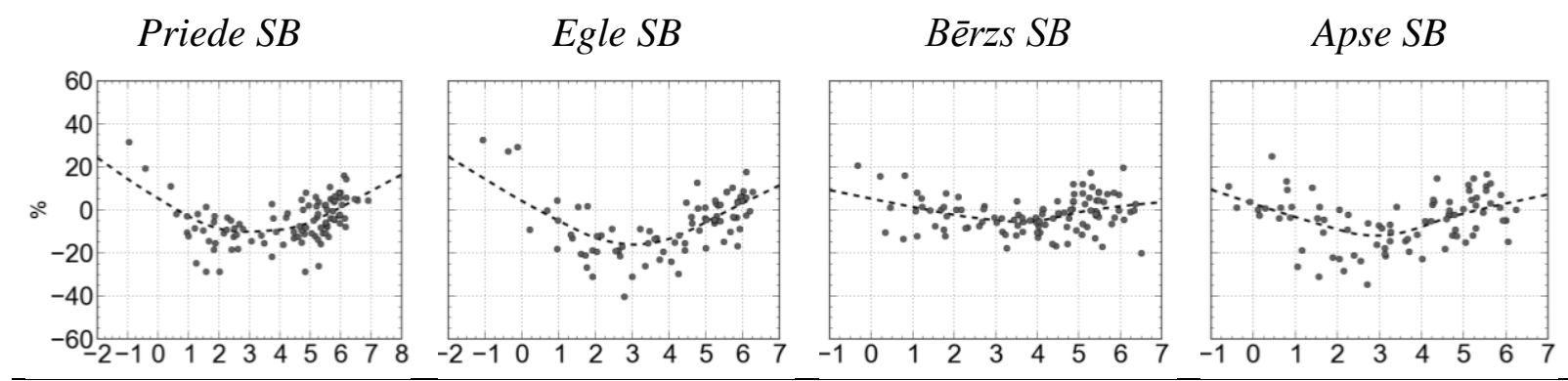

Priede $B B$

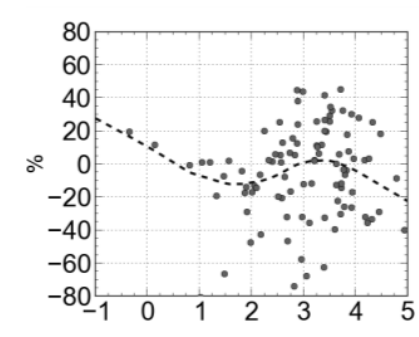

Egle BB

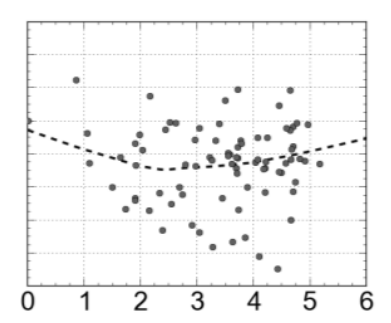

Bērzs BB

Apse BB
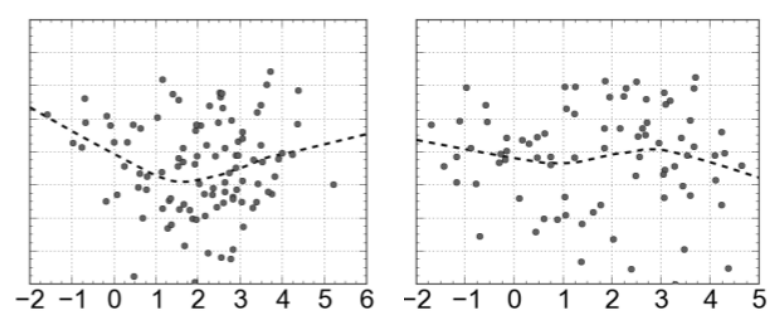

Priede $B G B$

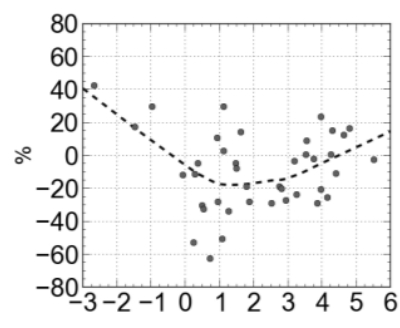

Egle BGB

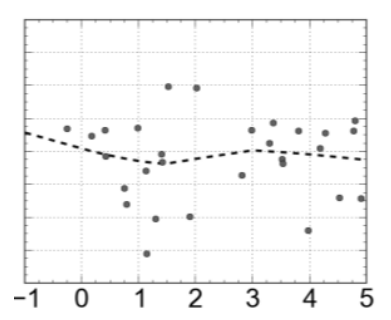

Bērzs BGB

Apse BGB
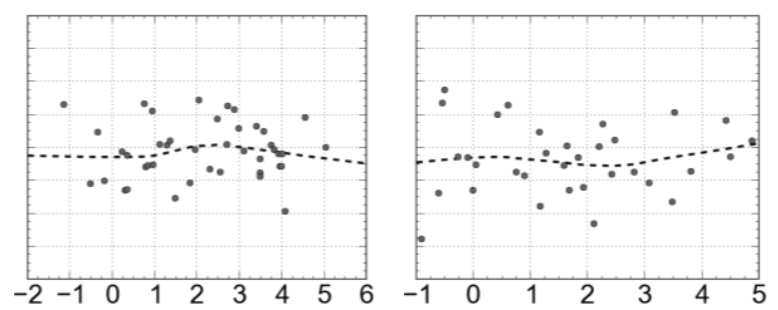

Transformētas biomasas vērtỉbas

\subsection{2. att. Vienādojuma $\mathbf{2 . 6}$ atlikumu sadalījuma struktūra}

Pārtrauktā līnija attēlota, izmantojot LOWESS regresiju. AGB - virszemes biomasa, SB stumbra biomasa, BB - zaru biomasa, BGB - celma/sakņu biomasa 

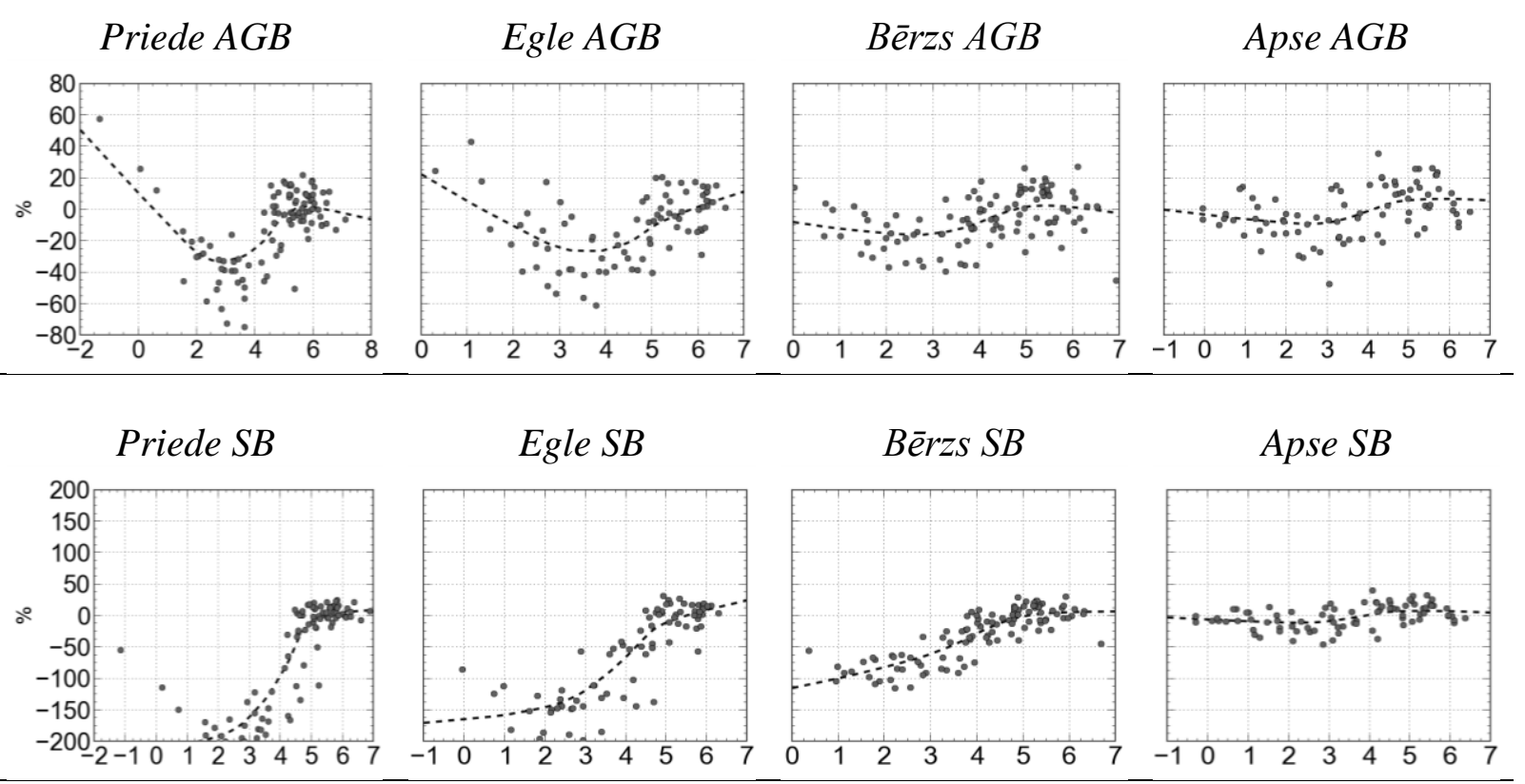

Priede $\mathrm{BB}$

Egle $B B$

Bērzs BB

Apse BB
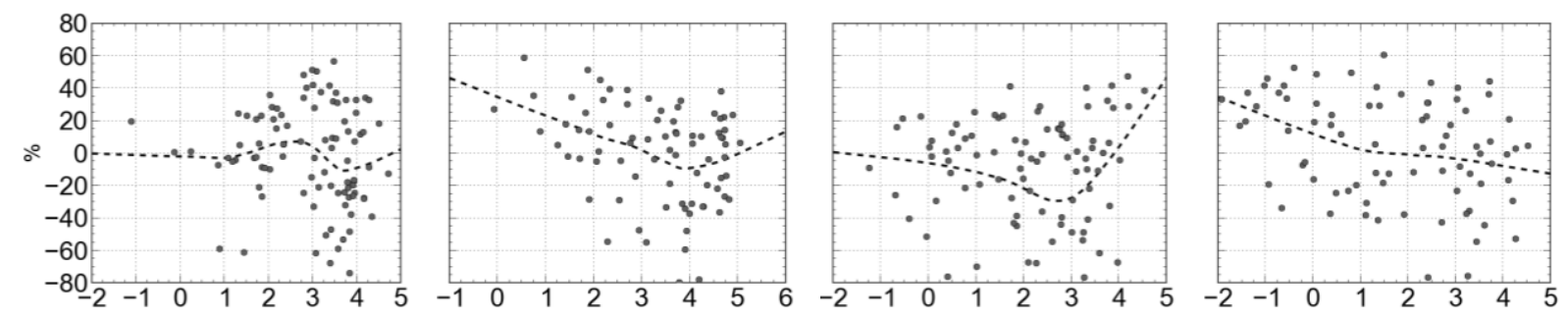

Priede $B G B$

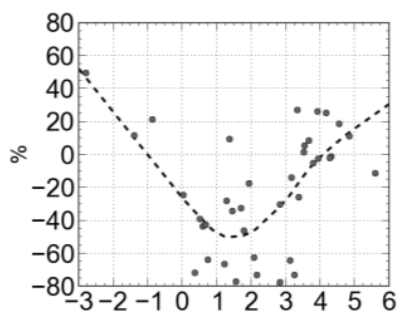

Egle $B G B$

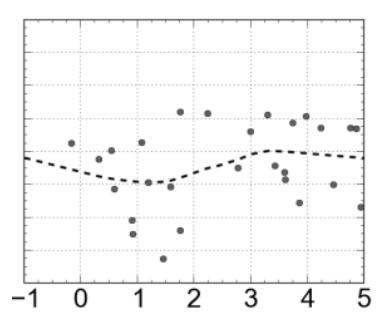

Bērzs $B G B$

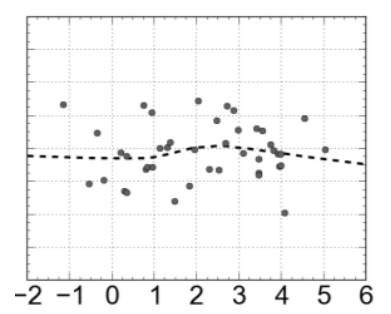

Apse BGB

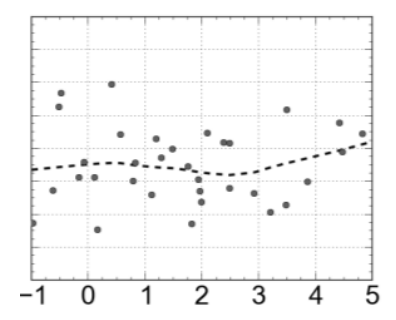

Transformētas biomasas vērtības

\subsection{3. att. Vienādojuma 2.5 atlikumu sadalījuma struktūra}

Pārtrauktā līnija attēlota, izmantojot LOWESS regresiju. AGB - virszemes biomasa, SB stumbra biomasa, BB - zaru biomasa, BGB - celma sakṇu biomasa

Mūsu pētījuma rezultāti apliecina, ka visu koku sugu biomasas vienādojumi, kuros kā mainīgie parametri iekḷauti $\mathrm{D}$ un $\mathrm{H}$, uzrāda zemākas MAPE vērtības, norādot uz zemāku vidējo procentuālo prognozēšanas kḷūdu. Tomēr citi statistiskie rādītāji (RMSE, AICc un $\mathrm{R}^{2}$ ) norādīja uz to, ka koku $\mathrm{H}$ iekḷaušana vienādojumos ne vienmēr uzlabo to prognozēšanas precizitāti, jo īpaši, aprēķinot koku kopējo BGB un sīkāko sakṇu biomasu (Liepiņš et al., 2017). Piemēram, aprēķinot apses BB, 2.5 vienādojums uzrādīja labākas statistisko rādītāju (RMSE, AICc un $\mathrm{R}^{2}$ ) vērtības salīdzinot ar 2.6 vienādojumu. Tomēr pārējiem virszemes biomasas frakciju (AGB, SB, BB) aprēķinu vienādojumiem neatkarīgi no koku sugas $\mathrm{H}$ iekḷaušana ievērojami uzlaboja to precizitāti. 
Kā jau iepriekš ir norādījis Jenkins et al. (2003), zinātnieku vidū bieži vien ir pretrunīgi viedokḷi par koka D kā vienīgā argumenta izmantošanu koka biomasas modelēšanā. Pētījumā tropiskajos mežos ir aprēķināts, ka kokaudzes biomasas aprēķinu standartkḷūda ir par 7\% lielāka, ja nav pieejami koku augstuma mērījumi, tādā veidā uzsverot koku $\mathrm{H}$ nozīmi virszemes biomasas aprēķinos (Chave et al., 2005). Tāpat arī Lima et al. (2012) salīdzināja sešus alometriskos biomasas vienādojumus un secināja, ka vienādojumi kuros kā arguments bija ietverts koku $\mathrm{H}$, uzrādīja labākus statistiskos rādītājus, salīdzinot ar tiem, kuros kā vienīgais arguments bija D. Zviedrijā veiktajā pêtījumā pierādījās, ka īpaši jaunās priedes, egles un bērza kokaudzēs $\mathrm{D}$ un $\mathrm{H}$ kombinācija ievērojami samazina biomasas aprēksinu nenoteiktību, bet tāpat ar to bija nepietiekami, lai izskaidrotu būtiskas biomasas atšksirības starp dažādām mežaudzēm (Claesson et al., 2001). Autori norāda, ka biomasas nenoteiktība starp dažādām mežaudzēm visticamāk veidojas, ignorējot koku zaļā vainaga garumu, kurš mainās atkarībā no koku skaita platības vienībā. Iekḷaujot vienādojumos zaḷā vainaga garumu kā papildus argumentu, biomasas nenoteiktība starp mežaudzēm bija normas robežās.

Saprotams, ka koka H un zaļā vainaga garums ir ļoti svarīgi parametri koku virszemes biomasas prognozēšanā, tomēr šīs ir visgrūtāk precīzi izmērāmās koka pazīmes. Precīza koku $\mathrm{H}$ datu iegūšana pati par sevi dažkārt ir diezgan sarežğìts uzdevums, īpaši kokaudzēs ar augstiem kokiem un blīviem vainagiem, kā arī pie lielas koku biezības. Piemēram, tropiskajos mežos kokiem H mērījumu precizitāte parasti svārstās no 3-20\%, kā rezultātā biomasas aprēķinu nenoteiktība uz ha ${ }^{-1}$ ir apmēram 6\% (Hunter et al., 2013). N̦emot vērā koku H mērījumu augsto nenoteiktību tropiskajos mežos, ir aprēķināts, ka dažkārt biomasas vienādojumi bez koku H ir pat līdz trijām reizēm precīzāki (Phalla et al., 2017).

Somijas dienvidos veiktajā pētījumā raksturota 319 individuālu koku D un H mērīšanas precizitāte priedei, eglei un bērzam to neatkarīgi veicot četriem profesionāliem uzmērītājiem (Luoma et al., 2017). Minētajā pētījumā noskaidrots, ka koku D un $\mathrm{H}$ mērījumu standartnovirze vidēji bija $0.3 \mathrm{~cm}(1.5 \%)$ un attiecīgi $0.5 \mathrm{~m}(2.9 \%)$ kas ir ievērojami zemāka nekā tropiskajos mežos, turklāt netika konstatētas arī statistiski būtiskas atšķirības starp dažādu cilvēku uzmērījumiem. Par cik koku augšanas apstākḷi Latvijā ir diezgan līdzīgi apstākḷiem Somijas dienvidos, pētījums netieši norāda, ka augošu koku uzmērījumus arī mūsu platuma grādos ir iespējams veikt ar pietiekošu precizitāti, lai koku H iekḷautu kā argumentu izstrādātajos vienādojumos. Vairāki autori (Andersen, Reutebuch, \& McGaughey, 2006; Ene et al., 2012) ir pierādījuši, ka ar LIDAR ir iespējams iegūt l̦oti precīzus koku H un D datus un šai metodei ir ievērojams potenciāls koku mērījumu precizitātes palielināšanai nacionālajā mērogā.

Darba ietvaros atspoguḷotie vienādojumu statistiskie rādītāji un veiktās pārbaudes norāda uz to, ka vairumā gadījumos (izņemot bērza BGB) 2.7 vienādojums, salīdzinot ar 2.5 un 2.6 vienādojumu, ir vispiemērotākais pētīto koku sugu biomasas frakciju aprēķiniem. Novērots, ka 2.7 vienādojuma izteiksme ir piemērota arī jaunu koku biomasas aprēķiniem, jo tā ir pietiekoši elastīga, atšksirībā no 2.5 un 2.6 vienādojumu izteiksmēm. Skujkokiem, prognozējot biomasu pēc 2.5 vienādojuma, atlikumu novirze no vidējās vērtības vislielākā bija tieši jauniem kokiem ar D mazāku par $10 \mathrm{~cm}$ (3.13. attēls). Neskatoties uz to, ka $\mathrm{H}$ iekl̦aušana pakāpes vienādojumā (2.6) samazināja atlikumu novirzi no vidējās vērtības, joprojām vairumam koku frakciju, vislielākā novirze tika konstatêta jauniem kokiem (3.12. attēls).

Arī citi autori ir konstatējuši, ka pakāpes vienādojumi ne vienmēr korekti raksturo koku biomasas izmaiņas atkarībā no dažādiem main̄̄gajiem (Picard et al., 2015). Līdzīgus novērojumus kā mūsu pētījumā par pakāpes vienādojumiem ir aprakstījis Muukkonen (2007), aprēksinot biomasu dažādām Eiropā izplatîtām koku sugām, savos pētîjumos secinot, ka pakāpes vienādojumi nav pietiekoši elastīgi biomasas aprēķiniem, īpaši mazāku diametru kokiem. Tāpat arī logaritmiski pārveidota pakāpes funkcija ne vienmēr piemērojama visām situācijām, lai arī tā parasti dod ticamus rezultātus vispārīgai biomasas prognozēěanai (Claesson et al., 2001). 
Pētījumā biomasas aprēksinu nenoteiktība starp dažādām kokaudzēm un vienas kokaudzes ietvaros analizēta pielietojot lineāros jaukta tipa modeļus. Prognozējot koku frakciju biomasu pēc 2.5 vienādojuma, vairumā gadījumos (izņemot priedes BB, bērza BB, bērza BGB, apses BGB) mazāka aprēķinu nenoteiktība ir individuālu koku biomasas aprēksiniem konkrētā kokaudzē. Tas liecina par to, ka vienādojumi būs mazāk precīzi, piemērojot tos biomasas aprēķiniem ārpus kokaudzes, kur nozāgèeti paraugkoki. H iekḷaušana pakāpes vienādojumos samazināja kopējo biomasas aprēķinu nenoteiktību vidēji par 37\%, ievērojami uzlabojot biomasas aprēķinu precizitāti. $\mathrm{D}$ un $\mathrm{H}$ kombinācija pakāpes vienādojumos vairāk samazināja aprēķinu nenoteiktību, saistītu ar biomasas izmain̄ām starp dažādām kokaudzēm (visām koku sugām un frakcijām vidēji 49\%), bet mazāk konkrētas kokaudzes individuālu koku biomasas aprēķiniem (visām koku sugām un frakcijām vidēji 26\%). H iekḷaušana pakāpes vienādojumos visvairāk samazināja SB aprēķinu kopējo nenoteiktību - vidēji par 64\%, bet vismazāk BGB aprēķinu nenoteiktību - vidēji par $16 \%$. Viskorektāk biomasas variēšanu mūsu pētījumā raksturoja 2.7 vienādojums, kura izmantošana salīdzinot ar 2.5 vienādojumu, biomasas aprēķinos vidēji par $61 \%$ samazināja aprēķinu nenoteiktîbu.

Ir pieņemts uzskatīt, ka biomasa dažādu koku sugu frakcijās (zari, stumbrs, saknes) vienādu dimensiju kokiem variē starp dažādām kokaudzēm un arī konkrētas kokaudzes līmen̄̄. Mūsu pêtījumā apstiprinājās jau iepriekš literatūrā paustās atziņas (Claesson et al., 2001; Repola, 2008, 2009), ka biomasas aprēķinu nenoteiktība starp dažādām kokaudzēm ir ievērojami mazāka nekā konkrētas kokaudzes ietvaros. Tāpēc, prognozējot biomasu pēc rekomendētajiem vienādojumiem (3.4. tabula), mazāka aprēķinu nenoteiktība būs visas kokaudzes, nevis atsevišķu koku biomasas aprēķiniem. Papildus main̄̄go iekļaušana vienādojumu izteiksmēs vairāk samazina aprēķinu nenoteiktību starp dažādām kokaudzēm, nekā nenoteiktību vienas kokaudzes ietvaros (Repola, 2013). Tas izskaidro, kāpēc mūsu pētījumā uz D balstītie biomasas vienādojumi vairumam koku frakciju uzrādīja sliktākus prognozēšanas rezultātus salīdzinājumā ar vienādojumiem, kuru izteiksmēe iekḷauts arī $\mathrm{H}$. Koku D un H kombinācija vienādojumos nodrošina to, ka tie korektāk izskaidro biomasas atšķirības, kas veidojās koku savstarpējās konkurences rezultātā (Claesson et al., 2001).

Izstrādājot biomasas vienādojumus ir svarīgi, lai atsevišķu koka frakciju (stumbrs, zari) prognožu summa ir vienāda ar kopējo prognozēto biomasu (Bronisz et al., 2016; Kozak, 1970; Repola, 2008, 2009). Mūsu pētījumā prognozētā SB un BB summa diezgan labi atbilst kopējām AGB prognozēm, tāpēc papildus procedūras biomasas vienādojumu aditivitātes nodrošināšanai netika veiktas. Izmantojot rekomendētos biomasas aprēķina vienādojumus, SB un BB summa vidēji apsei ir par $0.2 \%$, bērzam par $0.5 \%$, eglei par $0.5 \%$ un priedei par $0.8 \%$ lielāka nekā koku sugām atbilstošās AGB prognozes. Iegūtā novirze mūsu pētījumā ir līdzīga citam pētījumam Somijā, kur novirze pēc additivitātes koriǵēšanas eglei bija $2.3 \%, 3.7 \%$, $4.5 \%$ bet priedei $0.2 \%, 1.1 \%, 1,2 \%$ atkarībā no pielietotās vienādojuma izteiksmes (Repola, 2009).

\subsubsection{Vienādojumu validācija}

Darba ietvaros izstrādātie priedes, egles un bērza AGB un BGB vienādojumi salīdzināti ar Ziemel̦eiropas valstīs izstrādātajiem biomasas aprēķina vienādojumiem, kuru izmantošana ir akceptēta, sastādot nacionālos inventarizācijas ziņojumus par ZIZIMM sektoru valstī. Atsevišş̧u koku augstuma un caurmēra mērījumi no 2571 priedēm, 2671 eglēm, 2379 bērziem un 2316 apsēm, kuri iegūti ierīkotajos pagaidu parauglaukumos visos atlasītajos meža nogabalos (2.1. tabula), izmantoti kā materiāls biomasas vienādojumu validēšanai.

Priedes, egles un bērza AGB un BGB salīdzināšanai, izvēlēti vienādojumi no Zviedrijas (Marklund, 1988; Petersson \& Stahl, 2006), Somijas (Repola, 2008, 2009), kā arī bērza vienādojumi no Norvēgijas (Smith et al., 2014, 2016). Priedei un eglei Norvēǵi lieto Zviedrijā 
izstrādātos vienādojumus. Parastai apsei AGB salīdzināta tikai ar Zviedrijā izstrādātiem biomasas vienādojumiem atsevišksi mazākiem un lielākiem kokiem, jo šajā valstī nav kopīga vienādojuma visu dimensiju kokiem. Apsēm ar D mazāku par $11 \mathrm{~cm}$ biomasa rēḳināta pēc Johansson (2000) ieteiktajiem vienādojumiem, bet kokiem ar D virs $11 \mathrm{~cm}$ biomasa aprēķināta pēc Johansson (2002) vienādojumiem, sekojot autora rekomendācijām. Citu Ziemel̦eiropas valstu apses vienādojumi (Korsmo, 1995; Simola, 1977) netika iekļauti, jo tie paredzēti biomasas novērtēšanai tikai jaunaudzēs ar koku krūšaugstuma diametru mazāku par $16 \mathrm{~cm}$. Literatūrā netika atrasts neviens apses BGB vienādojums ar ko salīdzināt mūsu pētījuma datus. Tā kā mūsu pētījumā lapu biomasa netika iekļauta, visos gadījumos no salīdzināšanai izmantotajiem AGB vienādojumiem bērzam un apsei tā tika izslēgta, turpretī skujkokiem tā ir iekl̦auta kopējā AGB.

Balstoties uz vizuālu biomasas aprēķinu līkņu salīdzinājumu (3.14. attēls), vairums salīdzināto AGB un BGB vienādojumu (izņemot apses AGB un bērza BGB vienādojumus) uzrādīja līdzīgas biomasas izmaiņas. Apses AGB, aprēksināta pēc Johansson (2000, 2002) vienādojumiem, uzrādīja ievērojamu biomasas pārvērtēšanu kokiem ar D lielāku par $35 \mathrm{~cm}$. Savukārt bērza BGB aprēķini pēc Repola (2008) vienādojuma, lielākajiem kokiem aprēķināja par 46\% mazāku biomasu, nekā aprēķināts pēc mūsu izstrādātā vienādojuma (3.5. tabula). Kopumā Zviedrijā izstrādātie priedes, egles un bērza biomasas vienādojumi (Marklund, 1988; Petersson \& Stahl, 2006) uzrādīja mazākas MAPE vērtības, salīdzinot ar vienādojumiem no Somijas (Repola, 2009), norādot uz precīzāku biomasas aprēķināšanu Latvijas apstākḷos (3.5. tabula). Norvēǵijā izstrādātie biomasas aprēksina vienādojumi bērzam (Smith et al., 2014, 2016) uzrādīja vislabākos prognozēšanas rezultātus, piemērojot tos Latvijas apstākḷiem, uz ko norāda zemākas MAPE vērtības.

3.5. tabula

Promocijas darbā un citos pētījumos izstrādāto vienādojumu biomasas aprēķinu relatīvā starpība atkarībā no vidējā krūšaugstuma caurmēra

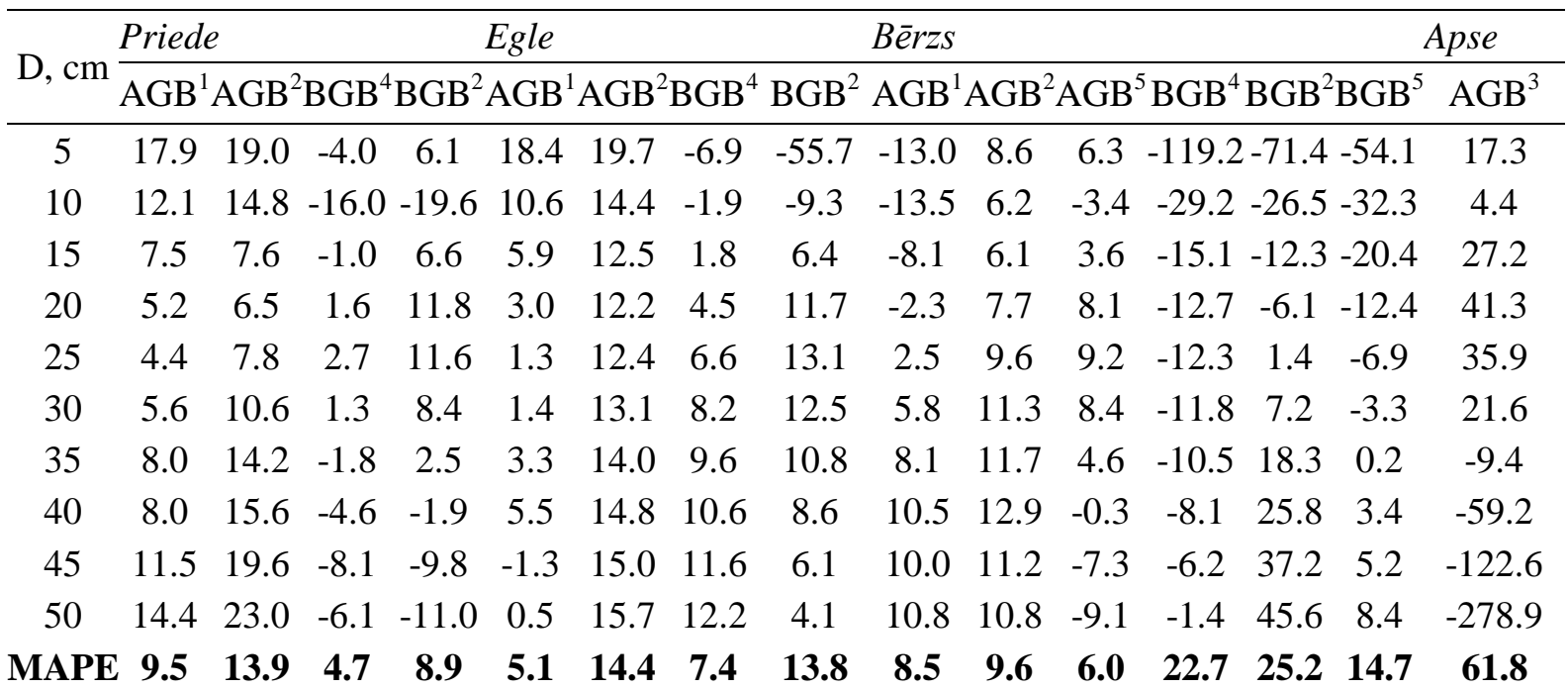

${ }^{1}$ Marklund (1988), ${ }^{2}$ Repola $(2008,2009),{ }^{3}$ Johansson (2000, 2002), ${ }^{4}$ Peterson \& Stahl (2006), ${ }^{5}$ Smith (2014, 2016). Negatīva zīme norāda uz biomasas pārvērtēšanu salīdzinot ar mūsu vienādojumu. MAPE - vidējā absolūtā kḷūda, D - krūšaugstuma caurmērs, AGB - kopējā virszemes biomasa, BGB - kopējā celma/sakṇu biomasa. 

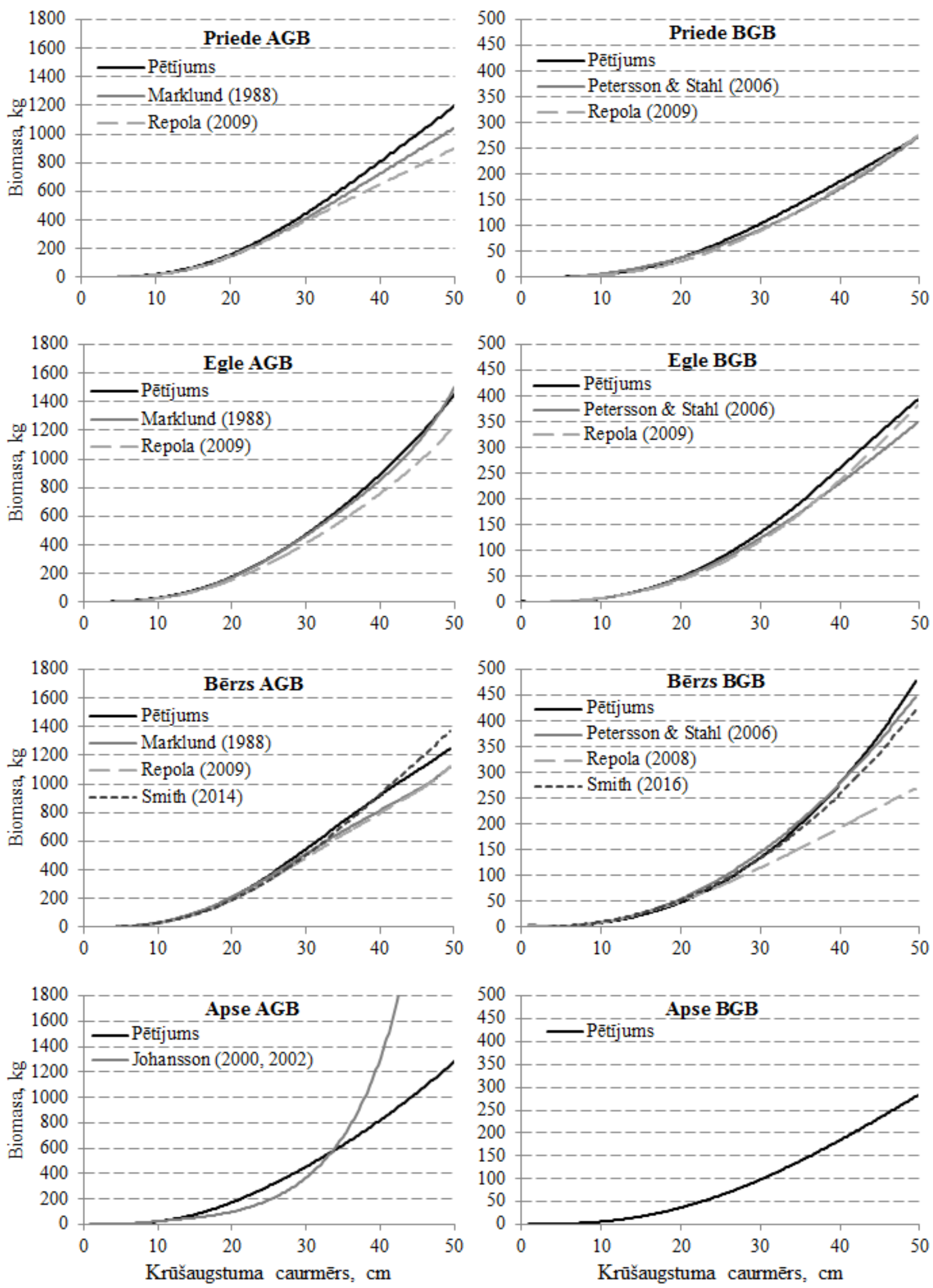

\subsection{4. att. Sagaidāmā virszemes (AGB) un celma/sakṇu (BGB) biomasa atkarībā no pielietotā vienādojuma}

Pētījumā rekomendētie vienādojumi salīdzināti ar vienādojumiem no Baltijas jūras reǵiona 
Darba ietvaros analizēto citu valstu AGB un BGB vienādojumu prognozēšanas precizitāte Latvijas apstākḷlos ir atkarīga ne tikai no pielietotā vienādojuma, bet arī no vidējā koka caurmēra (3.5. tabula). Vienādojumi noteiktās caurmēra grupās biomasu var prognozēt precīzāk vai mazāk precīzi. Viskorektāk citu valstu vienādojumi atspogulıo biomasas izmaiņas diametru grupās no $15-35 \mathrm{~cm}$. Mazu un lielu dimensiju kokiem biomasas aprēķini vidēji atšķiras vairāk nekā par 10\%, salīdzinot ar mūsu pêtījumā izstrādātajiem vienādojumiem, kas daļēji izskaidrojams ar mazāku konkrēto dimensiju paraugkoku skaitu citu valstu pētījumos.

Pētījumā izstrādātie priedes, egles un bērza AGB un BGB vienādojumi salīdzināti ar konkrētajiem citu valstu vienādojumiem (3.14. attēls), kuriem ir identiska celma augstuma definīcija kā mūsu pētījumā. Izņēmums ir apses biomasas vienādojumi, kur celma augstums definēts $10 \mathrm{~cm}$ no zemes virskārtas (Johansson, 2002). Atšķirīga celma augstuma definīcija varētu būt viens no iemesliem, kāpēc apses AGB biomasa pēc Johansson (2000, 2002) vienādojumiem lielākajiem kokiem tiek stipri pārvērtēta, salīdzinot ar mūsu izstrādāto vienādojumu. Piemēram, $30 \mathrm{~m}$ garai apsei mūsu pētījumā celma augstums no zemes virskārtas būs $30 \mathrm{~cm}$, kura masa ieskaitīta BGB ar pieņēmumu, ka pēc koka nozāgeéšanas aptuveni šāda stumbra daļa kopā ar saknēm paliek mežā satrūdēšanai. Savukārt Johansson metodika pie identiska apses garuma tikai stumbra apakšejos $10 \mathrm{~cm}$ no zemes virskārtas ieskaita BGB, bet pārējo celma daļu - AGB frakcijā. Turklāt Johansson apses vienādojumi kā vien̄̄go vienādojumu argumentu izmanto $\mathrm{D}$, kas padara vienādojumus mazāk jutīgus pret koku H izmaiņām dažādu augšanas apstākḷu ietekmes rezultātā. Uz koku D balstīti vienādojumi ir piemēroti biomasas aprēķināšanai kokiem ar identisku $\mathrm{D} / \mathrm{H}$ attiecību kā ievāktajam empīriskajam materiālam.

Analizējot bērza BGB vienādojumu prognozēšanas precizitāti atkarībā no pielietotā vienādojuma, vien̄̄gi Repola (2008) vienādojumam raksturīga ievērojama novirze, palielinoties koka vidējam D. Tas daļēji varētu būt skaidrojams ar pētîjumu metodologiskajām atšķirībām, jo Repolas pētījumā saknes izraktas līdz $10 \mathrm{~mm}$ diametram, bet pārējos pētījumos koku saknes atraktas rūpīgāk - līdz $2 \mathrm{~mm}$ diametram. Interesanti, ka eglei un priedei dažādu vienādojumu BGB aprēksini ir diezgan līdzīgi, neskatoties uz iepriekšminētajām atšķirīibām empīriskā materiāla ievākšanas metodēs. Mūsu novērojumi atbalsta Smith et al. (2016) secinājumu, ka biomasas vienādojumu geogrāfiska ekstrapolācija rada kḷūdainus biomasas aprēķinus. Daudzi zinātnieki ir pētījuši AGB un BGB izmaiņas atkarībā no dažādiem faktoriem secinot, ka koku biomasa ir atkarīga no ǵeogrāfiskā platuma un garuma, veǵetācijas zonas, ūdens deficìts, gada vidējās temperatūras un citiem faktoriem (Berninger et al., 1995; Stegen et al., 2011; Wirth et al., 2004). Koku augšanas apstākḷi Zviedrijas dienvidos ir diezgan līdzīgi augšanas apstākḷiem Latvijā un pēc teritoriālā novietojuma ietilpst Eiropas hemiboreālā mežu joslā (Ahti et al., 1968; EEA, 2007). Šajā sakarā viegli ir izskaidrojams, kāpēc Zviedrijā izstrādātie (Marklund, 1988; Petersson \& Stahl, 2006) priedes, egles un bērza biomasas vienādojumi Latvijas apstākḷlos ir precīzāki nekā vienādojumi no Somijas (Repola, 2008, 2009).

Sakarā ar vispārzināmām grūtībām korekti prognozēt sauso zaru biomasu dēl lielām šīs biomasas frakcijas variācijām (Zianis et al., 2005), darba ietvaros mēs apvienojām dzīvo un sausu zaru frakcijas kopējā BB. Sauso zaru īpatsvars no BB frakcijas vidēji mūsu pētījumā priedei, eglei, bērzam un apsei bija attiecīgi $13.2 \%, 6.7 \%, 4.3 \%$ un $17.1 \%$. Pētījumā netika novērota būtiska bērza sauso zaru īpatsvara korelācija ar koka parametriem D vai $\mathrm{H}$ (3.6. tabula), līdz ar to var secināt, ka mainoties koka dimensijām, sauso zaru biomasas frakcijas īpatsvars bērzam gandrīz nemainās. Savukārt pārējām koku sugām, lai gan korelācija ir vāja līdz vidēji stipra, tā ir statistiski būtiska $(p<0.05)$. Visciešāk ar koka parametriem D un $\mathrm{H}$ pozitīvi korelē egles sauso zaru biomasas īpatsvars. Mūsu pētîjumā atsevišķām eglēm sauso zaru īpatsvars kopējā BB sasniedza pat 20\%. Izņemot bērzu, pārējām apskatītajām koku sugām vismazākais sauso zaru īpatsvars ir kokiem ar D mazāku par $10 \mathrm{~cm}$. Tā kā bērzs ir izteikti gaismas prasīga koku suga, apakšējo zaru atmiršana bērzam sākās agrāk nekā pārējām 
koku sugām. Turklāt atş̌kirībā no pārējām koku sugām, bērzam korelācija bija negatīva, iezīmējot tendenci samazināties sauso zaru īpatsvaram līdz ar koku D un H pieaugumu.

3.6. tabula

Sauso zaru īpatsvara kopējā zaru biomasā (BB) korelācija ar koku krūšaugstuma diametru (D) un augstumu (H)

\begin{tabular}{ccccccccc}
\hline & \multicolumn{2}{c}{ Priede } & \multicolumn{2}{c}{ Egle } & \multicolumn{2}{c}{ Bērzs } & \multicolumn{2}{c}{ Apse } \\
\cline { 2 - 9 } & $\mathrm{D}$ & $\mathrm{H}$ & $\mathrm{D}$ & $\mathrm{H}$ & $\mathrm{D}$ & $\mathrm{H}$ & $\mathrm{D}$ & $\mathrm{H}$ \\
\hline $\mathrm{R}^{*}$ & 0.30 & 0.29 & 0.62 & 0.66 & -0.12 & -0.18 & 0.46 & 0.53 \\
p verttība & 0.002 & 0.003 & 0.000 & 0.000 & 0.234 & 0.063 & 0.000 & 0.000 \\
\hline
\end{tabular}

*Spīrmena rangu korelācijas koeficients

Mūsu pētījumā aprēķinātās sauso zaru īpatsvara vērtības ir l̦oti līdzīgas tām, kuras aprēksinātas pēc Marklund (1988) vienādojumiem, attiecīgi priedei - $13.6 \%$, eglei $-7.6 \%$ un bērzam - 4.6\%. Turpretī Repola $(2008,2009)$ biomasas vienādojumi priedei, eglei un bērzam prognozē nedaudz lielākas sauso zaru īpatsvara vidējās vērtības, attiecīgi 15.1\%, 11.5\% un 7.1\%. Iepriekšminētais liecina, ka nepieciešamības gadījumā sauso zaru biomasu priedei un eglei ir iespējams aprēķināt pēc Zviedrijā izstrādātajiem vienādojumiem, jo Latvijas apstākḷos vienādojumu prognozes būs precīzākas nekā vidējās īpatsvara vērtības, iegūtas no kopējās zaru biomasas.

Vienādojumu atlikumu sadalījuma struktūra (3.11. attēls, 3.12. attēls, 3.13. attēls) apstiprināja, ka pētījumā rekomendētie vienādojumi ir pielietojami koku biomasas aprēksiniem plašā D amplitūdā un, balstoties un ievāktā empīriskā materiāla daudzveidību, - arī dažāos koku augšanas apstākļos. Tomēr ir apstākḷi, kur darba ietvaros izstrādāto vienādojumu precizitāte ir neskaidra un nepārbaudīta. Izstrādāto vienādojumu piemērotība joprojām nav pārbaudīta nomākto un atmirstošo koku biomasas aprēķiniem, jo tie pētījumā netika iekḷauti kā paraugkoki. Nomāktiem un atmirstošiem kokiem savstarpējās konkurences rezultātā ir izveidojies mazāks zaḷais vainags nekā pārējai kokaudzei un prognozējams, ka rekomendētie biomasas vienādojumi pārvērtēs to kopējo biomasu, jo īpaši zaru biomasu. Tāpat paraugkoki netika izvēlēti vietās ar augstu ūdens līmeni slapjās kūdras augsnēs, jo šādās vietās bija apgrūtināta kvalitatīva datu ievākšana. Minētie ierobežojumi jāpatur prātā, aprēķinot BGB biomasu kūdras augsnēs, jo šādās augsnēs augušu koku sakṇu biomasa parasti ir lielāka nekā minerālaugsnēs (Hakkila, 1972). Apsaimniekotu mežaudžu biomasas prognožu vienādojumi parasti dod kḷūdainas prognozes neapsaimniekotās un pārbiezinātās jaunaudzēs (Repola \& Ulvcrona, 2014). Tāpēc būtu nepieciešami turpmāki pētîjumi, lai novērtētu darba ietvaros izstrādāto vienādojumu piemērotību arī šādos apstāklıos.

Neraugoties uz empīiskā materiāla lietošanas ierobežojumiem, mūsu pētījumā izstrādāto biomasas vienādojumu salīdzināšana ar līdzịgiem vienādojumiem no Baltijas jūras reǵiona (3.14. attēls) apstiprināja, ka rekomendētie vienādojumi ticami prognozē biomasu arī lielāku dimensiju kokiem nekā uzmērītajiem paraugkokiem. Darba ietvaros lielākais nozāğêtā paraugkoka D priedei, eglei un bērzam bija robežās no $36.3-45.2 \mathrm{~cm}$ (2.2. tabula), bet AGB un BGB vienādojumu validēšanā izmantoto koku maksimālais D bija $57.3 \mathrm{~cm}$.

\subsection{Latvijas kokaudzēs uzkrātais ogleklis atbilstoši Latvijas meža resursu monitoringa datiem}

Latvijas kokaudžu oglekḷa uzkrājuma raksturošanai izmantoti MRM 2012.-2016. gada rezultāti, ietverot II cikla pēdējos divu gadu uzmērījumus un III cikla pirmo trīs gadu uzmērījumus. Izvēlētais aprēķinu periods raksturo Latvijas kokaudžu oglekḷa apjomu uz 
2016. gadu un identisks aprēķinu periods ir atspogulots arī 2018. gada Latvijas veidotajā pārskatā par SEG emisijām un oglekļa uzkrājumiem valstī. Aprēķinos izmantoti pētījumā rekomendētie individuālu koku biomasas vienādojumi piemērojot tos katram MRM parauglaukumos uzmērītajam kokam atbilstoši sugai. 2018. gada Latvijas veidotajā pārskatā par oglekḷa uzkrājumiem valstī kokaudzēs uzkrātais ogleklis rēķināts no MRM parauglaukumu krājas, koksnes reducētā blīvuma un dažādiem biomasas pārrēķinu koeficientiem (UNFCCC, 2018). Kokaudžu oglekḷa uzkrājumu aprēķinos izmantoti tikai MRM parauglaukumu dati par zemes kategorijām (pēc MRM klasifikācijas kods 10-14, 62, 64) atbilstoši UNFCCC un Kioto protokola definētajai meža zemes definīcijai. MRM ierīkotajos pastāvīgajos parauglaukumos uzmērīti visi koki sākot no $2.1 \mathrm{~cm}$ diametra. Tā kā biomasas vienādojumi pētījumā izstrādāti tikai četrām Latvijā izplatītākajām koku sugām, pārējām sugām vienādojumi piemēroti atbilstoši 3.7. tabulai.

3.7. tabula

Mežu resursu monitoringa (MRM) datubāzē koku sugām piemērotie biomasas vienādojumi Latvijas kokaudžu oglekḷa aprēḳiniem

\begin{tabular}{cccc}
\hline Suga & Sugu grupa & Sugas kods & Piemērotais vienādojums \\
\hline priede & skujkoks & 1 & priedes \\
egle & skujkoks & 3 & egles \\
bērzs & lapkoks & 4 & bērza \\
melnalksnis & lapkoks & 6 & apses \\
apse & lapkoks & 8 & apses \\
baltalksnis & lapkoks & 9 & apses \\
ozols & lapkoks & 10 & bērza \\
osis & lapkoks & 11 & bērza \\
liepa & lapkoks & 12 & bērza \\
lapegle & skujkoks & 13 & egles \\
citas priedes & skujkoks & 14 & priedes \\
citas egles & skujkoks & 15 & egles \\
goba, vīksna & lapkoks & 16 & bērza \\
dižskābardis & lapkoks & 17 & bērza \\
skābardis & lapkoks & 18 & bērza \\
papele & lapkoks & 19 & apses \\
vītols & lapkoks & 20 & apses \\
blīgzna & lapkoks & 21 & apses \\
ciedru priede & skujkoks & 22 & priedes \\
baltegle & skujkoks & 23 & egles \\
kḷava & lapkoks & 24 & bērza \\
mežābele & lapkoks & 51 & bērza \\
ksirsis & lapkoks & 56 & bērza \\
citas koku un krūmu sugas & lapkoks & - & apses \\
\hline & & & \\
\hline
\end{tabular}

Pētījumā izstrādātie biomasas vienādojumi attiecināmi uz $85.5 \%$ Latvijas kokaudžu krājas, kurā priedes īpatsvars $-33.0 \%$, egles $-19.5 \%$, bērza $-23.7 \%$, bet apses $-9.3 \%$. No pārējo koku sugu krājas īpatsvara Latvijas mežos kas ir 14.5\%, lielāko daļu jeb 12.2\% aizṇem alkšņu gints koku sugas baltalksnis (6.2\%) un melnalksnis (6.0\%). Tā kā abām alkšņu gints sugām netika atrasti oglekḷa uzkrājumu aprēķiniem piemēroti biomasas vienādojumi, tiem 
piemēroti pētījumā izstrādātie apses vienādojumi. Apses vienādojumi abām koku sugām piemēroti, balstoties uz koksnes reducēto blīvumu, kurš alkšņiem pēc literatūrā atrodamās informācijas un mūsu pētījuma datiem vairāk atbilst apsei nekā bērzam (3.2. tabula). Zviedrijā analizējot 24 baltalkšņa un 31 melnalkšņa dabiskas izcelsmes kokaudzes aprēķinātais vidējais reducētais koksnes blīvums baltalksnim bija $359 \mathrm{~kg} \mathrm{~m}^{-3}$, bet melnalksnim - $427 \mathrm{~kg} \mathrm{~m}^{-3}$ (Johansson, 2005). No iepriekšminētā pētījuma iegūtais abu alkšņu vidējais svērtais blīvums $\left(409 \mathrm{~kg} \mathrm{~m}^{-3}\right)$ pēc to aizṇemtās krājas îpatsvara Latvijā ir ļoti tuvs blīvumam $\left(399.4 \mathrm{~kg} \mathrm{~m}^{-3}\right)$, kāds ir konstatēts apsei mūsu pētījumā. Citā pētījumā atspoguḷotas Ziemel̦eiropu un Baltijas valstis raksturojošas reducētā blīvuma vērtības, kuras baltalksnim $\left(360 \mathrm{~kg} \mathrm{~m}^{-3}\right)$ un melnalksnim $\left(370 \mathrm{~kg} \mathrm{~m}^{-3}\right)$ arī norādītas kā tuvākas apsei $\left(380 \mathrm{~kg} \mathrm{~m}^{-3}\right)$ nevis bērza $\left(480 \mathrm{~kg} \mathrm{~m}^{-3}\right)$ blīvuma vērtībām (Rytter et al., 2016). Arī pērējām pētījumā neapskatītajām koku sugām (3.7. tabula) tāpat kā alkšniem, izstrādātie biomasas vienādojumi piemēroti pēc tuvākām reducētā blīvuma vērtībām, kuras pārējām sugām atrodamas Dryad datubāzē (Zanne et al., 2009).

Pētījumā aprēķināts, ka visas Latvijas kokaudžu oglekḷa uzkrājuma raksturošanai, vidējais svērtais oglekḷa saturs koku biomasā ir $49.9 \% \pm 0.006 \%$, kurš aprēķināts pēc rekomendētajām skujkoku un lapkoku oglekḷa satura vērtībām mērenās un boreālās joslas mežiem (Thomas \& Martin, 2012) un skujkoku un lapkoku biomasas ipatsvara Latvijas mežos. Pētījumā lietotais oglekḷa saturs dzīvajā biomasā skujkokiem ir 50.8\%, bet lapkokiem 48.8\%. Oglekḷa saturs dažādām koka frakcijām (stumbrs, zari, saknes) ir nedaudz atšķirīgs, tomēr, ņemot vērā detalizētu pētījumu trūkumu, visām koka frakcijām piemērota identiska oglekļa satura vērtība atbilstoši sugu grupai pēc 3.7. tabulas.

Pētījumā aprēķinātais Latvijas kokaudžu biomasā uzkrātais ogleklis kopā 2016. gadā ir $238.1 \pm 3.5$ milj.t (3.15. attēls). Lielākais īpatsvars (79\% jeb 187.8 milj.t) no tā ir akumulēts kokaugu virszemes daḷā, kamēr celmos un saknēs akumulēts apmēram 50.3 milj.t oglekḷa. Latvijas sastādītajā ziņojumā par oglekḷa piesaisti valstī atbilstoši UNFCCC vadlīnijām, kokaudzēs uzkrātais ogleklis identiskā aprēķina periodā ir 237.0 milj.t., kurš, neskatoties uz promocijas darba un pašreiz spēkā esošās metodikas atšķirībām, ir ļoti tuvi mūsu aprēķiniem. Lielākās abu aprēķinu metožu atšķirības ir skaidrojamas ar atşķirīgajiem pieņēmumiem par oglekḷa saturu dzīvajā biomasā. Mūsu pētījumā pielietotais vidējais svērtais oglekḷa saturs dzīvajā biomasā ir 49.9\%, kamēr pašreiz spēkā esošajā metodikā tas ir 52.1\%, tādā veidā palielinot kopējos oglekļa uzkrājumus valstī. Piemērojot mūsu aprēķinos dzīvās biomasas oglekḷa saturu ko izmanto līdzšinējā aprēķinu metodika, Latvijas kokaudžu akumulētais ogleḳ̦a apjoms būtu lielāks par 10.5 milj.t jeb $4.2 \%$ un sasniegtu 248.1 milj.t. Tas norāda uz to, ka līdzšinējā aprēķinu metodika nepietiekošā apmērā novērtē kokaudžu biomasu Latvijā.

Salīizinot Latvijā veikto pētījumu rezultātus par oglekḷa saturu priedes, egles, bērza un baltalkšņa biomasas frakcijās (stumbrs, zari un saknes) secināts, ka tas ir bijis robežās no 47.2-51.7\%. Vidējā svērtā oglekḷa satura 52.1\% lietošana nedaudz pārsniedz iepriekš konstatētās vērtības Latvijā, tomēr jāatzīmē, ka pētījumi Latvija veikti galvenokārt šo koku sugu jaunaudzēs un kokaugu stādījumos lauksaimniecībā neizmantotajās zemēs. Par cik šobrīd trūkst informācijas par oglekḷa satura variēšanu dalījumā pa koku sugām un biomasas frakcijām visā hemiboreālajā mežu reǵionā, Latvijas nacionālajā SEG ziņojumā lietotās oglekḷa satura vērtības (50.7-53\% atkarībā no koku sugas) pirms izmantošanas būtu jāverificē un jāapraksta anonīmi recenzētos zinātniskos izdevumos, kas līdz šim nav darīts. Tāpēc, pamatojoties uz citu Eiropas valstu oglekḷa satura pieņēmumiem to aprēķinu metodikās (1.4. tabula) un jaunākajām atziṇām par oglekḷa saturu mērenās joslas un boreālajos mežos (Thomas \& Martin, 2012), esošajā Latvijas aprēksinu metodikā lietoto oglekḷa saturu dzīvajā biomasā būtu ieteicams samazināt uz $48.8 \%$ lapkokiem un $50.8 \%$ skujkokiem. 


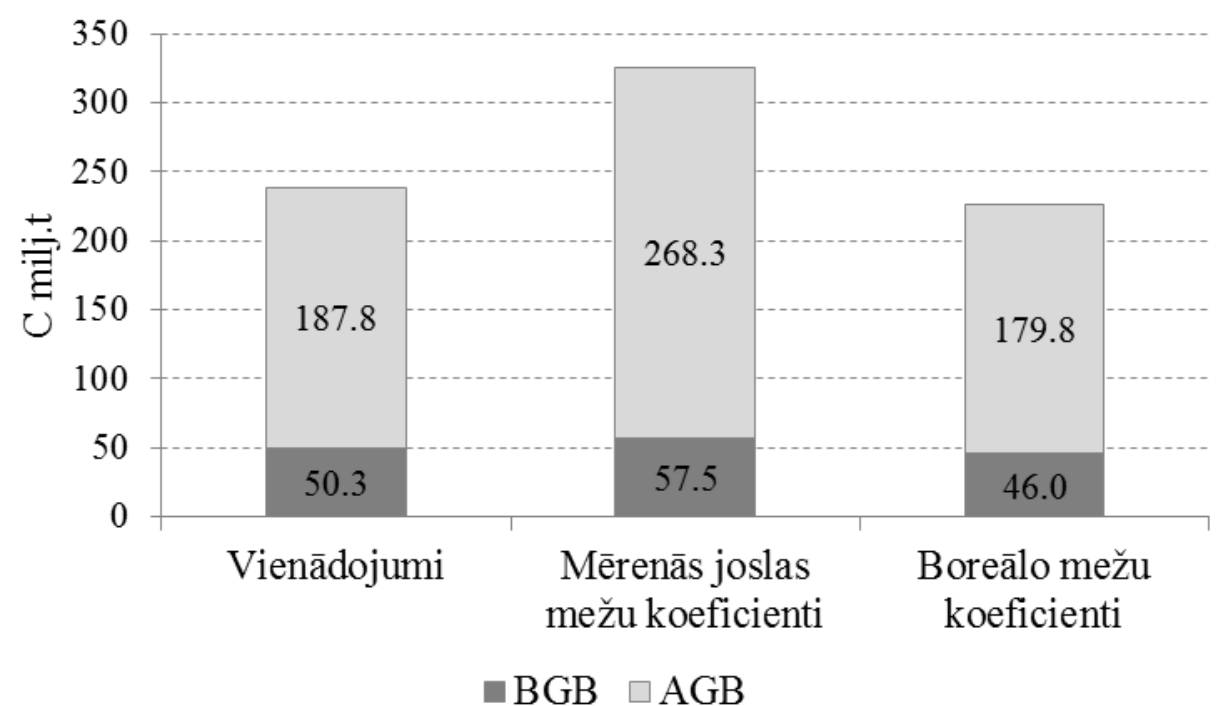

\subsection{5. att. Uzkrātais ogleklis kokaudžu virszemes biomasā (AGB) un celma/sakṇu biomasā (BGB) pielietojot dažādas aprēḳinu metodes}

Daudz neprecīzāki Latvijas kokaudžu oglekḷa aprēķini bija lietojot IPCC vadlīniju (Eggleston et al., 2006) piedāvātos biomasas pārrēķina koeficientus mērenās joslas un boreālajiem mežiem (3.15. attēls). Lai novērtētu IPCC vadlīniju piedāvāto koeficientu ietekmi uz kokaudžu oglekḷa aprēķiniem, visās metodēs piemērots identisks pien̦ēmums par oglekḷa saturu biomasā. Izmantojot mērenās joslas mežu pārrēķinu koeficentus, Latvijas kokaudžu oglekḷa uzkrājumi tiek pārvērtēti par $36.9 \%$ jeb par 87.8 milj.t. Salīdzinot ar pētījumā izstrādātajiem biomasas vienādojumiem, šie Dienvideiropai piemērotie koeficienti krietni vairāk pārvērtē kokaudžu virszemes daḷā akumulēto oglekli (par 42.9\%), bet mazāk kokaudžu celmu un sakṇu oglekḷa apjomus (par 14.4\%). Pretēji ir ar vadlīniju piedāvātajiem boreālo mežu biomasas pārrēksina koeficentiem, kuru izmantošana par 5.2\% jeb 12.3 milj.t samazina kokaudzēs uzkrāto oglekli, salīdzinot ar mūsu pētījumā lietoto aprēķinu metodiku. Piemērojot šos Ziemel̦eiropai paredzētos pārrēķina koeficientus, lielāka kḷūda rodas kokaudžu celma/sakṇu daļas oglekḷa novērtēšanā (- 8.5\%), kamēr uzkrātais ogleklis kokaudžu virszemes biomasā tiek novērtēts nedaudz precīzāk ar kḷūdu - 4.3\%.

IPCC vadlīnijās (Eggleston et al., 2006) pēc teritoriālā novietojuma Latvijai tiek piedāvāti mērenās joslas mežu biomasas aprēķinu un pārrēķinu koeficienti, bet pēc mūsu pētījuma aprēķiniem redzams, ka šo pārrēķinu koeficientu izmantošanu Latvijas apstākḷাos nav piel̦aujama. Promocijas darba izstrādes gaitā, balstoties uz daļēji ievākto empīrisko materiālu, jau 2013. gadā IPCC vadlīniju piedāvātie pārrēķinu koeficienti Latvijai tika koriǵēti, jo koku biomasas mērījumi liecināja par būtiskām vadlīniju piedāvāto pārrēķinu koeficientu neatbilstībām. Nākot klāt jaunam empīriskajam materiālam un 2015. gadā noslēdzoties pētījumam "Mežsaimniecisko darbību ietekme uz siltumnīcefekta gāzu emisijām un $\mathrm{CO}_{2}$ piesaisti" biomasas aprēķina metodika tika koriǵēta vēlreiz. Dažādos aprēķinu etapos izmantoto BEF koriǵēšana līdz šim ir l̦āvusi pakāpeniski uzlabot Latvijas kokaudžu oglekḷa aprēķinu metodiku, izvairoties no būtiska akumulētā oglekļa pārvērtēšanas riska. Minētā iemesla dēḷ nelielās atšķirības Latvijas kokaudžu oglekḷa uzkrājuma aprēķinos starp pētījumā izstrādāto un pašreiz spēkā esošo metodiku ir viegli izskaidrot, jo, gan izstrādātie biomasas vienādojumi, gan IPCC vadlīniju koriǵētās BEF vērtības, balstās uz vienu un to pašu empīrisko materiālu. Ir pierādīts, ka izmantojot individuālu koku biomasas vienādojumus kopā ar MRM datubāzi, iespējams iegūt precīzākas biomasas prognozes nekā biomasu aprēķinot no kopējās krājas ar BEF (Neumann et al., 2016). Līdzīgi kā mūsu veiktajos aprēķinos, arī Zviedrijas pieredze rāda, ka ar atsevišķu koku biomasas vienādojumiem 
aprēķinātā kokaudžu AGB ir vidēji par 5\% lielāka, nekā aprēķināta no kokaudžu krājas datiem (Jalkanen et al., 2005).

Salīdzinot kokaudžu oglekḷa resursus pēc valdošās koku sugas aizṇemtās platības secināts, ka izteikti vairāk tas akumulēts priežu kokaudzēs (3.16. attēls). Tas izskaidrojams ar to, ka priede Latvijā aizṇem vislielākās meža platības, kā arī skujkoku biomasā oglekḷa saturs ir lielāks nekā lapkokos. Darba ietvaros aprēķinātais bērzu, egl̦u un apšu kokaudzēs uzkrātais ogleklis ir attiecīgi par 19.5 milj.t, 29.4 milj.t un 58.7 milj.t mazāks nekā priedei.

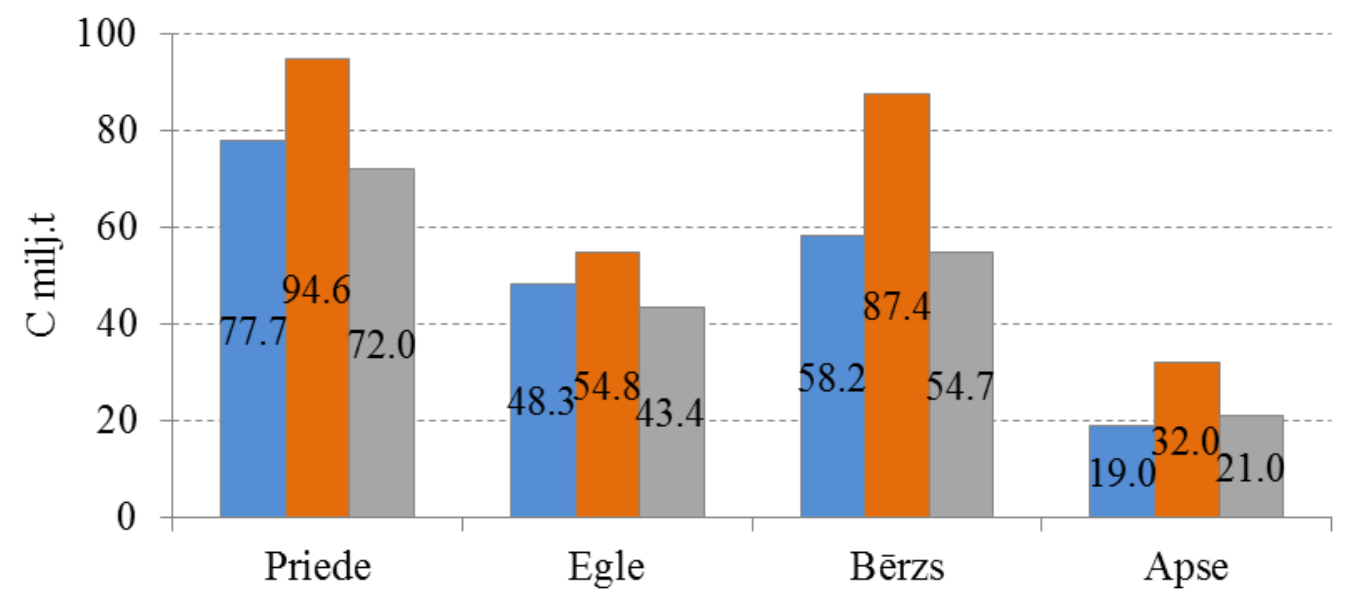

- Vienādojumi $\square$ Mērenās joslas mežu koeficienti $\square$ Boreālo mežu koeficienti

\subsection{6. att. Uzkrātais ogleklis pēc valdošās koku sugas aizṇemtās platības pielietojot dažādas aprēksinu metodes}

Analizējot IPCC vadlīniju rekomendēto mērenās joslas un boreālo mežu BEF ietekmi uz oglekļa aprēķiniem dalījumā pa koku sugām secināts, ka Dienvideiropai paredzētie jeb mērenās joslas mežu koeficienti pārvērtē oglekli visu sugu audzēs. Visvairāk ogleklis tiek pārvērtēts platībās kur dominē lapkoki, bērzu audzēs par 50.2\% un apšu audzēs par $68.6 \%$, bet mazāk priedes $(21.7 \%)$ un egles (13.6\%) audzēs. Savukārt Ziemel̦eiropai paredzētie jeb boreālo mežu pārrēķina koeficienti Latvijas apstākḷos nepietiekamā apmērā novērtē biomasu priedes, egles un bērzu audzēs, attiecīgi uzkrātais ogleklis ir par 7.3\%,10\% un 6\% mazāks salīdzinājumā ar mūsu pētījuma izstrādāto aprēķinu metodiku. Pretēji iepriekšminētajām koku sugām, izmantojot boreālo mežu BEF, apšu kokaudžu uzkrātais ogleklis tiek pārvērtēts par $10.7 \%$, kas varētu būt skaidrojams ar to, ka Ziemel̦eiropā apse kā dominējošā koku suga ir sastopama reti un galvenokārt tā aug tikai piemistrojumā eg̣ı vai bērzu mežos (Heräjärvi, 2009; Rytter et al., 2016). Par cik BEF boreālo mežu reǵionam visām lapkoku sugām ir vienādi, acīmredzot, tie vairāk piemēroti bērza biomasas raksturošanai, kas Ziemel̦eiropā ir izplatītāka koku suga.

No Latvijas kokaudzēs akumulētā oglekḷa lielākais īpatsvars jeb 61\% ir uzkrāts skujkoku biomasā. Priedes un egles biomasā kopā akumulēts apmēram 145.5 milj.t oglekḷa, kurš gandrīz līdzịgi sadalīts pa abām iepriekšminētajām koku sugām (3.17. attēls). Lapkoku biomasā akumulēts apmēram 93.1 milj.t oglekḷa, tajā skaitā bērzos 54.3 milj.t un apsēs 13.6 milj.t. Pretēji pārējām koku sugām, egles biomasā krietni lielāks oglekḷa daudzums akumulēts nestumbra biomasas frakcijās (zari un saknes), kurās uzkrāts apmēram puse jeb 49\% no egl̦u biomasā uzkrātā apjoma. Priedes, egles un bērza nestumbra biomasas frakcijās atkarībā no sugas akumulēts vien 33-35\% no oglekḷa apjoma. Egles nestumbra frakciju biomasas īpatsvars dalıejii ir izskaidrojams ar to, ka eglei kā èncietīgai koku sugai noēnoto zaru atmiršanas process ir lēnāks kā pārējām koku sugām, līdz ar to proporcionāli stumbram, tās zaru biomasa ir lielāka. 


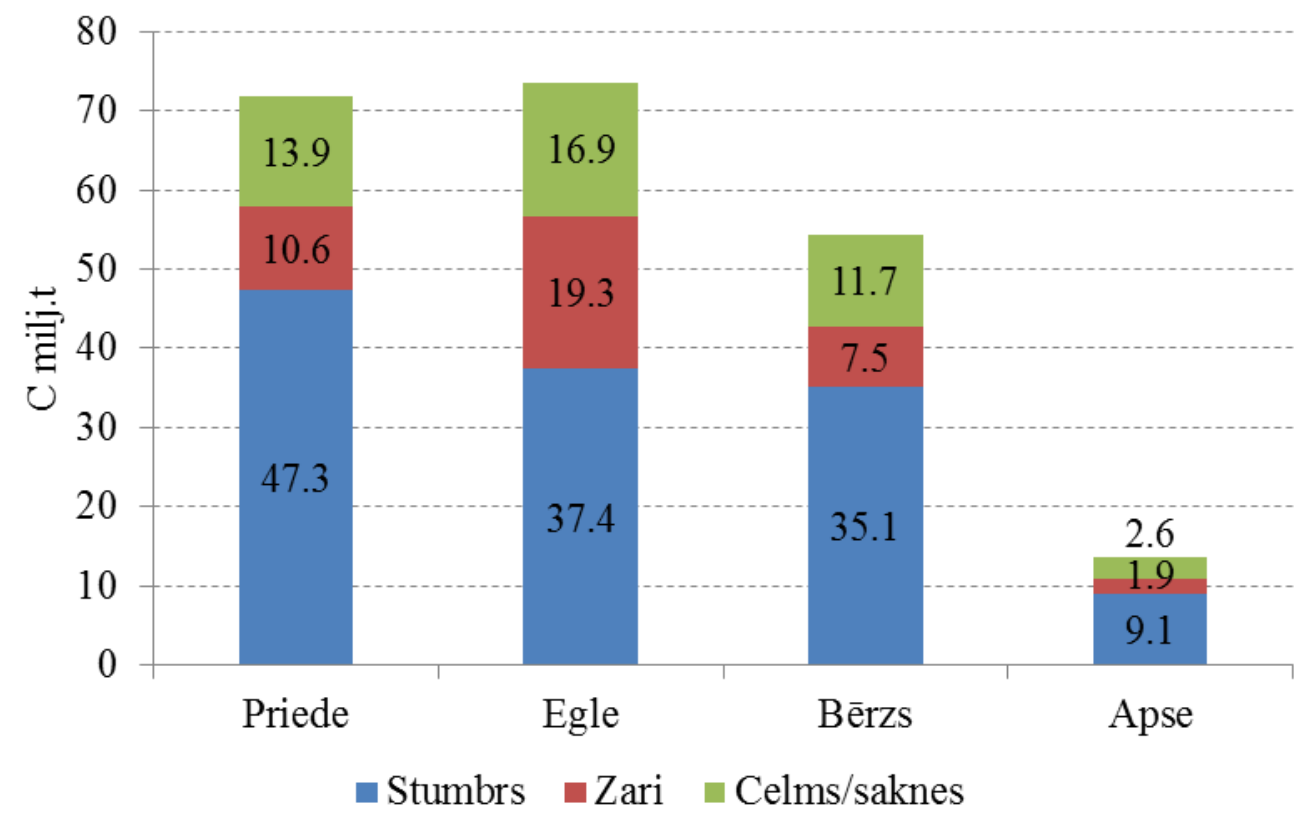

\subsection{7. att. Koku stumbrā, zaros un celmos/saknēs uzkrātais ogleklis atkarībā no sugas}

Meklējot izskaidrojumu, kāpēc, novērtējot Latvijas kokaudzēs uzkrāto oglekli pēc valdošās koku sugas krājas datiem tas tiek novērtēts mazāk nekā pēc atsevišķu koku biomasas vienādojumiem, pētījumā analizētas 3.16. attēls un 3.17. attēls redzamās atšķirības dalījumā pa koku sugām. Salīdzinot uzkrāto oglekli egles biomasā abos iepriekšminētos attēlos, redzams, ka reālais oglekḷa uzkrājums eglēs ir par 25.3 milj.t lielāks nekā novērtēts pēc egḷu kokaudžu aizṇemtās platības. Tas izskaidrojams ar to, ka egle bieži veido otro stāvu vai mistraudzi audzēs, kur dominējošā suga pēc krājas datiem ir cita. Minētajā situācijā egles biomasa tiek pieskaitîta meža nogabalā dominējošai koku sugai. Aprēķinot biomasu pēc valdošās koku sugas krājas datiem, šo faktoru aprēķinos iekļaut nav iespējams, ja vien netiek novērtēta katras koku sugas krāja atsevišķi. Pētījumā no visiem MRM uzmērītajiem parauglaukumiem aprēķināts, ka Latvijā mežos vidēji viens egles stumbra $\mathrm{m}^{3}$ visās biomasas frakcijās kopā ir piesaistījis 1.47 t CO $\mathrm{CO}_{2}$, kas ir līdzvērtīgs 0.40 t oglekḷa. Pārējām koku sugām kopējā $\mathrm{CO}_{2}$ un oglekḷa piesaiste uz stumbra $\mathrm{m}^{3}$ ir mazāka nekā eglei, attiecīgi priedei tā ir 1.24 un 0.34 t, bērzam -1.36 un $0.37 \mathrm{t}$, apsei -1.00 un 0.27 t. Tà kā egle uz m ${ }^{-3}$ koksnes uzkrāj visvairāk oglekḷa tad egles krājas pielīdzināšana valdošai koku sugai nepietiekamā apmērā novērtēs no kopējās krājas datiem rēķinātos oglekḷa apjomus. Vislielākā novirzei no reālās kokaudžu $\mathrm{CO}_{2}$ piesaistes, ir mīksto lapkoku (apses, iespējams arī baltalkšņu) kokaudzēs, jo $\mathrm{CO}_{2}$ piesaistes starpība uz stumbra $\mathrm{m}^{3}$ starp egli un mīksto lapkoku sugām ir vislielākā. Iepriekšminēto apstiprina reālais apsēs uzkrātais oglekḷa apjoms (3.17. attēls), kurš ir gandrīz par 40\% mazāks nekā apšu kokaudžu oglekḷa apjoms kur tā ir valdošā suga (3.16. attēls).

Vidēji Latvijas kokaudzēs akumulēts $67.4 \pm 0.6 \mathrm{tha}^{-1}$ oglekḷa. Latvijas kokaudzēs uzkrātais ogleklis ir lielāks salīdzinājumā ar vidējo rādītāju Eiropas boreālajos mežos (54.6 t ha $\left.{ }^{-1}\right)$, bet mazāks salīdzinājumā ar vidējo rādītāju $\left(76 \mathrm{tha}^{-1}\right)$ Eiropas mērenās joslas skujkoku mežos (Thurner et al., 2014). Salīdzinot kokaudžu oglekḷa resursus uz platības vienību dalījumā pēc valdošās koku sugas, secināts, ka visvairāk ogleklis uzkrāts priedes audzēs, vidēji 89.2 t ha $^{-1}$. Egles, bērza un apses kokaudzēs uzkrātā oglekḷa apjomi ir nedaudz mazāki kā priedei, attiecīgi $79.3 \mathrm{tha}^{-1}, 62.9 \mathrm{tha}^{-1}$ un $69.1 \mathrm{tha}^{-1}$. Zināmā mērā tas ir likumsakarīgi, jo priedes kokaudžu vidējais vecums Latvijā ir 73 gadi, kas ir daudz vairāk nekā egles, bērza un apses kokaudzēm, kuru vidējais vecums ir attiecīgi 46, 39 un 31 gadi. Tā 
kā kokaudzēs uzkrātā oglekḷa apjoms ir atkarīgs no audzes vecuma (Kolari et al., 2004; Law et al., 2003), tad, analizējot uzkrāto oglekli platības vienībā, MRM parauglaukumu dati sadalīti pa desmitgadēm atkarībā no valdošās sugas vecuma (3.18. attēls).

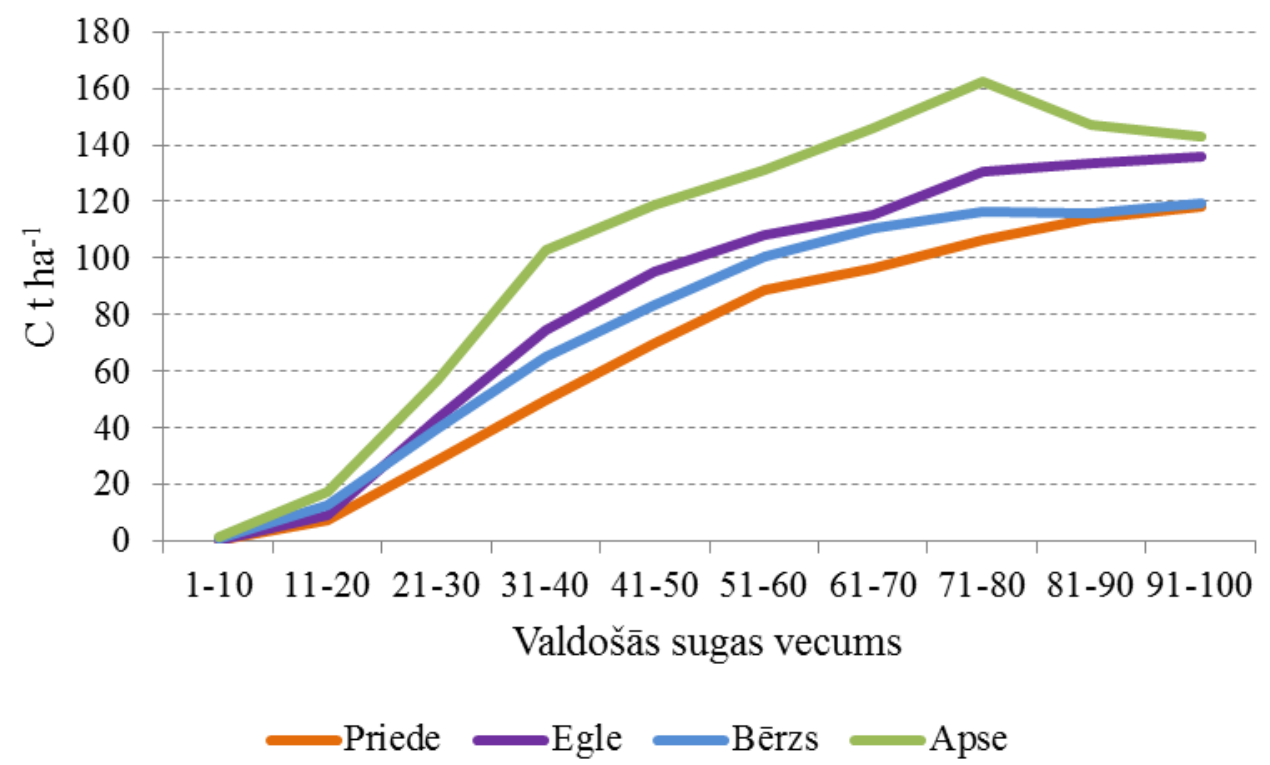

\subsection{8. att. Dažāda vecuma audzēs uzkrātais ogleklis pēc valdošās koku sugas}

No MRM parauglaukumu datiem secināms, ka uz platības vien̄ibu pie identiska kokaudžu vecuma visvairāk ogleklis akumulēts apses audzēs. Tas izskaidrojams ar to, ka apse, salīdzinot ar priedi, egli un bērzu, ir ātraudzīgāka koku suga un Latvijāa aug galvenokārt auglīgās minerālaugsnēs. Koku augšanas apstākḷiem ir liela ietekme uz oglekḷa piesaisti. Piemēram, kopējais uzkrātais oglekḷa apjoms 60 - 80 gadus vecu priežu audžu biomasā vidēji damaksn̄̄ ir 140 t ha $^{-1}$, bet niedrājāâ, kur kokaudžu produktivitāte ir zema, uzkrātais oglekḷa apjoms ir krietni mazāks - $80 \mathrm{t} \mathrm{ha}^{-1}$ (Jansons, 2017). Vislielākais oglekḷa uzkrāšanās un $\mathrm{CO}_{2}$ piesaistes temps ir 10-40 gadus vecās apses, egles un bērzu audzēs un 10-60 gadus vecās priežu audzēs (3.18. attēls). Pieaugot koku vecumam, kokaudžu $\mathrm{CO}_{2}$ piesaistes temps nedaudz samazinās, bet joprojām vērtējams kā samērā augsts. Interesanti, ka apšu audzēs intensīva oglekļa uzkrāšanās koku biomasā notiek līdz apmēram 80 gadu vecumam, bet sasniedzot šo gadu slieksni, audzes sāk sabrukt un kḷūst par emisiju avotu. Priedes, egles un bērza audzēs intensīva oglekḷa uzkrāšanās novērojama apmēram līdz 100, 80 un 70 gadu vecumam, kas praktiski sakrīt ar šo koku sugu noteikto galvenās cirtes vecumu Latvijā, bet atšksirībā no apses, iepriekšminēto koku sugu audzes arī pēc tam turpina piesaistīit $\mathrm{CO}_{2}$, tikai oglekḷa uzkrāšanās temps ievērojami krītas. Jansons (2017) savos pētījumos secinājis, ka kopējais uzkrātais oglekḷa apjoms pieaugušu priežu audžu biomasā būtiski neatšķiras no pāraugušās audzēs konstatētā, kas liecina par to, ka pēc ciršanas vecuma sasniegšanas arī parastās priedes audzēs ievērojami samazinās koku $\mathrm{CO}_{2}$ piesaistes temps, tāpat kā eglei un bērzam.

Analizējot pilnu oglekḷa aprites ciklu, zinātnieki ir secinājuši, ka pāraugušas audzes patiesībā kḷūst par oglekḷa emisiju avotu (Goulden et al., 1996; Lindroth, Grelle, \& Moren, 1998), jo to ikgadējā biomasas ražošana samazinās. Ir pierādīts, ka hemiboreālajā regionā, neskatoties uz ikgadējo biomasas pieaugumu, baltalkšnu audzes jau apmēram pēc 35 gadu vecuma sasniegšanas kḷūst par emisiju avotu, kokos uzkrātajam ogleklim nonākot atpakal atmosfērā koksnes atmiršanas, augsnes humifikācijas un heterotropiskās elpošanas rezultātā (Uri et al., 2017). Apšu kokaudžu $\mathrm{CO}_{2}$ piesaistes tempa saglabāšanos līdz 80 gadu vecumam daḹeji iespējams izskaidrot ar lielu citu koku sugu klātbūtni, uz kuru rēķina ogleklis apses 
kokaudzēs turpina uzkrāties. Patiesībā reālais apsēs uzkrātais oglekļa apjoms varētu būt arī mazāks, jo apses kokaudzēs pēc 40 gadu sasniegšanas ievērojami palielinās trupējušo koku īpatsvars, kas ne tikai ietekmē iegūstamo sortimentu iznākumu, bet arī uzkrātā oglekḷa daudzumu.

Raksturojot Latvijas kokaudžu oglekļa uzkrājumus, mūsu pētījuma aprēķinos ir pieņemts, ka koku stumbri ir bez trupes. Reālajā situācijā mežaudzēs tomēr ir trupējuši un dobumaini koki, kas samazina reālos oglekļa apjomus. Pētījumos Latvijā konstatēts, ka egles stumbros, atkarībā no kokaudzes vecuma, trupējušās koksnes īpatsvars no kopējās stumbru krājas ir robežās no 6\% 40 gadu vecumā līdz 16\% 100 gadu vecumā (Arhipova et al., 2011). Valsts pētījumu programmas "Lapu koku audzēšanas un racionālas izmantošanas pamatojums, jauni produkti un tehnologijas” ietvaros 2008. gadā L. Līpiṇa vadībā analizējot 45-70 gadus vecas apšu audzes, konstatēta kodoltrupes sastopamība 78\% koku un noskaidrots, ka trupes aizñemtais tilpums no kopējā stumbra tilpuma var pat pārsniegt 50\%. Līdzīgi secinājumi konstatēti arī pētījumā par Amerikas apses (Populus tremuloides) trupes izplatību, kur trupe novērota $80 \%$ koku 20-50 gadus vecās audzēs un trupes aizñemtais tilpums var sasniegt $40 \%$ no visa stumbra tilpuma (Worrall \& Fairweather, 2009). Trupei iespējamas dažādas attīstības pakāpes, sākot no iekrāsojušās koksnes un beidzot ar pilnībā sadalījušos koksni. Apjomīgā pētījumā Igaunijā noskaidrots, ka koksnes sadalīšanās pakāpe būtiski ietekmē koksnes blīvumu, bet oglekḷa saturs koksnei sadaloties pat nedaudz palielinās (Köster et al., 2015). Iepriekšminētajā pētījumā, salīdzinot svaigas koksnes un tādas kuru paņemot rokās sadalās blīvumu, noskaidrots, ka priedei, eglei un baltalksnim ir vismazākais koksnes blīvuma samazinājums, progresējot sadalīšanās pakāpei. Blīvums satrupējušai koksnei iepriekšminētajām koku sugām bija attiecīgi par 37\%, 30\% un 36\% no svaigas koksnes blīvuma. Pārējām lapkoku sugām (bērzs, melnalksnis, apse), progresējot koksnes sadalīšanās pakāpei, koksnes blīvums samazinājās ievērojami vairāk, saglabājoties attiecīgi tikai $24 \%, 23 \%$ un $16 \%$ no sākotnējā blīvuma. Par cik stumbra biomasa tiek aprēķināta tā tilpumu reizinot ar blīvumu, tad vidējā stumbra blīvuma samazināšanās gadījumā trupes ietekmē kopējais stumbra biomasas un oglekḷa daudzums samazināsies. Pasaulē uz doto brīdi nav veikti pētījumi par oglekḷa zudumiem stumbra trupes dēḷ, tāpēc pētījuma ietvaros un arī sastādot nacionālos ziņojumu par ZIZIMM sektoru valstī atbilstoši UNFCCC vadlīnijām, šādi aprēķini netiek veikti. Iepriekšminētajā pārskatā lielāks uzsvars tiek likts nevis uz kopējiem kokaudžu oglekl̦a uzkrājumiem, bet gan uz uzkrātā oglekļa izmaiņām pa gadiem vai attiecībā pret kādu periodu.

Latvijas kokaudzēs uzkrātā oglekḷa izmaiņu raksturošanai no 2008.-2016. gadam, izmantotas piecgades slīdošās vidējās vērtības. Konkrētā gada oglekḷa uzkrājuma aprēkiniem tiek izmantoti iepriekšējo piecu gadu MRM parauglaukumu uzmērījumi. Lai izveidotu 9 gadus garu datu rindu, uzkrātā oglekḷa raksturošanai izmantoti MRM dati, kuru ievākšanas periods 2008. gada raksturošanai datējams no 2004. līdz 2008. gadam, bet 2016. gada raksturošanai no 2012. līdz 2016. gadam. Katra nākamā gada raksturošanai, piecgades intervāls nobīdīts par vienu gadu uz priekšu. Atspogulıjot kokaudžu oglekḷa uzkrājuma izmaiņas, aprēķinos izmantoti visi MRM parauglaukumu dati, neatkarīgi no zemes kategorijas (iepriekš kategorijas tika atlasītas atbilstoši UNFCCC un Kioto protokola prasībām), kuros reğistrēti augoši koki.

No MRM datiem secināms, ka Latvijas kokaudzēs uzkrātais ogleklis pēdējo desmit gadu laikā ir palielinājies. Par atskaites punktu pieņemot 2008. gadu, valstī kokaudzēs uzkrātais oglekḷa apjoms ir palielinājies apmēram par 8 milj.t, no 233.1-241.2 milj.t (3.19. attēls). Salīdzinot MRM 1. un 2. pilna cikla rezultātus, secināms, ka valsts oglekḷa uzkrājuma pieaugums nav izskaidrojams tikai vien ar meža platību pieaugumu valstī, jo arī uz platības vien̄ibu akumulētā oglekḷa apjoms ir palielinājies. Pēc MRM 1. cikla ietvaros uzmērītajiem parauglaukumiem aprēķināts, ka kokaudzēs vidēji akumulēts $65.8 \pm 0.6 \mathrm{t} \mathrm{ha}^{-1}$ oglekļa, bet pēc 5 gadiem, atkārtoti pārmērot tos pašus parauglaukumus, aprēķināts, ka vidējais oglekḷa uzkrājums ir palielinājies līdz $67.1 \pm 0.6 \mathrm{t} \mathrm{ha}^{-1}$. Daḷēji oglekḷa uzkrājuma 
pieaugums varētu būt saistîts ar vidējā vecuma pieaugumu, kurš identiskā aprēķinu periodā ir nedaudz pieaudzis no $43.9 \pm 0.3$ līdz $44.2 \pm 0.3$ gadiem. Tomēr, vērtējot vidējā vecuma izmaiṇu tendences pēc piecgades slīdošā vidējā vērtībām, vidējam vecumam tomēr ir tendence samazināties, bet uzkrātais ogleklis platības vienībā ir konstanti palielinājies.

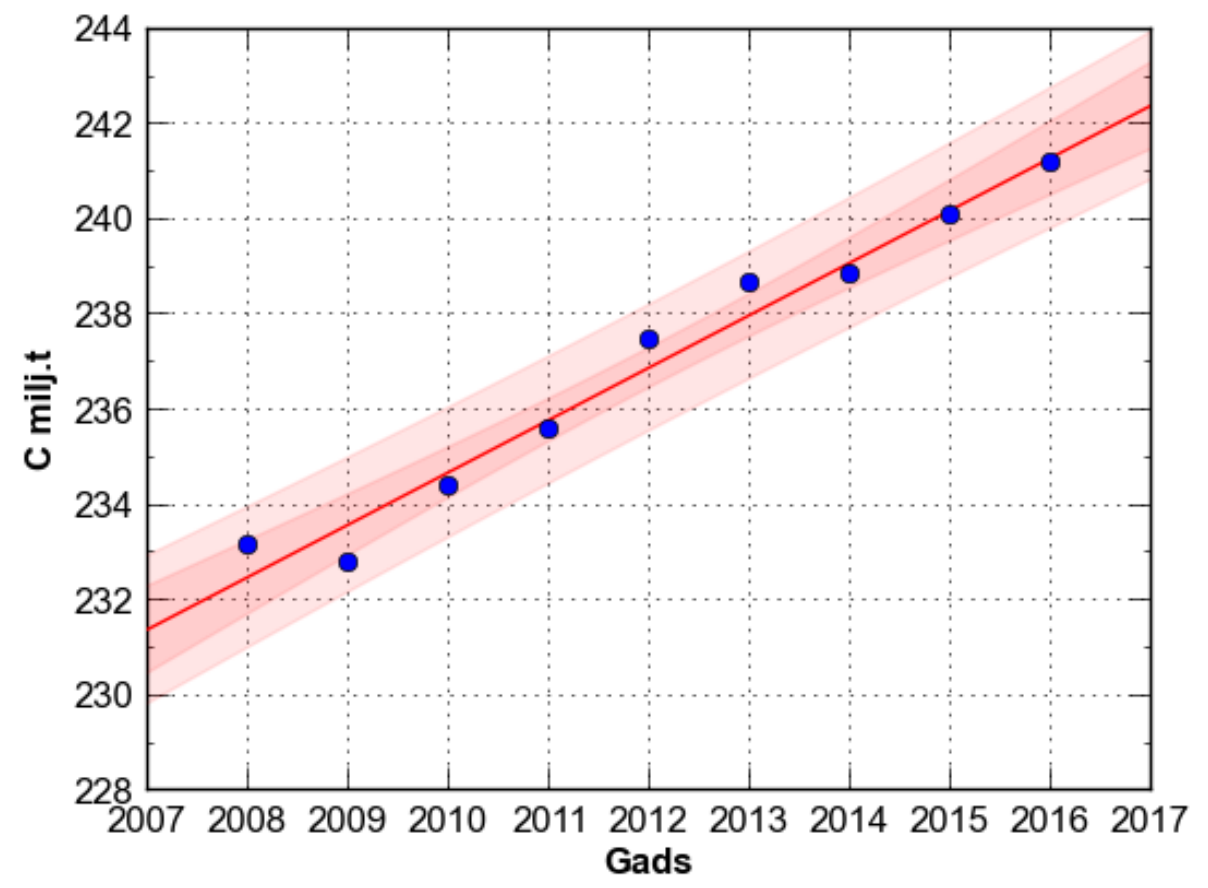

\subsection{9. att. Oglekḷa uzkrājuma vidējo slīdošo vērtību dinamika Latvijā atkarībā no aprēķinu perioda}

Ja Latvijas kokaudzēs uzkrāto oglekli aprēķina atlasot MRM parauglaukumus atbilstoši UNFCCC un Kioto protokola prasībām, uzkrājums ir par 3.1 milj.t mazāks nekā gadījumā, ja aprēķinos izmanto visus MRM parauglaukumus, kuros aug koki. Starpība veidojas jo, piemēram, ceḷa malās, grāvju trasēs, upju krastos, laucēs u.c. zemes vienībās kokaudžu biomasā uzkrātais ogleklis, atbilstoši UNFCCC un Kioto protokola prasībām, tiek ieskaitīts nevis meža zemēs, bet citās zemes kategorijas (apbūve, mitrājs, pl̦ava u.c.). Lai gan aprēķinu starpība ir vien $1.3 \%$, tomēr, aprakstot kokaudzes kā oglekḷa krātuvi, nepieciešams precizēt aprēķina metodi. 


\section{SECINĀJUMI}

1. Priedei un bērzam novērota izteikta stumbra koksnes blīvuma samazināšanās galotnes virzienā. Eglei un apsei koksnes blīvums samazinās līdz 30-40\% relatīvajam koka augstumam, un virzienā uz galotni tālāk pakāpeniski pieaug. Stumbra šķērsgriezumā koku sugām koksnes blīvums palielinās virzienā no serdes uz mizu.

2. Analizētajām koku sugām stumbra vidējais mizas blīvums būtiski atšķiras no vidējā koksnes blīvuma. Vidējā koksnes blīvuma lietošana stumbra biomasas aprēķinos veido vidēji $1.5-4.5 \%$ kḷūdu, atkarībā no koku sugas. Vidējais svērtais stumbra reducētais blīvums priedei ir $380.5 \mathrm{~kg} \mathrm{~m}^{-3}$, eglei $368.9 \mathrm{~kg} \mathrm{~m}^{-3}$ un bērzam $481.7 \mathrm{~kg} \mathrm{~m}^{-3}$ un apsei $399.4 \mathrm{~kg} \mathrm{~m}^{-3}$.

3. Celma/sakṇu un virszemes biomasas attiecība mainās atkarībā no koku dimensijām, tādēl konstantu biomasas pārrēķinu koeficienta pielietošana var radīt sistemātisku kḷūdu oglekḷa uzkrājuma aprēḳinos. Celma, balstsakṇu un sīko sakṇu īpatsvars kopējā visu koku sugu biomasā vidēji ir 20\%. Bērzam un apsei lielāks celma/sakņu biomasas ipatsvars ir jauniem kokiem, bet priedei un eglei pieaugušiem kokiem.

4. Fenoskandijā izstrādāto vienādojumu izmantošana Latvijas apstākḷıs veido 4.7-61.7\% kḷūdu, atkarībā no koku sugas un virszemes vai celma/sakṇu biomasas frakcijas. Tāpēc, kokaudžu oglekḷa uzkrājumu raksturošanai darba ietvaros izstrādāti Latvijas teritorijai piemēroti biomasas aprēķina vienādojumi, kuri lietojami plašā koku dimensiju amplitūdā.

5. Starpvalstu klimata pārmaiņu padomes 2006. gada SEG inventarizācijas vadlīniju piedāvātie mērenās joslas mežu biomasas pārrēḳina koeficienti Latvijas kokaudžu oglekḷa uzkrājumus palielina par 36.9\% jeb par 87.8 milj.t, bet boreālo mežu biomasas pārrēksina koeficientu lietošana par 5.2\% jeb 12.3 milj.t samazina oglekḷa uzkrājuma aprēķinus, salīdzinot ar mūsu pētījumā izstrādātajiem vienādojumiem.

6. Atbilstoši SEG emisiju ziņojumos pielietotajai meža definīcijai, oglekḷa uzkrājumi Latvijas kokaudžu biomasā 2016. gadā bija 238.1 \pm 3.5 milj.t. 


\section{REKOMENDĀCIJAS}

1. Sagatavojot nacionālo SEG inventarizācijas ziņojumu atbilstoši UNFCCC prasībām, Latvijas kokaudžu biomasas aprēķināšanai ieteicams izmantot pētījumā izstrādātos biomasas vienādojumus, jo pašreiz spēkā esošā biomasas aprēķina metodika nepietiekošā apmērā novērtē kokaudžu biomasu Latvijā.

2. Latvijā un visā hemiboreālajā mežu reǵionā trūkst informācijas par oglekḷa satura variēšanu dalījumā pa koku sugām un biomasas frakcijām. Tāpēc, lai izvairītos no oglekḷa uzkrājuma pārvērtēšanas riskiem, Latvijas kokaudžu oglekḷa uzkrājuma aprēksiniem ieteicams lietot mēreno un boreālo mežu vidējās oglekḷa satura vērtības skujkokiem $-50.8 \% \pm 0.6 \%$ un lapkokiem $-48.8 \% \pm 0.6 \%$.

3. Biomasas vienādojumi izstrādāti četrām Latvijā izplatītākajām koku sugām. Pārējo Latvijā sastopamo koku sugu biomasas aprēķiniem ieteicams izmantot pētījumā izstrādātos vienādojumus, piemērojot tos attiecīgi pēc līdzīgākajām stumbra reducētā blīvuma vērtībām skujkokiem un lapkokiem. 


\section{INFORMĀCIJAS AVOTU SARAKSTS}

1. Aboal, J. R., Arévalo, J. R., \& Fernández, Á. (2005). Allometric relationships of different tree species and stand above ground biomass in the Gomera laurel forest (Canary Islands). Flora, 200(3), 264-274. https://doi.org/10.1016/j.flora.2004.11.001

2. Addo-Danso, S. D., Prescott, C. E., \& Smith, A. R. (2016). Methods for estimating root biomass and production in forest and woodland ecosystem carbon studies: A review. Forest Ecology and Management, 359, 332-351. https://doi.org/10.1016/j.foreco.2015.08.015

3. Afif-Khouri, E., Camara-Obregon, A., Canga, E., \& Dieguez-Aranda, I. (2013). Aboveground biomass equations for Pinus radiata D . Don. Forest Systems, 22(3), 408-415.

4. Ahti, T., Hämet-Ahti, L., \& Jalas, J. (1968). Vegetation zones and their sections in northwestern Europe. Annales Botanici Fennici, 3, 169-211.

5. Akaike, H. (1974). A new look at the statistical model identification. IEEE Transactionson Automatic Control, 19(6), 716-723. https://doi.org/10.1109/TAC.1974.1100705

6. Albaugh, T. J., Bergh, J., Lundmark, T., Nilsson, U., Stape, J. L., Allen, H. L., \& Linder, S. (2009). Do biological expansion factors adequately estimate stand-scale aboveground component biomass for Norway spruce? Forest Ecology and Management, 258(12), 2628-2637. https://doi.org/10.1016/j.foreco.2009.09.021

7. Albert, K., Annighöfer, P., Schumacher, J., \& Ammer, C. (2014). Biomass equations for seven different tree species growing in coppice-with-standards forests in Central Germany. Scandinavian Journal of Forest Research, 29(3), 1-12. https://doi.org/10.1080/02827581.2014.910267

8. Alteyrac, J., Zhang, S., Cloutier, A., \& Ruel, J.-C. (2005). Influence of stand density on ring width and wood density at different sampling heights in black spruce (Picea Mariana (Mill.) B.S.P.). Wood and Fiber Science, 37(1), 83-94.

9. Alvarez, E., Duque, A., Saldarriaga, J., Cabrera, K., de las Salas, G., del Valle, I., ... Rodríguez, L. (2012). Tree above-ground biomass allometries for carbon stocks estimation in the natural forests of Colombia. Forest Ecology and Management, 267, 297-308. https://doi.org/10.1016/j.foreco.2011.12.013

10. Andersen, H.-E., Reutebuch, S. E., \& McGaughey, R. J. (2006). A rigorous assessment of tree height measurements obtained using airborne lidar and conventional field methods. Canadian Journal of Remote Sensing, 32(5), 355-366. https://doi.org/10.5589/m06-030

11. Anderson, J. E., Plourde, L. C., Martin, M. E., Braswell, B. H., Smith, M. L., Dubayah, R. O., ... Blair, J. B. (2008). Integrating waveform lidar with hyperspectral imagery for inventory of a northern temperate forest. Remote Sensing of Environment, 112(4), 18561870. https://doi.org/10.1016/j.rse.2007.09.009

12. Arhipova, N., Gaitnieks, T., Donis, J., Stenlid, J., \& Vasaitis, R. (2011). Butt rot incidence, causal fungi, and related yield loss in Picea abies stands of Latvia. Canadian Journal of Forest Research, 41(12), 2337-2345. https://doi.org/10.1139/x11-141

13. Baldasso, M., Birigazzi, L., \& Henry, M. (2012). Tutorial for Tree Allometric Equation Database Development. Rome, Italy.

14. Bārdulis, A. (2013). Sakņu biomasas izpēte sausieņu priežu (pinus sylvestris) jaunaudzēs. Promocijas darbs. Latvijas Lauksaimniecības Universitāte.

15. Bārdulis, A., Daugaviete, M., Lazdiņš, A., Bārdule, A., \& Liepa, I. (2011). Biomasas struktūra un oglekļa uzkrāšanās virszemes un sakṇu biomasā baltalkšņa Alnus incana (L.) Moench. jaunaudzēs lauksaimniecības zemēs. MežzināTne, 23(56), 71-88.

16. Bārdulis, A., Jansons, Ā., Bārdule, A., Zeps, M., \& Lazdiņš, A. (2017). Assessment of Carbon Content in Root Biomass in Scots Pine and Silver Birch Young Stands of Latvia. Baltic Forestry, 23(2), 482-489.

17. Bārdulis, A., Lazdiņa, D., Daugaviete, M., Bārdule, A., Daugavietis, U., \& Rozītis, G. 
(2015). Above ground and below ground biomass in grey alder Alnus incana (L.) Moench. young stands on agricultural land in central part of Latvia. Agronomy Research, 13(2), 277-286.

18. Bartelink, H. H. (1996). Allometric relationships on biomass and needle area of Douglasfir. Forest Ecology and Management, 86(1-3), 193-203. https://doi.org/10.1016/S03781127(96)03783-8

19. Bates, D., Mächler, M., Bolker, B., \& Walker, S. (2015). Fitting linear mixed-effects models using lme4. Journal of Statistical Software, 67(1), 51. https://doi.org/10.18637/jss.v067.i01

20. Batjes, N. H. (2014). Total carbon and nitrogen in the soils of the world. European Journal of Soil Science, 65(1), 10-21. https://doi.org/10.1111/ejss.12114_2

21. Beijere, G., Defais, M., Fišers, M., Flečers, D., Menks, Ē., Jēgers, F., ... Veinendāls, K. (2006). Samaziniet klimata izmaiņas: lietojiet koksni! Rīga: Zạ̄ās mājās.

22. Bergstedt, A., \& Olesen, P. O. (2000). Models for Predicting Dry Matter Content of Norway spruce. Scandinavian Journal of Forest Research, 15, 633-644. https://doi.org/10.1080/02827580050216888

23. Berndes, G., Bird, D. N., \& Cowie, A. L. (2011). Bioenergy, Land Use Change and Climate Change Mitigation. Background Technical Report. International Energy Agency (IEA). Paris.

24. Berninger, F., Nikinmaa, E., Hari, P., Mencuccini, M., \& Grace, J. (1995). Evaporative demand determines branchiness of Scots pine. Oecologia, 102(2), 164-168. https://doi.org/10.1007/BF00333247

25. Blujdea, V. N. B., Pilli, R., Dutca, I., Ciuvat, L., \& Abrudan, I. V. (2012). Allometric biomass equations for young broadleaved trees in plantations in Romania. Forest Ecology and Management, 264, 172-184. https://doi.org/10.1016/j.foreco.2011.09.042

26. Boot-Handford, M. E., Abanades, J. C., Anthony, E. J., Blunt, M. J., Brandani, S., Mac Dowell, N., ... Fennell, P. S. (2014). Carbon capture and storage update. Energy \& Environmental Science, 7(1), 130-189. https://doi.org/10.1039/C3EE42350F

27. Boyd, P. W., Law, C. S., Wong, C. S., Nojiri, Y., Tsuda, A., Levasseur, M., ... Yoshimura, T. (2004). The decline and fate of an iron-induced subarctic phytoplankton bloom. Nature, 428(6982), 549-553. https://doi.org/10.1038/nature02437

28. Breidenich, C., Magraw, D., Rowley, A., Rubin, J. W., The, S., Journal, A., \& Apr, N. (1998). The Kyoto Protocol to the United Nations Framework Convention on Climate Change. The American Journal of International Law., 92(2), 315-331.

29. Breu, F., Guggenbichler, S., \& Wollmann, J. (2012). Manual for building tree volume and biomass allometric equations: from field measurement to prediction. Vasa. https://doi.org/10.1073/pnas.0703993104

30. Bronisz, K., Strub, M., Cieszewski, C., Bijak, S., Bronisz, A., Tomusiak, R., ... Zasada, M. (2016). Empirical equations for estimating aboveground biomass of betula pendula growing on former farmland in central Poland. Silva Fennica, 50(4), 1-17. https://doi.org/10.14214/sf.1559

31. Brown, S., \& Lugo, A. E. (1984). Biomass of tropical forests: a new estimate based on forest volumes. Science, 1290-3. https://doi.org/10.1126/science.223.4642.1290

32. Burnham, K. P., \& Anderson, D. R. (2002). Model Selection and Multimodel Inference: A practical Information-Theoretic-Approach. Model selection \& Multimodel inference. Springer, New York. https://doi.org/10.1016/j.ecolmodel.2003.11.004

33. Cabeza, L. F., Barreneche, C., Miró, L., Morera, J. M., Bartolí, E., \& Inés Fernández, A. (2013). Low carbon and low embodied energy materials in buildings: A review. Renewable and Sustainable Energy Reviews. https://doi.org/10.1016/j.rser.2013.03.017

34. Cairns, M. A., Brown, S., Helmer, E. H., Baumgardner, G. A., Cairns, M. A., Brown, S., ... Baumgardner, G. A. (1997). Root Biomass Allocation in the World 's Upland Forests. 
Oecologia, 111(1), 1-11. https://doi.org/10.1007/s004420050201

35. Chave, J. (2005). Measuring wood density for tropical forest trees. A field manual. Sixth Framework Programme (2002-2006). Toulouse, France.

36. Chave, J., Andalo, C., Brown, S., Cairns, M. A., Chambers, J. Q., Eamus, D., ... Yamakura, T. (2005). Tree allometry and improved estimation of carbon stocks and balance in tropical forests. Oecologia, 145(1), 87-99. https://doi.org/10.1007/s00442005-0100-x

37. Chave, J., Réjou-Méchain, M., Búrquez, A., Chidumayo, E., Colgan, M. S., Delitti, W. B. C., ... Vieilledent, G. (2014). Improved allometric models to estimate the aboveground biomass of tropical trees. Global Change Biology, 20(10), 3177-3190. https://doi.org/10.1111/gcb.12629

38. Chisholm, S. W. (2001). OCEANS: Dis-Crediting Ocean Fertilization. Science, 294(5541), 309-310. https://doi.org/10.1126/science.1065349

39. Chojnacky, D. C., Heath, L. S., \& Jenkins, J. C. (2014). Updated generalized biomass equations for North American tree species. Forestry, 87(1), 129-151. https://doi.org/10.1093/forestry/cpt053

40. Cienciala, E., Černý, M., Tatarinov, F., Apltauer, J., \& Exnerová, Z. (2006). Biomass functions applicable to Scots pine. Trees - Structure and Function, 20(4), 483-495. https://doi.org/10.1007/s00468-006-0064-4

41. Cifuentes-Jara, M., Henry, M., Réjou-Méchain, M., Wayson, C., Zapata-Cuartas, M., Piotto, D., ... Westfall, J. (2015). Guidelines for documenting and reporting tree allometric equations. Annals of Forest Science, 72(6), 763-768. https://doi.org/10.1007/s13595-014-0415-Z

42. Claesson, S., Sahlen, K., \& Lundmark, T. (2001). Functions for biomass estimation of young Pinus sylvestris, Picea abies and Betula spp. from stands in northern Sweden with high stand densities. Scandinavian Journal of Forest Research, 16(2), 138-146. https://doi.org/10.1080/028275801300088206

43. Clark, D., Brown, S., Kicklighter, D. W., Chambers, J. Q., Thomlinson, J. R., \& Ni, J. (2001). Measuring net primary production in forest concepts and field methods. Ecological Applications, 11(2), 356-370. https://doi.org/DOI: 10.2307/3060894

44. Clark, M. L., Roberts, D. A., Ewel, J. J., \& Clark, D. B. (2011). Estimation of tropical rain forest aboveground biomass with small-footprint lidar and hyperspectral sensors. Remote Sensing of Environment, 115(11), 2931-2942. https://doi.org/10.1016/j.rse.2010.08.029

45. Cleveland, W. S. (1979). Robust locally weighted regression and smoothing scatterplots. Journal of the American Statistical Association, 74(368), 829-836. https://doi.org/10.2307/2286407

46. Cretí, A., \& Joëts, M. (2017). Multiple bubbles in the European Union Emission Trading Scheme. Energy Policy, 107, 119-130. https://doi.org/10.1016/j.enpol.2017.04.018

47. Daugaviete, M. (2010). Biomasas uzkrāšanās baltalkšņa ( Alnus incana ( L .) Moench .) jaunaudzēs. MežzināTne, 21(54), 16-30.

48. Daugaviete, M., Gaitnieks, T., Kl̦aviņa, D., \& Teliševa, G. (2008). Oglekḷa akumulācija virszemes un sakņu biomasā bērza, baltalkšņa, priedes un egles jaunaudzēs lauksaimniecības zemēs. MežzināTne, 51(18), 35-52.

49. Di Cosmo, L., Gasparini, P., \& Tabacchi, G. (2016). A national-scale, stand-level model to predict total above-ground tree biomass from growing stock volume. Forest Ecology and Management, 361, 269-276. https://doi.org/10.1016/j.foreco.2015.11.008

50. Dibdiakova, J., \& Vadla, K. (2012). Basic density and moisture content of coniferous branches and wood in Northern Norway. In EPJ Web of Conferences (Vol. 33, p. 6). https://doi.org/10.1051/epjconf/20123302005

51. Dobson, M. C., Ulaby, F. T., LeToan, T., Beaudoin, A., Kasischke, E. S., \& Christensen, N. (1992). Dependence of radar backscatter on coniferous forest biomass. IEEE 
Transactions on Geoscience and Remote Sensing, 30(2), 412-415. https://doi.org/10.1109/36.134090

52. Dong, J., Kaufmann, R. K., Myneni, R. B., Tucker, C. J., Kauppi, P. E., Liski, J., ... Hughes, M. K. (2003). Remote sensing estimates of boreal and temperate forest woody biomass: Carbon pools, sources, and sinks. Remote Sensing of Environment, 84(3), 393410. https://doi.org/10.1016/S0034-4257(02)00130-X

53. Drēksa, A., Līpiņš, L., \& Sarmulis, Z. (2003). Priedes un egles stumbru mizas biezums. MežzināTne, 45, 131-137.

54. Ebuy, J., Lokombe, J. P., Ponette, Q., Sonwa, D., \& Picard, N. (2011). Allometric equation for predicting aboveground biomass of three tree species. Journal of Tropical Forest Science, 23(2), 125-132.

55. EEA. (2007). European Forest Types. Categories and types for sustainable forest management reporting and policy. EEA Technical report (Vol. 3). https://doi.org/10.3832/efor0425-003

56. Eggleston, H., Buendia, L., Miwa, K., Ngara, T., \& Tanabe, K. (2006). 2006 IPCC Guidelines for National Greenhouse Gas Inventories, Prepared by the National Greenhouse Gas Inventories Programme.Volume - IV Agriculture, Forestry and other and-use. IGES, Japan.

57. Elfving, B., Ulvcrona, K. A., \& Egnell, G. (2017). Biomass equations for lodgepole pine in northern Sweden. Canadian Journal of Forest Research, 47(1), 89-96. https://doi.org/10.1139/cjfr-2016-0131

58. Ene, L. T., Næsset, E., Gobakken, T., Gregoire, T. G., Ståhl, G., \& Nelson, R. (2012). Assessing the accuracy of regional LiDAR-based biomass estimation using a simulation approach. Remote Sensing of Environment, 123, 579-592. https://doi.org/10.1016/j.rse.2012.04.017

59. Erickson, J. R. (1972). The moisture content and specific gravity of the bark and wood of northern pulpwood species. USDA forest service research note NC-141.

60. European Commission. (2016). The European Union Emissions Trading System. https://doi.org/doi:10.2834/6083

61. EUROSTAT. (2017). Europe in figures - Eurostat yearbook 2017. Retrieved February 5, 2017, from http://ec.europa.eu/eurostat/statisticsexplained/index.php/Europe_in_figures_-_Eurostat_yearbook

62. Falkowski, P. (2000). The Global Carbon Cycle: A Test of Our Knowledge of Earth as a System. Science, 290(5490), 291-296. https://doi.org/10.1126/science.290.5490.291

63. Fan, Y., Jia, J. J., Wang, X., \& Xu, J. H. (2017). What policy adjustments in the EU ETS truly affected the carbon prices? Energy Policy, 103, 145-164. https://doi.org/10.1016/j.enpol.2017.01.008

64. FAO. (2011). State of Europe's forests 2011. Status \& Trends in Sustainable Forest Management in Europe. https://doi.org/10.1007/s13398-014-0173-7.2

65. FAO. (2014). Manual for visual assessment of forest crown condition. Retrieved from http://www.fao.org/3/a-i4214e.pdf

66. Federici, S., Vitullo, M., Tulipano, S., De Lauretis, R., \& Seufert, G. (2008). An approach to estimate carbon stocks change in forest carbon pools under the UNFCCC: the Italian case. IForest - Biogeosciences and Forestry, 1(2), 86-95. https://doi.org/10.3832/ifor0457-0010086

67. Feldpausch, T. R., Banin, L., Phillips, O. L., Baker, T. R., Lewis, S. L., Quesada, C. A., ... Lloyd, J. (2011). Height-diameter allometry of tropical forest trees. Biogeosciences, 8(5), 1081-1106. https://doi.org/10.5194/bg-8-1081-2011

68. Finér, L., Ohashi, M., Noguchi, K., \& Hirano, Y. (2011). Fine root production and turnover in forest ecosystems in relation to stand and environmental characteristics. Forest Ecology and Management, 262(11), 2008-2023. https://doi.org/10.1016/j.foreco.2011.08.042 
69. Forrester, D. I., Tachauer, I. H. H., Annighoefer, P., Barbeito, I., Pretzsch, H., RuizPeinado, R., ... Sileshi, G. W. (2017). Generalized biomass and leaf area allometric equations for European tree species incorporating stand structure, tree age and climate. Forest Ecology and Management, 396, 160-175. https://doi.org/10.1016/j.foreco.2017.04.011

70. Freund, P., \& Ormerod, W. G. (1997). Progress toward storage of carbon dioxide. Energy Conversion and Management, 38, 199-204. https://doi.org/10.1016/S01968904(96)00269-5

71. Gardiner, B., Leban, J. M., Auty, D., \& Simpson, H. (2011). Models for predicting wood density of British-grown Sitka spruce. Forestry, 84(2), 119-132. https://doi.org/10.1093/forestry/cpq050

72. Garnett, M. H., Ineson, P., Stevenson, A. C., \& Howard, D. C. (2001). Terrestrial organic carbon storage in a British moorland. Global Change Biology, 7(4), 375-388. https://doi.org/10.1046/j.1365-2486.2001.00382.x

73. Gasparini, P., \& Cosmo, L. Di. (2015). Forest carbon in Italian forests : Stocks , inherent variability and predictability using NFI data. Forest Ecology and Management, 337, 186195. https://doi.org/10.1016/j.foreco.2014.11.012

74. Gibbs, H. K., Brown, S., Niles, J. O., \& Foley, J. A. (2007). Monitoring and estimating tropical forest carbon stocks: making REDD a reality. Environmental Research Letters, 2(4), 045023. https://doi.org/10.1088/1748-9326/2/4/045023

75. Gorte, R. W. (2009). Carbon Sequestration in Forests. Congressional Research Service, 4, 2-37. https://doi.org/10.1079/PAVSNNR20094041

76. Goulden, M. L., Munger, J. W., Fan, S. M., Daube, B. C., \& Wofsy, S. C. (1996). Measurements of carbon sequestration by long-term eddy covariance: Methods and a critical evaluation of accuracy. Global Change Biology. https://doi.org/10.1111/j.13652486.1996.tb00070.x

77. Grassi, G., House, J., Dentener, F., Federici, S., den Elzen, M., \& Penman, J. (2017). The key role of forests in meeting climate targets requires science for credible mitigation. Nature Climate Change, 7(3), 220-226. https://doi.org/10.1038/nclimate3227

78. Greene, C. H., \& Pershing, A. J. (2007). OCEANS: Climate Drives Sea Change. Science, 315(5815), 1084-1085. https://doi.org/10.1126/science.1136495

79. Gren, I.-M., \& Zeleke, A. A. (2016). Policy design for forest carbon sequestration: A review of the literature. Forest Policy and Economics, 70, 128-136. https://doi.org/10.1016/j.forpol.2016.06.008

80. Gustavsson, L., Pingoud, K., \& Sathre, R. (2006). Carbon dioxide balance of wood substitution: Comparing concrete- and wood-framed buildings. Mitigation and Adaptation Strategies for Global Change, 11(3), 667-691. https://doi.org/10.1007/s11027-006-7207-1

81. Hakkila, P. (1972). Mechanized Harvesting of Stumps and Roots: A Sub-project of the Joint Nordic Research Programme for the Utilization of Logging Residues. Communicationes Instituti Forestalis Fenniae, (77), 71.

82. Hakkila, P. (1979). Wood density surveys and dry weight tables for pine, spruce andbirch stems in Finland. Communicationes Instituti Forestalis Fenniae, 96(3), 59.

83. Hakkila, P. (1989). Utilization of Residual Forest Biomass. Springer-Verlag Berlin Heidelberg. https://doi.org/10.1017/CBO9781107415324.004

84. Hakkila, P., \& Uusvaara, O. (1968). On the basic density of plantation-grown Norway spruces. Communicationes Instituti Forestalis Fenniae, 66(6), 1-23.

85. Hawkins, E., Ortega, P., Suckling, E., Schurer, A., Hegerl, G., Jones, P., ... van Oldenborgh, G. J. (2017). Estimating changes in global temperature since the preindustrial period. Bulletin of the American Meteorological Society, 98 (9), 1841-1856. https://doi.org/10.1175/BAMS-D-16-0007.1

86. Henry, M., Besnard, A., Asante, W. A., Eshun, J., Adu-Bredu, S., Valentini, R., ... Saint- 
André, L. (2010). Wood density, phytomass variations within and among trees, and allometric equations in a tropical rainforest of Africa. Forest Ecology and Management, 260(8), 1375-1388. https://doi.org/10.1016/j.foreco.2010.07.040

87. Henry, M., Bombelli, A., Trotta, C., Alessandrini, A., Birigazzi, L., Sola, G., ... SaintAndré, L. (2013). GlobAllomeTree: International platform for tree allometric equations to support volume, biomass and carbon assessment. IForest, 6(6). https://doi.org/10.3832/ifor0901-006

88. Herajarvi, H. (2004). Variation of basic density and brinell hardness within mature finnish betula pendula and b. pubescens stems. Wood and Fiber Science, 36(2), 216-227.

89. Heräjärvi, H. (2009). Wood product manufacture potential of European and hybrid aspen in Finland. In In: Proceedings of the 5th meeting of the Nordic-Baltic Network in Wood Material Science and Engineering (WSE) October 1-2, 2009 Copenhagen, Denmark. (Vol. 49, pp. 121-126).

90. Heräjärvi, H., \& Junkkonen, R. (2006). Wood density and growth rate of European and hybrid aspen in southern Finland. Baltic Forestry, 12(1), 2-8.

91. Houghton, R. A., Hall, F., \& Goetz, S. J. (2009). Importance of biomass in the global carbon cycle. Journal of Geophysical Research: Biogeosciences, 114(3), 1-13. https://doi.org/10.1029/2009JG000935

92. Huijgen, W. J. J., \& Comans, R. N. J. (2003). Carbon dioxide sequestration by mineral carbonation. Environmental science \& technology (Vol. 43). https://doi.org/ECN-C-03016

93. Hulme, M. (2016). $1.5{ }^{\circ} \mathrm{C}$ and climate research after the Paris Agreement. Nature Climate Change, 6(3), 222-224. https://doi.org/10.1038/nclimate2939

94. Hunter, M. O., Keller, M., Victoria, D., \& Morton, D. C. (2013). Tree height and tropical forest biomass estimation. Biogeosciences, 10(12), 8385-8399. https://doi.org/10.5194/bg-10-8385-2013

95. Hunziker, M., Sigurdsson, B. D., Halldorsson, G., Schwanghart, W., \& Kuhn, N. (2014). Biomass allometries and coarse root biomass distribution of mountain birch in southern Iceland. ICEL. AGRIC. SCI., 27, 111-125.

96. Hyde, P., Dubayah, R., Walker, W., Blair, J. B., Hofton, M., \& Hunsaker, C. (2006). Mapping forest structure for wildlife habitat analysis using multi-sensor (LiDAR, SAR/InSAR, ETM+, Quickbird) synergy. Remote Sensing of Environment, 102(1-2), 6373. https://doi.org/10.1016/j.rse.2006.01.021

97. Ilic, J., Boland, D., McDonald, M., Downes, G., \& Blakemore, P. (2000). Woody density: Phase 1 - State of knowledge. NCAS technical report no.18.

98. IPCC. (2003). Good Practice Guidance for Land Use, Land-Use Change and Forestry. IGES, Japan.

99. IPCC. (2005). IPCC special report on carbon dioxide capture and storage. IPCC Special Report on Carbon Dioxide Capture and Storage (Vol. 2).

100. Jackson, R. B. (2005). Trading Water for Carbon with Biological Carbon Sequestration. Science, 310(5756), 1944-1947. https://doi.org/10.1126/science.1119282

101. Jackson, R. B., Canadell, J., Ehleringer, J. R., Mooney, H. A., Sala, O. E., \& Schulze, E. D. (1996). A global analysis of root distributions for terrestrial biomes. Oecologia, 108(3), 389-411. https://doi.org/10.1007/BF00333714

102. Jalkanen, A., Makipaa, R., Stahl, G., Lehtonen, A., \& Petersson, H. (2005). Estimation of the biomass stock of trees in Sweden: comparison of biomass equations and agedependent biomass expansion factors. Annals of Forest Science, 62(8), 845-851. https://doi.org/10.1051/forest:2005075

103. Jansons, Ā. (2017). Siltumnīcefekta gāzu emisiju un CO2 piesaistes novērtējums vecās mežaudzēs. Pārskats par pētījuma 2017. gada rezultātiem.

104. Jenkins, J. C., Chojnacky, D. C., Heath, L. S., \& Birdsey, R. a. (2003). National-scale biomass estimators for United States tree species. Forest Science, 49(1), 12-35. 
105. Jenkins, J. C., Chojnacky, D. C., Heath, L. S., \& Birdsey, R. A. (2004). Comprehensive Database of Diameter-based Biomass Regressions for North American Tree Species. General Technical Report NE-319. Newtown Square, PA: Forest Service, Northeastern Research Station. America.

106. Johansson, K. (1993). Influence of initial spacing and tree class on the basic density of picea abies. Scandinavian Journal of Forest Research, 8(1-4), 18-27. https://doi.org/10.1080/02827589309382752

107. Johansson, T. (2000). Biomass equations for determining fractions of European aspen growing on abandoned farmland and some practical implications. Biomass and Bioenergy, 18(2), 147-159. https://doi.org/10.1016/S0961-9534(99)00078-1

108. Johansson, T. (2002). Increment and biomass in 26- to 91-year-old European aspen and some practical implications. Biomass and Bioenergy, 23(4), 245-255. https://doi.org/10.1016/S0961-9534(02)00056-9

109. Johansson, T. (2005). Stem volume equations and basic density for grey alder and common alder in Sweden. Forestry. https://doi.org/10.1093/forestry/cpi023

110. Johansson, T. (2007). Biomass production and allometric above- and below-ground relations for young birch stands planted at four spacings on abandoned farmland. Forestry, 80(1), 41-52. https://doi.org/10.1093/forestry/cpl049

111. Jones, D. A., \& O’Hara, K. L. (2012). Carbon density in managed coast redwood stands: Implications for forest carbon estimation. Forestry, 85(1), 99-110. https://doi.org/10.1093/forestry/cpr063

112. Jyske, T., Mäkinen, H., \& Saranpää, P. (2008). Wood density within Norway spruce stems. Silva Fennica, 42(January 2007), 439-455.

113. Karki, T. (2001). Variation of wood density and shrinkage in European aspen (Populus tremula). Holz Als Roh-Und Werkstoff, 59(1-2), 79-84.

114. Kellndorfer, J. M., Walker, W. S., LaPoint, E., Kirsch, K., Bishop, J., \& Fiske, G. (2010). Statistical fusion of lidar, InSAR, and optical remote sensing data for forest stand height characterization: A regional-scale method based on LVIS, SRTM, Landsat ETM+, and ancillary data sets. Journal of Geophysical Research: Biogeosciences, 115, 1-10. https://doi.org/10.1029/2009JG000997

115. Klara, S. M., Srivastava, R. D., \& McIlvried, H. G. (2003). Integrated collaborative technology development program for $\mathrm{CO} 2$ sequestration in geologic formations - United States Department of Energy R\&D. Energy Conversion and Management. https://doi.org/10.1016/S0196-8904(03)00042-6

116. Köhl, M., \& Frühwald, A. (2009). Permanent wood sequestration: No solution to the global carbon dioxide problem. ChemSusChem. https://doi.org/10.1002/cssc.200800240

117. Kolari, P., Pumpanen, J., Rannik, Ü., Ilvesniemi, H., Hari, P., \& Berninger, F. (2004). Carbon balance of different aged Scots pine forests in Southern Finland. Global Change Biology. https://doi.org/10.1111/j.1529-8817.2003.00797.x

118. Kops, L. (1997). Būvkoks. Rīga: Mācību apgāds.

119. Korsmo, H. (1995). Weight equations for determining biomass fractions of young hardwoods from natural regenerated stands. Scandinavian Journal of Forest Research, 10(1), 333-346. https://doi.org/10.1080/02827589509382900

120. Köster, K., Metslaid, M., Engelhart, J., \& Köster, E. (2015). Dead wood basic density, and the concentration of carbon and nitrogen for main tree species in managed hemiboreal forests. Forest Ecology and Management. https://doi.org/10.1016/j.foreco.2015.06.039

121. Kozak, A. (1970). Methods for ensuring additivity of biomass components by regression analysis. The Forestry Chronicle. https://doi.org/10.5558/tfc46402-5

122. Kumar, R., Pandey, S., \& Pandey, a. (2006). Plant roots and carbon sequestration. Current Science, 91(7), 885-890.

123. Kumar, R., Rawat, K. S., Singh, J., Singh, A., \& Rai, A. (2013). Soil aggregation 
dynamics and carbon sequestration. Journal of Applied and Natural Sciences, 250-267.

124. Laasasenaho, J., Melkas, T., \& Aldén, S. (2005). Modelling bark thickness of Picea abies with taper curves. Forest Ecology and Management, 206, 35-47. https://doi.org/10.1016/j.foreco.2004.10.058

125. Lackner, K. S. (2003). A Guide to CO2 Sequestration. Science, 300(5626), 1677-1678. https://doi.org/10.1126/science.1079033

126. Lal, R. (2001). World cropland soils as a source or sink for atmospheric carbon. Advances in Agronomy, 71, 145-191.

127. Lal, R. (2004). Soil Carbon Sequestration Impacts on Global Climate Change and Food Security. Science, 304(5677), 1623-1627. https://doi.org/10.1126/science.1097396

128. Lal, R. (2005). Forest soils and carbon sequestration. Forest Ecology and Management, 220(1-3), 242-258. https://doi.org/10.1016/j.foreco.2005.08.015

129. Lal, R. (2008). Carbon sequestration. Philosophical Transactions of the Royal Society B, 363(1492), 815-30. https://doi.org/10.1098/rstb.2007.2185

130. Latifi, H., Fassnacht, F., \& Koch, B. (2012). Forest structure modeling with combined airborne hyperspectral and LiDAR data. Remote Sensing of Environment, 121, 10-25. https://doi.org/10.1016/j.rse.2012.01.015

131. Law, B. E., Sun, O. J., Campbell, J., Van Tuyl, S., \& Thornton, P. E. (2003). Changes in carbon storage and fluxes in a chronosequence of ponderosa pine. Global Change Biology. https://doi.org/10.1046/j.1365-2486.2003.00624.x

132. Le Toan, T., Beaudoin, A., Riom, J., \& Guyon, D. (1992). Relating Forest Biomass to SAR Data. IEEE Transactions on Geoscience and Remote Sensing, 30(2), 403-411. https://doi.org/10.1109/36.134089

133. Le Toan, T., Quegan, S., Davidson, M. W. J., Balzter, H., Paillou, P., Papathanassiou, K., ... Ulander, L. (2011). The BIOMASS mission: Mapping global forest biomass to better understand the terrestrial carbon cycle. Remote Sensing of Environment, 115(11), 28502860. https://doi.org/10.1016/j.rse.2011.03.020

134. Ledermann, T., \& Neumann, M. (2006). Biomass equations from data of old long-term experimental plots. Austrian Journal of Forest Science, 123(1-2), 47-64.

135. Lehtonen, A., Cienciala, E., Tatarinov, F., \& Makipaa, R. (2007). Uncertainty estimation of biomass expansion factors for Norway spruce in the Czech Republic. Annals of Forest Science, 64(2), 133-140. https://doi.org/10.1051/forest:2006097

136. Lehtonen, A., Mäkipää, R., Heikkinen, J., Sievänen, R., \& Liski, J. (2004). Biomass expansion factors (BEFs) for Scots pine, Norway spruce and birch according to stand age for boreal forests. Forest Ecology and Management, 188(1-3), 211-224. https://doi.org/10.1016/j.foreco.2003.07.008

137. Lei, S., \& Shirong, L. (2017). Methods of Estimating Forest Biomass: A Review. In S. T. Jaya (Ed.), Biomass Volume Estimation and Valorization for Energy (pp. 23-46). InTech. https://doi.org/10.5772/711

138. Leifeld, J., Müller, M., \& Fuhrer, J. (2011). Peatland subsidence and carbon loss from drained temperate fens. Soil Use and Management, 27(2), 170-176. https://doi.org/10.1111/j.1475-2743.2011.00327.x

139. Levillain, J., Thongo M'Bou, A., Deleporte, P., Saint-Andr??, L., \& Jourdan, C. (2011). Is the simple auger coring method reliable for below-ground standing biomass estimation in Eucalyptus forest plantations? Annals of Botany, 108(1), 221-230. https://doi.org/10.1093/aob/mcr102

140. Levy, P. E., Hale, S. E., \& Nicoll, B. C. (2004). Biomass expansion factors and root:shoot ratios for coniferous tree species in Great Britain. Forestry, 77(5), 421-430. https://doi.org/10.1093/forestry/77.5.421

141. Lībiete, Z., Matisons, R., Rieksts-riekstiņš, J., Priedîtis, A., \& Jansons, J. (2017). Aboveground Biomass Models of 40-year-old Norway Spruce in Latvia. Baltic Forestry, 23(2), $515-521$. 
142. Liepa, I. (2011). Mizas nozīme krājas tekošā pieauguma noteikšanā. MežzināTne, 24(57), $58-64$.

143. Liepa, I., \& Blija, T. (2008). Latvijas egḷu mežu koku biomasas struktūra. LLU Raksti, 20(315), 32-37.

144. Liepiņš, J., Lazdiņš, A., \& Liepiņš, K. (2017). Equations for estimating above- and belowground biomass of Norway spruce, Scots pine, birch spp. and European aspen in Latvia. Scandinavian Journal of Forest Research, 7581(June), 1-13. https://doi.org/10.1080/02827581.2017.1337923

145. Liepiņš, J., \& Liepinsš, K. (2015). Evaluation of bark volume of four tree species in Latvia. In Research for Rural Development. (Vol. 2, pp. 22-28).

146. Liepiņš, J., \& Liepiņš, K. (2017). Mean basic density and its axial variation in scots pine, Norway spruce and birch stems. Research for Rural Development, 1, 21-27. https://doi.org/10.22616/rrd.23.2017.003

147. Liepins, K., \& Rieksts-Riekstins, J. (2013). Stemwood Density of Juvenile Silver Birch Trees (Betula pendula Roth) from Plantations on Former Farmlands. Baltic Forestry, 19, 179-186.

148. Lima, A. J. N., Suwa, R., De Mello Ribeiro, G. H. P., Kajimoto, T., Dos Santos, J., Da Silva, R. P., ... Higuchi, N. (2012). Allometric models for estimating above- and belowground biomass in Amazonian forests at São Gabriel da Cachoeira in the upper Rio Negro, Brazil. Forest Ecology and Management, 277, 163-172. https://doi.org/10.1016/j.foreco.2012.04.028

149. Lindroth, A., Grelle, A., \& Moren, A.-S. (1998). Long-term measurements of boreal forest carbon balance reveal large temperature sensitivity. Global Change Biology. https://doi.org/10.1046/j.1365-2486.1998.00165.x

150. Līpiņš, L., \& Liepa, I. (2007). Apaļo kokmateriālu uzmērī̌sana. Jelgava, LLU: Latgales druka.

151. Litton, C. M., Raich, J. W., \& Ryan, M. G. (2007). Carbon allocation in forest ecosystems. Global Change Biology, 13(10), 2089-2109. https://doi.org/10.1111/j.13652486.2007.01420.x

152. Lohila, A., Minkkinen, K., Aurela, M., Tuovinen, J.-P., Penttil, T., Ojanen, P., \& Laurila, T. (2011). Greenhouse gas flux measurements in a forestry-drained peatland indicate a large carbon sink. Biogeosciences, 8(11), 3203-3218.

153. Lu, D. (2006). The potential and challenge of remote sensing-based biomass estimation. International Journal of Remote Sensing. https://doi.org/10.1080/01431160500486732

154. Lu, D., Chen, Q., Wang, G., Liu, L., Li, G., \& Moran, E. (2016). A survey of remote sensing-based aboveground biomass estimation methods in forest ecosystems. International Journal of Digital Earth. https://doi.org/10.1080/17538947.2014.990526

155. Luoma, V., Saarinen, N., Wulder, M. A., White, J. C., Vastaranta, M., Holopainen, M., \& Hyyppä, J. (2017). Assessing precision in conventional field measurements of individual tree attributes. Forests, 8(2). https://doi.org/10.3390/f8020038

156. Lupikis, A., Bardule, A., Lazdins, A., Stola, J., \& Butlers, A. (2017). Carbon stock changes in drained arable organic soils in Latvia: Results of a pilot study. Agronomy Research, 15(3), 788-798.

157. Magalhães, T. M., \& Seifert, T. (2015). Tree component biomass expansion factors and root-to-shoot ratio of Lebombo ironwood: Measurement uncertainty. Carbon Balance and Management, 10(1). https://doi.org/10.1186/s13021-015-0019-4

158. Mäkinen, H., Saranpää, P., \& Linder, S. (2002). Wood-density variation of Norway spruce in relation to nutrient optimization and fibre dimensions. Canadian Journal of Forest Research, 32(2), 185-194. https://doi.org/10.1139/x01-186

159. Malhi, Y., Aragão, L. E. O. C., Metcalfe, D. B., Paiva, R., Quesada, C. A., Almeida, S., ... Teixeira, L. M. (2009). Comprehensive assessment of carbon productivity, allocation and storage in three Amazonian forests. Global Change Biology, 15(5), 1255-1274. 
https://doi.org/10.1111/j.1365-2486.2008.01780.x

160. Marklund, L. G. (1987). Biomass equations for spruce in Sweden. Swedish University of Agricultural Sciences, Department of Forest Survey. Report 43.

161. Marklund, L. G. (1988). Biomass functions for pine spruce and birch in Sweden. Swedish University of Agricultural Sciences, Department of Forest Survey. Report 45.

162. Martin, A. R., \& Thomas, S. C. (2011). A reassessment of carbon content in tropical trees. PLoS ONE, 6(8). https://doi.org/10.1371/journal.pone.0023533

163. Martin, J. H., Coale, K. H., Johnson, K. S., Fitzwater, S. E., Gordon, R. M., Tanner, S. J., ... Tindale, N. W. (1994). Testing the iron hypothesis in ecosystems of the equatorial Pacific Ocean. Nature, 371(6493), 123-129. https://doi.org/10.1038/371123a0

164. Matthews, H. D. (2007). Implications of CO2 fertilization for future climate change in a coupled climate-carbon model. Global Change Biology, 13(5), 1068-1078. https://doi.org/10.1111/j.1365-2486.2007.01343.x

165. McRoberts, R. E., Liknes, G. C., \& Domke, G. M. (2014). Using a remote sensing-based, percent tree cover map to enhance forest inventory estimation. Forest Ecology and Management, 331, 12-18. https://doi.org/10.1016/j.foreco.2014.07.025

166. Meyer, T. J. (1989). Chemical Approaches To Artificial Photosynthesis. Accounts of Chemical Research, 22(5), 163-170. https://doi.org/10.1021/ar00161a001

167. Miezīte, O., Liepa, I., \& Lazdinšs, A. (2011). Carbon accumulation in overground and root biomass of grey alder (Alnus Incana (L.) Moench) aegopodiosa. In Research for Rural Development. Annual 17th International Scientific Conference Proceedings (Vol. 2, pp. 46-51).

168. Milchunas, D. G. (2012). Biases and errors associated with different root production methods and their effects on field estimates of belowground net primary production. In Measuring Roots: An Updated Approach (pp. 303-339). https://doi.org/10.1007/978-3642-22067-8_16

169. Millers, M., \& Magaznieks, J. (2012). Scots Pine ( Pinus sylvestris L .) Stem Wood and Bark Moisture and Density Influencing Factors. In Research for Rural Development. Annual 18th International Scientific Conference Proceedings (Vol. 2, pp. 91-98).

170. Mokany, K., Raison, R. J., \& Prokushkin, A. S. (2006). Critical analysis of root: Shoot ratios in terrestrial biomes. Global Change Biology, 12(1), 84-96. https://doi.org/10.1111/j.1365-2486.2005.001043.x

171. Montès, N., Gauquelin, T., Badri, W., Bertaudière, V., \& Zaoui, E. H. (2000). A nondestructive method for estimating above-ground forest biomass in threatened woodlands. Forest Ecology and Management, 130(1-3), 37-46. https://doi.org/10.1016/S03781127(99)00188-7

172. Mosera, G., Christoph, L., Marina, R., Sophie, G., Nathalie, S., \& Dietrich, H. (2010). Biomass and productivity of fine and coarse roots in five tropical mountain forests stands along an altitudinal transect in southern Ecuador. Plant Ecology and Diversity, 3(2), 151164. https://doi.org/10.1016/j.celrep.2011.1011.1001.7.

173. Motulsky, H., \& Arthur, C. (2003). Fitting Models to Biological Data using Linear and Nonlinear Regression. A practical guide to curve fitting. Oxford University Press. San Diego CA: GraphPad Software. https://doi.org/10.1002/pst.167

174. Mugasha, W. A., Eid, T., Bollandsås, O. M., Malimbwi, R. E., Chamshama, S. A. O., Zahabu, E., \& Katani, J. Z. (2013). Allometric models for prediction of above- and belowground biomass of trees in the miombo woodlands of Tanzania. Forest Ecology and Management, 310, 87-101. https://doi.org/10.1016/j.foreco.2013.08.003

175. Muukkonen, P. (2007). Generalized allometric volume and biomass equations for some tree species in Europe. European Journal of Forest Research, 126(2), 157-166. https://doi.org/10.1007/s10342-007-0168-4

176. Nabuurs, G., Wyngaert, I., Daamen, W., Helmink, A., Groot, W., Knol, W., ... Kuikman, P. (2005). National System of Greenhouse Gas Reporting for Forest and Nature Areas 
under UNFCCC in The Netherlands. Alterra-report 1035.1.

177. Narbel, P. A., Hansen, J. P., \& Lien, J. R. (2014). Energy technologies and economics. Energy Technologies and Economics. https://doi.org/10.1007/978-3-319-08225-7

178. Neumann, M., Moreno, A., Mues, V., Härkönen, S., Mura, M., Bouriaud, O., ... Hasenauer, H. (2016). Comparison of carbon estimation methods for European forests. Forest Ecology and Management, 361, 397-420. https://doi.org/10.1016/j.foreco.2015.11.016

179. Ngomanda, A., Engone Obiang, N. L., Lebamba, J., Moundounga Mavouroulou, Q., Gomat, H., Mankou, G. S., ... Picard, N. (2014). Site-specific versus pantropical allometric equations: Which option to estimate the biomass of a moist central African forest? Forest Ecology and Management, 312, 1-9. https://doi.org/10.1016/j.foreco.2013.10.029

180. Ni, Y., Eskeland, G. S., Giske, J., \& Hansen, J. P. (2016). The global potential for carbon capture and storage from forestry. Carbon Balance and Management, 11(1), 8. https://doi.org/10.1186/s13021-016-0044-y

181. Offenthaler, I., \& Hochbichler, E. (2006). Estimation of root biomass of Austrian forest tree species. Austrian Journal of Forest Science, 123(1-2), 65-86.

182. Ojanen, P., Minkkinen, K., Alm, J., \& Penttilä, T. (2010). Soil-atmosphere CO2, CH4 and $\mathrm{N} 2 \mathrm{O}$ fluxes in boreal forestry-drained peatlands. Forest Ecology and Management, 260(3), 411-421. https://doi.org/10.1016/J.FORECO.2010.04.036

183. Pan, Y., Birdsey, R. a, Fang, J., Houghton, R., Kauppi, P. E., Kurz, W. a, ... Hayes, D. (2011). A large and persistent carbon sink in the world's forests. Science, 333, 988-993. https://doi.org/10.1126/science.1201609

184. Pan, Y., Luo, T., Birdsey, R., Hom, J., \& Melillo, J. (2004). New estimates of carbon storage and sequestration in China'S forests: Effects of age-class and method on inventory-based carbon estimation. Climatic Change, 67(2-3), 211-236. https://doi.org/10.1007/s10584-004-2799-5

185. Patenaude, G., Hill, R. A., Milne, R., Gaveau, D. L. A., Briggs, B. B. J., \& Dawson, T. P. (2004). Quantifying forest above ground carbon content using LiDAR remote sensing. Remote Sensing of Environment, 93(3), 368-380. https://doi.org/10.1016/j.rse.2004.07.016

186. Peng, C., Zhang, L., \& Liu, J. (2001). Developing and validating nonlinear heightdiameter models for major tree species of Ontarios Boreal Forests. Northern Journal of Applied Forestry, 18(3), 87-94.

187. Petersson, H., Holm, S., Ståhl, G., Alger, D., Fridman, J., Lehtonen, A., ... Mäkipää, R. (2012). Individual tree biomass equations or biomass expansion factors for assessment of carbon stock changes in living biomass - A comparative study. Forest Ecology and Management, 270, 78-84. https://doi.org/10.1016/j.foreco.2012.01.004

188. Petersson, H., \& Stahl, G. (2006). Functions for below-ground biomass of Pinus sylvestris, Picea abies, Betula pendula and Betula publescens in Sweden. Scandinavian Journal of Forest Research, 21(7), 84-93. https://doi.org/10.1080/14004080500486864

189. Petrokofsky, G., Kanamaru, H., Achard, F., Goetz, S. J., Joosten, H., Holmgren, P., ... Wattenbach, M. (2012). Comparison of methods for measuring and assessing carbon stocks and carbon stock changes in terrestrial carbon pools. How do the accuracy and precision of current methods compare? A systematic review protocol. Environmental Evidence, 1(1), 6. https://doi.org/10.1186/2047-2382-1-6

190. Phalla, T., Ota, T., Mizoue, N., Kajisa, T., Yoshida, S., Vuthy, M., \& Heng, S. (2017). The Importance of Tree Height in Estimating Individual Tree Biomass while Considering Errors in Measurements and Allometric Models. Journal of Agricultural Science, 40(1), 131-140. https://doi.org/10.17503/agrivita.v40i1.1730

191. Picard, N., Rutishauser, E., Ploton, P., Ngomanda, A., \& Henry, M. (2015). Should tree biomass allometry be restricted to power models? Forest Ecology and Management, 353, 
156-163. https://doi.org/10.1016/j.foreco.2015.05.035

192. Picard, N., Saint André, L., \& Henry, M. (2012). Manual for building tree volume and biomass allometric equations: from field measurement to prediction. Rome: Food and Agriculture Organization of the United Nation. https://doi.org/10.1073/pnas.0703993104

193. Piñeiro, G., Perelman, S., Guerschman, J. P., \& Paruelo, J. M. (2008). How to evaluate models: Observed vs. predicted or predicted vs. observed? Ecological Modelling, 216(34), 316-322. https://doi.org/10.1016/j.ecolmodel.2008.05.006

194. Pires, J. C. M., Martins, F. G., Alvim-Ferraz, M. C. M., \& Simoes, M. (2011). Recent developments on carbon capture and storage: An overview. Chemical Engineering Research and Design, 89(9), 1446-1460. https://doi.org/10.1016/j.cherd.2011.01.028

195. Pretzsch, H., Biber, P., Durský, J., Von Gadow, K., Hasenauer, H., Kändler, G., ... Sterba, H. (2002). Recommendations for Standardized Documentation and Further Development of Forest Growth Simulators. Forstwissenschaftliches Centralblatt, 121(3), 138-151. https://doi.org/10.1046/j.1439-0337.2002.00138.x

196. Ravindranath, N., \& Ostwald, M. (2008a). Methods for Below-Ground Biomass. In N. Ravindranath \& M. Ostwald (Eds.), Carbon Inventory Methods Handbook for Greenhouse Gas Inventory, Carbon Mitigation and Roundwood Production Projects (pp. 149-156). Springer Science + Business Media B.V.

197. Ravindranath, N., \& Ostwald, M. (2008b). Methods for Estimating Above-Ground Biomass. In N. Ravindranath \& M. Ostwald (Eds.), Carbon Inventory Methods Handbook for Greenhouse Gas Inventory, Carbon Mitigation and Roundwood Production Projects (pp. 113-147). Springer Science + Business Media B.V.

198. Repola, J. (2006). Models for vertical wood density of Scots pine, Norway spruce and birch stems, and their application to determine average wood density. Silva Fennica, 40(July), 673-685.

199. Repola, J. (2008). Biomass equations for birch in Finland. Silva Fennica, 42(4), 605-624.

200. Repola, J. (2009). Biomass equations for Scots pine and Norway spruce in Finland. Silva Fennica, 43(May), 625-647.

201. Repola, J. (2013). Modelling tree biomasses in Finland. Dissertationes Forestales (Vol. 158).

202. Repola, J., \& Ulvcrona, K. A. (2014). Modelling biomass of young and dense Scots pine (Pinus sylvestris L.) dominated mixed forests in northern Sweden. Silva Fennica, 48(5), 21 p. https://doi.org/10.14214/sf.1190

203. Ritson, P., \& Sochacki, S. (2003). Measurement and prediction of biomass and carbon content of Pinus pinaster trees in farm forestry plantations, south-western Australia. Forest Ecology and Management. https://doi.org/10.1016/S0378-1127(02)00121-4

204. Rogelj, J., den Elzen, M., Höhne, N., Fransen, T., Fekete, H., Winkler, H., ... Meinshausen, M. (2016). Paris Agreement climate proposals need a boost to keep warming well below $2{ }^{\circ} \mathrm{C}$. Nature, 534(7609), 631-639. https://doi.org/10.1038/nature18307

205. Roxburgh, S. H., Paul, K. I., Clifford, D., England, J. R., \& Raison, R. J. (2015). Guidelines for constructing allometric models for the prediction of woody biomass: How many individuals to harvest? Ecosphere, 6(3), 38. https://doi.org/10.1890/ES14-00251.1

206. Royal Society. (2009). Geoengineering the climate: science, governance and uncertainty. Clean Technologies and Environmental Policy. https://doi.org/10.1007/s10098-0100287-3

207. Rubin, E. S. (2012). Understanding the pitfalls of CCS cost estimates. International Journal of Greenhouse Gas Control, 10, 181-190. https://doi.org/10.1016/j.ijggc.2012.06.004

208. Rytter, L., Ingerslev, M., Kilpeläinen, A., Torssonen, P., Lazdina, D., Löf, M., ... Stener, L.-G. (2016). Increased forest biomass production in the Nordic and Baltic countries - A review on current and future opportunities. Silva Fennica, 50(5), 1-33. 
https://doi.org/10.14214/sf.1660

209. Rytter, L., Johansson, K., Karlsson, B., \& Stener, L. G. (2013). Tree species, genetics and regeneration for bioenergy feedstock in northern Europe. In Forest BioEnergy Production: Management, Carbon Sequestration and Adaptation (pp. 7-37). https://doi.org/10.1007/978-1-4614-8391-5_2

210. Saranpää, P. (1994). Basic density, longitudinal shrinkage and tracheid length of juvenile wood of picea abies (L.) karst. Scandinavian Journal of Forest Research, 9(1-4), 68-74. https://doi.org/10.1080/02827589409382814

211. Saranpää, P. (2003). Wood density and growth. In John R. Barnett \& G. Jeronimidis (Eds.), Wood quality and its biological basis (p. 240). USA: Blackwell Publishing.

212. Sarker, L. R. (2010). Estimation of forest biomass using remote sensing. PhD Thesis, Hong Kong Polytechnic University.

213. Sarmulis, Z., Drēksa, A., Līpiņš, L., \& Leontjevs, D. (2005). Egles stumbra dimensionāls vērtējums. LLU Raksti, 14(309), 1-8.

214. Sasaki, N., Chheng, K., Mizoue, N., Abe, I., \& Lowe, A. J. (2016). Forest reference emission level and carbon sequestration in Cambodia. Global Ecology and Conservation. https://doi.org/10.1016/j.gecco.2016.05.004

215. Savaresi, A. (2016). The Paris Agreement: a new beginning? Journal of Energy \& Natural Resources Law, 34(1), 16-26. https://doi.org/10.1080/02646811.2016.1133983

216. Schepaschenko, D., Moltchanova, E., Shvidenko, A., Blyshchyk, V., Dmitriev, E., Martynenko, O., ... Kraxner, F. (2018). Improved estimates of biomass expansion factors for Russian forests. Forests, 9(6), 1-23. https://doi.org/10.3390/f9060312

217. Scholes, R. J., \& Noble, I. R. (2001). Storing carbon on land. Science, 294(5544), 10121013. https://doi.org/10.1126/science. 1065307

218. Schrag, D. P. (2007). Preparing to Capture Carbon. Science, 315(5813), 812-813. https://doi.org/10.1126/science.1137632

219. Sharma, V., \& Chaudhry, S. (2015). An evaluation of existing methods for assessment of above-ground biomass in forests. International Journal of Engineering Research and Science \& Technology, 4(2), 1-20.

220. Sileshi, G. W. (2014). A critical review of forest biomass estimation models, common mistakes and corrective measures. Forest Ecology and Management, 329, 237-254. https://doi.org/10.1016/j.foreco.2014.06.026

221. Simola, P. (1977). The biomass of small-sized hardwood trees. Folia Forestalia, 302, 16.

222. Singh, T. (1984). Variation in the Ovendry Wood Density of Ten Prairie Tree Species. The Forestry Chronicle, 60, 217-221.

223. Skovsgaard, J. P., Bald, C., \& Nord-Larsen, T. (2011). Functions for biomass and basic density of stem, crown and root system of Norway spruce (Picea abies (L.) Karst.) in Denmark. Scandinavian Journal of Forest Research, 26(11), 3-20. https://doi.org/10.1080/02827581.2011.564381

224. Smilga, J. (1967). Parastās apses koksnes tilpumsvars Latvijas PSR. JaunāKais Mežsaimniecībā , 9, 97-99.

225. Smilga, J. (1988). Apses koksnes blīvums. JaunāKais Mežsaimniecībāa, 30, 54-60.

226. Smith, A., Granhus, A., \& Astrup, R. (2016). Functions for estimating belowground and whole tree biomass of birch in Norway. Scandinavian Journal of Forest Research, 31(6), 568-582. https://doi.org/10.1080/02827581.2016.1141232

227. Smith, A., Granhus, A., Astrup, R., Bollandsås, O. M., \& Petersson, H. (2014). Functions for estimating aboveground biomass of birch in Norway. Scandinavian Journal of Forest Research, 29(6), 565-578. https://doi.org/10.1080/02827581.2014.951389

228. Smith, P., Powlson, D., Glendining, M., \& Smith, J. (1997). Potential for carbon sequestration in European soils: Preliminary estimates for five scenarios using results from long- $\square$ term experiments. Global Change Biology, (1997), 67-79. https://doi.org/10.1046/j.1365-2486.1997.00055.x 
229. Smyth, C. E., Kurz, W. A., Neilson, E. T., \& Stinson, G. (2013). National-scale estimates of forest root biomass carbon stocks and associated carbon fluxes in Canada. Global Biogeochemical Cycles, 27(4), 1262-1273. https://doi.org/10.1002/2012GB004536

230. Snowdon, P. (1991). A ratio estimator for bias correction in logarithmic regressions. Canadian Journal of Forest Research, 21, 720-724.

231. Somogyi, Z., Cienciala, E., Makipaa, R., Muukkonen, P., Lehtonen, A., \& Weiss, P. (2007). Indirect methods of large-scale forest biomass estimation. European Journal of Forest Research, 126(2), 197-207. https://doi.org/10.1007/s10342-006-0125-7

232. Stegen, J. C., Swenson, N. G., Enquist, B. J., White, E. P., Phillips, O. L., Jørgensen, P. M., ... Núñez Vargas, P. (2011). Variation in above-ground forest biomass across broad climatic gradients. Global Ecology and Biogeography, 20(5), 744-754. https://doi.org/10.1111/j.1466-8238.2010.00645.x

233. Stovall, A. E. L., Shugart, H. H., Stovall, A. E. L., Anderson-Teixeira, K. J., \& Anderson-Teixeira, K. J. (2018). Assessing terrestrial laser scanning for developing nondestructive biomass allometry. Forest Ecology and Management, 427, 217-229. https://doi.org/10.1016/j.foreco.2018.06.004

234. Temesgen, H., Affleck, D., Poudel, K., Gray, A., \& Sessions, J. (2015). A review of the challenges and opportunities in estimating above ground forest biomass using tree-level models. Scandinavian Journal of Forest Research, 30(4), 326-335. https://doi.org/10.1080/02827581.2015.1012114

235. Thenkabail, P. S., Stucky, N., Griscom, B. W., Ashton, M. S., Diels, J., Van der Meer, B., \& Enclona, E. (2004). Biomass estimations and carbon stock calculations in the oil palm plantations of African derived savannas using IKONOS data. International Journal of Remote Sensing, 25(23), 5447-5472. https://doi.org/10.1080/01431160412331291279

236. Thomas, S. C., \& Malczewski, G. (2007). Wood carbon content of tree species in Eastern China: Interspecific variability and the importance of the volatile fraction. Journal of Environmental Management, $\quad$ 85(3), 659-662. https://doi.org/10.1016/j.jenvman.2006.04.022

237. Thomas, S. C., \& Martin, A. R. (2012). Carbon content of tree tissues: A synthesis. Forests, 3(2), 332-352. https://doi.org/10.3390/f3020332

238. Thurner, M., Beer, C., Santoro, M., Carvalhais, N., Wutzler, T., Schepaschenko, D., ... Schmullius, C. (2014). Carbon stock and density of northern boreal and temperate forests. Global Ecology and Biogeography. https://doi.org/10.1111/geb.12125

239. Titlyanova, A. A., Romanova, I. P., Kosykh, N. P., \& Mironycheva-Tokareva, N. P. (1999). Pattern and process in above-ground and below-ground components of grassland ecosystems. Journal of Vegetation Science, 10(3), 307-320. https://doi.org/10.2307/3237060

240. Tomppo, E., Gschwantner, T., Lawrence, M., \& McRoberts. (2010). National Forest Inventories: Pathways for Common Reporting. Springer Netherlands. https://doi.org/10.1007/978-90-481-3233-1

241. UNFCCC. (2018). National Inventory Submissions 2018. Retrieved from http://unfccc.int/national_reports/annex_i_ghg_inventories/national_inventories_submissi ons/items/10116.php

242. Unger, N. (2014). Human land-use-driven reduction of forest volatiles cools global climate. Nature Climate Change, 4(10), 907-910. https://doi.org/10.1038/nclimate2347

243. Uri, V., Kukumägi, M., Aosaar, J., Varik, M., Becker, H., Morozov, G., \& Karoles, K. (2017). Ecosystems carbon budgets of differently aged downy birch stands growing on well-drained peatlands. Forest Ecology and Management, 399, 82-93. https://doi.org/10.1016/j.foreco.2017.05.023

244. Uri, V., Kukumägi, M., Aosaar, J., Varik, M., Becker, H., Soosaar, K., ... Karoles, K. (2017). Carbon budgets in fertile grey alder (Alnus incana (L.) Moench.) stands of different ages. Forest Ecology and Management, 396, 55-67. 
https://doi.org/10.1016/j.foreco.2017.04.004

245. Uusvaara, O., \& Pekkala, O. (1979). Technical properties of the wood and pulp of certain foreign and uncommon native tree species. Communicationes Instituti Forestalis Fenniae, 96(2), 1-59.

246. Vaglio Laurin, G., Chen, Q., Lindsell, J. A., Coomes, D. A., Frate, F. Del, Guerriero, L., ... Valentini, R. (2014). Above ground biomass estimation in an African tropical forest with lidar and hyperspectral data. ISPRS Journal of Photogrammetry and Remote Sensing, 89, 49-58. https://doi.org/10.1016/j.isprsjprs.2014.01.001

247. Vallet, P., Dhôte, J. F., Moguédec, G. Le, Ravart, M., \& Pignard, G. (2006). Development of total aboveground volume equations for seven important forest tree species in France. Forest Ecology and Management, 229(1-3), 98-110. https://doi.org/10.1016/j.foreco.2006.03.013

248. van der Werf, G. R., Morton, D. C., DeFries, R. S., Olivier, J. G. J., Kasibhatla, P. S., Jackson, R. B., ... Randerson, J. T. (2009). CO2 emissions from forest loss. Nature Geoscience, 2(11), 737-738. https://doi.org/10.1038/ngeo671

249. Varik, M., Aosaar, J., Ostonen, I., Lõhmus, K., \& Uri, V. (2013). Carbon and nitrogen accumulation in belowground tree biomass in a chronosequence of silver birch stands. Forest Ecology and Management, 302, 62-70. https://doi.org/10.1016/j.foreco.2013.03.033

250. Vogt, K. a, Vogt, D. J., \& Bloomfield, J. (1998). Analysis of some direct and indirect methods for estimating root biomass and production of forests at an ecosystem level. Plant and Soil, 200(1), 71-89. https://doi.org/10.1023/A:1004313515294

251. Wagenmakers, E.-J., \& Farrell, S. (2004). AIC model selection using Akaike weights. Psychonomic Bulletin and Review, 11, 192-196. https://doi.org/10.3758/BF03206482

252. Warner, B. G., Clymo, R. S., \& Tolonen, K. (1993). Implications of Peat Accumulation at Point Escuminac, New Brunswick. Quaternary Research, 39(2), 245-248. https://doi.org/10.1006/qres.1993.1028

253. Weiskittel, A. R., MacFarlane, D. W., Radtke, P. J., Affleck, D. L. R., Temesgen, H., Woodall, C. W., ... Coulston, J. W. (2015). A Call to Improve Methods for Estimating Tree Biomass for Regional and National Assessments. Journal of Forestry, 113(4), 414424. https://doi.org/10.5849/jof.14-091

254. Westerling, A. L. (2006). Warming and Earlier Spring Increase Western U.S. Forest Wildfire Activity. Science, 313(5789), 940-943. https://doi.org/10.1126/science.1128834

255. Wilhelmsson, L., Arlinger, J., Spångberg, K., Lundqvist, S.-O., Grahn, T., Hedenberg, Ö., \& Olsson, L. (2002). Models for Predicting Wood Properties in Stems of Picea abies and Pinus sylvestris in Sweden. Scandinavian Journal of Forest Research, 17(1975), 330-350. https://doi.org/10.1080/02827580260138080

256. Williamson, P., Wallace, D. W. R., Law, C. S., Boyd, P. W., Collos, Y., Croot, P., ... Vivian, C. (2012). Ocean fertilization for geoengineering: A review of effectiveness, environmental impacts and emerging governance. Process Safety and Environmental Protection, 90(6), 475-488. https://doi.org/10.1016/j.psep.2012.10.007

257. Wirth, C., Schumacher, J., \& Schulze, E. D. (2004). Generic biomass functions for Norway spruce in Central Europe-a meta-analysis approach toward prediction and uncertainty estimation. Tree Physiology, 24(2), 121-139. https://doi.org/10.1093/treephys/24.2.121

258. Worrall, J. J., \& Fairweather, M. L. (2009). Decay and Discoloration of Aspen. USDA Forest Service, (May), 1-12. Retrieved from http://www.fs.fed.us/r6/nr/fid/fidls/fidl2.pdf

259. Wosten, J. H. M., Ismail, A. B., \& VanWijk, A. L. M. (1997). Peat subsidence and its practical implications: A case study in Malaysia. GEODERMA, 78(1-2), 25-36. https://doi.org/10.1016/S0016-7061(97)00013-X

260. WRI. (2012). World GHG Emissions Flow Chart. World Resource Institute report. 
Retrieved from http://www.ecofys.com/files/files/world-ghg-emission-flow-chart2012_v9-c-asn-ecofys-2016_02.pdf

261. Xue, B.-L., Guo, Q., Hu, T., Wang, Y., Tao, S., Sun, Y., ... Zhao, X. (2017). Evaluation of modeled global carbon dynamics: analysis based on global carbon flux and aboveground biomass data. Ecological Modelling, 355, 84-96. https://doi.org/10.5194/bg2016-142

262. Yuan, Z. Y., \& Chen, H. Y. H. (2012). Indirect Methods Produce Higher Estimates of Fine Root Production and Turnover Rates than Direct Methods. PLoS ONE, 7(11). https://doi.org/10.1371/journal.pone.0048989

263. Zanne, A. E., Lopez-Gonzalez, G., Coomes, D. A. A., Ilic, J., Jansen, S., Lewis, S. L. S. L., ... Chave, J. (2009). Global wood density database. Dryad Digital Repository. https://doi.org/10.5061/dryad.234

264. Zeng, N. (2008). Carbon sequestration via wood burial. Carbon Balance and Management, 3(1), 1. https://doi.org/10.1186/1750-0680-3-1

265. Zhang, S. Y. (1995). Effect of growth rate on wood specific gravity and selected mechanical properties in individual species from distinct wood categories. Wood Science and Technology, 29(6), 451-465. https://doi.org/10.1007/BF00194204

266. Zianis, D., \& Mencuccini, M. (2004). On simplifying allometric analyses of forest biomass. Forest Ecology and Management, 187(2-3), 311-332. https://doi.org/10.1016/j.foreco.2003.07.007

267. Zianis, D., Muukkonen, P., Makipaa, R., \& Mencuccini, M. (2005). Biomass and stem volume equations for tree species in Europe. Silva Fennica Monographs, 4, 1-63.

268. Zobel, B. J., \& Jett, J. B. (1995). Genetics of wood production. Springer Verlag. https://doi.org/10.1007/978-3-642-79514-5 